\title{
Holocaust Museums at a Crossroads: Ethical Debates and Moral Obligations
}

Leah Angell Sievers

Midlothian, Virginia

B.A. Literature, Yale University, 1997

M.T.S. World Religions, Harvard Divinity School, 2001

A Dissertation presented to the Graduate Faculty

of the University of Virginia in Candidacy for the Degree of

Doctor of Philosophy

Department of Religious Studies

University of Virginia

October 4, 2013

Prof. Asher Biemann

Prof. Larry Bouchard

Prof. Gabriel Finder

Prof. Jennifer Geddes

Prof. Charles Mathewes 


\section{TABLE OF CONTENTS}

\section{Introduction}

Chapter One: Early Holocaust Memorial Practices

Life in the Displaced Persons Camps

Reestablishing a Sense of Jewish Life, Jewish Self, and Jewish Community

Documenting Survivor Testimonies in the Displaced Persons Camps

Post-War Immigration to the United States

Conclusion

\section{Chapter Two: Holocaust Remembrance in Israel and Germany}

Memorials, Monuments, and Museums

Yad Vashem

The Jewish Museum Berlin

Conclusion

Chapter Three: Holocaust Museums in the United States

Turning Points

The United States Holocaust Memorial Museum

The Los Angeles Museum of the Holocaust

The Illinois Holocaust Museum \& Education Center

Conclusion

\section{Chapter Four: Holocaust Uniqueness and Holocaust Memory}

The Uniqueness Debate

It's Jewish to Remember

The Memory Debate

Conclusion

Chapter Five: Engaging the Ethical and the Aesthetic

The Ethical Tasks of Holocaust Museums

Creating a Moral Museum

Ethical Dilemmas at the United States Holocaust Memorial Museum

How Museums Today Use Survivor Testimony

How Museums Today Address Contemporary Anti-Semitism

Conclusion

Chapter Six: United States Holocaust Museums and Twentieth-Century Genocide

The United States Holocaust Memorial Museum: From Memory to Action

The Los Angeles Museum of the Holocaust: Conflict Over Armenia

The Illinois Holocaust Museum \& Education Center: Remaining Relevant

Conclusion

Conclusions and Perspectives

Bibliography 


\begin{abstract}
My dissertation, "Holocaust Museums at a Crossroads: Ethical Debates and Moral Obligations," arises out of more than fifteen years of work experience in and study of Jewish and Holocaust museums and Jewish culture, traditions, literature, texts, philosophy, and ethics. The primary goal of my research is to argue that Holocaust museums are at a crossroads as they face the demise of the survivor population, the fact of ongoing genocide and mass atrocities, and the persistence of anti-Semitism and other forms of discrimination around the world. In this interest, the dissertation is not just about empirical evidence and curatorial decisions but also about analyzing museum practices through the lens of post-Holocaust Jewish moral thought.
\end{abstract}

This project is a normative one, and it articulates an ethical and philosophical framework against which museums' curatorial and philosophical choices can be examined. It fits into an unoccupied niche in the field of literature on the Holocaust and Holocaust museums by documenting and analyzing in extensive detail the way that Holocaust museums are filtering and/or prompting the key questions being faced in Holocaust institutions and by the Jewish community today. It examines three major issues: how museums address the subject of modern genocide, how they incorporate survivor testimony, and how — or whether — they present the fact of ongoing anti-Semitism. This work adds layers of specificity and focus to the dialogue on the relation of the Holocaust to other genocides and to an ethical understanding of Holocaust representation.

Methodologically, the project relies upon three specific approaches to assist me in answering questions such as the ones above. First, I employ empirical analysis as it has 
been developed in the field of cultural anthropology and engage in close examinations of three major Holocaust museums - the Los Angeles Museum of the Holocaust, the United States Holocaust Memorial Museum, and the Illinois Holocaust Museum and Education Center - through on-site visits, interviews with senior staff, a study of web materials, and close analysis of museum documents such as minutes from meetings and mission statements. The museums and their relevant documents function as primary source materials in my research.

The second approach is historical analysis, and the literature of the field is used as secondary source material that sheds light on the decisions made in the museums and on the history of their development. Finally, there is a philosophical analysis of the empirical and historical data and the patterns documented, employing various philosophical and ethical approaches to formulate an assessment of the future of Holocaust museums in the United States. Philosophical analysis functions here as both an interpretive tool and as a means by which to reflect on specific ethical questions and on the future direction of Holocaust museums. Through the use of these approaches, this dissertation responds to the significance of the issues raised here to the future of Holocaust museums. 


\section{INTRODUCTION}

This dissertation stems from more than fifteen years of my interest and professional involvement in museums, an interest that has grown through summer internships at the Smithsonian National Museum of American History in Washington, D.C. and the Skirball Cultural Center in Los Angeles and through my past employment at the Simon Wiesenthal Center Museum of Tolerance in Los Angeles and the Virginia Holocaust Museum in Richmond, Virginia. The subject of this dissertation therefore arises out of my professional experiences in museums and out of my academic work at the University of Virginia.

Empirically, I have observed in my professional experience and in recent research trips to museums such as the Museum of Tolerance, the Skirball Cultural Center, the Jewish Museum in New York, the Museum of Jewish Heritage: A Living Memorial to the Holocaust in New York, the Virginia Holocaust Museum, the Los Angeles Museum of the Holocaust, the Illinois Holocaust Museum \& Education Center, the 9/11 Memorial site, the Smithsonian National Museum of the American Indian, and the United States Holocaust Memorial Museum that museums vary widely in how they represent the traumatic past. Holocaust museums are no different, and they also diverge in how and to what degree they address two particular subjects: the fact that there have been genocides other than the Holocaust during the twentieth-century and the problem of resurgent antiSemitism. What Holocaust museums have in common is a deep concern about the future of the museums once there are no longer any living Holocaust survivors and a desire to stay relevant in an ever-changing world. 
As I became curious about these subjects and began my research, I found that the literature in the field of Holocaust Studies, Jewish Studies, Museum Studies, and Religious Studies on subjects ranging from museum theory to Holocaust remembrance to religious ethics did not address my questions about how museums were proposing to meet the challenge of a world without Holocaust survivors and why the museums vary in their approach to the subjects of modern genocide and resurgent anti-Semitism, though some scholars do go in these directions slightly. There were no major empirical studies of Holocaust museums' approaches to these issues to support my research. To be clear, there $i s$ an enormous amount of scholarly work in many of the subject areas on which this dissertation relies, such as Holocaust memory, ${ }^{1}$ ethics, ${ }^{2}$ representation, ${ }^{3}$ architecture, ${ }^{4}$ history, ${ }^{5}$ and museums. ${ }^{6}$ Scholars in these fields have made significant accomplishments in documenting subjects including but not limited to the development of "Jewish" and Holocaust architecture, Jewish theology after the Holocaust, post-Holocaust ethics, museums ethics, and Holocaust remembrance.

There is perhaps a gap in the literature in the areas mentioned above due to several influential factors. In regard to the subject of modern genocide, it bears noting that the United States Holocaust Memorial Museum in Washington, D.C. had extensive debates on the subject in its planning stages, which are well-chronicled in religious studies scholar Edward T. Linenthal's book on the museum, Preserving Memory, and in the museum's own records from the time. ${ }^{7}$ Given that the Holocaust Memorial Museum was the first major Holocaust museum built in the United States, its decisions set a precedent for the many Holocaust museums that were to follow, and its creation was closely followed in scholarly circles and in the media. As the first of its kind in this country, the 
museum's planning stages involved many serious, tense discussions that brought significant attention to the notion of museological ethics. All museums are in one way or another laboratories for ethical issues, but Holocaust museums bring specific ethical concerns - such as representation, memory, and Holocaust uniqueness - to the forefront regardless of whether those debates are as pressing today as they were when the first Holocaust museums were being built. The force of these ethical debates remains powerful today, especially as the memorial and geopolitical topography of the world continues to change. The basic code of museum ethics has stayed the same, but the subjects matter to which that code applies continues to evolve.

The American Alliance of Museums (AAM) asserts in its Code of Ethics that museums should consider themselves the stewards of the cultural wealth of a nation, prioritize the preservation of cultural heritage for posterity, be committed to public service, and acquire and maintain their collections lawfully and respectfully. ${ }^{8}$ The AAM also advocates that each member institution create its own code of ethics in addition to subscribing to the AAM code so that each museum can adjust the code to accommodate its own special needs, obligations, and concerns. In this dissertation, museological ethics should be understood to mean the museum best practices in which museums engage as they are determined by the museum's ethical code.

Chapter Five of this dissertation addresses in detail the specific ethical tasks of United States Holocaust museums as they grappled with how to practice and create, if need be, their institutional codes of ethics. As a result of the ethical precedent set in regard to the subject of modern genocide, however, and as this dissertation will attempt to show, only 
the Holocaust Memorial Museum had what can be called vociferous debates on the subject. The Los Angeles Museum and the Illinois museum devote differing amounts of exhibit space and narrative attention to modern genocide, and they address the subject without significant debate about whether to do so. Similarly, the creation of Holocaust museums after the Holocaust Memorial museum was not followed quite as closely; they were noted in local media, but no museum since has received the same level of attention as interest in the subject has waned. Despite the creation of several new Holocaust museums in the United States and abroad in the past decade and the release of countless books and films on the subject, there is less interest in the subject overall-even in the Jewish community. In regard to the subject of resurgent anti-Semitism, it is addressed tentatively if at all in the museums. In the United States, the subject of anti-Semitism falls under the purview of the Anti-Defamation League, so as this dissertation will try to demonstrate, Holocaust museums are leaving responsibility for addressing the subject to that organization. Finally, because there are still living Holocaust survivors actively involved in Holocaust museums, the notion of a world without them belongs more to speculation than to reality. That said, the loss of the survivors constitutes a major concern for Holocaust museum staff, and as such, their impending loss haunts discussions about the future of Holocaust museums pervasively. This dissertation thus aims to fill a gap in the literature in the relevant fields by providing empirical documentation and theoretical interpretation in these areas.

I first approached this task through extensive empirical research. I made multiple visits to each of the three museums on which this focuses - the Holocaust Memorial Museum, the Los Angeles Museum, and the Illinois museum—and had meetings and conversations 
with museum staff, docents, volunteers, and survivors. I worked from their libraries and archives where possible and relied heavily on my own field notes, engaging the principles of ethnography, anthropology, and museology in so doing. I also employed theoretical methodologies when situating the museums and their histories against the backdrop of the formative scholarly debates on Holocaust uniqueness and Holocaust memory, drawing on practices in the fields of religious studies and religious ethics that involve applying religious ethical principles to present-day problems. In addition, I have tried to follow the example of the scholarly work in Holocaust studies by writing sensitively and with respect for the victims and survivors of the Holocaust while prioritizing historical accuracy and careful attention to philosophical nuance.

My thesis, that Holocaust museums today are at a crossroads as they negotiate a future without survivors and a world rife with genocidal activity and resurgent anti-Semitism, includes several key points. The first point is that contrary to popular belief, there was not a complete silence about the Holocaust in the United States during the first few postwar decades. Instead, there emerged a wide range of Holocaust memorial practices and the development of a Holocaust museum in Israel, Yad Vashem. Second, I argue that Holocaust museums are anything but uniform in practice and appearance, a claim that I try support through detailed descriptions of Yad Vashem and the Berlin Jewish Museum and descriptive tours of the Holocaust Memorial Museum, the Los Angeles Museum, and the Illinois museum. I attempt to demonstrate that each of these museums has been built with a particular personality and is a reflection of its very specific cultural and ethical environment. Third, I strive to evoke the complexity of the museums' task of defining themselves by explicating the debates over the uniqueness of the Holocaust and 
Holocaust memory, the two major philosophical forces undergirding the creation of Holocaust museums. Fourth, I examine in detail the ethical tasks that Holocaust museums have confronted throughout their development, regardless of whether those tasks were as seemingly small as deciding whether to use a certain artifact or as large as deciding whether to acknowledge other genocides. Finally, I conclude by attempting to offer an ethical framework through which the future of Holocaust museums could be considered. Overall, I want to offer a study that connects the history of the emergence and struggle of Holocaust museums to applied ethics, examining how Holocaust museums function as moral institutions that occupy a special, prophetic place in American society; this study and its conclusions unfold in the pages that follow here.

\footnotetext{
${ }^{1}$ Holocaust memory may be one of the most thoroughly examined areas of Holocaust studies, and it is addressed in Chapter Four. The following list of formative works in the field is partial at best, but I have tried to name a number of them in the interest of providing a cross-section of the relevant texts in the field: Geoffrey Hartman's Holocaust Remembrance: The Shapes of Memory (Oxford and Cambridge: Blackwell, 1994); Berel Lang's The Future of the Holocaust: Between History and Memory (Ithaca and London: Cornell University Press, 1999); Jeffrey K. Olick, Vered Vinitzky-Seroussi, and Daniel Levy's The Collective Memory Reader (Oxford: Oxford University Press, 2011); and Michael Rossington and Anne Whitehead's Theories of Memory: A Reader (Baltimore: Johns Hopkins University Press, 2007).

${ }^{2}$ The notion of post-Holocaust ethics has seen much attention in the scholarly literature in the field. Influential texts include: Elliot N. Dorff and Louis E. Newman's Contemporary Jewish Ethics and Morality: A Reader (New York and Oxford: Oxford University Press, 1995); Jennifer L. Geddes, John K. Roth, and Jules Simon's The Double Binds of Ethics after the Holocaust: Salvaging the Fragments (New York: Palgrave Macmillian, 2009); Jakob Lothe, Susan Rubin Sulaiman, and James Phelan's After Testimony: The Ethics and Aesthetics of Holocaust Narratives for the Future (Columbus: Ohio State University Press, 2012); John K. Roth's Ethics After the Holocaust: Perspectives, Critiques, and Responses (St. Paul, Minnesota: Paragon House, 1999); and John K. Roth's Ethics During and After the Holocaust: In the Shadow of Birkenau (New York: Palgrave Macmillan; 2005).

${ }^{3}$ Major texts in the field of Holocaust representation include: Harold Kaplan's Conscience and Memory: Mediations in a Museum of the Holocaust (Chicago and
} 
London: University of Chicago Press, 1994); Berel Lang's Holocaust Representation: Art within the Limits of History and Ethics (Baltimore and London: Johns Hopkins University Press, 2000); Oren Baruch Stier's Committed to Memory: Cultural Mediations of the Holocaust (Amherst and Boston: University of Massachusetts Press, 2003); and Oren Baruch Stier and J. Shawn Landres's Religion, Violence, Memory, and Place (Bloomington \& Indianapolis: Indiana University Press, 2006).

${ }^{4}$ Gabriel D. Rosenfeld's recent book, Building After Auschwitz: Jewish Architecture and the Memory of the Holocaust (New Haven \& London: Yale University Press, 2011) is an authoritative chronicle of Jewish architecture and Holocaust museum architecture. Also influential are Brett Ashley Kaplan's Unwanted Beauty: Aesthetic Pleasure in Holocaust Representation (Urbana \& Chicago: University of Illinois Press, 2007); Daniel

Libeskind's The Space of Encounter (New York: Universe Publishing, 2000); and James E. Young's At Memory's Edge: After-Images of the Holocaust in Contemporary Art and Architecture (New Haven \& London: Yale University Press, 2000).

${ }^{5}$ The literature on the history of the Holocaust is vast, but the followings works are especially notable are: Michael Berenbaum and Abraham J. Peck's The Holocaust and History: The Known, the Unknown, the Disputed, and the Reexamined (Bloomington and Indianapolis: Indiana University Press, 1998); Christopher Browning's The Origins of the Final Solution: The Evolution of Nazi Jewish Policy, September 1939-March 1942 (Lincoln and Jerusalem: University of Nebraska Press and Yad Vashem, 2004); Sail Friedlander's The Years of Extermination: Nazi Germany and the Jews, 1939-1945 (New York: Harper Perennial, 2007); and Axis Rule in Occupied Europe: Laws of Occupation, Analysis of Government, Proposals for Redress (Clark, New Jersey: Lawbook Exchange, Ltd., 2008).

${ }^{6}$ The significant texts in the field of museum studies include but are not limited to Andreas Huyssen's Urban Palimpsests and the Politics of Memory (Stanford, California: Stanford University Press, 2003); Sharon MacDonald's The Politics of Display: Museums, Science, Culture (London \& New York: Routledge, 1998); Daniel J. Sherman and Irit Rogoff's MuseumCulture: Histories, Discourses, Spectacles (Minneapolis, Minnesota: University of Minnesota Press, 1994); and Paul Williams' Memorial Museums: The Global Rush to Commemorate Atrocities (Oxford \& New York: Berg, 2007). Edward T. Linenthal's Preserving Memory: The Struggle to Create America's Holocaust Museum (New York: Columbia University Press, 1995); James E. Young's The Texture of Memory: Holocaust Memorials and Meaning (New Haven \& London: Yale University Press, 1993) are formative work in the field.

${ }^{7}$ Edward T. Linenthal, Preserving Memory: The Struggle to Create America's Holocaust Museum (New York: Columbia University Press, 2005).

8 American Alliance of Museums, "Code of Ethics for Museums," accessed October 21, 2013, http://www.aam-us.org/resources/ethics-standards-and-best-practices/code-ofethics. 


\section{CHAPTER ONE: EARLY HOLOCAUST MEMORIAL PRACTICES}

This chapter intends to dispel two of the most widely perpetuated misperceptions about the Holocaust: that for twenty years after the war, the Jewish world remained silent about what had happened ${ }^{1}$ and that Holocaust survivors emerged from the war nothing but weak, fragile, and emotionally disabled. While many survivors did indeed face physical and emotional challenges after the war, many also possessed the energy and will necessary to effect remembrance and recovery under extremely difficult circumstances. The following chapter elucidates the vibrant memorial culture present in the European displaced persons (DP) camps in the years immediately following the Holocaust and traces the migration of that memorial culture to the United States when Holocaust survivors immigrated there.

The empirical phenomenon of memorial culture can be defined as the environment in which memorial practices surface and are effected in a given setting and as a result of circumstantial influences, but the concept of memorial culture has to do with the capacity of memory to function as both a means of storage and a means by which retrieval can occur, with the term culture here referring to the actual performance or enactment of memory. Today society commemorates the past through methods that range from the traditional placing of flowers on a grave to creating memorial websites to building memorial museums. This chapter sets out to describe the memorial practices that arose in post-war displaced persons camps and later in immigrant communities in the United States in order to demonstrate the way in which Holocaust survivors created a specific 
culture of remembrance in response to their circumstances. These memorial practiceswhich included but were not limited to the recording of survivor testimonies, the reinvigoration of traditional Jewish life, and the creation of memorial books — existed not just for the purpose of storing the memories or retrieving them. The postwar memorial culture came into existence for reasons that included the need to preserve Jewish culture that had been decimated during the Holocaust, the need to create memorial rituals that could serve as a bridge between the traumatic past, the present, and the future, and the need to rebuild Jewish life after the war.

Given that this dissertation chronicles the museological trajectory of Holocaust remembrance in the United States, it bears noting here that the existence of a postHolocaust memorial culture in Europe and in the United States does not in and of itself lay the foundation for the development of Holocaust museums. In other words, memorial practice does not inherently lead to the creation of museums per se. In fact, as this chapter will demonstrate, the memorial practices of the first postwar decades were not museological at all; that is, they were not created or performed with museological intentions. Chronicling the memorial culture of the postwar years demonstrates not the early stages of museum culture but instead the early stages of a decades-long struggle to define and understand the relationship between history and memory in post-Holocaust Jewish life and culture. Holocaust museums emerged out of this struggle, not necessarily out of the memorial practices in the DP camps or in postwar United States. Even so, the memorial practices remain significant actors in the story of how Holocaust museums came into existence because they ultimately proved to be collectively insufficient in one 
regard: none of them could instantiate thoroughly, effectively, and concretely enough the tension between history and memory that so thoroughly preoccupied Holocaust survivors and Jews worldwide after the war. This chapter documents these practices in order to demonstrate that profound efforts at postwar Holocaust memorialization did exist immediately, without hesitation, and mostly significantly, in pursuit of permanent memorialization.

\section{Life in the Displaced Persons Camps}

In the days and weeks immediately following the end of World War II and the liberation of the concentration camps, Holocaust survivors either entered displaced persons camps, tried — often unsuccessfully — to return home, or immigrated to Palestine, certain parts of Europe, and the United States. Allied troops in Europe and Eastern Europe "faced the staggering problem of dealing with over [seven] million displaced persons in the occupied territories."2 Among them were hundreds of thousands of Jewish Holocaust survivors, who emerged from the camps, from partisan groups, and from hiding, deeply scarred emotionally and physically. At this time, however, they were only known as “displaced persons," not as "Holocaust survivors," for the term "Holocaust" had not yet been determined. ${ }^{3}$ They had lost countless family members, were far from home, and suffered from illness, disease, and starvation. As word of the horrors that had been found in the camps began to trickle back to the United States, many American Jews wanted to help. They felt "morally bound to lead and finance the work of rehabilitation and resettlement" of the survivors, their coreligionists. ${ }^{4}$ 
At the same time, many Americans - government officials included-had difficulty believing the reports that they were hearing. ${ }^{5}$ In the summer of 1945 , at the insistence of American Jewish leaders, President Truman agreed to send Earl Harrison, the American envoy to the Inter-Governmental Committee on Refugees, to investigate over thirty displaced persons camps. In June of 1945, “during a summer in which most Americans celebrated the war's end, Harrison and his associates...[discovered] that the unsubstantiated accounts were in fact understatements of the truth." ${ }^{6}$ The ensuing "Harrison Report" led to better living conditions for the displaced persons, the separation of Jews and non-Jews, and ultimately to President Truman's a posteriori attempts to persuade the British to allow more Jews into Palestine, which at the time was under British control and as such offered limited immigration possibilities for Jews trying to leave the displaced persons camps. ${ }^{7}$

In the interim, however, Jewish displaced persons and refugees from other cultural and national groups such as Poles, Ukranians, Latvians, Lithuanians, Estonians, and Yugoslavs, were living together in DP camps in Germany, Austria, and Italy. To further complicate matters, at first Jewish DPs were not separated from German or Polish refugees or given any more food or medical care even though they had suffered significantly worse fates during wartime, ${ }^{8}$ and the Allied soldiers who were supposedly there to help them "often showed little awareness of what survivors had been through or of their resulting state of mind," thereby participating in what was an inhospitable and uncomfortable environment for Jews. In addition, not separating the Jewish DPs from the Germans or Poles meant that Jews were living side-by-side with the very people who 
had turned against them or even perpetrated crimes against them during the war, especially given that sectarian organizations such as the American Jewish Joint Distribution Committee (AJJDC) ${ }^{10}$ — that were more sensitive to survivors' needs—-were not even permitted to enter the DP camps until August of $1945,{ }^{11}$ months after they had been established. ${ }^{12}$

Eventually this situation resolved, as Jews were given separate areas of the DP camps in which to live, the necessary medical attention, and food. The DP camps were more than way stations for recovery, however $;^{13}$ they were microcosms of Jewish tradition, language, and practice that could not be fully replicated when survivors later resettled far from their homelands. As this chapter will demonstrate, they became a living memorial to a culture that had been largely obliterated during the Holocaust. The historian Ruth Gay writes that "with substantial populations sometimes reaching 7,000 or 8,000 , the displaced persons camps became Jewish villages where for the last time Yiddish was still a working language...[The DP camps constituted] a brilliant flicker of life before the culture of Polish Jews disappeared," for the eventual mass immigration to Israel and the United States "ended this incandescent final moment of Eastern European Jewish life."

As survivors settled into their new lives in the DP camps and their health returned, they began to create this "living memorial." The tasks of reestablishing a sense of Jewishness and Jewish community, figuring out whether family members were still alive, deciding where to live more permanently, and finding jobs proved to be of paramount importance to the displaced Jews. It was in pursuit of these goals that Jewish Holocaust survivors 
demonstrated extraordinary resilience, fortitude, and the "implacable will" 15 mentioned at the outset of this chapter and began to establish what became the memorial culture of the postwar era. ${ }^{16}$ Forever under the shadow of remembrance, survivors worked to create a sense of normalcy in the DP camps by - as the next section of this chapter explainsstarting families and establishing schools. A baby named in memory of a loved one was no longer just that; he was a baby named for a loved one who had died too soon and during the Holocaust. A school was no longer just a school; it was a place built in order to reclaim the past, to begin again education that anti-Jewish legislation had halted years earlier, and to live out the Jewish value placed on learning that could no longer be fulfilled by the deceased.

\section{Reestablishing a Sense of Jewish Life, Jewish Self, and Jewish Community}

In her January 2000 talk at the United States Holocaust Memorial Museum's conference on Jewish Displaced Persons, "Coping with the Psychological Aftermath of Extreme Trauma," psychologist and Second Generation Advisory Group member Eva Fogelman explains in great detail the "unimaginable dissolution of the self" Jewish Holocaust survivors as a result of their experiences during the war. While this dissolution of the self certainly lended itself to terrible psychological aftereffects and long-term psychological difficulties that did begin to surface in the DP camps, the camps ironically also served as places where Jews tried to recover and rebuild from this loss of self and loss of community. In the DP camps, Jews from across Europe were together, and they were able to form a Jewish community from this admixture of Jewish people 
and Jewish ways. They created community by reviving Jewish religious traditions such as the Yizkor, or memorial, services traditionally recited on four memorial occasions during the Jewish year. Holding memorial services and saying the mourner's kaddish, part of Jewish liturgy said to honor those who are no longer living, helped Jewish DPsregardless of their level of observance prior to the war- to connect their new lives to the memories of those they had lost and to the pre-war worlds that they had left and would never fully recover. ${ }^{18}$ In the DP camp at Bergen-Belsen, there was a special ceremony commemorating the camp's April 15 Liberation Day anniversary, and on its first anniversary, the camp's Central Committee even erected a "Jewish monument" to mark the occasion. ${ }^{19}$ As the historian Gabriel N. Finder explains in his essay, "Yizkor! Commemoration of the Dead by Jewish Displaced Persons in Postwar Germany," these forms of memorialization not only channeled survivors' grief but also “integrated mourning into a political argument for the right of immigration to Jewish Palestine or, after 1948, to Israel." ${ }^{20}$ While many survivors did prefer to go to the United States and ultimately immigrated there, they all participated in the exuberant, active Zionism of the DP camps and shared the opinion that the Holocaust could have been "averted or at least diminished in scale" if the state of Israel had existed prior to the start of the war. ${ }^{21}$

Zionist beliefs and memorial services, however, were far from being the only memorial activities in which Jewish Holocaust survivors engaged in the DP camps. Jews from diverse backgrounds also united to mark each other's life cycle events, especially marriages, births, and deaths, which helped to cement Jewish collective identity in the DP camps. Liberators of the concentration camps did not understand Jewish burial rituals 
and traditions, often burying bodies in mass graves as a way to manage the sheer number of bodies and to reduce the spread of disease. For Jewish survivors, though, giving the dead dignified burials was the beginning of the process of reestablishing normative Jewish life after the war and memorializing in a specifically Jewish way.

Unfortunately, yet another tragedy occurred immediately after the liberation that precipitated the need for many more burials: there were many deaths due to illness and especially due to liberators' supplying too much food too quickly to survivors whose starved bodies were no longer equipped to digest food properly. ${ }^{22}$ As the numbers of bodies climbed into the thousands, Jewish DPs formed burial societies because "the reassertion of the dignity of the dead was a source of pride for the living," and "the ability to perform the essential tasks of Jewish burial symbolized the continual expression of Jewish values and community." ${ }^{, 23}$ The burial societies also oversaw the delicate and problematic task of arguing for and bringing to effect the reinterring of Jewish bodies that had been buried improperly at first. ${ }^{24}$ Although reinterring a body is generally not a supported or recommended practice in Judaism, under these extreme circumstances in the DP camps and amidst the extraordinary need for memorial practices, "Rabbi Ephraim Oshry of Kovno [Lithuania] ruled that whoever moved the body of a Holocaust victim to a Jewish cemetery did so for the deceased's honor and therefore performed a great service. ${ }^{, 25}$ Indeed, though the reinterring involved on one occasion a procession of coffins adorned with wreaths and flags down a street lined with people - again violating the Jewish tradition of the modest burial — the notion was that the processional sent a 
message to the Germans, that "these were the bodies of dignified and innocent people, worthy of honor"26 in life and in death.

In addition to reclaiming burial rites and honoring the dead through traditional ceremonies and prayers, Jewish DPs also sought to reclaim, recreate, and memorialize prewar Jewish community life by marrying and having children. Even Jews who were struggling to find faith in God and in humankind and who were devastated to be getting married without the presence of their parents and other loved ones did so as a way to honor their Jewish upbringing and to preserve its legacy. In his book about Holocaust survivors in the United States, social scientist William Helmreich writes that "of all the activities engaged in by survivors after the war...nothing required a commitment as great as that of marrying and having children... Marriage and children demanded that one genuinely give of oneself to others. They generally involved caring, trust, and love, thus giving survivors the opportunity to experience again positive emotions and to feel bound to others and to a community after years of upheaval and trauma. The weddings helped to anchor Jewish life in the DP camps, creating a positive cycle: the building of mikvaot for brides and married women; the need for ritual circumcisions; and the need for yeshivas as the couples' children grew older. For married Jewish DPs, then, having children became a "civic responsibility, ${ }^{, 28}$ a way to rebuild and reassert Jewish $\operatorname{life}^{29}$ and honor the dead — tasks with a clear moral overtone and purpose. Survivors had children in order to "replace those who were lost" and because of the "belief that having children proved that Hitler's grand design ultimately failed," so they tended to have large families; 
the displaced persons camps had "the highest birth rate of any Jewish community in the world. $" 30$

In addition to their traditional role as the bearers of these children and as wives, women played a primary role in the reestablishment of Jewish community life in the DP camps, as teachers and in less traditional professional roles. ${ }^{31}$ By the time the Holocaust ended, women were arguably accustomed to playing leadership roles in the family that were different from women's more customary roles in the home. Even prior to and during the early years of the Holocaust, wartime placed unusual demands on women and caused a significant amount of upheaval to typically patriarchal Jewish family life. When antiJewish legislation prohibited Jewish men from working, women needed to find ways to bring in income. Later, when the Nazis began to deport Jewish men, the men fled, went into hiding, were deported outright, or even were killed. In their absence, Jewish women not only continued to bear responsibility for their children, for the management of the household, and for the keeping of Jewish traditions and pratices but also to take over many of the men's responsibilities. This shift from the patriarchal to matriarchal structuring of families marked a major transition in Jewish culture and also a disintegration of traditional Jewish family life. By the time Jewish women found themselves in the DP camps, they had already experienced a profound degree of familial dissolution and a radical reshaping of their traditional roles - a reshaping that prepared them for their postwar roles as the rebuilders of the Jewish nuclear family and of Jewish practice. 
The desire to reshape, remember, rebuild, and return to a more normative familial life after years of upheaval lay behind the surge in weddings and births in the DP camps, where weddings occurred almost daily. Even women who were not married participated in the restructuring of Jewish family life, for they often worked as "foster mothers" or "mothers' helpers," assisting women with tasks such as standing in line for food or cleaning the living quarters - both of which tasks were time-consuming and tiring. Women also became trained as teachers, seamstresses, and nurses even if they had no prior experiences in these areas. They received training for these jobs immediately and enjoyed the benefits of earning money, learning a new occupation, and participating in a more social existence than they had had in years.

Still other women did take on the less traditional roles of religious leaders and political activists. In the DP camp at Bergen-Belsen, Orthodox Jewish women set up a kosher kitchen and organized to demand that kosher food be provided for it. They set up a sewing workshop to teach young Jewish women skills and to support Orthodox Jewish men, who were studying in yeshiva. They also schooled Jewish women in Orthodox Jewish traditions and practices and tried to prepare them thoroughly for an observant Jewish life in Palestine. In performing these less traditional roles, Jewish women revived key components of traditional Jewish religious life and in so doing honored the dead, whose lives, culture, beliefs, and heritage perished with them.

On the political front, women became involved in the different agencies and groups that formed in the DP camps. There were three women amongst the eight founders of the 
Central Historical Commission of the Central Committee of the Liberated Jews in the U.S. Zone. ${ }^{32}$ Many women were leaders in Zionist organizations and worked as instructors of the domestic arts in the vocational schools that the United Nations Relief and Rehabilitation Administration (UNRAA) and the Jewish relief agencies established. Several thousand women were volunteers for the Haganah, the Jewish Defense Forces. Overall, women were committed to ensuring that the DP camps functioned as selfsufficient units so that their hard work did not go toward German recovery efforts, so that they could shape the reestablishment of Jewish community life according to their preferences and standards, and so that they could ensure that they and their children would be as fully prepared as possible for resettlement in Palestine.

In addition to honoring life cycle events and renewing and creating memorial practices, Jewish DPs attempted to recreate a semblance of Jewish life in the DP camps by establishing schools. Yehuda Bauer writes that "in 1945-1946, under the most daunting circumstances, but driven by the typically Jewish urge to provide education for children and young people, schools were established in the DP countries." ${ }^{" 33}$ These "daunting circumstances" included an enormous lack of qualified teachers, as the Nazis had murdered many teachers, scholars, and intellectuals. Any teacher who remained had not been in a classroom in more than six years, since the war began, and any surviving child had similarly gone unschooled. American agencies such as the JDC (Joint Distribution Committee) "invested a great deal of effort" toward the project of creating the schools, thereby enabling Jewish life and Jewish education to begin to take its familiar place again in Jewish society despite the upheaval and challenging conditions. 
Jews in the displaced persons camps also created newspapers, political groups, ${ }^{34}$ cultural activities, ${ }^{35}$ professional opportunities, and even a "framework for Jewish selfgovernment." ${ }^{, 36}$ While these activities might not appear to be memorial activities in the way that burials or religious services are, it can be said that most efforts to recreate essential components of prewar life - even something as simple as a newspaper or a concert - were in fact memorial. They were memorial because after the Holocaust, that which was normative before the war-which had become non-normative during the war- had to be reclaimed. Even the most basic elements of human life such as eating regular meals and having children were almost obliterated during the Holocaust, so the redefinition of normativity in the DP camps meant treating what was once normative as an artifact, an object from the past that was used in the present to evoke the past and all that is connected to it: the people, the places, and their memory.

\section{Documenting Survivor Testimonies in the Displaced Persons Camps}

Documenting survivors' stories was another way that Jewish DPs tried to reassert the integrity and dignity of Jewish life after the war while remembering the dead, with the primary goals of the documentation also being to tell the story of the Holocaust, prosecute Nazi and other criminals, and provide therapeutic measures to survivors. ${ }^{37}$ The primary way that survivors documented this history was through the creation of a Historical Commission $^{38}$ that was headquartered in Munich, where it archived over thirtyfive hundred testimonies and more than one thousand photographs. ${ }^{39}$ The Historical 
Commission — and others like it in other parts of Germany and Europe — was a key component of the She'erit Hapletah or "Surviving Remnant," a group of stateless Jewish DPs that united and "emerged over several years a new and self-conscious Jewish collectivity" that "publicly identified as survivors of Nazi extermination plans [and who were] committed to Zionism and Jewish identity. ${ }^{, 40}$ In collecting eyewitness testimonies from survivors in the DP camps, the Historical Commission constituted the first attempts $^{41}$ to record the history of the Holocaust from a postwar Jewish perspective, laid the groundwork for future research on the Holocaust, and set a precedent for how Jewish survivors "encountered their traumatic past and integrated its lessons in their present and future lives. ${ }^{, 42}$

Jewish DPs in the British Zone of occupied Germany founded the first Historical Commission on October 10,1945, at which time a partisan group called the Palkakh was documenting the histories of the partisan groups. The DPs felt strongly that their stories should also be collected and remembered. ${ }^{43}$ The Historical Commissions sought to collect as much data as they could, ${ }^{44}$ though some members of the Commission placed more emphasis on the task for the purpose of historical scholarship while others emphasized instead the use of the material for bringing perpetrators to justice. Other significant reasons for performing the work of the Commissions include that the testimonies later helped make claims for material compensation and strengthened Jews' legal position. Their work also helped appeal to what Holocaust survivor and Nazi hunter Simon Wiesenthal called "the conscience of the world," 
no uncertain terms of the atrocities perpetrated against the Jews during the Holocaust.

Similarly Rabbi, professor, and Talmudic scholar Boaz Cohen explains that

it quickly became clear to Jewish observers that coming to terms with the Holocaust was not a priority in a postwar world. Early Cold-War Considerations entailed the downplaying of German atrocities. The victors of World War Two appeared unable or unwilling to understand the scope or significance of the Holocaust. Many Jews felt a sense of responsibility for bringing the details of the tragedy to light. ${ }^{46}$

It is from this impetus to record and inform in light of widespread disinterest that Jews around the world prioritized the recording of survivor testimony, even the testimony of child survivors. The Historical Commissions saw their work as "holy work" or as a "holy task" that they had been called to fulfill. There was a distinct sense of moral obligation to capture survivors' stories and record them in perpetuity, what scholar of modern German Studies Beate Muller calls a "moral investment in witnessing." ${ }^{47}$ The members of the Commissions "used a rhetoric of duty...in which they began to understand their survival as not merely accidental but as having bestowed upon them a moral imperative to bear witness, document, and testify" ${ }^{38}$ and to, as a result, later disprove the notion that after the war survivors spoke little about the Holocaust. Collecting testimony was not just a historical endeavor but also a moral and memorial one.

It was with this urgent sense of moral responsibility and with this idea of completing holy work that the Historical Commissions pursued their arduous and difficult work, for it was not always an easy task to gather survivors' stories. At first, when Jewish DPs were only mere days or weeks from liberation, they were centrally located and anxious to talk about 
their experiences. After time passed, however, difficulties arose. Some survivors were willing to tell their stories but did not necessarily want to cooperate with the Historical Commission, seeing no need to formalize the process of recording the information in such an analytical and methodical way. In addition, giving testimony created a psychological burden for survivors, as it asked them to revisit terrible memories. Many survivors did not think that their stories were important, or they did not understand the significance of testimony collection as an historical or academic endeavor. Finally, few members of the Commissions were actually trained historians, so many were inexperienced at the tasks of gleaning and organizing information in the ways necessary for collecting the stories properly.

Despite all of these challenges, the Historical Commissions worked hard to surmount the difficulties that they confronted, appealing to survivors in as many ways as possible. ${ }^{49}$ They promised honors and awards for giving testimony, and they also designed questionnaires as another way to help survivors feel comfortable communicating about the past other than through pure oral testimony. ${ }^{50}$ The questionnaires included "statistical" questionnaires on topics such as forced labor, corporal punishment, and medical experiments performed in the camps. "Historical" questionnaires asked broader questions about life under Nazi rule, imprisonment, hiding, and revolt. There were also "Folklore" questionnaires designed to gather ethnographic information and "postwar" questionnaires on Jewish DPs' postwar experiences. ${ }^{51}$ The DP Historical Commission published the survivors' testimonies in a ten-volume journal and made a special effort to publish children's testimonies in a Holocaust research journal entitled Fun Lesten Hurbn, 
or "From the Last Extermination. ${ }^{, 52}$ In 1947, the work of the Historical Commissions led to the Polish Jewish community in Lublin's creating a publishing company called Yiddish Bukh, an endeavor that had begun in 1945 and had prospered in part because the effort received money from American Jewish resources, both directly and indirectly. ${ }^{53}$ The Historical Commissions even presented the idea of placing artifacts that they had collected from survivors into exhibitions in a "museum-archive," an idea that took the form of a small exhibit in Munich on January 27, 1946 for a meeting of the First Congress of the She'erit Hapletah ${ }^{54}$ but it was almost ten years later before the idea of creating a museum about the Holocaust came to fruition in Israel at Yad Vashem, the Israeli Holocaust museum, which will be discussed in greater detail in Chapter Two.

\section{Post-War Immigration to the United States}

As mentioned earlier, after the war Jewish refugees who did not enter the DP camps immigrated primarily to Palestine, certain parts of Europe, and the United States. Of those survivors who were in the DP camps, roughly two-thirds immigrated to Israel and one-third to the United States. ${ }^{55}$ Survivors who went to the United States chose America over Israel for a variety of reasons: they wanted to reunite with family members there; they did not want to be pioneers in a difficult land after enduring years of hardship during the Holocaust; they felt that they could "fit into" American society and create new lives there; and they were not ultimately as committed to Zionism as other survivors. ${ }^{56}$ As a result, immigration to the United States became a typical path for a Holocaust survivor: while in 1928 there were 4,200,000 Jews living in America, by the end of 1945 there were five million. ${ }^{57}$ 
Once in America, Jewish refugees began the process of reconnecting with relatives, finding jobs, and finding places to live. They "settled wherever they had friends or relatives already established in America, or wherever the Jewish social agencies that had brought them from Europe had found sponsors for them," ${ }^{, 58}$ though they did gravitate toward major urban centers such as New York or Chicago and soon toward "sun belt" cities such as Miami, Houston, and Los Angeles. ${ }^{59}$ Hovering over all of this resettlement activity was a layer of deep concern about the degree to which Jewish refugees would be welcome in their new communities, for "thoughtful Christians as well as Jews [were] aware of the threat to the world's peace and security implicit in any resurgence of antiSemitism. ${ }^{\prime 60}$ Despite finding a certain amount of freedom and relief in America, Jewish refugees remained concerned about anti-Semitism, which they knew to exist in the United States even thought it had never reached the level of virulence that it had in Eastern Europe during the Nazi era.

American Jews and Jewish refugees clung to the triad of culture, education, and religion as a way to strengthen and affirm their place in American society while memorializing the Jewish culture, Jewish learning, and Jewish practices that had perished during the Holocaust along with the millions. The historian Ruth Gay explains that Jews already in America "suddenly realized that they had inherited an awesome responsibility...the responsibility for remembering, for preserving East European Jewish language and culture," adding that "the reclamation of that past has grown into one of the guiding passions of the American Jewish community." ${ }^{, 61}$ This dissertation will demonstrate in 
future chapters one way in which this commitment to reclaiming the past has been effected in the United States.

Professor of American Jewish history Jonathan Sarna argues that the United States was already a home for active Jewish life even before the United States entered World War II. He writes, "American Judaism had actually been gaining strength since the late 1930s, partly, we have seen, as a form of spiritual resistance to Nazism and anti-semitism. Now with the war over, the nation as a whole turned increasingly toward religion-a response, some believed, to wartime horrors and to the postwar threat from 'godless' Communism." ${ }^{\prime 62}$ Jews were thus able to fit more comfortably into an American religious culture that soon recognized Judaism as its “"third faith' alongside Protestantism and Catholicism," and at the same time, Holocaust survivors" "memories, commitments, and collective sense of obligation to those who had not survived set the stage for developments that would transform all of American Judaism...for decades to come." ${ }^{, 63}$ The combined effect of Judaism's being accepted into American society as a mainstream religion and survivors' sense of moral responsibility to the memory of the deceased laid the groundwork for the future of Holocaust remembrance in the United States. There was a certain receptivity to Jews and Judaism in America not just because of Holocaust survivors' dedication but also because, as mentioned, American Jews felt responsible to the refugees. They felt responsible not just because they were Jewish but also because many had also lost relatives in the Holocaust and because there was a certain amount of guilt that they had not "done enough" to help their fellow Jews abroad during the war. ${ }^{64}$ American Jews thus assumed primary responsibility for the rehabilitation of Jewish 
refugees, giving large sums of money to organizations such as the Anti-Defamation League, the Simon Wiesenthal Center, and other organizations that fought antiSemitism ${ }^{65}$ in an effort to rebuild, memorialize, and prevent further violence. To this end, in the years from 1945-1948 American Jews donated \$50 million dollars per year to the American Jewish Joint Distribution Committee in support of its efforts at providing humanitarian aid to Jews in need. ${ }^{66}$

In addition to this financial commitment, there also emerged a philosophical commitment to examining the place and role of Judaism in America after the war and the establishment of new types of Jewish communities. During the 1950s, serious scholars such as A.J. Heschel and Abba Hillel Silver in the United States and Leo Baeck in Europe gave careful thought to the nature of Judaism in America at that time in their work in Jewish theology; their attention to the subject thus signified that an "American Jewish religious revival was under way" in the academy. ${ }^{67}$ The 1950s also saw many Jewish families move from the cities to the suburbs, especially young middle-class families, who "retained their prewar residential patterns of living in close proximity [to other Jews], but they did so by abandoning urban life en masse., ${ }^{, 68}$ Abandoning urban life meant trading apartment-building living and close proximity to the synagogue for single-family, widely spaced homes and the need to drive to communal spaces. There was also a high degree of transiency in these suburban communities, which made integration and the establishment of roots more difficult, especially for Jewish religious leaders trying to create permanent religious communities in the suburbs. ${ }^{69}$ As a result, the previous intimacy of Jewish urban communities began to dissolve, as did Jewish 
communities' resemblance to their Eastern European communities. This semblance of prewar life also deteriorated when Jews migrated west and south, where the topography, climate, and suburban lifestyle were all vastly different than both European Jewish communities and urban immigrant communities in the United States. By the end of the 1950s, almost 400,000 Jews lived in Los Angeles, about eighteen percent of the city's total population, and by 1955 , the Jewish population of Miami swelled from 16,000 in 1945 to $100,000 .^{70}$ Most Jews who moved to Los Angeles were young and in search of job opportunities, but they also wanted to establish voluntary communities of their Jewish peers who came from the same cities and towns. As a result, "by the early 1950s, several dozen...social clubs organized around city of origin flourished in Los Angeles," while at the same time other Jewish social groups such as B'nai B'rith, Hadassah, and the American Jewish Congress added thousands of new members to their rosters, demonstrating the burgeoning interest in Jewish community life even though that life looked vastly different than it had even ten years before. ${ }^{71}$

Another type of Jewish community organization, the landsmanschaftn or mutual aid societies of Jewish immigrants to the United States that existed even before the war, also emerged in America at the time. The precursor to the landsmanschaftn occurred in the DP camps, as survivors organized themselves into groups according to which town in Eastern Europe they had inhabited before the war in order to create community and record their towns' histories in yizker-bikher, or memorial books. ${ }^{72}$ One such group, survivors from Zhirardover, Poland, began to gather materials on the history of the town and its demise while its survivors were still in the DP camps - a memorial impulse that 
intensified and became widespread amongst survivors once they had immigrated to the United States. Landsmanschaftn in the United States helped survivors immigrate to and settle in the United States, and they "remained essentially centers of secular ethnic sociability, anchoring their members in unfamiliar urban territory through nostalgic evocations of the well-known world that had been abandoned." 73 Once this task had been completed, they focused on memorializing the dead from their community. They organized gatherings to be held each year on the anniversary of liquidation of their town's ghetto, set up communal tombstones, and established centers designed specifically for memorial and communal purposes. Most significantly, they continued to create the memorial books, thereby documenting Jewish life, culture, and history in a sensitive and detailed way.

The memorial books had a unifying effect for Jews, for unlike the more international, site-specific centers and tombstones, survivors from each town could have equal access to the memorial books regardless of where they had resettled after the war. As the anthropologist Jack Kugelmass and the scholar of modern Jewish thought Jonathan Boyarin write, "the yizker-bikher made it possible for the now widely dispersed survivors and émigrés to have a single memorial nearby. Such memorials did not supercede local efforts at commemoration; they bound communities together, recreating on paper the community of the past." ${ }^{, 4}$ As part of this attempt to recreate their communities on paper, the yizker-bikher were made to include maps, pictures, photographs, and even lists of the names of every person who lived in the town. As Judaic Studies scholar James Young explains, "for a murdered people without graves, without even corpses to inter, these 
memorial books often came to serve as symbolic tombstones." ${ }^{, 75}$ The books offer descriptions of the various buildings, homes, and institutions in the towns, as well as reports about the "erasure of Jewish memory" not just due to the inevitable ravages of time but also through non-Jewish residents' "appropriation" of Jewish structures and Jewish cemeteries once Jews no longer lived in the town.

It is against this appropriation and erasure that the memorial books were written, but they are also significant because they serve as yet another example of the widespread, vigorous Jewish memorial activity that was taking place in the DP camps and in Europe, Israel, and the United States in the years following the Holocaust. ${ }^{76}$ The yizker-bikher have their own precedent in the rich tradition of Jewish mourning literature and in the emergence of modern Yiddish literature that now takes on the particular form of the yizker-bikher since, because of, and in light of the Holocaust. They were written so that the generations to come would know of these communities in perpetuity. Though the intention is noble - that the yizker-bikher serve as a record of history—-they rely upon an audience that is literate in Yiddish in order to be effective conduits of history and memory. Sadly this audience no longer exists, with the rare exception of certain scholars in the field or the very elderly from Yiddish-speaking backgrounds. With each generation removed from those who survived the Holocaust, fewer and fewer people speak and read Yiddish, relegating the yizker-bikher to dusty shelves and distant memory.

\section{Conclusion}


As Holocaust scholar Zeev Mankowitz explains in his book about DP camps in Germany ${ }^{77}$ recovering from the traumatic experiences that they had had during the Holocaust was more difficult than many survivors had anticipated. Much as they would have liked to put the memory of such terrible experiences behind them, this proved to be an impossible task even though many survivors were leading productive lives in the DP camps and engaging in any number of memorial practices. Instead of being overcome by grief and anger, survivors channeled their emotions into rebuilding and largely into the task of remembering the dead. ${ }^{78}$ They felt a deep sense of obligation to the victims of the Holocaust and felt that they "owed" them remembrance and the living of "worthy lives."

Given that, at least at first, the rest of the world did not share survivors' grief or their concerns, Holocaust memorial practice did not extend much beyond the Jewish community. One example of the general lack of interest arose in regard to the creation of a day of remembrance. To meet their sense of obligation, survivors in the DP camps created an official "Day of Remembrance and Victory," the fourteenth day of Iyar, which fell on May 15 in 1946. On this day, they sang Hatikvah - the Israeli national anthem, said memorial prayers, stood in silent remembrance, laid wreaths on memorial tablets, lit memorial candles, flew Zionist and American flags, and used the slogan "Am Yisrael Chai" or "The People of Israel Are Alive" - thereby translating their memories into a political argument. While the Day of Remembrance and Victory was meaningful in the DP camps, the concept of a memorial "day" to the Holocaust was not as well-received in the wider Jewish community because Jews around the world were still struggling to understand the Holocaust and were only beginning to ask questions or learn about it. 
Since the end of the war, the DPs had been contemplating the question of how to balance their sense of obligation to the dead with their need to affirm the living, but Jews abroad who were not immigrants had not yet begun to examine this tension even though they felt guilty and gave money to help refugees, as explained earlier. It became clear that no amount of memorial books, memorial services, and memorial activities could accomplish the tripartite goal of memorializing the dead, honoring the survivors, and educating Jews and non-Jews across the globe who possessed little or no understanding of what came to be called the Holocaust. ${ }^{79}$ New methods of education and memorialization were needed, but the form that they would take had yet to be determined. Despite all the memorial efforts in the displaced persons camps and beyond, no single community group, practice, ceremony, or event could yet contain the enormous responsibility of memorializing the Holocaust.

\footnotetext{
${ }^{1}$ In the preface to her book, We Remember With Reverence and Love: American Jews and the Myth of Silence After the Holocaust, 1945-1962 (New York and London: New York University Press, 2009), Hasia Diner explains her long-time frustration with this misperception. In the book, she disproves the misperception — calling it a "myth"-by demonstrating a "widespread and intense American Jewish engagement with the Holocaust in precisely the years when silence had supposedly reigned," ix. Beth B. Cohen also writes about this subject in her book Case Closed: Holocaust Survivors in Postwar America (New Brunswick, New Jersey and London: Rutgers University Press, 2007). Cohen argues that in the years immediately following the war, Holocaust survivors felt that their families and American society on the whole were not interested in hearing about the Holocaust; however, the survivors themselves were anxious to talk about their experiences. The survivors, Cohen explains, talked extensively amongst themselves, built monuments, created commemorative events and memorial books, wrote plays and books, supported hometown social clubs made up of other immigrants from the same Eastern-European towns, said kaddish, and held yizkor services. In so doing, survivors began the process of remembrance and translated their need to "tell the world" into meaningful action [that] found expression through Jewish rituals of mourning" (165). Dalia Ofer also writes about the misperception of Israeli silence, stating, "I would like to take issue with [the idea that the Holocaust was ['ignored'] and maintain that the Holocaust and its meaning did capture the attention of Israelis - including the political leadership and the intellectual elite. From the end of World War II, the Holocaust was a
} 
major topic in the discourse of the Yishuv and Israel, revealing both mourning and the difficulty of comprehending its devastation" ("The Strength of Remembrance:

Commemorating the Holocaust During the First Decade of Israel," Jewish Social Studies, Volume 6, Number 2, Winter 2000 (New Series), 26).

${ }^{2}$ Leonard Dinnerstein, America and the Survivors of the Holocaust (New York: Columbia University Press, 1982), 9.

${ }^{3}$ For more information on the development of the term "Holocaust," please see my section on the subject in Chapter Four.

${ }^{4}$ Dinnerstein, America, 34.

${ }^{5}$ American historian Deborah Lipstadt explores the question of what the American public knew about the persecution of Jews in Europe leading up to and during the Holocaust in her book The American Press \& the Coming of the Holocaust 1933-1945 (New York: The Free Press, 1986). She writes, 'though the press had not previously ignored Hitler's antisemitism, most of the early reports stressed Nazi action against communists and socialists. It was only after [Kristallnacht] that the press began to focus explicit attention on the Jews' situation" (13-14). Lipstadt points out that despite the reports of violence and despite a certain amount of outrage amongst Americans hearing the reports, there was also skepticism about the accuracy of reports emerging from Europe, outright denial on the part of the Nazis, and the argument that eyewitness reports could not be verified. In later years, when reports of round-ups, deportations, and extermination emerged, the Nazis obfuscated the claims, and many Americans disbelieved the reports - not only because they seemed "improbable" but also out of a "desire to remain neutral" politically (136-137).

${ }^{6}$ Dinnerstein, America and the Survivors of the Holocaust, 38.

${ }^{7}$ In her book From Catastrophe to Power: Holocaust Survivors and the Emergence of Israel (Berkeley, Los Angeles, and London: University of California Press, 1998), Idith Zertal documents the difficulty of emigrating from the DP camps to Palestine, focusing especially on the Mossad's role in assisting refugees who wanted to enter despite British mandates against immigration (122-123).

${ }^{8}$ For more information on this topic, see Chapter Four, "The DP Camps Have Served Their Historic Purpose," of Peter Novick's The Holocaust in American Life (Boston and New York: Houghton Mifflin Company, 1999). In addition, in Michael Brenner's book After the Holocaust: Rebuilding Jewish Lives in Postwar Germany (Princeton, New Jersey: Princeton University Press, 1997), he writes about the tension that arose in the DP camps between Jews and non-Jewish Poles. He explains, "in May 1945, non-Jewish Poles in Dachau threatened the violent disruption of a Sabbath service if it were held in the main square of the camp. A soccer game between Jewish and Polish DPs ended in a stabbing when the Jewish team won. In Hohne-Belsen, Polish DPs demolished the Jewish prayer house, destroyed the Torah scrolls, and fired shots at the rabbi" (11-12). Situations like these that prompted the creation of separate camps for Jews.

${ }^{9}$ Ben Shepherd, The Long Road Home: The Aftermath of the Second World War (New York: Alfred A. Knopf, 2011), 103.

${ }^{10}$ For a detailed account of the JDC's inability to assist European Jews after the liberation, see Yehuda Bauer's American Jewry and the Holocaust: The American Joint Distribution Committee, 1939-1945 (Detroit: Wayne State University Press, 1981). 
${ }^{11}$ Shepherd, Long Road Home, 104.

${ }^{12}$ For a detailed analysis of the Joint's role during the Holocaust, see Yehuda Bauer's American Jewry and the Holocaust: The American Jewish Joint Distribution Committee, 1939-1945 (Detroit: Wayne State University Press, 1981).

13 The historian Michael Brenner writes that the DP camps were only a short phase in survivors' lives, but by this he means that survivors did not stay in the camps forever and that they lived there while regaining health and deciding how to proceed with their postwar lives, not that their experiences there were inconsequential (After the Holocaust: Rebuilding Jewish Lives in Postwar Germany, Princeton, New Jersey: Princeton University Press, 1997). Brenner explains that a minority of Jews did in fact stay in Germany after the war, and he documents in detail how difficult American Jews found the task of understanding and supporting Jews who had made the choice to stay.

14 Ruth Gay, Safe Among the Germans: Liberated Jews After World War II (New Haven and London: Yale University Press, 2002).

${ }^{15}$ Herbert Agar, The Saving Remnant: An Account of Jewish Survival (New York, New York: The Viking Press, 1960), 184.

${ }^{16}$ In her case study of the Bergen-Belsen Displaced Persons camp, New Beginnings: Holocaust Survivors in Bergen-Belsen and the British Zone in Germany, 1945-1950 (Detroit: Wayne State University Press, 2002), Hagit Lavsky describes in detail what she calls Jewish survivors" "community in transition" (216). In this new community, she argues, there was not just struggle or a feeling of entrapment but instead the development of "a unique paradigm of public Jewish life, one that had to dictate to itself new or renewed norms and values, and which struggled to crystallize and achieve a common goal" (216). Here Lavsky adds a key point to the discussion about survivors' development of successful religious, personal, and professional communities in the DP camps: the idea that they were also creating a new type of Jewish life in an environment without any precedent or pre-established norms.

${ }^{17}$ Eva Fogelman, "Coping with the Psychological Aftermath of Extreme Trauma," in Life Reborn: Jewish Displaced Persons 1945-1951, ed. Menachem Z. Rosensaft, (Conference Proceedings, Washington, D.C. January 14-17, 2000), 92, a project of the United States Holocaust Memorial Museum and the Second Generation Advisory Group in association with The American Jewish Joint Distribution Committee.

${ }^{18}$ Margarete Myers Feinstein, “Jewish Observance in Amalek's Shadow: Mourning, Marriage, and Birth Rituals among Displaced Persons in Germany," in Life Reborn: Jewish Displaced Persons 1945-1951, ed. Menachem Z. Rosensaft, Conference Proceedings, Washington, D.C., January 14-17, 2000 - a project of the United States Holocaust Memorial Museum and the Second Generation Advisory Group in association with The American Jewish Joint Distribution Committee.

${ }^{19}$ For a photograph of the monument, see Hagit Lavsky's New Beginnings: Holocaust Survivors in Bergen-Belsen and the British Zone in the Germany, 1945-1950 (Detroit: Wayne State University Press, 2002), 120-121.

${ }^{20}$ Gabriel N. Finder, "Yizkor! Commemoration of the Dead by Jewish Displaced Persons in Postwar Germany," in Between Mass Death and Individual Loss: The Place of the Dead in Twentieth-Century Germany, eds. Alon Confino, et al. (New York and Oxford: Berghahn Books, 2008), 235. 
${ }^{21}$ Finder, "Yizkor," 235.

22 When British troops liberated the Bergen-Belsen concentration camp on April 15, 1945, "they found 13,000 corpses and 58,000 prisoners - mostly Jews - still alive but in critical condition," and over the course of the next few weeks about 10,000 more died from disease, the ramifications of Nazi abuses, and starvation (David J. Hogan, ed., The Holocaust Chronicle: A History in Words and Pictures, Lincolnwood, Illinois:

Publications International, Ltd.: 2003, 579). At Dachau, many prisoners died from overeating when the Allies fed them from a truckload of bread, not knowing that the food would be a shock to digestive systems unused to large quantities of solid food (Hogan, Holocaust Chronicle, 609).

${ }^{23}$ Feinstein, M., "Jewish Observance," 261.

${ }^{24}$ In his essay "Yizkor," Gabriel N. Finder writes about burial and reburial as public forms of commemoration amongst Holocaust survivors in the DP camps. Survivors, rabbis who were survivors, and rabbis who were chaplains with the United States army worked assiduously at their collective task of burial and reburial while delivering heartfelt yizkor services at graveside - even though they could not know whether, once they left the DP camps, the gravesites would be tended or even respected (236-240).

${ }^{25}$ Feinstein, M., "Jewish Observance," 263.

${ }^{26}$ Feinstein, M., "Jewish Observance," 262-263.

${ }^{27}$ William Helmreich, Against All Odds: Holocaust Survivors and the Successful Lives They Made in America (New York, New York: Simon \& Schuster, 1992), 120 and 129.

${ }^{28}$ Feinstein, M., "Jewish Observance," 275.

${ }^{29}$ Another way in which having children enabled survivors to rebuild their lives is that it allowed them to reclaim their physical bodies as well. In Safe Among the Germans: Liberated Jews After World War II (New Haven and London: Yale University Press, 2002), historian Ruth Gay writes about male and female survivors' "not-so-secret concern" that after years of physical abuse, severe malnutrition, Nazi medical experimentation, disease, and - for women - the ensuing cessation of menses, they would no longer be fertile (67). Fortunately, she explains, "it was extraordinary...what a period of peace and adequate nourishment [in the DP camps] could do. As the marriages increased, so did the birthrate" (68). Finding that their bodies could recover from trauma to produce children gave survivors a sense of "triumph over their persecutors" and helped restore a feeling of personal freedom.

${ }^{30}$ William Helmreich, Against All Odds: Holocaust Survivors and the Successful Lives They Made in America (New York, New York: Simon \& Schuster, 1992), 121. It bears noting here that despite the positive assessment here of survivors starting families in the DP camps, there was still an enormous amount of grief undergirding even the happy occasion of the birth of children there, as exemplified in Elie Wiesel's book After the Darkness: Reflections on the Holocaust (Schocken Books: 2002). Here the New York attorney and founder of the International Network of the Children of Jewish Holocaust Survivors Menachem Z. Rosensaft states: "I was born in Bergen-Belsen. That is the essence of my being. My cradle stood only a short distance from the mass graves in which Anne Frank and tens of thousands of other European Jews lie buried anonymously. My parents survived the horrors of Auschwitz; my grandparents did not. I am alive; my brother died in a gas chamber" (43). Rosensaft's comments here evoke not only the 
horrors of the Holocaust but also the degree to which the atrocity affects children who were born as part of the renewal of Jewish life and culture documented in this chapter. ${ }^{31}$ The following discussion of women's roles in the DP camps stems from Margarete Myers Feinstein's article, "Jewish Women Survivors in the Displaced Persons Camps of Occupied Germany: Transmitters of the Past, Caretakers of the Present, and Builders of the Future," in Shofar: An Interdisciplinary Journal of Jewish Studies, Vol. 24, Number 4 (Summer 2006), 67-89.

${ }^{32}$ Feinstein, M., "Jewish Women," 76.

${ }^{33}$ Yehuda Bauer, Out of the Ashes, 210.

${ }^{34}$ Jacqueline Giere describes the survivors' political activities as rudimentary yet active and organized in her essay "We're On Our Way, but We're Not in the Wilderness" in The Holocaust and History: The Known, the Unknown, the Disputed, and the Reexamined, ed. Michael Berenbaum et al. (Bloomington and Indianapolis: Indiana University Press, 1998). In illustration of this point, she writes: "[The DPs] held local and regional elections, and they established the Central Committee of the Liberated Jews in the U.S. Zone in Germany, the Central Council, and the yearly Congress of the Liberated Jews in the American Zone, composed of locally elected delegates. Every camp had its own committee supervising offices handling matters dealing with labor, clothing, finances, cultural, and other affairs, and tried more or less successfully to organize life on a local level" (702).

${ }^{35}$ Margarete Myers-Feinstein explains that "DP performers frequently portrayed their recent suffering through song, dance and drama... [through the] staging of revues," of which music was an essential component. They performed Yiddish classics that remembered the past such as Sholem Asch's Kiddush Ha-Shem, which recalled the pogroms of the seventeenth century, and imagined the future through revues such as Tel Aviv that "imagined a future in Palestine" and skits about the Haganah. ("Re-imagining the Unimaginable: Theater, memory, and rehabilitation in the Displaced Persons Camps," in After the Holocaust: Challenging the Myth of Silence, ed. David Cesarani (London and New York: Routledge, 2012), 39-54.

${ }^{36}$ Hagit Lavsky, "The Experience of the Displaced Persons in Bergen-Belsen: Unique or Typical Case?" in We Are Here, 236. Here Lavsky explains that in Bergen-Belsen, a provisional committee for Jewish self-government in the camp with Yossel Rosensaft as chairman was set up quickly. These early postwar Jewish leaders shared the goal of Jewish reunification and cohesiveness, rallying around Zionism as a cause that all could embrace regardless of level of Jewish observance or country of origin.

${ }^{37}$ While this section focus on survivor testimony in the DP camps, it is important to note that after the war, survivors both in and out of the DP camps invested time and energy in what Laura Jockusch calls "postwar documentation initiatives" within hours of the liberation ("Chroniclers of Catastrophe: History Writing as a Jewish Response to Persecution Before and After the Holocaust" in Holocaust Historiography in Context: Emergence, Challenges, Polemics, \& Achievements, ed. David Bankier et al. (New York and Oxford: Berghahn Books, 2008), 136. In this essay, Jockusch explains that there were five major reasons for the survivors' documentation efforts: they felt that they had a moral obligation to the dead to testify; they saw practical purposes in documentation, such as bringing perpetrators to justice; they wanted to develop archival support for 
future research in the area; they saw documentation as a form of commemoration and preservation for the future; and they wanted to participate in the "distinct eastern European Jewish tradition of history writing as a response to catastrophe" (136).

${ }^{38}$ Israeli historian Dalia Ofer writes about the precedent for the Commission in her essay "The Community and the Individual: The Different Narratives of Early and Late Testimonies and Their Significance for Historians" in Holocaust Historiography in Context: Emergence, Challenges, Polemics, \& Achievements, ed. David Bankier et al. (New York and Oxford: Berghahn Books, 2008). Derived from the Oneg Shabatt archive in the Warsaw ghetto, an archive that ghetto historian Emmanuel Ringelblum collected in milk canisters in his hiding place in the ghetto, included testimonies, documents, and information about the perpetrators. Ringelblum's goals for the archive included "assembling Jewish documents about deportations and killings and ensuring that as many details and names as possible were recorded, along with precise indications of places and dates, because these were topics that the Germans and their collaborators would certainly want to obscure" (520). As Ofer explains, after the war testimony collection proceeded according to Ringelblum's parameters (521).

39 Atina Grossmann, "Entangled Histories and Lost Memories: Jewish Survivors in Occupied Germany, 1945-49" in We Are Here: New Approaches to Jewish Displaced Persons in Postwar Germany, ed. Avinoam J. Patt et al. (Detroit: Wayne State University Press, 2010), 19.

${ }^{40}$ Atina Grossmann, "Entangled Histories," 24.

${ }^{41}$ The work of the Historical Commission did constitute the first attempts at collecting testimony in the DP camps, but the Commission's efforts were by no means the first Holocaust-era Jewish testimonies recorded. In Israeli historian Dina Porat's essay, "First Testimonies on the Holocaust: The Problematic Nature of Conveying and Absorbing them, and the Reaction in the Yishuv" in Holocaust Historiography in Context:

Emergence, Challenges, Polemics, \& Achievements, ed. David Bankier et al. (New York and Oxford: Berghahn Books, 2008), she writes about Jewish European refugees in Palestine giving testimony about the terrible conditions that they had faced in their homelands: ghettos, transports, and extermination. As Porat explains, despite the refugees' horrifying reports, "It seems that one account of the Holocaust, even if it was absolutely the first, and even if it was the testimony of an entire group of people, was not enough; it was necessary for many witnesses to come forward over a long period before the whole picture could be absorbed" (449). Only in the wake of repeated, numerous testimonies did fellow Jews begin to believe the refugees' testimonies.

${ }^{42}$ Laura Jockusch, “A Folk Momument to Our Destruction and Heroism: Jewish Historical Commissions in the Displaced Persons Camps of Germany, Austria, and Italy," in We Are Here: New Approaches to Jewish Displaced Persons in Postwar Germany, ed. Avinoam J. Patt et al. (Detroit: Wayne State University Press, 2010), 31.

${ }^{43}$ The information cited here, as well as other observations and information about the Historical Commissions, can be found in Laura Jockusch's detailed and thorough essay on the subject, "A Folk Momument to Our Destruction and Heroism: Jewish Historical Commissions in the Displaced Persons Camps of Germany, Austria, and Italy," in $W e$ Are Here: New Approaches to Jewish Displaced Persons in Postwar Germany, ed. Avinoam J. Patt et al. (Detroit: Wayne State University Press, 2010). 
${ }^{44}$ Important though the Historical Commissions were, they are not the only source of survivor testimony from the DP camps. Psychologist David Boder interviewed roughly 130 survivors there in nine languages from July 29 to October 4, 1946 and recorded all of them. He also recorded song sessions and religious services in the DP camps and spent the following ten years of his career analyzing and publicizing the testimonies. The Holocaust scholar Alan Rosen's study of Boder and his work, The Wonder of Their Voices: The 1946 Holocaust Interviews of David Boder, (Oxford University Press: 2010), viii, includes excerpts from the interviews, lists of interviewees along with their names, ages, occupations, and language spoken, photographs of Boder and his equipment, a detailed analysis of Boder's approach to testimony, and an examination of the very nature of oral testimony.

45 Jockusch, "A Folk Monument," 37.

${ }^{46}$ Boaz Cohen, "The Children's Voice: Postwar Collection of Testimonies from Child Survivors of the Holocaust," Holocaust and Genocide Studies, Vol. 21, No. 1 (Spring 2007): 90.

${ }^{47}$ Beate Muller, "Trauma, Historiography and Polyphony: Adult Voices in the CJHC's Early Postwar Child Holocaust Testimonies," History \& Memory, Vol. 24, No. 2 (Fall/Winter 2012): 161. 48 Jockusch, "A Folk Monument," 35.

${ }^{49}$ Laura Jockusch's book, Collect and Record!: Jewish Holocaust Documentation in Early Postwar Europe, provides a detailed account of the Commission's work (New York, New York: Oxford University Press, 2012). Jockusch locates the work of the Historical Commission in what she calls "a distinct 'historiography of trauma,' a genre of historical documentation which had developed under the impact of anti-Jewish violence in the early twentieth century...best termed khurbn-forshung, Yiddish for 'destruction research" that has as its primary motivation "legal, material, and moral redress" (19). She traces this genre back to the 1903 Kishniev pogrom (19) and to the ensuing attempts to document it, arguing that the documentation of the pogrom "served as the intellectual and methodological underpinnings of the postwar documentation projects in liberated Europe" after the Holocaust (36). In related work, Margarete Myers Feinstein explains that newspapers published in the DP camps "helped to spread the work of the...Commission... seeking to collect survivors' testimonies both to preserve the history of the Holocaust and to find useful witnesses against war criminals," Holocaust Survivors in Postwar Germany: 1945-1957 (New York, New York: Cambridge University Press, 2010), 224.

${ }^{50}$ David Cesarani reports that "between 1944 and 1949, the commission distributed numerous questionnaires and conducted about 5,000 interviews" and explains that "given that the number of survivors of the camps and ghettos in Poland was 40,000-50,000, this demonstrates a significant willingness to record and talk, but certainly not 'silence."' ("Challenging the 'Myth of Silence': Postwar responses to the destruction of European Jewry" in After the Holocaust: Challenging the Myth of Silence, ed. David Cesarani et al. (London and New York: Routledge, 2012), 16.

${ }^{51}$ For more detailed information on the Historical Commission's questionnaires, see page 51 of Laura Jockusch's essay, "A Folk Monument," and the section entitled "Collection Methods” in Ada Schein's essay “"Everyone Can Hold a Pen': The Documentation 
Project in the DP Camps in Germany," in Holocaust Historiography in Context: Emergence, Challenges, Polemics, \& Achievements, ed. David Bankier et al. (New York and Oxford: Berghahn Books, 2008). Schein points out that in addition to distributing and then gathering the completed questionnaires and collecting testimony, the Commission also collected official Nazi documents; photographs and "other museumquality artifacts;" and even the lyrics and tunes of songs (114). ${ }^{52}$ According to Yehuda Bauer in his book Out of the Ashes: The Impact of American Jews on Post-Holocaust European Jewry (Pergamon Press, 1989), 211-212, Fun Letztn Churbn was "a historical journal of a very high standard," published at a time during which "people told their stories, wrote pieces discussing their views on why [the Holocaust] had happened, analyzing their own past in a remarkably dispassionate and objective way."

${ }^{53}$ Yehuda Bauer, Out of the Ashes: The Impact of American Jews on Post-Holocaust European Jewry (Pergamon Press, 1989), 167. As Jan Schwarz explains in "A Library of Hope and Destruction: The Yiddish Book Series 'Dos poylishe yidntum' (Polish Jewry) 1946-1966," in Polin: Studies in Polish Jewry, Volume Twenty: Making Holocaust Memory, ed. Gabriel N. Finder et al. (Oxford and Portland, Oregon: The Littman Library of Jewish Civiliation, 2008). Poland was also the location of a large Yiddish publishing house that thrived from 1946 until 1966 when it published its $175^{\text {th }}$ and final volume of an extensive Jewish memorial book series, Dos Poylishe yidntum (174). Schwarz describes this feat in superlative terms, writing that "Dos poylishe yidntum became one of the most remarkable memorials to the destroyed Polish Jewish community" (175).

54 Jockusch, "A Folk Monument," 44-45.

${ }^{55}$ William B. Helmreich, "Against All Odds: Survivors of the Holocaust and the American Experience," in The Holocaust and History: The Known, the Unknown, the Disputed, and the Reexamined, ed. Michael Berenbaum et al. (Bloomington and Indianapolis: Indiana University Press, 1998), 751.

${ }^{56}$ Helmreich, "Against All Odds," 751.

${ }^{57}$ Ben Eididin, Jewish Community Life in America (New York, New York: Hebrew Publishing Company, 1947), 17.

${ }^{58}$ Dorothy Rabinowitz, New Lives: Survivors of the Holocaust Living in America (New York, New York: Alfred A. Knopf, 1976), 105.

${ }^{59}$ For a detailed account of Jewish migration to Miami and Los Angeles, see Deborah Dash Moore's To the Golden Cities: Pursuing the American Jewish Dream in Miami and Los Angeles (New York, New York: The Free Press, 1994) and her chapter, "Jewish Migration in Postwar America: The Case of Miami and Los Angeles," in The American Jewish Experience, ed. Jonathan Sarna (New York and London: Holmes \& Meier, 1986). ${ }^{60}$ Max Gottschalk and Abraham G. Duker, Jews in the Post-War World, (New York, New York: The Dryden Press, 1945), 86.

${ }^{61}$ Ruth Gay, Unfinished People: Eastern European Jews Encounter America (New York and London: W. W. Norton \& Company, 1996), 298-299.

62 Jonathan Sarna, American Judaism: A History (New Haven \& London: Yale University Press, 2004), 274.

${ }^{63}$ Sarna, American Judaism, 275. 
${ }^{64}$ In his essay, "Who Shall Bear Guilt for the Holocaust? The Human Dilemma," in The American Jewish Experience, ed. Jonathan D. Sarna (New York \& London: Holmes \& Meier, 1986), Henry L. Feingold argues that "American Jewish leadership [at the time of the Holocaust] might be accused of ignorance, ineffectiveness, or just sheer lack of stature...but the charge of betrayal is unwarranted and unfair." As Feingold explains, leaders in Washington and many Jews simply did not believe the reports of mass murder coming from Europe. He writes that in "a poll of Americans in January 1943, when an estimated one million Jews already had been killed, indicated that less than half the population believed that mass murder was occurring. Most thought it was just a rumor." It was not until May of 1945, "when Americans already had seen pictures of the camps [that] the median estimate rose to one million, and 85 percent were now able to acknowledge that systematic mass murder had taken place. The inability to understand the immensity of the crime extended to the Jewish observers around the periphery of occupied Europe. They underestimated the number who had lost their lives [by that point in time] by a million and a half. The figure of six million was not fully established until the early months of 1946" (288-289).

${ }^{65}$ The information presented here and in the following paragraphs can be found in Edward S. Shapiro's A Time For Healing: American Jewry Since World War II (Baltimore and London: Johns Hopkins University Press, 1992). Arthur A. Goren's chapter in A Time For Healing, "A Golden Decade for American Jews: 1945-1955," also discusses the American Jewish community's role in supporting refugees and immigrants financially, with contributions rising from " $\$ 57.3$ million in 1945 to $\$ 131.7$ million in 1946 and to $\$ 205$ million in 1948, when 80 percent of the monies raised went for settling immigrants in Israel" (Jonathan D. Sarna ed. The American Jewish Experience. New York and London: Holmes \& Meier, 1986, 296).

${ }^{66}$ Samuel G. Freedman, Jew vs. Jew: The Struggle for the Soul of American Jewry (New York, New York: Simon \& Schuster, 2000), 280.

${ }^{67}$ Jonathan D. Sarna, American Judaism, 281.

${ }^{68}$ Riv-Ellen Prell, Fighting to Become Americans: Jews, Gender, and the Anxiety of Assimilation (Boston: Beacon Press, 1999), 57, and Jenna Weissman-Joselit, The Wonders of American: Reinventing Jewish Culture, 1880-1950 (New York: Henry Holt and Company: 1994), 159.

69 Albert I. Gordon, Jews in Suburbia (Boston: Beacon Hill Press, 1959), 243.

${ }^{70}$ Deborah Dash Moore, "Jewish Migration in Postwar America: The Case of Miami and Los Angeles," in The American Jewish Experience, ed. Jonathan D. Sarna (New York and London: Holmes \& Meier, 1986), 317-318.

${ }^{71}$ Moore, "Jewish Migration," 321-323.

72 Jack Kugelmass and Jonathan Boyarin's From a Ruined Garden: The Memorial Books of Polish Jewry (Indianapolis: Indiana University Press, 1998) provides not only detailed background information about Eastern-European Jewish memorial books but also gives dozens of examples of the text of the books. Information for the section of this chapter that covers landsmanschaftn and yizker-bikher can be found therein.

${ }^{73}$ Moore, "Jewish Migration," 321-323.

${ }^{74}$ Jack Kugelmass and Jonathan Boyarin, ed., From a Ruined Garden: The Memorial Books of Polish Jewry (Indianapolis: Indiana University Press, 1998), 10. 
${ }^{75}$ James E. Young, The Texture of Memory: Holocaust Memorials and Meaning (New Haven and London: Yale University Press, 1993), 7.

${ }^{76}$ In her book Trespassing Through Shadows: Memory, Photography \& the Holocaust (Minneapolis \& London: University of Minnesota Press, 1998), Andrea Liss argues that while yizker bikher existed after World War I, their proliferation after World War II is due to the effect of "the aftermath of the Nazi mass murders and the disappearance of entire communities" (33). Liss posits that these factors "redefined the purpose of the yisker biher," magnifying their moral responsibility to "chronicle the events of destruction and to simultaneously attest to the memory and vibrancy of what was" (3334). There is again here the pattern of rebuilding through historical documentation and memorialization.

${ }^{77}$ Zeev W. Mankowitz, Life Between Memory and Hope: The Survivors of the Holocaust in Occupied Germany (Cambridge, England: Cambridge University Press, 2002).

${ }^{78}$ Here the survivors' efforts to memorialize the dead is just as much a part of what Yehuda Bauer calls "the Jewish emergence from powerlessness" as was many survivors' commitment to Zionism and the State of Israel. Just as they played a critical role in the Jews' transition from a position of utter powerlessness and statelessness to success of Zionism and the founding of the State of Israel, so did they play a critical role in the transformation that took place so quickly in the DP camps: from extermination and incarceration to revival and memorialization. (The Jewish Emergence from Powerlessness. Toronto and Buffalo: Toronto University Press, 1979, 41- 78.)

${ }^{79}$ In her article about Israeli Holocaust commemoration and practice, Dalia Ofer writes about the problem that arose when the average Israeli student learned about the Holocaust primarily from attending commemoration events. She writes that "thus, the knowledge that the young student received was neither systematic nor coherent, and was completely divorced from any historical context. It was loaded with phrases suitable for commemoration ceremonies and aimed at engaging the participants emotionally," not intellectually ("We Israelis Remember, But How? The Memory of the Holocaust and the Israeli Experience," in Israel Studies, Volume 18, No. 2, Summer 2013, 80). In response to these concerns, Holocaust education eventually — not until 1985 - became mandated in Israeli high schools. I would argue that Holocaust museums attempt to fill both an intellectual and an emotional gap for their audiences, wherever they are located. In the United States, so few states mandate Holocaust education that the problem of a purely emotional and not historically-grounded understanding of the Holocaust also exists. Holocaust museums help to compensate for the lack of Holocaust education in schools across the country through tours of the museums, online programming, distance learning, and teaching training. 


\section{CHAPTER TWO: HOLOCAUST REMEMBRANCE IN ISRAEL AND GERMANY}

As the previous chapter demonstrates, post-Holocaust memorial practices were widely in place in Jewish communities around the world after the war, but these practices were centered in the Jewish community and thus were not readily accessible to the wider public. This chapter distinguishes between private and synagogue- or Jewish community-based Holocaust memorial practices and Holocaust memorials, monuments, and museums, then focuses on the development of two Holocaust museums outside of the United States: the Israeli Holocaust museum, Yad Vashem, and the Jewish Museum Berlin in Berlin, Germany, with United States Holocaust museums to be covered in the following chapter. Although these two museums are disparate in time and location - the inception of Yad Vashem in 1953 predates the Jewish Museum Berlin's opening in 2008 by fifty-five years - each museum is a reflection of the primary concerns of its home country and by its relationship to other countries too. Kendall R. Phillips and G. Mitchell Reyes, scholars of the visual and performing arts and of media studies, respectively, write that museums fit into a "global memoryscape," which they define as a "complex landscape upon which memories and memory practices move, come into contact, are contested by, and contest other forms of remembrance."1 These memoryscapes influence the Holocaust museums built into them: in Israel, a country flooded with Holocaust survivors after the war, there was an enormous desire to secure a safe haven for Jews there, memorialize the Holocaust, and confront threats to Jewish life and liberty. In Germany, a war-torn country mired in shame, almost absent of Jews, and unsure of how to proceed, Holocaust memorialization was neither a high priority nor a plausible reality. 
These memoryscapes have had a profound effect on each museum. Despite these differences between the memoryscapes of Israel and Germany and between the two museums, however, there are some commonalities between the museums that demonstrate how they are not only a part of the memoryscapes of their home countries but also a part of a more global memoryscape: each museum plays a distinctive role in the instantiation of Holocaust history and remembrance in its home country, and each museum has a distinctive location, architecture, and function on the national level. As a result, each museum also plays an active role in the cultural and memorial life of the city in which it is located, bestowing upon the institution of the museum almost sole responsibility for driving Holocaust remembrance in that country. In this chapter, the Jewish Museum Berlin is contrasted with Yad Vashem and examined as an example of Germany's quest to confront its past while cultivating Jewish life in a city that had been literally emptied of Jews during the Holocaust.

\section{Memorials, Monuments, and Museums}

After the Holocaust, a network of Holocaust memorials, monuments, and eventually museums developed in Europe and in the United States. Judaic Studies scholar James Young articulates the distinction between monuments and memorials - and thus between monuments, memorials, and museums — in his book The Texture of Memory. Young explains that there are many different types of memorials - memorial books, festivals, days, and sculptures — and that monuments are a subset or type of memorial, "the material objects, sculptures, and installation used to [honor the memory of] a person or thing." 2 Young concludes that while a monument is always a type of memorial, a 
memorial need not take the form of a monument. In his later book, At Memory's Edge, Young argues that

as intersection between public art and political memory, the monument has necessarily reflected the aesthetic and political revolutions, as well as the wider crises of representation, following all of the century's major upheavals - including both World Wars I and II, the Vietnam War, the rise and fall of communist regimes in the former Soviet Union and its Eastern European satellites. ${ }^{3}$

Monuments have come to mark moments of tension, tension between the past and the present, between a city or country's traumatic past and its attempt to create healing, and between history and aesthetics. They are an important way for whole communities and cultures to remember the past.

In Europe, some of the first Holocaust monuments were built on the grounds of the concentration camps themselves, on the actual "sites of destruction": in July of 1944 at Majdanek, in 1945 at Buchenwald, and in 1947 at Auschwitz-Birkenau. ${ }^{4}$ One of the most famous Holocaust monuments can be found in Warsaw, Poland, where the unveiling of sculptor Nathan Rapoport's Warsaw Ghetto Monument took place in Warsaw on April $19,1948 .^{5}$ Other concentration camp monuments followed over the yearsBuchenwald's "Memorial to a Memorial" in 1995 and the Belzec Memorial in 2004though all of the concentration camps are considered memorial sites, meaning that they are geographic locations meant to be preserved because an important historical event, in this case an atrocity, took place at the actual location. Holocaust memorials can be found in cities across Europe, in places such as Budapest, Hungary; Kracow, Poland; Vienna, 
Austria; Antwerp, Belgium; and Kaunas, Lithuania, to name but a few, and in cities throughout the United States. Monuments are different from museums even though both are considered memorials. While they may serve a given community as a locus for memorial services or as a touchstone of remembrance for a given city, they cannot offer the resources of a museum: educational programming, teacher training, and the display of artifacts, photographs, and documents. Monuments also usually take the form of sculptures or structures that are outdoors, so they cannot offer in-depth educational programming, serve as a repository for collections, contain a library and its resources, facilitate regular survivor testimony, or house extensive permanent exhibitions—-but museums can and do. Museums therefore have the capacity to perform the work of remembrance, as the next two sections of this chapter demonstrate.

\section{Yad Vashem}

While Yad Vashem Holocaust Martyrs' and Heroes' Remembrance Authority was not the first form of Holocaust commemoration in Israel, ${ }^{6}$ it was the first Holocaust museum there and in the world. The Israeli Knesset established Yad Vashem in Jerusalem in 1953, but plans for it, for a memorial museum that "should be acceptable to all the diverse parties in Israel and to the entire Jewish people" began as early as $1945 .^{7}$ Established in the newly founded state of Israel, the museum was meant from its inception to be a national, secular institution built within a Zionist framework ${ }^{8}$ that would include Jewish religious elements but not include a synagogue or align itself with one particular branch of Judaism. The Knesset "authorized [the museum] to document the destruction of the Jews and also their resistance, and it was charged additionally with the 
responsibility of commemorating the martyrs and heroes of that destruction." ${ }^{9}$ It was also intended to enshrine in Israel the task of commemorating the Holocaust ${ }^{10}$ in a memorial that would be immense and unforgettable and to bear the responsibility of "shaping a hegemonic narrative of the Holocaust." "11 This narrative, one that would indelibly link the Holocaust and virtually all aspects of Israeli life — political, cultural, historical— would expand over the years to include non-museological methodologies. Holocaust scholar Saul Friedlander writes, "indeed, the lasting impact of this past on the hundreds of thousands of survivors who reached the country — often on their children as well— the establishment of national rituals of commemoration, the development of specific school curricula, a fast-growing historiography, the ongoing use of media dramatizations, as well as artistic and literary reelaborations of the events, have created a vast domain of public reference to [the Holocaust]." ${ }^{\prime 12}$ In Israel, Yad Vashem is the architectural and museological interpretation of the Holocaust that emerged as part of a narrative that has tributaries throughout Israeli society. ${ }^{13}$

Yad Vashem is located on a hill in Jerusalem known as Har Hazikaron, or "the Mountain of Memory," a hill on whose other side one finds the Mount Herzl military cemetery, which is named for the great Zionist Theodor Herzl. ${ }^{14}$ Herzl is buried along with other notable Zionists, prominent Israeli officials such as Golda Meir and Yitzhak Rabin, and Israeli soldiers who died fighting for Israel. Surrounded by native trees, the cemetery is a beautiful, natural, contemplative memorial space. Along with Yad Vashem, it is arguably one of the two most important memorial sites in Israel. The sociologist Shaul Kelner writes that "the hill's architecture powerfully inscribes in Jerusalem's landscape a 
narrative whose ashes-to-redemption, exile-to-home, death-to-resurrection motifs, draw from the deepest wells of human myth."15 The presence of the cemetery and of Yad Vashem on the same mountain inscribes into the topography of Jerusalem a practice of memorialization, and it literally prioritizes memorialization over all else. Along with the cemetery, Yad Vashem has become known as one of the "iconic," morally significant places to visit for visitors taking tours of Israel. As Kelner argues, the "ritual" of visiting the museum "reestablish[es] Israel's geography as an object of Jewish devotion, echoing an ancient pilgrimage tradition but realizing it through contemporary tourist practices."16 The museological intention behind these pilgrimages to Yad Vashem is that the museum will tell the horrible story of the Holocaust while demonstrating the strength of the Jewish people and the necessity of Israel as a site of safety for Jews around the world. ${ }^{17}$

When Yad Vashem first opened, however, it was not the sophisticated, architecturally distinctive museum that it is today. In his book published in 1993, The Seventh Million: The Israelis and the Holocaust, ${ }^{18}$ Israeli historian Tom Segev described the original Yad Vashem as "unremarkable.", He characterized the museum as underfunded, its exhibitions as old and "grimy," its photographs as "revolting," and its exhibit labels as "long" and "didactic" in tone. ${ }^{20}$ Israeli genocide scholar and historian Omer Bartov wrote in 1997 that "though a national institution, [Yad Vashem] is a poor man's exhibit. Its power is derived from both its location and the event it commemorates." ${ }^{21}$ Bartov made an important distinction here, that at Yad Vashem, location and subject matter imbued the museum with "power" even though its exhibitions at the time left much to be desired. His suggestion, that Yad Vashem was powerful despite its exhibitions, is 
prescient, for the next iteration of Yad Vashem proved to be powerful because of its location, its subject matter, its architecture, and its exhibitions - as described below. Until then, and despite the critiques cited here, Yad Vashem was still considered to be of central importance in Israeli society not just as a symbol of the Holocaust but also for the role it plays in "Israeli civil religion," where the museum "assume[d] a sanctity not only because it symbolizes six million Jews who died but because it symbolize[d] the Jewish people and culture of the Diaspora whose suffering and death legitimize[d] the Jewish right to Israel." ${ }^{22}$ The museum's being sited not just in Israel but on Har HaZikaron connected it to those who fought for Israel's existence, guided its early years of statehood, died in the diaspora during the Holocaust, and perished fighting for its right to exist.

In light of these powerful connections and the museum's importance in the postHolocaust memorial culture of Israel, over time Yad Vashem continued to expand beyond its original form. The various buildings that made up the complex grew to include "the library, archive, and administrative building (1957), the Hall of Names and Synagogue building (1965), and the history museum (1973)."23 They were "modern, functionalist structures clad in Jerusalem stone" whose "sober design was in keeping with the era's modernist architectural principles" and whose architectural "restraint reflected the Holocaust's marginalized place in public discourse in Israel, Europe, and the United States." ${ }^{24}$ The only exception to this practice of architectural restraint came from Israeli architect Arieh Elhanani, whose design for the 1961 Ohel Yizkor, or Hall of Remembrance at Yad Vashem, "combined modern and ancient forms to create a 
powerful, albeit abstract, memorial edifice. ${ }^{25}$ None of these original structures at Yad Vashem referenced the Holocaust in an overt or direct way, in an effort to memorialize without exactly replicating Holocaust "architecture."

Years later, when tensions were swirling around the creation of United States Holocaust museums such as the United States Holocaust Memorial Museum in Washington, D.C. and the Museum of Tolerance in Los Angeles in the 1980s and early 1990s, officials at Yad Vashem paid careful attention. They did not want Yad Vashem to be overshadowed, so in 1993, the same year that the Holocaust Memorial Museum and the Museum of Tolerance opened, museum officials began to plan for a new Yad Vashem. They hired Israeli-born, Canadian-American architect Moshe Safdie to design a new version of the museum, which opened in 2005 and is now four times its original size. ${ }^{26}$ The new museum has been widely acclaimed. Safdie preserved some of the original buildings but created anew the historical museum, the visitors' center, the synagogue, the sunken courtyard, and the café. In 1990, the Polish government gave to Yad Vashem an "authentic" boxcar "of the type used for transporting Jews," which Safdie had placed onto rail tracks that "stretch out from the hilltop of Yad Vashem" and stop abruptly, with the tracks and the boxcar hovering "on the edge of the world...a memorial to destruction." ${ }^{27}$ It is an utterly disconcerting sight to see a railroad car jutting out over a hillside, perched on the edge of destruction. 


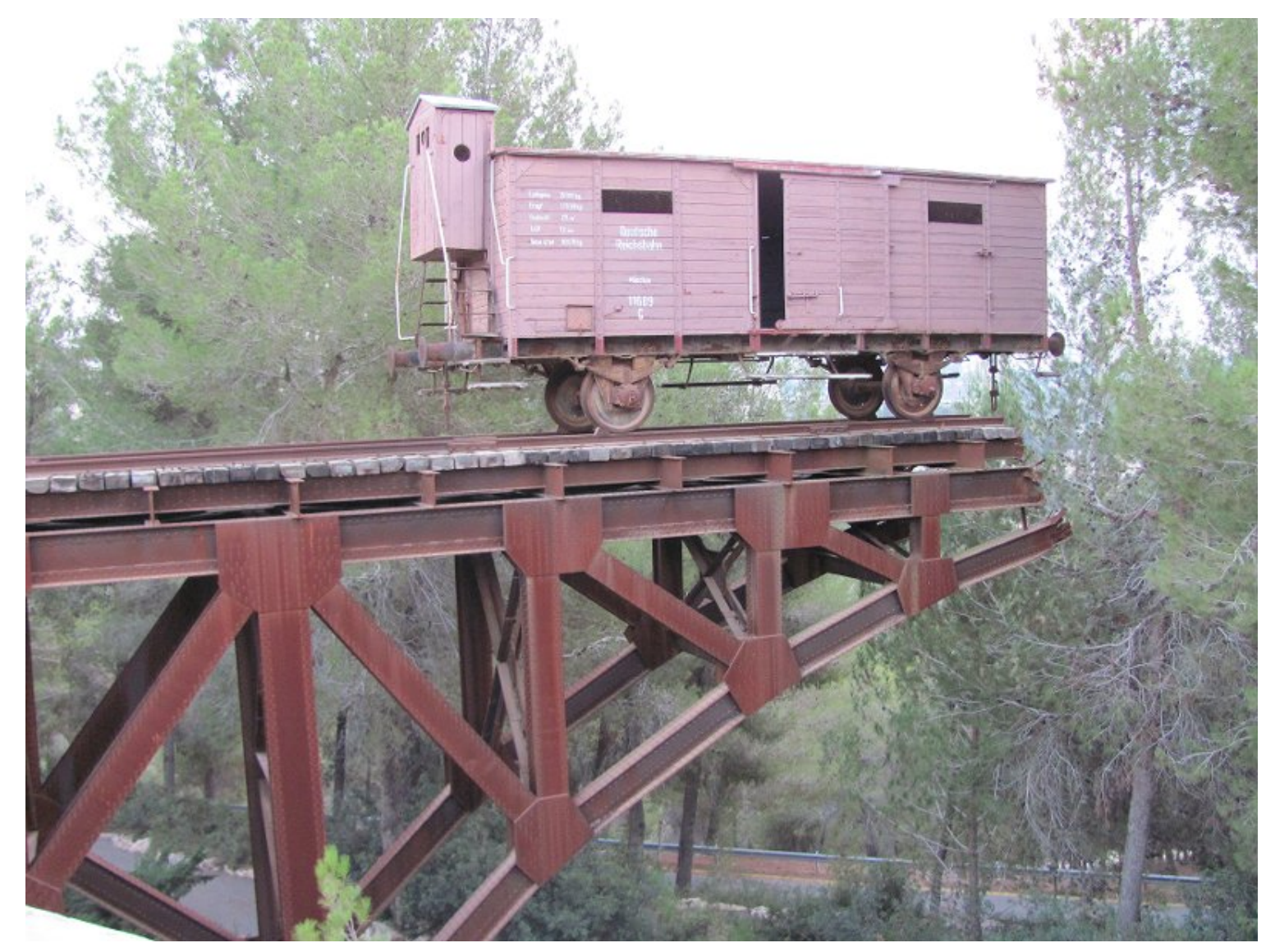

Yad Vashem, Jerusalem. Holocaust boxcar http:/www.garystravels.com/wp-content/uploads/2012/02/ph2860183450080183838.jpg. Accessed September 16, 2013.

With the positioning of the boxcar in this way, Safdie uses what is the museum's largest artifact in an abstract way, but historical information is presented more concretely throughout the museum through the use of smaller artifacts, written materials, and over one hundred video screens showing survivor testimonies and short films. According to the cultural historian Simon Goldhill, the new Yad Vashem "aims to hold a record- the name that shall never be effaced — of each and every victim... and it is deeply moving. The building itself is part of the story the museum tells...it is one of the most powerful examples of how architecture can enforce an ideology." 28 The architecture of the new museum alludes to the Holocaust in metaphorical ways: the structure of the building prevents visitors from walking in a direct path through the museum, creating a sense of 
disorientation; the triangular interior space constricts as visitors proceed further and further into the museum, creating a feeling of restricted freedom; and at the very end of the museum, visitors are released onto a cantilevered space that thrusts them out over the glorious landscape of Israel, creating the sensation of freedom and relief. ${ }^{29}$ With this new architecture, as with the old, Yad Vashem continues to define and influence the memorial narrative of Israel, though in a less "monolithic way" than when it first opened. ${ }^{30}$ In the words of New York Times museum critic Edward Rothstein,

the museum offers no lessons and promises no relevance. The stories, facts and analyses accumulate until you begin to comprehend something beyond comprehension. The museum's implied conclusion is sensed rather than taught: after the harrowing history, you are brought back, finally, to the present, in somber gratitude. ${ }^{31}$

Here Rothstein implies that the visitor's experience of the new Yad Vashem stems not from one architectural motif, one artifact, or one film; instead, the museum's many facets create a multi-layered aggregate out of which one emerges sobered and deeply present.

\section{The Jewish Museum Berlin}

The Jewish Museum Berlin opened on September 9, 2001, after decades of first attempts, previous iterations, a tense competition for its design, and multiple phases of planning. Unlike Yad Vashem, which is located in a country that served as a haven for Jewish refugees and Holocaust survivors, the Jewish Museum Berlin is located in the very city that was the capital of the Third Reich and the locus of planning for the Final Solution-a deeply perplexing and problematic truth of which the museum's planners were distinctly mindful. Berlin's role as the capital of the Third Reich has left the city with an admixture 
of guilt and shame about and at times rejection of its Nazi past. Museum planners had to address these issues by acknowledging the city's history in a way that was accurate but still did not alienate German visitors: a tall order indeed. The Jewish Museum Berlin is thus examined here as a case in contrast to Yad Vashem.

The scholar of comparative literature Svetlana Boym writes about the tension between memory and history in Berlin in her book The Future of Nostalgia. She writes:

Memories, of course, are contested. It is dangerous to sentimentalize destruction or to mend political evil with emotional attachments.

Nowhere is this more clear than in the center of Berlin, where every site is a battleground of clashing nostalgias and future aspirations. ${ }^{32}$

Here Boym acknowledges that in a city rife with memorial landmarks and awash in the tragic remnants of its Nazi past, there is no escaping the constant intermingling of past and future. As Boym explains, the past must be treated carefully and accurately, not simply with sentimentality and emotionality. In Berlin, some of the city's very buildings comprise what journalist Michael Z. Wise calls "Nazism’s architectural remnants," buildings that the Third Reich had commissioned "to deploy monumental architecture as a propaganda tool and use huge public construction projects as a means of job creation and economic revival in the 1930s." 33 In other words, the Third Reich oversaw the creation of parts of Berlin as a way to inspire Germans aesthetically, increase public confidence, and rebuild the economy after the devastation of World War I. In so doing, the Third Reich inserted itself into Berlin literally and figuratively, enlisting the city and its citizens as partners in its own reinvigoration while creating trust in and ominous 
support for the reich. The past is instantiated in the walls of the city. If Yad Vashem is built upon what is hallowed ground for the Jewish people, then the Jewish Museum Berlin is built upon the opposite: land that saw buildings built as vehicles of propaganda, the desecration of synagogues and Jewish storefronts during Kristallnacht, the deportation of Jews to the concentration camps, and the destruction of Berlin's longstanding Jewish community. The distinction between past and future in Germany is so sharp that there is even a word in German for the postwar generation, "Nachgeborenen"- those who were born after the war and thus bear no direct responsibility for the crimes committed. ${ }^{34}$ The Jewish Museum Berlin is constructed upon the soil of a country that emerged from World War II "dismantled" and "fundamentally altered," ${ }^{35}$ and building a memorial museum to the Holocaust on such ground requires addressing the notion of German responsibility for and complicity in the Holocaust, situating the museum as an arbiter of moral responsibility in German society. ${ }^{36}$ The museum faces what James Young calls Germany's "paralyzing Holocaust memorial problem," its "double-edged conundrum" that wonders how "a nation of former perpetrators [would] mourn its victims" and —at the same time — how "a divided nation [would] reunite itself on the bedrock of the memory of its crimes." ${ }^{37}$ The sociologist Irit Dekel uses the phrase the "dimension of annihilation" to describe the European and German focus on perpetration that the museum must address. ${ }^{38}$ No other country in the world, when building a Holocaust museum, would confront these exact problems.

Located amongst the charming streets of Berlin's former Jewish quarter, the new museum stands out conspicuously against its surroundings and in comparison to the 
building to which it is joined, the baroque-style "Old Building" or "Collegienhaus." The Old Building, built in 1735, was an administrative building until the early 1960s, during which time it was renovated to accommodate the Berlin Museum, a museum devoted to the history of Berlin. ${ }^{39}$ While the Berlin Museum did include space for information about the history of Jews in Berlin, it did not do justice to the richness of the history of Jewish life and culture in the city, and it did not acknowledge the Holocaust. After much deliberation and an intense debate over where and how to situate a Jewish museum in relation to the Berlin Museum, ${ }^{40}$ museum officials opted to create a Jewish Museum with its own distinct space that could illuminate and grapple with the complexity of GermanJewish history. As the German studies scholar Jennifer Hansen-Glucklich wrote in her 2011 dissertation, "the Berlin Senate knew that it wanted a Jewish history museum, not a Holocaust museum, but it recognized that the Holocaust had to be present in the museum, and that exile, displacement and death would need to be part of the story." ${ }^{, 41}$ The intention was to integrate German-Jewish history into the history of Berlin while still maintaining a distinction between the two. ${ }^{42}$ A publication of the museum, Discovering the Jewish Museum Berlin, explains that financial support for the museum comes from all corners of German society: the federal government, the state, varying political parties, and diverse public groups and individuals. ${ }^{43}$ This support, stemming as it does from all corners of German society, is meant to demonstrate not only a commitment to the museum as it exists today but also a determination to preserve even the ugliest aspects of German history. ${ }^{44}$ The museum was not to be a "reintroduction of Jewish memory into Berlin's civic landscape but an excavation of memory already there, though long suppressed. ${ }^{, 45}$ In recognition of the difficulty and enormity of this task, museum 
officials announced that there would be an international competition for the best design for the new museum; Daniel Libeskind, the Lodz, Poland-born son of Holocaust survivors, won first place for a design that has become world-renown and that has placed the Jewish Museum Berlin in a superlative category.

When seen from above, the Jewish Museum Berlin resembles a shiny zigzag or lightening bolt, like a silver scar on the lanscape; it is hardly the "tasteful and discreet" type of memorial that German citizens had wanted and created in the past. ${ }^{46}$ From the street, its zinc façade alone would differentiate it noticeably from the surrounding buildings, but the building's exterior is surprisingly slashed with what appear to be dark lines and dark geometric shapes. Inside, the zigzag shape and the slashing lines of the exterior create a disquieting aesthetic experience and a series of spatial voids that intentionally fragment the interior. Unlike most museums and other public buildings, the intent is not to make navigation of the space intuitive for the visitor or to make its exterior innately pleasing. Instead Libeskind intends to "integrate physically and spatially the meaning of the Holocaust into the consciousness and memory of the city of Berlin," 47 to use his "deconstructivist inclination to evoke absence and loss",48 as a way to fuse German history and Jewish history. In an interview in 2000, the museum's former Deputy Director and Chief Executive Officer Tom Freudenheim explains that the museum "itself has the Holocaust built into it. You never escape from it and maybe that's the most important symbolic value, in the sense that it isn't dependent upon exhibitions. One way or another, if you are in Berlin, you can't escape the Holocaust. All of Berlin is a memorial site." ${ }^{49}$ Freudenheim's analysis here pinpoints the distinct 
challenge of the museum, that it is being built in a city so complicit in the Holocaust that its every nook and cranny has memorial value and historical significance. ${ }^{50}$

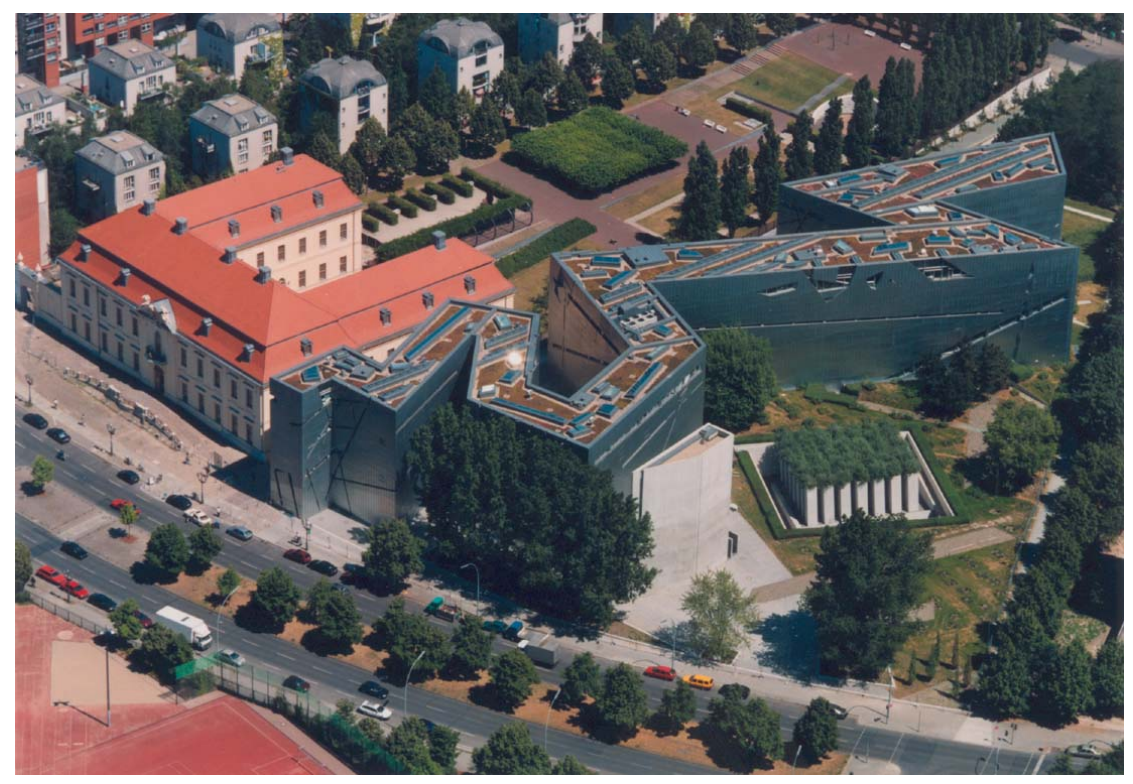

Jewish Museum Berlin. http://1.bp.blogspot.com/--4-xv6W87b4/ Toa2ES8jT_I/ AAAAAAAAOLs/ YGUN6V_vM4Y/s1600/Jewish_Museum_Berlin_2_2.jpg. Accessed September 16, 2013.

The museum's now-iconic exterior architecture and its now-legendary interior spacesrife with voids and dead-ends ${ }^{51}$ — does not comprise the entirety of the museum, however. Through the use of artifacts, film clips, an "Emancipation Tree"-a replica of a pomegranate tree in whose branches visitors are meant to leave notes about what the word "emancipation" means to them, interactive technology such as a "digital Talmud" and an "open keyboard," contemporary art, and special exhibitions, the museum covers more than two thousand years of Jewish history. ${ }^{52}$ It also features non-memorial spaces such as an exhibition space designed specifically for children, a glass courtyard designed for special events, an outdoor garden, a restaurant, and a tree-lined outdoor space. The museum is meant to be a Jewish museum, not a Holocaust museum, though its 
architectural conceit might suggest otherwise. It is not meant to give visitors a "sickening" or "horrifying" experience about the Holocaust but rather to enmesh German Jewish history and "a broader German national narrative culminating in a more ethnically diverse and tolerant present. ${ }^{, 53}$ One is meant to notice the building and to notice its radical architecture, but one is also meant to experience the museum as a locus of moral and social improvement in modern Germany and as a way to make visible Berlin's past. ${ }^{54}$ As the scholar of Jewish culture Barbara Mann explains, the museum's architecture situates it within the wider context of what she calls "the new global Jewish architecture. ${ }^{, 55}$ Here Mann refers to the group of Jewish architects who have designed or are designing some of the most significant buildings in the world since the Holocaust. These architects include Daniel Libeskind (the Jewish Museum Berlin and the 9/11 memorial site), Peter Eisenmann (the Memorial to the Murdered Jews of Europe in Berlin) ${ }^{56}$ and Frank Gehry (the Guggenheim Museum in Bilbao, Spain). Mann argues that the fragmented, deconstructed, viscerally evocative post-Holocaust architectural style used in these buildings is best demonstrated in Libeskind's work for the Jewish Museum Berlin. It resembles, Mann writes, a "scar on the urban landscape" that "keenly depicts the wrenching absence of Jewish life in Berlin, as well as the sharp degree to which humanity had devolved during the Shoah. ${ }^{.57}$ The Jewish Museum Berlin's jarring architectural presence in the midst of an active, urban landscape infuses the building with an impact and a distinctiveness not found elsewhere in the world. The scholar of German-Jewish history Cary Nathenson argues that:

the Jewish Museum Berlin is one of the most important German cultural institutions today... [and] the most significant Jewish cultural institution in 
Germany right now [2013]. The museum's unique mission of documenting and representing two thousand years of German-Jewish history and culture means that the Jewish Museum Berlin is playing a forceful role in defining that culture. Its sheer popularity - it is usually among the top five in attendance for Berlin museums - gives it the loudest popular voice in the discussion of what is German-Jewish culture and history. ${ }^{58}$

Here Nathenson attests to the museum's role in defining what is evidently an ongoing process in Germany today: the defining of the relationship between Germany, its history, and Jewish life and culture there. Despite the presence of countless other Holocaust memorials in Berlin — the Book Burning Memorial at Bebelplatz (1995), the Memorial to the Murdered Jews of Europe (2005), the Memorial for the Nazi-Era Persecution of Homosexuals (2008), and the Sinti and Roma Memorial (2012) — the Jewish Museum Berlin has become an unusual, necessary, and attractive museum for visitors from around the world. Between its opening on September 9, 2001 and its tenth anniversary in September 2011, the museum had over 7,220,000 visitors from forty countries. ${ }^{59}$ The sociologist Irit Dekel describes the engagement in and attraction to this memorial environment as the "practice of memory tourism... [that] is closely linked both to the history of Berlin and to exhibitionary complexes in and around Berlin." ${ }^{, 60}$ Even though the Jewish Museum Berlin stands out radically from its surroundings and is vastly different in size, scope, and appearance from the many Holocaust monuments in Berlin, it is still part of the practice of memory tourism and part of Berlin's memorial topography. Unlike Yad Vashem, which is integrated so thoroughly into the fabric of Jewish life and history in Israel, the Jewish Museum Berlin is not integrated; rather, it stands apart from its surroundings, attempting to explain the historical past while creating a present 
understanding of it and perhaps implying that no matter how many Holocaust memorials Germany builds, the subject will always be held at arm's length.

\section{Conclusion}

As this chapter demonstrates, Yad Vashem and the Jewish Museum Berlin are very different despite the fact that they do have common features: they each exhibit artifacts, show survivor testimonies, host events, provide educational programming, and chronicle Holocaust history. Given that all Holocaust museums share these features, it is the museums' distinctiveness individually and in relation to each other that merits examination. Wheras Yad Vashem is located in a country whose population is $42.9 \%$ Jewish, the Jewish population of Germany is only $0.9 \%$--a difference of 5,782,100 Jews. ${ }^{61}$ Whereas Yad Vashem is located in a natural setting outside the city, the Jewish Museum Berlin is located in an urban environment. Whereas Jewish life in Israel is vibrant and active, Germany is still discerning its relationship to Jewish life and culture there. Whereas Yad Vashem ultimately releases the visitor into a glorious panoramic view of Israel, the Berlin museum ends with a final exhibition entitled "Jewish Childhood and Youth in Germany, Australia, and Switzerland since 1945," which German Studies scholar Jennifer Hansen-Glucklich describes as follows:

It [the exhibit] appears in a green-carpeted, green-walled room filled with poles, on top of which sit white boxes lit from within. Each of the boxes displays photographs of Jewish individuals and families who live in German-speaking countries. Using the supplied headphones, visitors can listen to their stories in German or English. Written in large letters on the first box are the words, So einfach war das (It was as simple as that). The message is that life continues for Jews in German-speaking countries and that a better future is already in progress. It presents a positive, future- 
oriented multicultural ideology because the Jewish German, Austrian, and Swiss individuals in this exhibit are citizens who are successfully integrated into their countries. Their narratives appear to offer a resolution to the problem of how to retroactively integrate Jews into Germanspeaking countries. This exhibit completes the process by which visitors are initiated into a political and social consciousness based on the tolerance of ethnic and religious diversity, the support of minority rights, and the promotion of Germany as an emerging multicultural society. ${ }^{62}$

A visit to Yad Vashem culminates in a triumphant moment of release and reassurance as one looks out over the topography of Israel, knowing now that the future lies in this vast expanse of land, life, and tradition. A visit to the Jewish Museum Berlin concludes with an attempt to show that German society has been transformed since the Nazi era to a progressive, diverse environment in which Jews can thrive.

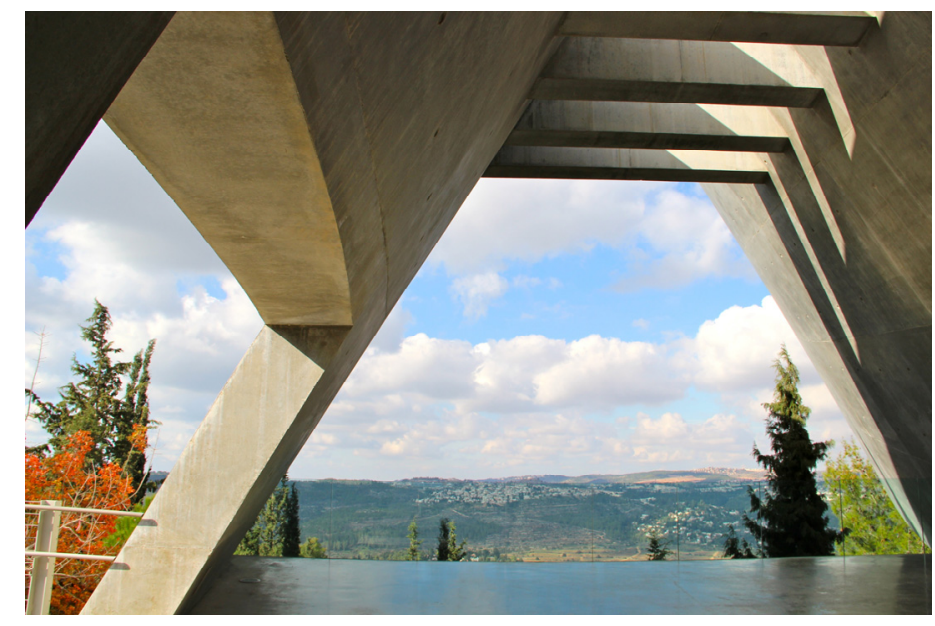

Hansen-Glucklich, Jennifer. Yad Vashem, Jerusalem.

The differences between these two museums illustrate a key point in the study of Holocaust museums: that even though they may all include some of the same historical information and rely on similar museological practices in the creation of their narratives, 
each is a product of its particular local and national needs, its architect, and its role in Holocaust history. The next chapter of this dissertation demonstrates that this statement holds true even for Holocaust museums that are all located in one country, the United States, for after the war, when survivors immigrated to places as different as New York and Tel Aviv or Los Angeles and Jerusalem, they brought with them all of their wartime experiences and merged those with the culture and climate of their new, adopted cities and countries. An entirely new type of Jewish life began at this point, at this time of reconfiguration and redefinition for Jewish communities around the world. Also new was the need to address the memory of an atrocity against the Jews that the modern era had never known before.

\footnotetext{
${ }^{1}$ Kendall R. Phillips and G. Mitchell Reyes, eds., Global Memoryscapes: Contesting Remembrance in a Transnational Age (Tuscaloosa: University of Alabama Press, 2011), 13.

${ }^{2}$ James Young, The Texture of Memory: Holocaust Memorials and Meaning (New Haven and London: Yale University Press, 1993), 5.

${ }^{3}$ James Young, At Memory's Edge: After-Images of the Holocaust in Contemporary Art and Architecture (New Haven and London: Yale University Press, 2000), 92-93.

${ }^{4}$ James Young, The Art of Memory: Holocaust Memorials in History (New York and Munich: Prestel, 1944), 23.

${ }^{5}$ Young, Art of Memory, 25.

${ }^{6}$ Dalia Ofer chronicles the pre-Yad Vashem forms of Holocaust commemoration in her essay "We Israelis Remember, But How? The Memory of the Holocaust and the Israeli Experience." Israel Studies, Volume 18, No. 2, Summer 2013, 74. These forms include: in 1946 the establishment of Kibbutz Yad Mordechai in, to honor Mordechai Anielewicz, the leader of the Warsaw Ghetto Uprising; in 1947, the designation of the tenth of Tevet to the commemoration of the Holocaust; in 1949, the creation of the Forest of the Martyrs in the Judean Hills; in 1950, the dedication of Martef HaShoah, a memorial and prayer corner in King David's tomb on Mt. Zion; and in 1951, the creation of the Memorial Day for the Holocaust and the Ghetto Uprising on the $26^{\text {th }}$ of Nisan. Looking even more broadly at Israel's memorial landscape, the anthropologist Harvey E. Goldberg writes that, as of 2003, "Yad Vashem is perhaps the most effective and meaningful instance in Israel of calling upon memory in relation to collective identity, but the Israeli landscape
} 
is marked by hundreds of other graves, monuments, and memorial sites from different periods, representing a range of views about what being Jewish and Israeli signifies..." (Jewish Passages: Cycles of Jewish Life, Berkeley, Los Angeles, London: University of California Press, 2003, 223). Goldberg's assessment of Yad Vashem here remains true as of this writing, in 2013, and it points out one of the defining characteristics of Yad Vashem, that it is deeply comingled with countless other memorials and with the historical, cultural, and religious life of its home country.

7 Dalia Ofer, "The Strength of Remembrance: Commemorating the Holocaust During the First Decade of Israel," Jewish Social Studies, Volume 6, Number 2, Winter 2000 (New Series): 33.

8 Paul Williams, Memorial Museums: The Global Rush to Commemorate Atrocities (Oxford and New York: Berg, 2007), 6. Political science scholar Raul Hilberg underscores the relationship between Zionism amongst Holocaust survivors and the future state of Israel. In his book, Perpetrators, Victims, Bystanders: The Jewish Catastrophe 1933-1945 (HarperCollinsPublishers, 1992), he writes that the presence of survivors in German and Austrian DP camps between 1945 and 1948 "heated the sentiment of the Western Jewish communities, particularly in the United States, to a boiling point. Anti-Zionism in the Jewish community collapsed, and a consensus that Jewry, abandoned during the war had to have a home of its own crystallized overnight. It was this pressure that induced the British government to abandon Palestine, and Israel was born, on May 14, 1948, three years almost to the day after the end of the catastrophe" (191). The indelible relationship between Holocaust survivors, the State of Israel, and Holocaust remembrance was to be acknowledged permanently in the form of Yad Vashem.

${ }^{9}$ Lucy S. Dawidowicz, The Holocaust and the Historians (Cambridge, Massachusetts and London, England: Harvard University Press, 1981), 127.

${ }^{10}$ Isabelle Englehardt, A Topography of Memory: Representations of the Holocaust at Dachau and Buchenwald in Comparison with Auschwitz, Yad Vashem, and Washington, D.C. (Bruxelles: Peter Lang, 2002), 183.

${ }^{11}$ Dalia Ofer, "We Israelis Remember, But How? The Memory of the Holocaust and the Israeli Experience," Israel Studies, Volume 18, No. 2 (Summer 2013): 76.

${ }^{12}$ Saul Friedländer, "Memory of the Shoah in Israel: Symbols, Rituals, and Ideological Polarization," in The Art of Memory: Holocaust Memorials in History, ed. James Young (The Jewish Museum, New York: Prestel, 1994), 149.

13 Jette Sandahl, Director of the Museum of Copenhagen, characterizes museums' relationships with their local and regional environments as "self-portraits." In her article, "Disagreement Makes Us Strong?" (Curator: The Museum Journal, Volume 55, Number 4, October 2012: 467), she writes: "Inevitably, museums function as self-portraits of a nation, a region, or a city. They invent, define, delineate, build, and disseminate identities...they tend to be characteristic of an era, bearing the values and forms and shapes of the knowledge and ways of thinking of their times. At any given point in time, museums, in fundamental ways, reflect the values and world views of their surrounding society." This vocabulary of self-portraiture accurately describes the relationship between Yad Vashem, the new state of Israel, and the slowly emerging post-Holocaust narrative taking shape there. 
${ }^{14}$ Shaul Kelner, Tours That Bind: Diaspora, Pilgrimage, and Israeli Birthright Tourism (New York and London: New York University Press, 2010), 118.

${ }^{15}$ Kelner, Tours That Bind, 118.

${ }^{16}$ Kelner, Tours That Bind, 132.

${ }^{17}$ Kelner, Tours That Bind, 100.

${ }^{18}$ Tom Segev, The Seventh Million: The Israelis and the Holocaust (New York, New York: Hill and Wang, 1993).

19 Segev, Seventh Million, 422.

20 Segev, Seventh Million, 423.

${ }^{21}$ Omer Bartov, "Chambers of Horror: Holocaust Museums in Israel and the US," Israel Studies. Volume 2, No. 2 (1997): 67.

${ }^{22}$ Charles S. Lieberman and Eliezer Don-Yehiya, Civil Religion in Israel (Berkeley, Los Angeles, London: University of California Press, 1983), 9.

${ }^{23}$ Gavriel D. Rosenfeld, Building After Auschwitz: Jewish Architecture and the Memory of the Holocaust (New Haven and London: Yale University Press, 2011), 260.

${ }^{24}$ Rosenfeld, Building After Auschwitz, 260.

${ }^{25}$ Rosenfeld. Building After Auschwitz, 260.

26 Williams, Memorial Museums, 33.

${ }^{27}$ Tim Cole, Selling the Holocaust: From Auschwitz to Schindler-How History is Bought, Packaged, and Sold (New York: Routledge, 2000), 130.

${ }^{28}$ Simon Goldwill., Jerusalem: City of Longing (Cambridge, Massachusetts and London, England: The Belknap Press of Harvard University Press, 2008), 328-329.

29 The "new" Yad Vashem's emphasis on architectural distinctiveness — as opposed to its early attempts to blend in with its environment - is what Barbara Kirshenblatt-Gimblett asserts is a museological shift. In her essay about the South African Museum (a science museum in Capetown), "Exhibitionary Complexes," she writes that there is "a critical shift from an informing museology (the exhibit as a neutral vehicle for the transmission of information) to a performing museology (the museum itself is on display)" (Museum Frictions: Public Cultures/Global Transformations, eds. Ivan Karp et al. (Durham and London: Duke University Press, 2006), 41). Holocaust museum architecture such as that of Yad Vashem, the Berlin Jewish Museum, and the United States Holocaust Memorial Museum treats the museum itself as an object of display, not just as a container for information.

${ }^{30}$ Ariella Azoulay writes about the role of Yad Vashem in defining the contours of Israeli public space in her essay "With Open Doors: Museums and Historical Narratives in Israel's Public Space," in Museum Culture: Histories Discourses Spectacles," eds. Daniel J. Sherman et al. (Minneapolis: University of Minnesota Press, 1994), 99. She writes that since the establishment of Yad Vashem, other museums, memorials, cultural institutions, and groups have developed and have participated in the shaping of museological and historical narratives in Israel. The proliferation of such groups, she says, has allowed them to shape too how Israel expresses and narrates its past.

${ }^{31}$ Edward Rothstein, "Holocaust Museums In Israel Evolve," New York Times, accessed August 25, 2013, http://www.nytimes.com/2012/09/05/arts/design/israels-holocaustmuseums-evolve-in-message-and-methods.html?pagewanted=all\&_r=0.

${ }^{32}$ Svetlana Boym, The Future of Nostalgia (New York: Basic Bookss, 2001), 175. 
${ }^{33}$ Michael Z. Wise, Capital Dilemma: Germany's Search for a New Architecture of Democracy (New York: Princeton Architectural Press, 1998), 89.

${ }^{34}$ Lisa Saltzman, Anselm Keifer and Art After Auschwitz (Cambridge, England: Cambridge University Press, 1999), 7.

35 Elisabeth Domansky, "A Lost War: World War II in Postwar German Memory," in Thinking About the Holocaust: After Half a Century, ed. Alvin Rosenfeld (Bloomington and Indianapolis: Indiana University Press, 1997), 239-140.

${ }^{36}$ In his book, Germany as a Culture of Remembrance: Promises and Limits of Writing History (Chapel Hill: University of North Carolina Press, 2006), the historian Alon Confino writes about Germany's complicated relationship with its Nazi past. Confino explains that while repression and denial of this past certainly did exist, it is more accurate to say that in Germany after World War II, "silence and expression coexisted in ambiguous, multiple ways" (238). The German social-psychologist Gudrun Brockhaus writes about this "silence," arguing that for most Germans, there was a postwar "identity crisis which was sparked by total defeat, by the victory of the hated enemy and by the radical collapse of delusions of greatness" concomitant with shame, guilt, embarrassment, and "feelings of inadequacy" ("The Emotional Legacy of the National Socialist Past in Post-War Germany," in Memory and Political Change, eds. Aleida Assman and Linda Shortt, Palgrave Macmillan: 2012, 34-35). Germans felt it best to suppress and "block" any emotional response to the postwar revelations about National Socialism. The existence of the Jewish Museum Berlin is thus a modern example of how vastly different "expression" is manifest in Germany society today, of how the period of "silence" has ended. Confino adds to this picture of a modern, expressive Germany when he explains that "in the modern world, tourism has become a fundamental social and cultural practice by means of which people construct ideas about the self, society, nation, the past, and others" (252). As a popular tourist destination for visitors within Germany and from abroad, the Jewish Museum Berlin participates in and influences the construction of ideas as Confino describes.

37 James Young, At Memory's Edge: After-Images of the Holocaust in Contemporary Art and Architecture (New Haven and London: Yale University Press, 2000), 184.

${ }^{38}$ Irit Dekel, "Mediated Space, Mediated Memory: New Archives at the Holocaust Memorial Berlin," in On Media Memory: Collective Memory in a New Media Age, eds. Motti Neiger et al. (Palgrave Macmillan: 2011), 266.

${ }^{39}$ Here I am culling from the work of multiple scholars: Michael Blumenthal, ed., Discovering the Jewish Museum Berlin (Stiftung Jüdisches Museum Berlin, 2001); Peter Chametzky, "Not What We Expected: The Jewish Museum Berlin in Practice," museum and society, 6(3) 196216-245, 2008; Daniel Libeskind, Daniel Libeskind: The Space of Encounter (New York, New York: Universe Publishing, 2000); “Judisches Museum Berlin: Zwei Jahrtausende Deutsch-Judische Geschichte," found at www.jmberlin.de; Rose-Carol Washton Long et al., Jewish Dimensions in Modern Visual Culture: antisemitism, assimilation, and affirmation (Hanover and London: University Press of New England, 2010); and Gavriel D. Rosenfeld, Building After Auschwitz: Jewish Architecture and the Memory of the Holocaust (New Haven and London: Yale University Press, 2011). 
${ }^{40}$ James E. Young, At Memory's Edge: After-Images of the Holocaust in Contemporary Culture (New Haven and London: Yale University Press, 2000).

${ }^{41}$ Jennifer Hansen-Glucklich, "Holocaust Memories: Visuality and the Sacred in Museums and Exhibits" (PhD diss., University of Virginia, 2011), 28.

42 Jewish Museum Berlin, "The History of the Origins of the Jewish Museum Berlin," accessed August 16, 2013, http://www.jmberlin.de/main/EN/04-About-The-Museum/02History-Museum/00-founding-museum.php.

${ }^{43}$ Jewish Museum Berlin, Discovering the Jewish Museum Berlin (Berlin: Stiftung Jüdisches Museum Berlin, 2001), 1.

${ }^{44}$ According to Jewish historian Ruth Gay, there is still a sense of this former ugliness in Germany today. She writes, "Germany a half-century after the end of World War II is filled with echoes. Voices, images, languages ricochet across time, arousing unexpected and profound feelings. When Jews in Germany look back on that half-century, they find it hard to recognize their earlier, displaced, anxious selves in the confident, wellorganized community they have built" (Safe Among the Germans: Liberated Jews After World War II, New Haven and London: Yale University Press: 2002, 252). The Jewish Museum Berlin must attend to these echoes from the past that Gay describes while also acknowledging a new generation of modern German citizens.

45 James Young, "Daniel Libeskind's Jewish Museum in Berlin: The Uncanny Arts of Memorial Architecture," Jewish Social Studies, Vol. 6 No. 2, (Winter, 2000): 2.

${ }^{46}$ Liliane Weissberg, "Memory Confined," in Cultural Memory and the Construction of Identity, eds. Dan Ben-Amos et al., (Detroit: Wayne State University Press, 1999), 48.

${ }^{47}$ Daniel Libeskind, Daniel Libeskind: The Space of Encounter, (New York, New York: Universe Publishing, 2000), 23.

${ }^{48}$ Rose-Carol Washton Long, et al., Jewish Dimensions in Modern Visual Culture: antisemitism, assimilation, and affirmation, (Hanover and London: University Press of New England, 2010), 291.

${ }^{49}$ Editors of the $P A J$, "Berlin's New Jewish Museum: An Interview with Tom Freudenheim," PAJ: A Journal of Performance and Art, Vol. 22, No. 2, Berlin, (May, 2000): 65 .

${ }^{50}$ One example of this is the 28,000 Stolpersteine, or "stumbling blocks," that are located throughout Berlin, in 580 German cities, and in nine other countries. Artist Gunter Demnig designed the flat brass-covered stone plaques, which are installed in the sidewalk in front of the last known residence of Holocaust victims prior to their deportation. On each plaque is written the name and fate of the victim. The plaques are meant to serve as unavoidable reminders of those who suffered and died during the Holocaust. Another powerful yet more localized memorial in Berlin is the Memorial to the Murdered Jews of Europe, which is situated between the Brandenburg Gate and the Potsdamer Platz- two Berlin landmarks located within one mile of each other-and which opened to the public on May 10, 2005. The architect for the memorial, the American Peter Eisenman, designed a memorial composed of 2,700 concrete slabs arranged vertically on 19, 000 square meters of undulating ground. Due to this undulation, from the outside of the memorial the stones take on a wave-like form. The memorial site also includes an information center, which documents the history of Holocaust-era persecution and destruction of people and families during the war. (See "Stolpersteine: The World's 
Largest Project of Art and Commemoration," accessed September 15, 2013, http://www.stiftung-denkmal.de/en/home.html.)

51 In his book Present Pasts: Urban Palimpsests and the Politics of Memory, the German literary scholar Andreas Huyssen explains that Libeskind's use of voids in the museum's architecture render the museum's architecture as "script," in other words: as the creator of a certain narrative. Huyssen continues, explaining that the museum "building itself writes the discontinuous narrative that is Berlin, inscribes it physically into the very movement of the museum visitor, and yet opens a space for remembrance to be articulated and read between the lines" (Stanford, California: Stanford University Press, 2003, 69). In its carefully coordinated interplay between city, architecture, and visitor, the Jewish Museum Berlin becomes a powerful metaphor for the city's legacy of absence; as Huyssen writes, "the absence of Berlin's Jews, most of whom perished in the Holocaust" (Present Pasts 68).

52 Jewish Museum Berlin, Discovering the Jewish Museum Berlin (Berlin: Stiftung Judisches Museum Berlin, 2001).

53 Peter Chametzky, "Not What We Expected: The Jewish Museum Berlin in Practice," museum and society, Nov. 2008, 6(3) 196216-245 (2008): 217.

54 Andreas Hussen writes about the notion of making visible Berlin's past and the idea of a city as an historical text in his book Present Pasts: Urban Palimpsests and the Politics of Memory (Stanford, California: Stanford University Press, 2003). He writes that "there is perhaps no other major Western city that bears the marks of twentieth-century history as intensely and self-consciously as Berlin. This city text has been written, erased, and rewritten throughout that violent [twentieth] century, and its legibility relies as much on visible markers of built space as on images and memories repressed and ruptured by traumatic events" (51-52). In viewing the city as a text, Huyssen describes the way that Berlin has had to reinvent itself after the Holocaust and create a new narrative that includes tangible signs of both its reparations and its memories.

55 Barbara Mann, Space and Place in Jewish Studies (New Brunswick, New Jersey, and London: Rutgers University Press, 2012), 130.

56 Completed in 2005, the Memorial to the Murdered Jews of Europe covers more than five acres in central Berlin and is comprised of over 2,700 gray stone blocks of varying sizes organized in rows on a grid. Visitors may enter the memorial and wander amongst the stones, which grow taller the further one proceeds toward the center. An underground visitors' center containing a small museum is located in the southeast corner of the memorial. Overall, the memorial has earned good reviews from scholars and critics, but there are some concerns about the abstract nature of the memorial. In an article in the New York Times written two days before the unveiling of the memorial to the public, Nicolai Ouroussoff reports that it "is able to convey the scope of the Holocaust's horrors without stooping to sentimentality - showing how abstraction can be the most powerful tool for conveying the complexities of human emotion," and he later adds that "the quiet abstraction of the memorial - its haunting silence and stark physical presencepsychically weave the Holocaust into our daily existence in a way that the painstaking lists at the information center cannot. It memorializes past sufferings but also forces us to acknowledge that history's relevance today" (Nicolai Ouroussoff, New York Times, "A Forest of Pillars, Recalling the Unimaginable," May 9, 2005). Despite this positive 
appraisal of the memorial's "abstraction," however, it has also received criticism for the same. The American First Lady Michelle Obama's recent visit to the memorial along with her daughters drew recent attention to it. Liam Hoare, a foreign affairs writer for the Forward and the Jewish Chronicle, writes that even though the memorial is "indeed a testament to the willingness of the Berlin authorities to very visibly place the memory of murdered Jews at the centre [sic] of city life... as a site of remembrance, [it] can be said to be failing" because it is "only a memorial...for those who want it to be" ("A Bittersweet Holocaust Memorial in Berlin," The Forward, accessed August 25, 2013, http://blods.forward..com/forward-thinking/179059/a-bittersweet-holocaust-memorial-inberlin/). The very abstraction that makes the memorial so powerful also makes it difficult to tell what the memorial is memorializing. The New Yorker movies editor and author of the magazine's cinema and culture blog Richard Brody describes this problem succinctly, writing that "without [the] title, it would be impossible to know what the structure is meant to commemorate; there's nothing about these concrete slabs that signifies any of the words of the title [of the memorial], except, perhaps, "memorial"' (Brody, "The Inadequacy of Berlin's 'Memorial to the Murdered Jews of Europe," July 12, 2013, (http://www.newyorker.com/online/blogs/movies/2012/07/the-inadequacy-of-berlinsmemorial-to-the-murdered-jews-of-europe.html). Overall, the criticism is that the memorial does not acknowledge didactically enough its subject matter, leaving the meaning of the sea of rectangular monoliths open to interpretation and in reliance solely on the viewer's knowledge base.

${ }^{57}$ Mann, Space and Place, 133.

${ }^{58}$ Cary Nathenson, "Chrismukkah as Happy Ending?- The Weihnukka Exhibition at the Jewish Museum Berlin as German-Jewish Integration Fantasy," Journal of Jewish Identities, January 2013, 6 (1): 62.

59 "Press Information: 6 September 2011," "Looking Ahead-Where Does the Jewish Museum Berlin Stand on Its $10^{\text {th }}$ Anniversary," Jewish Museum Berlin, accessed August 28, 2013, http://www.jmberlin.de/main/EN/06-Press/01-Press-Releases/Press-Releases2011/2011_09_06a.php.

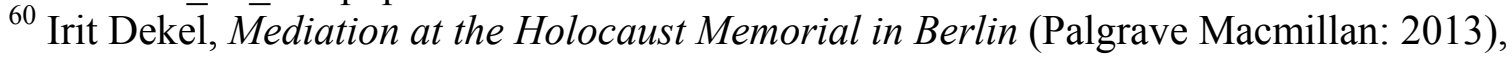
25 .

61 "Jewish Population of the World," accessed September 15, 2013, http://www.jewishvirtuallibrary.org/jsource/Judaism/jewpop.html.

62 Jennifer Hansen-Glucklich, e-mail to the author, August 28, 2013. 


\section{CHAPTER THREE: HOLOCAUST MUSEUMS IN THE UNITED STATES}

The previous chapter examined different kinds of memorials and documented the development of two of the world's most significant Holocaust museums, Yad Vashem and the Jewish Museum Berlin, each of which arose in a starkly different context from the other. This chapter describes the historical events and cultural climate changes that led to Holocaust history's entering the public sphere. It also presents yet another distinctive context for the development of Holocaust museums - the context of the United States, a country that only became directly involved in World War II after the Japanese attack on Hawaii's Pearl Harbor on December 7, 1941, well after the war had begun in Europe.

Unlike Israel, which developed plans for a Holocaust museum in the early 1950s, the first major Holocaust museum in the United States, the United States Holocaust Memorial Museum in Washington, D.C., did not open its doors until 1993-almost fifty years after the end of World War II. The United States did serve as a safe haven for refugees after the Holocaust, but its national agenda at the time focused on the Cold War, not on statehood, as in Israel, or on rebuilding, as in Germany. Eventually, though, the country's focus did turn more toward the Holocaust, especially in the years leading up to the completion of the Holocaust Memorial Museum and after.

Since 1993, more than fifteen Holocaust museums and dozens of Holocaust memorials and centers for study have been built in the United States in cities ranging from San Antonio to Detroit to Miami. The focus of this chapter, and in the dissertation as a 
whole, is on three of the United States museums: the Holocaust Memorial Museum mentioned above, the Los Angeles Museum of the Holocaust, and the Illinois Holocaust Museum \& Education Center in Skokie, Illinois. The Holocaust Memorial Museum is discussed first and at length, for it was and is to this day the most hotly debated, wellfunded, and frequently-visited Holocaust museum in the country. It is also the museum that has garnered the most scholarly analysis and the most press. The Illinois Museum and the Los Angeles museum are roughly the same age, having opened their doors in 2009 and 2010, respectively, and each is the new, relocated iteration of its much smaller predecessor. This chapter offers thorough descriptions of the three museums, with a special emphasis on articulating the historical backdrop against which each museum came into being and on the distinctive exterior and interior elements of each museum. The goal of this chapter is to present each museum in its own context while offering the reader a thorough understanding of the museums' architecture, particular challenges, and exhibitions.

\section{Turning Points}

After immigrants settled in the United States and began to integrate into American culture and American Jewish life, there were several turning points at which American Jewry and its approach to the Holocaust changed significantly. It is important to chronicle these moments, for they 1) demonstrate the attitudes, interests, and virtues of the nation in the post-war years and 2) indicate that Holocaust museums did not arise in the United States in a vacuum: the cultural and political shifts of the country and events abroad that affected the Jewish community in the United States had a significant 
influence on the development of the museums. As this section of the chapter will try to show, the first few decades after the Holocaust did not see the end to war and sociocultural upheaval — quite the opposite. It is against the backdrop of this turmoil that the first Holocaust museum in the United States came into being.

The first major post-war turning point came in the 1950s, during which time Holocaust survivors and other immigrants from Eastern Europe began to have a significant effect on American Judaism. As the historian Jonathan Sarna writes, the immigrants" "memories, commitments, and collective sense of obligation to those who had not survived set the stage for developments that would transform all of American Judaism...for decades to come." Their "commitments" gave rise to an unprecedented level of interest in and dedication to Jewish education of all kinds, so the 1950s saw the creation of Jewish day schools, supplementary school programs, and the creation of Jewish institutions of higher learning. There was also a renewed interest in Jewish theology, Jewish religious thought, and Bible study. ${ }^{2}$ No matter how different individual Jews were from each other, their collective interest in the future of Judaism united them in pursuit of a strong, vibrant American Jewish religious life. The immigrants' focus on memorializing the friends, family, and communities they had lost during the Holocaust also bound them together. That said, Holocaust remembrance was still only at the periphery of American consciousness. It was not for several more decades, until American Jews had navigated other events and societal changes, that the Holocaust became central to American Judaism rather than peripheral. 
The next shift took place when a series of events in the 1960s brought significantly more attention to the Holocaust in the United States. The initial event was the capture of Adolf Eichmann, a key figure in the development of the Final Solution, and his ensuing 1961 trial in Jerusalem. German-Jewish intellectual and writer Hannah Arendt's controversial book on the subject, Eichmann in Jerusalem, ${ }^{3}$ also brought significant attention to the subject of the Eichmann trial upon its release in 1963. In addition to all of the turmoil and debate of the early 1960s, in 1965 the meeting of the Second Vatican Council resulted in Pope Paul VI's releasing the papal encyclical "Nostra Aetate" or "In Our Time," which the Vatican officially describes as its "Declaration on the Relation of the Church to Non-Christian Religions." The encyclical was considered revolutionary for the way in which it affirmed a future of good relations between Catholics and Jews and especially for its statement against the charging of Jews with deicide. In 1963 the socalled "Auschwitz Trials" saw the trial of twenty former Nazis in West Germany. The early-to-mid 1960s, therefore, marked a time for Jews around the world to feel finally a sense of justice.

Another set of changes took place in the United State during the late 1960s, when the civil rights movement was of central concern. Even though this social movement involved the fight for the rights of black Americans and was not directly about Jews per se, American Jews became deeply committed to this fight for human rights. As Rabbi Joachim Prinz argued at the time, the Holocaust was a "universal" and "Jewish reference point, providing a specifically Jewish rationale for involvement in the civil rights movement. ${ }^{4}$ Jewish immigrants felt that their experience during the Holocaust, combined 
with the Jewish religious emphasis on social justice, obligated them to join their fellow Americans who were fighting, like they had in Nazi-occupied Europe, for equal rights and freedom from oppression. Rabbi Prinz had been expelled from Germany in 1937 for speaking out against the Nazis, and now in America, he spoke out against racism and prejudice. He helped organized the famous 1963 March on Washington, a political rally that focused on drawing attention to discrimination against African-Americans; his speech on the day of the march directly preceded the Reverend Martin Luther King, Jr.'s "I Have a Dream Speech." Prinz's sentiment, that "silence" is the most "disgraceful, shameful, tragic" problem in the face of injustice, resonated with black Americans, white Americans who supported the civil rights movement, and Jewish Americans alike. When Prinz's colleague, Rabbi Abraham Joshua Heschel, participated in the 1965 walk for voting rights from Selma to Mongomery, Alabama, he further cemented the link between Jewish Americans and their commitment to human rights and social activism. Heschel was also vehemently opposed to the Vietnam War, in which American troops began to participate in 1965. Thousands of American soldiers died in what many, including Heschel, thought was a purely destructive endeavor that resulted in the deaths of thousands of Vietnamese civilians - a parallel to the slaughter of innocent Jewish civilians during the Holocaust that was impossible for American Jews to ignore

On the political level, architectural historian Gavriel D. Rosenfeld explains that "in the United States, fears of a 'second Holocaust' during the Arab-Israeli wars of 1967 and 1973, as well as worries of accelerating Jewish assimilation, persuaded many American Jews - especially those in institutional leadership positions - to stop downplaying the 
Holocaust and instead invoke its legacy as a way to garner sympathy for Israel and shore up flagging Jewish group solidarity." Jewish community leaders were committed to and interested in Holocaust remembrance but not purely for the sake of remembrance itself. They had other concerns too, namely about the safety and sanctity of Israel and about the evolution of Jewish life in America. ${ }^{6}$ Jacob Neusner defines the 1967 war as the event that catalyzed the "re-ethnicization" of American Jews, for in the weeks preceding the war, Jews heard Arabs vow to "drive Israel into the sea," talk that caused the second generation of American Jews to understand the fear that their parents and grandparents had felt in Nazi-occupied Europe before them. ${ }^{7}$ In addition, the "rise of multiculturalism [in America]... also promoted Jewish interest in the Holocaust, for it enabled Jews to find common cause with other minorities in American society who were seeking redress for historical injustices." ${ }^{\prime}$ The notion of Holocaust remembrance thus fit into a broader, contemporary movement in the United States that the Jewish and non-Jewish public could understand and even embrace.

In addition to all of the factors mentioned above-immigrants' commitment to Jewish education, the civil rights movement, the Eichmann trial, the Auschwitz trials, the Six Day War, and the Vietnam War-there were cultural and political factors also influencing American Jewish thought about the Holocaust in the generation after the war. On the cultural level, the 1970s and 1980s saw a surge of Jewish publications, Jewish scholarship, Jewish theatre groups, and Jewish museums and galleries. ${ }^{9}$ When increased interest in the Holocaust arose against this backdrop of increased interest in Jewish 
subjects and Jewish cultural endeavors, there was thus a context created for attention to Jewish interests and concerns.

A third shift occurred in 1978 when a number of events combined to propel the Holocaust into public conscience inexorably, a year that Edward T. Linenthal calls a "crucial year in the organization of Holocaust consciousness." witnessed the drama unfolding in Skokie, Illinois, as a threatened march by Chicagobased American Nazis brought the principle of free speech into conflict with what seemed to be common decency, the recognition of survivors' feelings. Around the same time, the United States Department of Justice created the Office of Special Investigations (OSI) - "whose purpose was to bring Nazi war criminals living in the United States to trial for the purpose of deportation," ${ }^{11}$ — and thus brought to light the importance of trying and potentially convicting Nazis who had been given refuge in the United States. Also in 1978 the nine-and-a-half hour miniseries, The Holocaust, appeared on NBC on April 1619 to an estimated audience of approximately 120 million, both captivating audiences and drawing critiques that it trivialized the Holocaust. ${ }^{12}$ The film series also prompted some to claim that it "was almost singly responsible for awakening interest among people ignorant of the events [of the Holocaust]."13 Finally, in 1978 President Carter announced plans to create the President's Commission on the Holocaust, moving the Holocaust not only "from the periphery to the center of American Jewish consciousness, but to the center of national consciousness as well." ${ }^{, 14}$ In the space of one year, a new and palpable awareness of the Holocaust was taking place across the country, igniting debates about 
what place the Holocaust should have in American society and about how the Holocaust and its victims should be memorialized.

At the same time, Holocaust remembrance was gaining traction in Western Europe, where "the surging interest in the Holocaust reflected the growing willingness of certain nations, especially West Germany and France, to confront the full dimensions of their behavior during the Second World War." 15 The international stage was set to receive what was about to become a wave of Holocaust remembrance, memorials, and museums, so when twelve of the twenty-four members of the President's Commission ${ }^{16}$ for the planning of a Holocaust memorial museum in Washington, D.C. submitted written comments prior to its first meeting, they wrote that they "envisioned a 'living memorial' that would soon be seen as a facility housing memorial, museum, archive, and educational institute [facilities]. It was clear, however, that commissioners were divided about how to balance Jewish victims with others, whether their focus should be solely on the Holocaust, or whether that event should lead as well to a focus on contemporary genocidal events." ${ }^{17}$ Given the weight and complexity of these issues, it is no wonder that the "living memorial" did not then open until fifteen years had gone by—despite the international and national inclination to build such institutions as Holocaust museums. That said, when the United States Holocaust Memorial Museum opened on April 22, 1993 — with the Simon Wiesenthal Center's then-called "Beit HaShoah/Museum of Tolerance" opening just two months earlier-it was ultimately opening its door to an America caught up in the "ideology of multiculturalism."18 American society was ready 
to embrace diversity, heterogeneity, the subject of universality, and especially the notion of universal human rights.

\section{The United States Holocaust Memorial Museum}

As demonstrated in the previous chapter's discussion of Yad Vashem and the Jewish Museum Berlin, the location of a Holocaust museum is fraught with meaning, and the case is no different in the United States, as this discussion will demonstrate. The United States Holocaust Memorial Museum is located at 100 Raoul Wallenberg Place in Washington, D.C. adjacent to Washington's National Mall, a green space lined with museums and in full view of the Washington National Monument, multiple memorials, and the Capital Building. Its front entrance on $14^{\text {th }}$ Street faces large, white concrete government buildings. The museum's back entrance on $15^{\text {th }}$ Street faces the expansive lawn that is home to the Washington National Monument and that borders the serene Washington Tidal Basin. Beyond the National Monument, one can see the Vietnam Veterans Memorial, ${ }^{19}$ the World War II Memorial, the Reflecting Pool, and the Lincoln Memorial — all of which are famous Washington landmarks in their own right.

USHMM's location next to the mall and in view of these landmarks affords it not only the benefit of being in the heart of Washington tourist traffic but also the respect that many feel a museum of the Holocaust deserves in the nation's capital, ${ }^{20}$ "'thrust[ing] Jewish presence and identity into the American public's awareness... ${ }^{21}$ in a way that had not been done before. ${ }^{22}$ 
The museum's presence on the mall also places it in direct comparison to the Vietnam Veterans' Memorial, which since its dedication in 1982 had "done more to change the direction of [Washington's] memorial landscape" than any other memorial in the cityaccording to art historian Kirk Savage. ${ }^{23}$ The Vietnam memorial memorializes an event that deeply affected American citizens. As Savage explains, the memorial is "radically simplifying and antididactic," whereas the Holocaust Memorial Museum would memorialize the deaths of millions of European Jews, not Americans, and would be "sprawling and didactic."24 The museum, it seemed, would singlehandedly change again the memorial landscape of Washington, D.C., yet in a very different way than the Vietnam memorial had.

On May 11, 1985 the United States Holocaust Memorial Council unveiled its plans for a thirty million dollar, red granite museum that would replace two "red-brick Government buildings" adjacent to the Bureau of Engraving and Printing and open to the public in 1989. ${ }^{25}$ The National Advisory Council on Historic Preservation granted the museum permission to raze the two government buildings, but Representative Sidney R. Yates countered the decision, stating, "I think you should tell me first why you think you need a new building. ${ }^{26}$ Yates argued further, claiming that the brick buildings would be "'symbolic of the buildings the people who endured the Holocaust' were housed in," but council member and co-architect of the museum George Notter explained that the brick buildings were neither large enough nor in good enough condition to be refurbished without prohibitive cost. ${ }^{27}$ The project thus moved forward with its plan to demolish the two original buildings. 
Two years later, in 1987, the New York Times reported that the museum would be a fortyfive to fifty million-dollar limestone and brick building that would open to the public in in $1990 .{ }^{28}$ Its design was to undergo review from the Federal Commission of Fine Arts on May 22, 1987 and from the National Capital Planning Commission in July 1987. Both commissions approved the design with the exception that the museum provide and have approved "a study on the effects of the [museum's] atrium light on the night skyline in the Mall area." ${ }^{29}$ Co-architect James Ingo Freed revised the museum's design, which the Federal Commission of Fine Arts approved on June 19, $1987 .{ }^{30}$ By 1990, however, the museum had not opened, and on April 22, 1990, the New York Times reports that the “one hundred million-dollar" building would be completed in $1993 .{ }^{31}$ The chronic delays and continually mounting costs were due in large part to discord amongst members of the museum's planning council. The council disagreed on many issues: whether the museum should memorialize non-Jews who died in the Holocaust; how "universal" the museum should be; whether to fundraise outside of the Jewish community; whether to allow donors' names on plaques in the museum; whether to use high technology in the museum's permanent exhibition - to name but a few. ${ }^{32}$ The only point on which nearly all of the council members agreed ${ }^{33}$ was that the museum should be a "living" memorial, a memorial that is active, not passive, and that pulses with people, ideas, information, sound, image, and emotion. Ultimately it was toward this end - the creation of a living memorial to the Holocaust — that the commission worked tirelessly and with devotion and sensitivity to the enormous task at hand. 


\section{A) Exterior Elements}

When looking at the Holocaust Memorial Museum and its $14^{\text {th }}$ Street entrance from across the street, the building's limestone façade blends in fairly well with the other large buildings in the surrounding area —unlike Yad Vashem and the Jewish Museum Berlin, which stand out conspicuously from their surroundings. The museum appears to be composed of the same material, and it is the same color. The wall on the left side of the museum's entrance is slightly rounded, and its entranceway is rather large, but overall one does not notice any major difference between this building and the others nearby, an intentional effect designed to help the museum blend into the aesthetics of the buildings in the surrounding area. What cannot be understood from this vantage point, however, is that unlike other museums on the Mall, this museum is not of a celebratory nature. It is meant to house an "intentionally disturbing experience" and in so doing to alter forever the museological landscape of the nation's capital. ${ }^{34}$

\section{B) Interior Elements}

\section{i. The Entrance Lobby and Hall of Witness:}

One way in which the Holocaust Memorial Museum set a precedent for Holocaust museums in the United States is through its use of notable interior structural elements. One example of such a feature is the museum's main hall, the "Hall of Witness." To access the hall, one must first pass through the museum's small lobby, a small, lowceilinged entry space filled with security guards and metal detectors. Other than a wall lined with flags, there is nothing unusual or particularly noticeable about this space other than its obviously high-level security, especially because there is a wall about ten feet 
behind the security area that blocks one's view into the Hall of Witness. After passing through security and walking by the wall of flags and the museum gift shop, however, any impression of smallness or sameness disappears. The Hall of Witness is architecturally renown for its four story-high glass and steel beam ceiling. This ceiling sits atop enormous brick walls laced geometrically with strips of steel. At the back of the Hall is a completely black stone wall with a single quotation written on it: "You are my witnesses" (Isaiah 43:10). The combined effect is startling. The Hall is aesthetically remarkable but not beautiful, as the steel, brick, and black walls sit in tension with the natural light and the soaring ceiling that immediately draw the eye upward, where oddly one can see a glass bridge near the ceiling of the museum and the tiny human forms traversing it.

\section{ii. Footbridges}

USHMM architect James Ingo Freed designed the museum so that footbridges would connect the exhibition spaces, with one of the bridges traversing the Hall of Witness several stories in the air. The footbridges are entirely encased in glass, so one can see out on all sides except for the floor, which is composed of a thick, translucent glass. Here the glass walls of the footbridge are etched with the names of communities that were lost or destroyed completely during the Holocaust. The light that fills the glass footbridge is therefore rendered ironically, for the brightness that would typically hint at hope, relief, and happiness is instead etched with a geography of destruction. In addition, the glass walls of the footbridge do not meet expectations. When looking out a window, one expects to see something, yet when looking out of these windows, one sees only brick 
wall, steel beams, and glass, for the visitor looks out into the interior of the museum, not onto a view. The effect is surprising and disorienting.

About halfway across the bridge, there appears to be a window in the glass - a window amidst a window, so to speak — but it too reveals a surprising view. Here the visitor looks out the "window" to find that she is looking down a long glass and steel-beamed tunnel; one can see all the way to a white wall on the other end of the museum, but nothing else. The tunnel of glass seems to grow more and more narrow as it approaches the wall, directing one's gaze toward nothing but a spot of white wall. A bit further down the footbridge is another similar window, but this time, there is a view when one looks out. From here one can see directly in the Hall of Witness, the museum's main entrance lobby. After so much darkness and so many thwarted attempts at finding a view, the sight of the light-filled lobby takes one aback. The visitors below look small and ordinary — as though they are not in a Holocaust museum but instead anywhere - that one is struck by a feeling of profound distance from what is normal, from what is free.

\section{iii. The Tower of Faces}

Like the footbridges, the "Tower of Faces" is a unique architectural element of the museum that has become one of its most well-known and most unique features. The tower is lined with photographs of people, and it rises so high that it is impossible to see all of the photographs closely. They seem to disappear at the top, as the tower narrows slightly and seems to dissolve into a space high above that is glowing with natural light. A label at the entrance to the tower explains that all of the photographs are of Jews who 
lived in the Lithuanian town of Eishishok and that the photographs come from the collection of Yaffa Eliach, a Holocaust scholar who was born in Eishishok in 1937 and who survived the war in hiding. Unlike many of the photographs found in the museum, the photographs in the Tower of Faces are not gruesome, and they do not depict scenes in which the subjects are frightened and sad. Instead the subjects are participating in the documentation of familiar, happy life events: a group of friends at a summertime picnic, two siblings hugging each other, a mother with a child on her lap, a class in school. The images are both familiar and different: familiar because they capture scenes to which anyone can relate and different because the appearance and clothing of the subjects clearly places them in the distant past. The sheer number of photographs used (hundreds), the height of the tower, and the fact that one enters the tower at several points along one's tour of the museum positions it as one of the most prominent features of the museum. It illustrates in no uncertain terms the magnitude of loss that occurred during the Holocaust, especially once one is at the bottom of the tower and learns that all of the residents of the town died when the Nazis killed every person in every photograph in the tower over the course of two days in 1941; one is told, too, that no Jews live in Eishishok today.

\section{iv. The Hall of Remembrance}

At the end of the museum tour, one begins to pick up the faint smell of smoke wafting through the air as one leaves the amphitheater and the end of the permanent exhibition space. The smell comes from the six-sided Hall of Remembrance, where visitors may light memorial candles, view the eternal flame, and sit quietly under a beautiful, light, 
domed space that offers the time and place for reflection after the long and thoughtprovoking museum experience. Each of the six walls displays a large black panel engraved with the name of a German or Polish concentration camp, and the lighted memorial candles are lined up in front of the panels, where they flicker softly. It is a relief to find this quiet, open place after the cacophony of words, images, and emotions of the previous three floors. The dark red granite floors and natural light diffused through the glass-domed ceiling create a contemplative, serene, warm environment despite the grand scale of the space. Often used for significant public events including presidential speeches, the Hall of Remembrance serves not just as a meaningful interior space but also a notable component of the museum's exterior. One can see the pointed roof of the dome from the street, so even though the grey stone façade of the building may blend in well with its surroundings, the pointed dome articulates architecturally that the building has a distinctive function or meaning, which indeed it does.

\section{v. The Elevators}

To enter the permanent exhibition spaces of the museum, which are located on the upper floors of the building, one must present one's ticket to the guard who monitors the bank of elevators located on one side of the museum. The guard presents each visitor with what looks like a small, gray passport. It is an "identification card" in which one finds biographical information about a person who lived at the time of the Holocaust. With the turn of each page of the passport, one learns more and more about how that person's life unfolded under Nazi persecution. On the last page of each booklet, one learns whether the person survived. 
A volunteer directs visitors to a particular elevator, explains that the elevator will go only to the fourth floor of the museum, announces that each floor addresses a different subject—beginning with the "Nazi Assault," continuing with the "Final Solution" on the third floor, and ending with the "Last Chapter" — and sends the group up with a swift swipe of her identification tag. During the elevator ride to the fourth floor, a short video plays that shows pictures taken at the liberation of the camps along with a male voiceover explaining that what he saw "there" defies description. Equally as grim, the interior of the elevator repeats one of the aesthetic tropes found in the lobby, for it is completely lined with blackened steel. Even the elevator doors are cloaked in this material, creating a seamless and disconcerting effect when the doors are sealed. This elevator does not seem to be purely functional; instead, it seems to have intention, to be preparing the visitor for something that cannot yet be named or understood.

When the elevator doors part, they release visitors into an almost completely dark space. The words THE HOLOCAUST are written in raised capital silver letters on the wall to the right, and a huge, backlit black-and-white photograph dominates the wall directly in front of the visitors who have just stepped off of the elevator. Upon first glance, the photograph appears to be of soldiers looking at a large pile of firewood. If one looks more closely by stepping to within a foot or so of the photograph, one can see that what appears to be firewood is actually a pile of partially burnt human bodies stacked onto a pyre. The label explains that the men in uniform include General Dwight D. Eisenhower and that the photograph was taken during the American liberation of Ohrdruf, a German 
subcamp of Buchenwald concentration camp. To the left of this photograph, a

continuous loop of footage from the liberation of Dachau is shown. This move, ${ }^{35}$ beginning one's journey through the museum with the end of the story rather than with the chronological beginning, offers closure for the visitor, for she knows immediately that the story she is about to hear has an end. That end, however, signifies only a moment in historical time; as the museum demonstrates, for the survivors the Holocaust never does end.

\section{vi. Contemporary Art:}

After walking through the base of the Tower of Faces, as previously described in this chapter, the visitor enters a carpeted stairwell, descends to the third floor of the museum, and enters a white-walled lobby. This lobby has the feel of a modern art museum, with its high ceilings, natural light, gray carpet, benches, and a display of abstract paintings. On one wall, there are three large white rectangular canvases, and on the opposite wall is an equally large white canvas in the shape of a fan. A small panel explains that the 1993 installation by renowned abstract artist Ellsworth Kelly, entitled "Memorial," is made of wood and fiberglass. The airiness of the room and the large, monochromatic shapes are in stark contrast to the dark exhibition space from which one has just emerged, crowded as it is with people, images, information, artifacts, and sounds. The art historian and critic Mark Godfrey writes about USHMM's use of abstract art in an essay called "The Commissions in the United States Holocaust Memorial Museum." Godfrey states that the abstract works "leave one asking, indeed, 'what am I supposed to remember here?"” and he argues that "in revealing this to be such a difficult question, [the art] ruffle[s] the 
smoothness of the very notion of a memorial museum." ${ }^{\text {"36 }}$ The abstract art in the museum does give one pause, for its appearance is puzzling, surprising, and even welcome after the flood of darkness, noise, and information in the first section of the museum. ${ }^{37}$ As Godfrey's question above implies, however, the juxtaposition of the art against the preceding exhibitions prompts one to wonder why the art is there and what one is supposed to think or feel in response to it. This invitation to experience whatever emotion one likes "ruffles" the experience of being in the museum because in other parts of the museum, one's emotional responses to the exhibits are more predictable. When one sees a video from the liberation of Dachau, one is expected to feel horrified. When one sees pictures of a burning synagogue, one is supposed to feel shocked or saddened. The presence of the blank white canvases, however, presents the opportunity for open response and for what the philosopher Nicholas Wolterstorff calls "aesthetic satisfaction," a feeling that "one experiences while engaged in contemplation."38 This aesthetic "satisfaction" need not be equated with joy or happiness; instead, what Wolterstorff means here is that one's reaction to the aesthetic situation resides in contemplation, however dark that contemplation might be in the context of a Holocaust museum. He writes, "I think it is the complex interaction between the aesthetic dimension on the one hand and the moral and religious dimensions on the other that causes our deepest perplexities and our sharpest controversies, ${ }^{, 39}$ and it is just this amalgam of the aesthetic, the moral, and for some visitors, the religious, that can merge during contemplation of the abstract art found in this portion of the museum and in others. The art, so different from the other visual materials found in the museum, invites 
the contemplation upon which the museum relies so that the visitor can merge the different aspects of the museum experience into a cohesive whole.

This pursuit of aesthetic contemplation continues, for after the final Tower of Faces exhibit, there is a series of five square, abstract $1993 \mathrm{Sol}$ LeWitt paintings on the wall there, an installation that LeWitt calls "Consequence." Each contains a gray square lined with black, all of which is encased in a larger square of color: first maroon, then blue, then mustard-yellow, then dark blue, then maroon again. One may sit on the benches in the space, rest, and examine the paintings, which are vastly different from the images and color scheme from which one has just emerged. Also quite different from most other Holocaust museums is the use of contemporary art galleries in the permanent exhibition. Abstract forms ${ }^{40}$ are frequently found in Holocaust memorial sculptures, but contemporary art galleries used in this way and in this setting do represent a departure from the norm.

Even so, as the late Stephen C. Feinstein, founder and director of the Center for Holocaust and Genocide Studies at the University of Minnesota, wrote in his essay "Witness and Legacy," "Art had a lot to do with the Nazi regime and has a logical relationship with the Holocaust, despite the aesthetic and ethical problems that are raised for artists in the aftermath of such horror." ${ }^{, 41}$ Here Feinstein is referring both to Hitler's focus on art during the Nazi era and to postwar visual representations of the Holocaust. He explains that Hitler aspired to be an artist but was denied admission to art school; that Hitler considered modern and abstract art to be "an affront to civilization;" and that he 
had many paintings destroyed as part of his "war on culture."42 Feinstein also describes how "attempts by artists to grapple with the catastrophe that would become the Shoah began in the earliest days of the Nazi regime" and continued in the postwar era, as artists, like writers, poets, filmmakers, and scholars sought to understand and memorialize the catastrophe. When the Holocaust Memorial Museum's use of contemporary art is considered in light of this history, it is not as surprising or puzzling that this form of expression is used there.

\section{vii. Survivor Testimony}

All Holocaust museums incorporate survivor testimony in any number of ways: through live survivor speakers, videos of recorded testimony, and/or print. At USHMM, survivor testimonies ${ }^{43}$ are also incorporated into the museum's permanent exhibitions in multiple ways, two of which are especially compelling: in its exhibition "Voices from Auschwitz" and in its amphitheater at the end of the museum tour. Voices from Auschwitz is an unconventional museum exhibit in that it is meant to be heard, not seen. The title of the exhibit is etched into glass walls that surround a rectangular space made of Jerusalem stone. Visitors sit on benches built into the walls and listen to survivors' voices speaking about their experiences in Auschwitz. There are no photographs or television screens in the exhibition. One is merely meant to listen to the testimonies in what becomes a quiet, intimate setting very different from the more information- and object-driven visual mode of the rest of the museum. There is the sense that one is being spoken to directly and very personally here. 
On the other hand, survivor testimony is presented quite differently later in the museum, for at the very end of the museum tour there is a large Jerusalem-stone amphitheater with a floor-to-ceiling screen onto which is projected the testimony of Holocaust survivor Gerda Weissman Klein and her husband Kurt Klein. A Polish Holocaust survivor of three different slave labor camps, Gerda Klein's testimony is articulate, sensitive, and captivating, as is that of Kurt Klein, a German-born American immigrant who had joined the American military and was in that capacity one of the American soldiers who rescued a group of women who had been abandoned in a small Czechoslovakian village during a death march. Gerda Weissman (Klein) was one of the women in this group, and part of her testimony describes the tragic circumstances of her and Kurt's first meeting in the village. She places a special emphasis on the dignity with which Kurt Klein treated her at the time, holding a door for her and referring to her and the other survivors in her group as "ladies."

The presentation of the testimony on such a large screen compels the visitor to watch for at least a moment, and many visitors do sit on the amphitheater's benches, intending perhaps to watch the testimony in its entirety. More interesting to observe, however, are the visitors who remain standing on the outskirts of the seating area. Many seem stopped in their tracks, drawn into the testimony so deeply that they are unable to move- even to sit down. Though the delivery format is different in this space in the museum and is decidedly more visual than in the more intimately designed Voices from Auschwitz, the effect is similar if not the same: the testimony functions as a one-on-one conversation between the survivor and the visitor to the most superlative degree possible for a 
recorded, not live, testimony. In both testimonial exhibitions cited here, the visitor is literally surrounded by the sound of the survivors' voices; the visitor is enveloped in the survivors' memories. This envelopment occurs not just because the story is compelling or because the speaker is sensitive and articulate but also because there is a quiet intensity that testimony communicates. Holocaust survivor and psychoanalyst Dori Laub writes, "looking backward at my own life, I realize that the most precious possessions I have are my memories."44 Laub's comment here is prescient, for Holocaust museums today are confronting the slow but imminent loss of the survivor population; when the survivors are no longer able to present live testimony in the museums, all that will be left is the memory of them and the recordings of their memories.

\section{viii. Artifacts}

In museums, artifacts are used to tell the story that the museum would like to present, and they are considered what museologist and anthropologist Crispin Paine calls "carriers of memory," or objects that encapsulate memory regardless of whether the visitor experiences the object as part of a personal experience or as part of collective, or group, memory. ${ }^{45}$ These carriers of memory are in the museum not just for the purpose of memory-transmission but also because they are meant to be seen and thus experienced as object-survivors, as first-generation witnesses to the Holocaust. Museologist Eilean Hooper-Greenhill writes in her book on museums and visual culture that "museums pride themselves on being places where 'real objects' can be seen. This notion of 'the real' is a powerful and enduring one." ${ }^{46}$ As she explains, the notion of seeing is complex here, because what is "seen" depends upon who is performing the act of seeing, the context in 
which the object is presented, and whether there is any prior relevant knowledge. In Holocaust museums, displaying artifacts that are "real" advances the museum's goal of authenticity while creating a sense of intimacy between the viewer and the past.

Artifacts are used throughout the Holocaust Memorial Museum for these purposes, and they can be grouped into two categories: artifacts that offer a sense of historical immediacy and artifacts that offer a sense of human immediacy. Artifacts such as a fishing boat that Danish citizens used to ferry Jews to safety in Sweden support the museum's narrative about righteous gentiles, non-Jewish men and women who helped save Jewish lives during the Holocaust at great risk to their own personal safety, bring the visitor close to history. An artifact such as a pair of eyeglasses or a toothbrush brings the visitor close to the human being who once used those items before meeting his or her death. In this way, and although the narrative of the museum still remains "primary," these artifacts are used "as evidence to validate and sustain the narrative." ${ }^{\text {" Th }}$ They support and uphold the story that the museum is trying to tell, and they create intimacy between the visitor, historical information, and the very human beings whom the museum memorializes.

In regard to artifacts that create a sense of human immediacy, the most striking and unusual use of this type artifacts in the museum can be found when the visitor emerges from a white and gray stairwell on the third floor of the permanent exhibition to find a dark hallway, an exhibition space lined on either side by glass walls that contain thousands of old shoes from Auschwitz that officials there agreed to loan to the museum 
during a meeting at Auschwitz on June 20, 1989. ${ }^{48}$ The hallway itself has dark gray walls, and it smells of the dark brown and black leather of the shoes. One leaves the shoe exhibition to find on one's right a rectangular, geometric collage of photographs of forearms, forearms that had each been tattooed with an identification number at Auschwitz. Opposite that, there is a wall with openings on each side, and behind the wall one finds a photograph that runs the full length of the wall — a photograph of huge, undulating piles of human hair that the Nazis had shorn from Jewish women's heads.

At the Holocaust Memorial Museum, one sees small artifacts ranging from eyeglasses to silverware to toothbrushes to photographs and large artifacts such as a boxcar and a boat. All of these artifacts fit the standard definition: they are indeed manmade, and they are all collected from a particular period of time in history: the time of the Holocaust. Museums around the world, however, collect, preserve, store, and display artifacts too: the National Museum of the American Indian in Washington, D.C. maintains an extensive collection of "approximately 266,000 catalog records (825,000 items) representing over 12,000 years of history and more than 1,200 indigenous cultures throughout the Americas.. ${ }^{49}$ The Boston Museum of Fine Arts requires fifty-three galleries to display its collection of "Art of the Americas" alone, a collection of artifacts that ranges from the Pre-Columbian era through the third quarter of the twentieth century. ${ }^{50}$ Even the Hershey Story, the museum in Hershey, Pennsylvania dedicated to the story of the Hershey chocolate company, contains over 30,000 objects drawn from three collections on the subject of company founder Milton Hershey, his factory, and the mass-production of and introduction of chocolate into American popular culture. ${ }^{51}$ It is not then the fact of using 
artifacts in and of itself that distinguishes the Holocaust Memorial Museum from a wide variety of other museums in the United States. That the museum's artifacts come from what are now lost communities or from innocent people who died persecuted also does not distinguish it from other historical and memorial museums such as the National Museum of the American Indian, which could make the same claim of the indigenous peoples whose histories and persecution it chronicles. The distinguishing factor of the Holocaust Memorial Museum's artifacts is the way that they are used to demonstrate the premeditated, industrialized nature of the Final Solution and as evidence against Holocaust denial. ${ }^{52}$ When the museum uses not one pair of shoes but thousands or not one strand of hair but a photograph of thousands, it represents synechdochically not only the sheer number of Holocaust victims but the fact that the Nazis stole shoes-and clothes, jewelry, suitcases, gold teeth, eyeglasses, and countless other personal belongings - not to mention human dignity from those they murdered or were about to murder. When the Holocaust Memorial Museum uses a boxcar or a boat in its exhibitions, the goal is not simply to demonstrate what different modes of transportation looked like at the time of the Holocaust. As cited above, the boat upholds the museum's narrative regarding righteous gentiles, and the boxcar supports, focuses, and documents the museum's narrative about the involuntary deportation of Jews and other victims of the Nazis to the concentration camps. As will be discussed in Chapter Five, however, the use of boxcars in Holocaust museums has raised questions over time about their nowsymbolic nature and the ethics of their display. 
To conclude: in the aggregate these artifacts—no matter how large or how small—serve as structural elements in the museum, for they support and illustrate the textual narrative of the museum. The artifacts also combine with the many other structural elements in the museum such as the survivor testimonies and the architectural nuances of the building, creating a powerful amalgam of sound, image, and experience that undergirds a museum experience that remains unparalleled in the United States to this day in its size and scope.

\section{C) The Holocaust Memorial Museum's Permanent Exhibition—A Tour}

Beyond these liberation scenes lies a section of the museum entitled "Before the Holocaust," immediately moving the visitor back in time from the end of the Holocaust narrative to its beginnings. The exhibition here has multiple video screens, each depicting Jewish life in a different European country before the war. The label explains that there were nine millions Jews living in Europe prior to World War II, that antiSemitism in this region had been a problem for hundreds of years, and that despite this fact, Jewish culture and traditions remained vibrant there. Immediately behind these video screens depicting happy scenes, however, is a floor-to-ceiling display of concentration camp uniforms from Auschwitz, Fuhlsbüttel, Sachsenhausen, and Stutthof. Beside this display is the entrance to a small theater showing a film ominously entitled "The Nazi Rise to Power." This film addresses topics including the accusations made against Jews that they killed Jesus Christ; myths about Jews such as the blood libel and their having horns; Martin Luther wanting Jews to convert to Christianity; and the Dreyfus Affair, making clear that there was a long history of misinformation about and stereotyping of Jews prior to the Holocaust. 
After viewing this film, one moves away from the exhibition space designed to demonstrate the quality of European Jewish life before the war and toward a long wall encased in glass and filled with photographs, artifacts, and the occasional video. The subjects covered here include "Takeover of Power, 1933," "The Terror Begins," and "Boycott." A video screen embedded in the wall plays footage from Nazi marches and rallies, and the triumphant German marching songs wash over all of the surrounding exhibitions. None of the other video screens make sound; they only show images, so it is the music of the Third Reich that accompanies every image displayed in the museum thus far. There is a distinctly ominous tone generated here, one that increases in intensity as the exhibitions unfold.

The glass wall of information continues to one's right, addressing the subject of bookburning, of Nazi propaganda, and the Nazi "Science" of Race. To one's left are materials on the Nuremberg Laws and on the relationship between technology and persecution. One learns about how Jews were excluded from society—how they moved "From Citizens to Outcasts," as the exhibit label reads. The information that the museum provides here unfolds relentlessly, mirroring the steadily mounting persecutions against Jews in Nazi Germany. The tension appears to be relieved slightly when a section on "Jewish Responses" notes that during this time, Jews reacted by becoming increasingly committed to Zionism and by attending synagogue more often. Jewish education and cultural life intensified as the persecutions increased, one is told. On the heels of this section, however, are two more exhibits: "Expansion Without War" and "No Help, No 
Haven," which explains the failed Evian Conference. By this point in the museum, one has been subsumed into the darkness of the space and met with a concise, thorough account of the events that led to deportation and concentration. Visitors have not yet been told explicitly about these two elements of Nazi practice, but there have been hints: the allusive absence of light since the moment the elevator doors shut behind them, the photographs of burned bodies and emaciated survivors that greeted visitors at the entrance to the permanent exhibition, and the strange grouping of striped uniforms.

Another theater appears at this juncture in the museum, showing a film called "AntiSemitism." At the beginning of the film, beautiful yet haunting music plays while photographs flicker across the screen: photographs of schoolchildren, of a young couple rowing a boat, of a husband and wife arm-in-arm, families, friends together on holiday, giddy teenagers. The presentation of these photographs gives way to the film's descriptions of the relationship between Judaism and Christianity. The film explains that "Christianity stems from Judaism," and it presents a succinct description of how Christianity portrayed Jews prior to the Holocaust. After watching the film, one can choose to proceed either to the right or to the left in the exhibition space. To the right one finds an exhibition entitled "Night of Broken Glass," which has two large photographs as its backdrop, each of the same synagogue in the German town of Essen - though in one photograph the synagogue is on fire. There is also an actual ark from a synagogue in the German town of Neuterhausen, with a caption that reads: "Every synagogue has an ark, a sacred place where the Torah—a scroll of the Hebrew Bible—is safeguarded." The ark in the exhibit is marred on the surface with deep scratches that have penetrated its wood, 
and the visitor learns that this defacing occurred on Kristallnacht, or the Night of Broken Glass. In the center of this section of the exhibit, there is a glass case that encloses a large pile of torn, dirty sections of Torah scroll with a label that reads: "The focal point of every synagogue is the Torah."

On the side of the room opposite the exhibit on the Night of Broken Glass, there is an exhibition called "Enemies of the State" with photographs and written descriptions of the different groups that the Nazis targeted for persecution, including Gypsies, homosexuals, Jehovahs witnesses, political opponents, and dissenting clergy. Among the artifacts displayed here are a Gypsy wagon, a Gypsy violin, and a typewriter that had belonged to Martin Niemoller, a German Protestant pastor who spoke out against Hitler. After this section, visitors move to a new section of the exhibition, "Nazi Society," and are greeted with a large glass case, at the back of which is draped a huge Nazi flag. Here the visitor can see videos and photographs from Nazi party rallies, speeches, and marches, and pictures of senior Nazi officials. An adjacent exhibition called "Police State" explains the role and development of the SS, a self-described "elite" Nazi enforcement group that controlled the police and the concentration camps.

On the opposite wall, an exhibition entitled "Search for Refuge" describes how difficult it was for Jews to escape persecution in Germany by immigrating to other countries. The exhibit explains that there was no sanctuary for Jews in the United States, that Latin America took 39, 600 immigrants, and that Switzerland and Poland were not helpful to Jews. The adjacent exhibit, "The Voyage of the St. Louis," demonstrates the plight of 
Jews trying to leave Germany on the German luxury liner the SS St. Louis. Turned away from its destination port at Havana, Cuba and from Miami, Florida, the ship was forced to return to Europe. Although several countries, including France and the Netherlands, accepted the immigrants onboard, within months the Nazis invaded these countries. One learns here that eventually many of the immigrants became victims of the war despite the fact that they had legally purchased certificates that should have allowed them permission to disembark in Havana. The museum does, however, include an exhibition entitled "To Safety: An Exodus of Culture" that states, "during the 1930s and 1940s, many of Europe's finest artists, writers, musicians, scholars, and scientists became refugees" and shows pictures of Einstein and Freud leaving Germany to take refuge in the United States and England, respectively. There is the sense that leaving occupied Europe was difficult for Jews unless they were wealthy or famous.

At this point the exhibits seem to change, leaving behind the endeavor of presenting background material and moving toward the task of demonstrating how quickly and emphatically Germany invaded and terrorized Europe. An exhibition called "Terror Against the Poles" describes the German invasion of Poland and the violence that followed. Around the corner, there are exhibits on the "Murder of the Handicapped" and the "World at War: German Conquests," as these events began at roughly the same time - the late 1930s and early 1940s. The first exhibit chronicles the German emphasis on widespread "euthanasia" of German citizens who were handicapped and/or mentally ill. The second exhibition shows how and when Germany conquered different European countries. At the end of this grim chronology of events, however, one ironically comes to 
the first place thus far in the permanent exhibition in which one is no longer in darkness: a footbridge.

One exits the white and bright footbridge and reenters the darkness. A long, dark hallway stretches ahead, and there are booths on either side in which one can listen to "American Responses" to the war and to the news being reported from Europe. On the wall are blowups of the front pages of American newspapers from New York, Baltimore, Philadelphia, and Los Angeles from wartime, all of which are reporting terrible violence and persecution overseas. This exhibition is designed to show what kind of information Americans knew about the atrocities being committed overseas, how much they knew, and when—in time for many deaths to have been prevented.

After "American Responses" comes a gray exhibition space that more closely resembles an art gallery than it does the rest of the museum. This space is filled with framed photographs by Roman Vishniac, a Russian-American photographer renown for his work depicting Jewish life in Europe before the Holocaust. Immediately following this exhibition, the visitor enters - for the first but not the last time in the museum - the "Tower of Faces," the compelling photographic exhibit described earlier in this chapter. In the next display space, one re-enters darkness, beginning a tour of the museum's third floor, entitled "Final Solution-1940-1945." To one's immediate right, there is a small exhibit space about Anne Frank that also includes information on deportations from Western European countries that Germany had occupied. To the left, one follows a long exhibition hall, titled simply "Ghettos." Here one finds information and photographs 
from countless ghettos including the ghettos in Warsaw, Lodz, Kovno to name a few. There are also large displays of ghetto artifacts and castings made from the originals: a Ringelblum milk container from the Oneg Shabbat Archive, a casting of a wall from the Warsaw ghetto, a diary, a real window from a Cracow synagogue, and a gate from the Tarnow cemetery, in which thousands of Jews were shot. A final panel explains that by the summer of 1942, there were four hundred ghettos in Europe.

The next section of the third floor explains the Nazis' use of mobile killing squads, the mass murders at Babi Yar, and the 1942 Wannsee conference at which senior Nazi officials gathered to plan and coordinate the Final Solution. In this same area, though, there is also a small exhibition on the Warsaw Ghetto Uprising of Passover 1943, making a connection to the previous exhibit on ghettos but also perhaps attempting to introduce the notion of Jewish resistance to the Nazis even as they planned to exterminate Jews at an even faster pace. That said, the exhibit moves on immediately to a section on deportations, showing dozens of pictures of Jews being deported from countries across Eastern and Western Europe. A German boxcar standing on train tracks that led to Treblinka anchors this exhibition space; one can even walk inside the boxcar, emerging into another large exhibition space, "Who Shall Live and Who Shall Die." In "Who Shall Live and Who Shall Die," one sees dozens of photographs of Jews climbing out of boxcars onto train station platforms, waiting on the platforms, and being put into lines. An equally large panel shows hundreds of small individual pictures of prisoners from concentration camps, along with the colored triangular badges that indicated whether the prisoners were Soviets, Romas, Homosexuals, political prisoners, 
or Jehovah's Witnesses. On the opposite wall, one finds a glass exhibition case filled with shelves containing victims' belongings and information about how the Nazis took victims' belongings: leg braces and artificial limbs, tooth-, hair-, and shoe brushes, and Jewish prayer shawls. Another similar case contains more objects: piles of scissors, kitchen utensils, eyeglasses, thermoses, bowls, cups, and cutlery. One looks closely at these deeply personal item, then moves forward in the exhibit, passing under a casting of the original sign over the gates of Auschwitz, which reads "Arbeit Macht Frei" or "Work Makes One Free." Here one enters the section of the museum that offers explicit information about the concentration camps. To one's left is the audio exhibition mentioned earlier in this chapter, the space in which one can hear Auschwitz survivors' testimonies.

One emerges from this intimate experience with the survivor testimonies to find room after room of information about slave labor in the camps, the killing centers, medical experimentation in the camps, and artifacts from the camps. There are bunkbeds from Auschwitz, videos about the medical experiments so terrible that they are hidden behind five-foot walls, and an eerie white diorama that depicts victims lining up, being gassed, being exterminated, and being cremated. Moving forward one finds large artifacts on one's left: a medical experimentation table from Majdanek and a crematorium from Mauthausen. The wall on the opposite side of the hallway is lined with castings of fence posts from Auschwitz, behind which is imprinted a quotation from Holocaust survivor Elie Wiesel's Night that begins, "Never shall I forget that night, the first night in camp...." After reading these words, one sees a familiar sight just ahead: the Tower of 
Faces, and beyond that, the stairwell that leads to the small lobby filled with the Sol LeWitt paintings mentioned earlier.

The last floor of the museum's permanent exhibitions, "Last Chapter," begins with a narrative of the German retreat from allied forces: "World at War: The German Collapse." Here the museum devotes significant attention to righteous gentiles on a long panel, "The Courage to Rescue." One learns about the village of Le Chambon, American rescue efforts, Raoul Wallenberg, and the Polish resistance group Zegota. There is even a boat that accompanies a description of how the Danish used boats to save Jews and get them to safety. A long, glossy white panel that runs between these two exhibitions is inscribed with the names of hundreds of the righteous. There are descriptions of how Palestinian Jews tried to help, the White Rose, resistance in the camps, ghetto revolts, death camp revolts, and Jewish partisan groups. Juxtaposed to these images and powerful descriptions of resistance are pictures from the liberation of the camps and of the death marches. Films from the liberation are hidden again behind high walls, their contents deemed too graphic to be displayed with proper respect. There is again a group of camp uniforms, just as one saw at the very beginning of one's tour, which began with a photograph taken at the time of liberation. The tour has come full circle, only this time one has learned what preceded the liberation photo that began one's experience in the museum, and at this point one learns about what the museum calls the "Aftermath." One is only now told in greater detail about the fate of children during the Holocaust: in hiding, in ghettos and camps, and after liberation. One sees their artwork and looks at their pictures. Again juxtaposition occurs: on the wall opposite the children's wall is an 
exhibition that asks who the perpetrators were - who were the Nazis, and who were the people who committed such atrocities, against even innocent children? Another section examines the problem of the bystander: who were the people who never helped those in need, who never spoke out against what they knew was happening in their communities?

The final section of the permanent exhibition addresses four major issues from the postwar era: that there were still pogroms and anti-semitism after the war, that there were thousands of displaced persons - many of whom wanted to go to Palestine; that Jews did eventually start over with new jobs, lives, and families; and that Europe will forever remain a Jewish graveyard. This latter point is underscored on a wall of dozens of castings made from Jewish gravestones that are placed on the last bit of wall space in final illustration of the terrible finality and irreversibility of the Holocaust. Opposite this wall is the Jerusalem-stone amphitheater in which Gerda Weissman-Klein's testimony is shown on an enormous projection screen.

After hearing Klein's testimony, one finds the museum's Hall of Remembrance. The lobby outside of the Hall of Remembrance is lined with flags, pictures, and information about Jews who resisted during the war, people such as Mordechai Anielewicz, Tuvia Bielski, Abba Kovner, and Hannah Senesh. One can see from this spot that there is a small gift shop ahead, a sign for an exhibit called "From Memory to Action," which will also be described in great detail in Chapter Four, and a stairway to the entrance lobby of the museum, the Hall of Witness - where hours before one had first entered the museum. 


\section{The Los Angeles Museum of the Holocaust}

Like the Holocaust Memorial Museum, the Los Angeles museum is located in an urban setting, but the two urban settings are quite different from one another. The Holocaust Memorial museum, as mentioned earlier in this chapter, blends in with the other buildings several blocks in both directions, most of which are large, imposing, gray government buildings. The street onto which its front entrance faces is wide and busy, but the wide expanses of homogenous buildings imbue the area with a rather desolate air. To the contrary, the Los Angeles museum's entrance is on a small side street—but it is near a major intersection that is surrounded by colorful shops, office buildings, restaurants, parking garages, and people. The hustle and bustle of the crowds and the cars, the palm trees, and the almost invariably beautiful weather create a bright, lively environment much unlike the gray, uniform façade of the street on which the Holocaust Memorial Museum is located.

Also unlike the Holocaust Memorial Museum, the idea for the Los Angeles Museum of the Holocaust emerged through a group of local survivors, not through national, political, and governmental channels. When a few Holocaust survivors taking an English-language class at Hollywood High School in Los Angeles, California met in the early 1960s and realized that each of them had preserved artifacts, photographs, and/or documents from their experiences in the Holocaust, they came up with the idea for creating a museum. In the interest of conserving and displaying these artifacts and with the goal of preserving the memory of the Holocaust, they joined together to found a one-room exhibition that opened to the public in 1978 as the Los Angeles Martyrs Museum in the Jewish 
Federation Building on Wilshire Boulevard, a major thoroughfare in Los Angeles that runs east-west from downtown Los Angeles to the Pacific Ocean. In 1991, the museum — by then called the Los Angeles Museum of the Holocaust—moved to a larger space next door in the interest of expanding, but "multiple setbacks ensued in the years that followed... and in 2004 it had to close altogether when the building in which it was housed was sold to a developer." ${ }^{53}$ The museum's Acting Executive Director, E. Randol Schoenberg, explained that the need for a building that was appropriately retrofitted to guard against earthquake damage, a lack of funding from the Jewish Federation of Greater Los Angeles, and the presence of higher-profile museums such as the Holocaust Memorial Museum and the Museum of Tolerance made it more difficult for the small museum to succeed during this time. ${ }^{54}$ Museum staff and museum supporters maintained their connections to the museum, however, and eventually they raised money to rebuild and relocate the museum to its current home in Pan Pacific Park, where it opened in October 2010. The museum's mission is "Commemoration and Education" ${ }^{\mathrm{N} 5}$ as it has been since its inception.

In some ways, Pan Pacific Park is a logical location for a Holocaust museum, for it is near what is known in Los Angeles as "the Fairfax district," a street called Fairfax Avenue that is heavily populated by an observant Jewish community. Intuitively, it is logical that the museum would be located in a Jewish neighborhood, especially as the two other Jewishly-affiliated museums in Los Angeles, the Museum of Tolerance and the Skirball Cultural Center, are also located in other predominantly Jewish areas of the city. The proximity of the Fairfax district to the Los Angeles Museum of the Holocaust means 
that within a few-mile radius of the museum, there are a synagogue, an Israeli bakery, a Jewish food pantry, the Bet Tzedek Legal Services office, a Jewish Family Services office, a kosher market, and Los Angeles's most famous “Jewish” deli, Canter's. Pan Pacific Park also has two Jewish memorials, the first being dedicated to the Munich Olympic Victims. For this memorial, "a copse of 11 trees and a plaque on a quiet hill honors the memory of the 11 Israeli athletes taken hostage at the 1972 Munich Olympics and then killed during an attempted rescue. ${ }^{56}$, The second memorial, which is discussed in more detail below and is also a Jewish memorial, is incorporated into the exterior design of the museum and is visible from one of the park's many large green spaces.

In an interesting juxtaposition to the nearby Jewish neighborhood, the memorials, and the urban respite of the park, the museum is located directly across the street from an outdoor mall called The Grove, which describes itself as "the place to shop... where LA comes together. ${ }^{, 57}$ This shopping mecca is especially well-known for its faux snowstorms at Christmastime, its "dancing fountain," its high-end retail stores, and its immediate proximity to Los Angeles's exceptional The Original Farmer's Market, which features culinary offerings from around the world. Needless to say, amidst the activity of the area, it is easy not to notice the museum from the street even though there is a medium-sized sign indicating its presence, and without prior knowledge of the active local Jewish community, one might never assume that a Holocaust museum would be located here. Meanwhile, from the street only the sign indicates that there is a museum nearby at all. The entrance to the museum's tiny underground parking garage is nondescript, and the 
museum itself is almost completely hidden from view: it is underground. In this way, it is vastly different from almost all Holocaust museums in the world.

\section{A) Exterior Elements}

The museum's roof is entirely covered by grass that blends in perfectly with the green lawn of the surrounding park, though the roof does stand out from the landscape if seen aerially, for architect Hagy Belzberg designed concrete, sculptural lines that crisscross the grass-covered roof of the museum. The glass front entrance to the museum is embedded into the hillside under which the museum is built, and a white concrete façade surrounds it. The façade is engraved with 1.2 million tiny holes in memory of the 1.2 million children who died during the Holocaust. Also engraved there are the names of donors to the museum and the names of those who perished during the Holocaust. A small memorial plaza next to the entrance looks out over the quiet and verdant setting of the park and is home to a series of six large, black memorial obelisks. The obelisks constitute the Los Angeles Holocaust Memorial/Martyr's Monument, the second memorial in the park, which was built thanks to the fundraising efforts of an organization called the American Congress of Jews from Poland and Survivors of Concentration Camps. ${ }^{58}$ From this angle, facing the obelisks and the front entrance, the museum's exterior is startling: the vertical black obelisks contrast with the white horizontal shapes of the plaza, entrance, and façade of the museum — all of which appear cut into the bright green hillside like giant shards of concrete that have stabbed the lawn and then embedded themselves into the wounds there. The effect is disconcerting, and it is meant to be so. The intention is that the museum's exterior should create a sharp distinction between the 
merriment of the surrounding park and the tragic story that unfolds within its subterranean walls, and it does. Even if one did not know that the structure contained a Holocaust museum, the lines of the building and its setting deep in the hillside would be surprising, puzzling, and disconcerting. In this museum, one is meant to feel disconcerted.

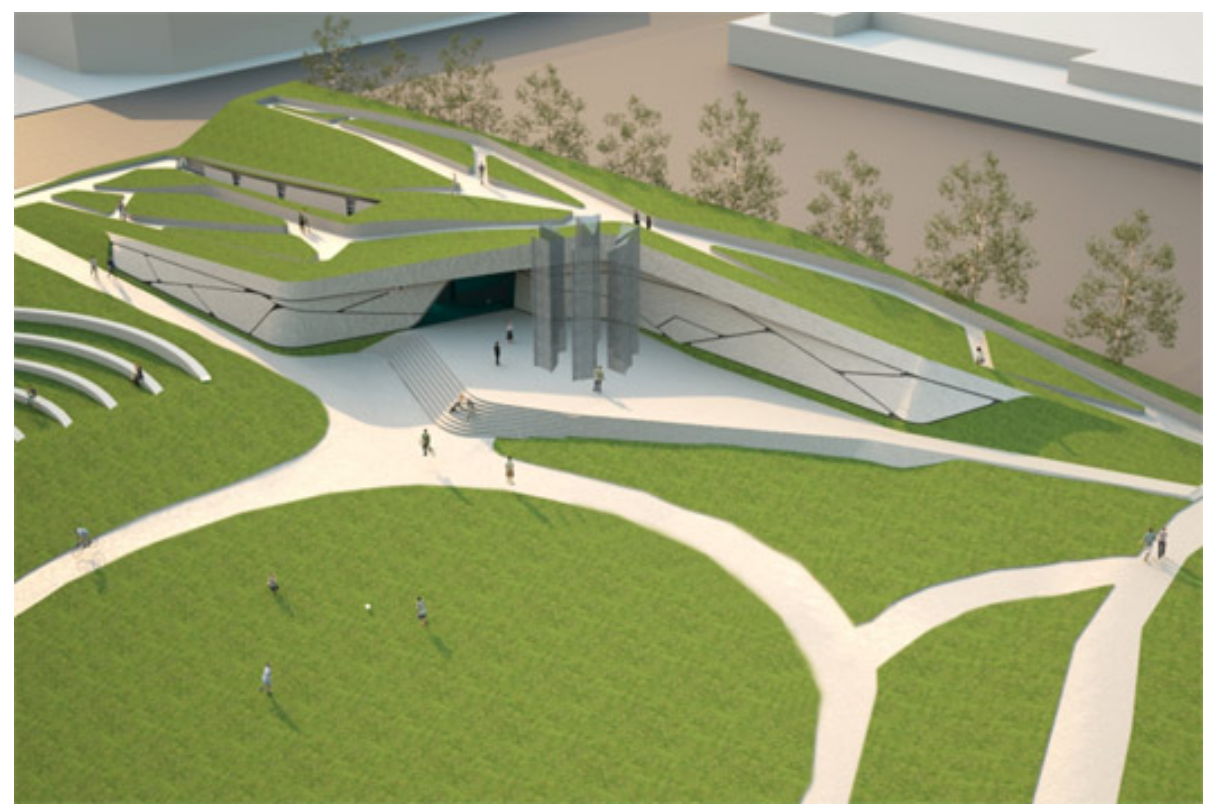

Los Angeles Museum of the Holocaust. http://2.bp.blogspot.com/ NjUov1-

0KnU/TMuTibofL0I/AAAAAAAAMUw/zcQEkXVrJRI/s1600/8a.jpg. Accessed September 16, 2013.

\section{B) Interior Elements}

\section{i. Entrance Lobby and Floor Plan}

The interior of the museum is just as unique as its exterior. In the entrance lobby or atrium (and throughout the museum), the museum's modern architecture is again immediately noticeable and compelling. Its use of a shiny concrete on the floors and white modernist walls create beautiful angles; sloping, almost cave-like ceilings and walls; and stark color contrasts throughout the museum - especially in comparison to the bright, flawless, quintessentially Southern Californian weather outside and the green expanse of the park. The starkness of the architecture complements the starkness of the 
exhibitions as well, which are comprised mostly of backlit black-and-white photographs with artifacts on display in a few of the rooms. There is little color in the museum, which creates the feeling of walking through the past, of being the one person alive amidst a landscape of destruction, and of being far away from the busy, bright world from which one has just departed.

In the doorway of the museum, one finds a mezuzah on the doorpost, the first of many in the museum, where mezzuzot mark every doorpost in the building including staff offices - regardless of whether the staff member is Jewish. The use of the mezuzah is a surprising move for a Holocaust museum and is therefore especially notable. Although Holocaust museums educate visitors about a period of history that affected Jews specifically, it is rare to find a Holocaust museum that incorporates elements from Jewish religious material culture in this way. Holocaust museums typically distance themselves from educating visitors about Judaism; that task is left instead to Jewish museums, which in turn do not usually do more than include a small exhibition space or brief acknowledgement of the Holocaust. That said, for a non-Jewish visitor, the mezuzah might merely be seen as an objet d'art if its religious significance is not understood.

Just inside the doorway where the mezuzah is located, one finds an entrance lobby and information desk, a security guard, and a large video monitor. After checking in at the desk and receiving the museum's audio guide, visitors are directed to watch an introductory video on the lobby monitor by using the audio guide. After watching the video in the Atrium, one begins to proceed through the museum, the floor plan for which 
is in the shape of an inverted $\mathrm{U}$. One begins on the right-hand top side of the $\mathrm{U}$, with the floors sloping downward slowly and the lighting growing dimmer the further one moves into the museum. The intention here is that the gradual downward slope of the museum and the gradual descent into darkness echo the gradual loss of Jews' rights, freedom, and identity at the time of the Holocaust, with the lowest point of the museum being its exhibition on the camps, the darkest, deepest, most isolated part of the war and in the museum.

\section{ii. Technological Innovations-The iPod Touch Audio-Guide:}

One of the Los Angeles museum's most noticeable features is not, like the Holocaust Memorial Museum, architectural or aesthetic but technological. When one enters the museum and checks in at the desk in the atrium, one is given an iPod Touch and earphones to use as an Audio Guide to the museum, which works as follows: In each exhibition space, most artifacts, video screens, and pictures are tagged with a number and sometimes with a brief title — but no explanatory label as is customary in museums of all kinds. One locates the appropriate number on the iPod Touch, taps it, and listens to the information recorded there. While museums of all kinds have used audio-guides for decades, it is unusual to find a museum that is fully-equipped with the most recent technology and makes that technology available to all visitors at no cost. The Los Angeles museum is so new that it has had the opportunity to implement cutting-edge technology easily and without having to overhaul preexisting information delivery systems. Schoenberg explained that the intention behind the technology was to make the museum "encyclopedic," 59 both in the interest of establishing the museum as a resource 
for information and evoking the enormity of the Holocaust through providing copious amounts of information in easily accessible ways. It is also unusual to find a museum that relies so heavily on its audio-guides, so their use at the Los Angeles museum and the lack of labels signifies a departure from museological norms and adds another layer of distinctiveness to an already distinctive museum, with a key element of this distinctiveness being that the audioguide includes music where appropriate. ${ }^{60}$

Before one enters the museum's permanent exhibition, one stands near the front desk and uses the iPod Touch for the first time: to watch a video playing on a screen that is embedded in the wall. The video features Jack Taylor, a native of Los Angeles who was a soldier in the U.S. Army and participated in the liberation of a concentration camp. Like the Holocaust Memorial Museum, the Los Angeles museum chooses to begin its narrative of the Holocaust with the end of the story, with the liberation and with testimony from a liberator. The museum's intention here is not only to hint at the atrocities that are to be revealed in the permanent exhibition but also to link the history of the Holocaust to the history of Los Angeles. Like many Holocaust museums, the museum attempts to create a relationship between its home city and the people and events of the Holocaust.

\section{iii. Technological Innovations--The Memory Pool Table}

The World That Was, the first section of the museum's permanent exhibition, includes what the museum calls an "Interactive Memory Pool Table." The Los Angeles museum's memory pool table is meant to be a "virtual photo album featuring photos from the 
Museum's collection and the wealth of material in [its] data base." ${ }^{\prime 1}$ It resembles a giant black iPhone and employs similar touch-screen technology. If one touches one of the photographs that appears on the table's surface, then immediately information about the person in the picture appears. The table is equipped with a "docent mode" that allows museum docents to gather students around the table and have each student seeing the same picture and the same information simultaneously, as chosen by the docent for specific educational purposes. The Holocaust Memorial Museum includes a similar table in one of its semi-permanent exhibitions, but it is used only for information delivery, not interactive lessons. The goal here is for visitors to have access to the museum's collections and database in a way that would be nearly impossible without high technology and for visitors to conduct searches of the collections and data base according to their individual interests - as opposed to being able to learn only what is written on the wall of the museum.

\section{iv. Technological Innovations-Concentration Camp Computer Monitors:}

In the section of the museum entitled "Deportation \& Extermination" there are again many photographs, but there are also eighteen "Interactive Concentration Camp Monitors," which are organized such that each of eighteen different concentration camps is assigned a flatscreen computer monitor that stands apart from each of the others at about waist height. Each monitor then has multiple types of information about that camp, including live footage taken at the camps, camp statistics, information about the perpetrators, and brief video clips from survivors of those camps discussing their experiences there. This exhibition is so clearly organized that it is immediately obvious 
what the visitor is expected to do: walk up to any monitor and start to touch its screen while still listening to the audio through one's iPod Touch and headphones. The amount of information available about the camps is seemingly endless, and the survivor testimonies in each monitor are carefully chosen to discuss only that particular campthe terror of the camps feels endless too.

\section{v. Survivor Testimony}

At the Los Angeles museum, all survivor testimonies or clips of testimonies are accessible only through the audio guides with one exception: live survivor testimonies that are available several times per week and on special request. To access the testimonies that are integrated into the permanent exhibition, one must stand in front of a particular picture, artifact, or video screen, press the corresponding number on the audio guide, and stand in front of the exhibit to hear the testimony. One could take the device back to the lobby and replay the selected bit while seated on the benches in the lobby outside the museum's restrooms, but the visitor's inclination and the pedagogical intention are for the visitor to be looking at the object, photograph, or video while the testimony or descriptive audio information is being provided.

\section{vi. The Tree of Testimony}

At the end of the museum's permanent exhibition, there remains one more unusual, again unprecedented exhibit to see, one that consists entirely of survivor testimony. In April 2012 the museum added a "video sculpture," the "Tree of Testimony," to a previously empty space in the museum. The sculpture is not made of stone but of seventy flatscreen 
televisions laid onto steel supports and designed to look like a many-branched tree. Each screen shows the testimony of a different Holocaust survivor; there are 52,000 in the collection, which belongs to the University of Southern California Shoah Foundation. They are rotated throughout the year so that each testimony appears at least once. One finds the audio to the testimonies on one's audio guide and can choose accordingly which testimony one wants to hear. The museum asserts that its intention here is to ensure that survivors' voices are always heard and that each survivor's individual story has a chance to be told in his or her own words. Schonberg wanted an "egalitarian, democratic, unedited" use of testimony in the museum that would "show off the LA phenomenon of the Shoah Foundation" and "represent the enormity of the tragedy." He also wanted to ensure that every single survivor testimony in the Shoah Foundation's cache could be viewed in the museum, noting that "more than fifty percent of the testimonies had never seen the light of day." It would take, he explained, sixty years to listen to all of the testimonies played in the Tree of Testimony. ${ }^{62}$ 


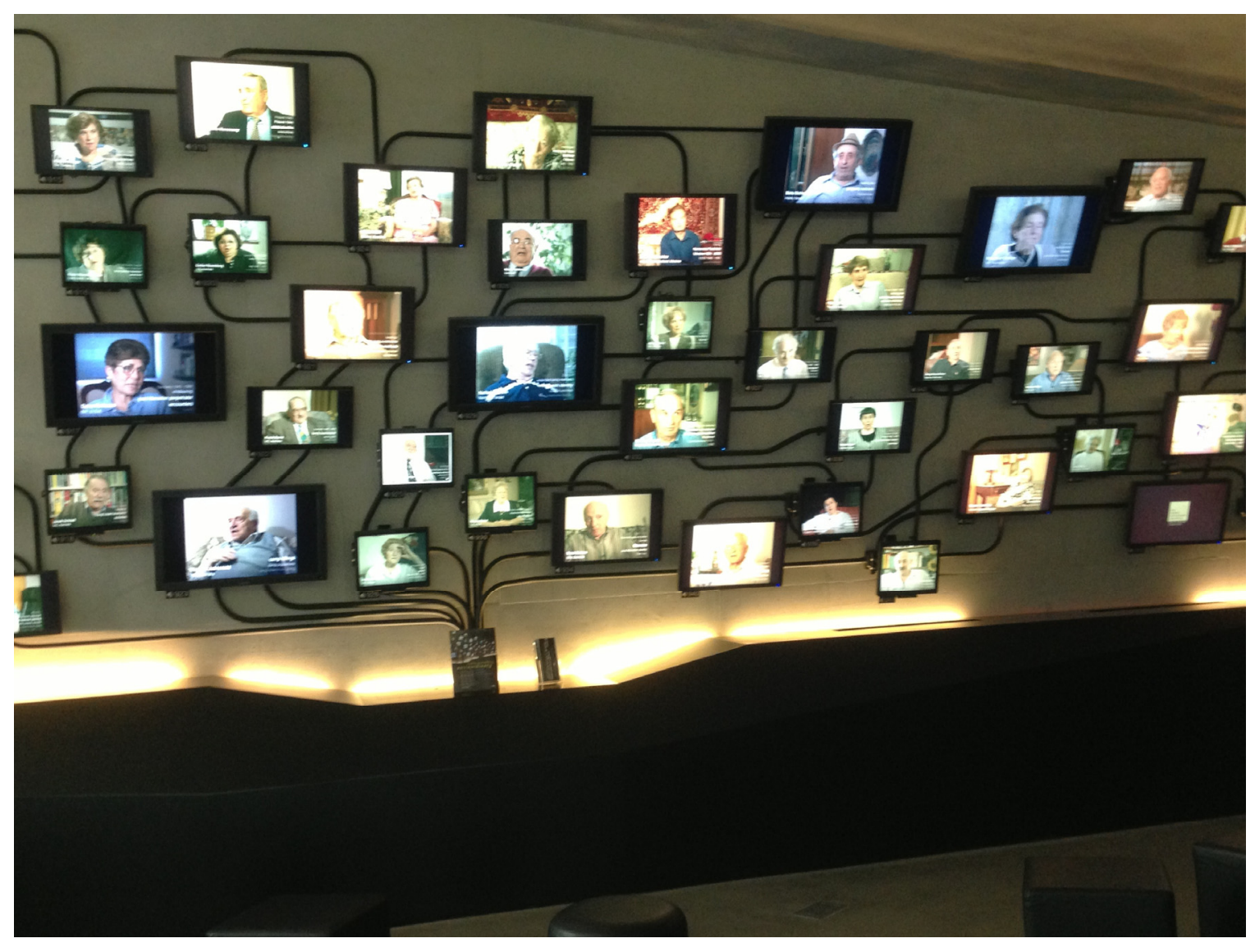

Sievers, Leah Angell. Los Angeles Museum of the Holocaust. December 2012.

\section{vii. Artifacts}

The most noticeable feature of the museum's first exhibition space, The World That Was, is its collection of artifacts. In this section of the museum, one can see not only photographs of pre-war Jewish life but also objects such as shofars, candlesticks, a menorah, a Torah scroll, prayer books, dolls, a tea set, and even a baby's jacket that Jewish families used at the time. Other artifacts found throughout the museum include suitcases, anti-Semitic materials designed for German children, shoes, concentration camp uniforms, star of David badges, Jewish identification cards, coins, a leather briefcase, and a baby grand piano. The exhibition space known as "Life After Liberation" contains the piano, the "Bluethner piano," so-called for the German family 
that crafted it. When the survivor who owned the piano before the war, the musician Alfred Sendry, immigrated to Los Angeles after the war, the Bluethner family shipped it to him there so that he could be reunited with his instrument. ${ }^{63}$ The piano's presence seems almost ironic given its context—a Holocaust museum — and its location at the end of a tragic narrative, but that irony and the beauty, grace, and majesty of the instrument combine to underscore a theme that the museum's internal and exterior architecture sets from the very beginning: that the Holocaust was a radical, disorienting, and utterly disconcerting departure from the norm.

\section{C) The Los Angeles Holocaust Museum-A Tour of the Permanent Exhibition:}

At the beginning of one's journey through the museum, however, there are four exhibition spaces on the right side of the U: The World That Was, Rise of Nazism, Onset of War/ Ghettoization/ Extermination, and Deportation \& Extermination. The goal of the World That Was is to educate the visitor about what European Jewish life entailed before the war and about how Jews in those geographical areas contributed to society in invaluable and innumerable ways. In addition to using relevant photographs and information on the audio guide to achieve this end, The World That Was also relies on Jewish religious objects from the Holocaust era such as copies of the Talmud, a Torah scroll, Kiddush cups, and a Purim grogger to elucidate this aspect of life before the war.

In the next section of the museum, Rise of Nazism, the topics covered include information about Adolf Hitler, anti-Jewish legislation, examples of Nazi propaganda, the Nuremberg Laws, boycotts, bookburning, discrimination against Jehovah's Witnesses, 
and the SS St. Louis. There are photographs of Hitler, Nazi flags, German citizens performing the Heil Hitler salute, and German soldiers - to name a few-and two exhibit cases containing artifacts such as suitcases, books, and photographs. On the walls of the hallways outside the exhibit are copies of the front page of the Los Angeles Times from various dates throughout the war, designed to demonstrate the degree to which Americans knew of persecutions being committed in Europe against Jews. The information presented here accurately demonstrates the degree to which the Nazis discriminated against Jews and others and the degree to which the United States was unwilling to help those being persecuted find refuge in the United States.

After Rise of Nazism, one proceeds to Onset of War/ Ghettoization/ Extermination. This exhibition includes picture after picture of places such as Warsaw, Lublin, Teresienstadt, Vilna, and Lodz, and it covers topics such as the Nazi invasion of Poland, the Einsatzgruppen, Babi Yar, Pearl Harbor, and the Japanese internment camps in the United States. The pictures' borders touch each other, creating a patchwork quilt of images that range from difficult to horrifying. Equally horrifying is the information presented here regarding the Nazis' practice of exterminating the handicapped and mentally ill through its state-sponsored euthanasia program, "T4." At the very end of the exhibition room, there is a partial model of a boxcar through which one can walk in order to reach the next section, Deportation \& Extermination, as described earlier in this chapter. 
This exhibition room merges with the next exhibition room, Labor/ Concentration/ Death Camps, at the bottom of the U-shaped floor plan; there are two camp uniforms on display here as well as a model of Sobibor Death Camp. Here one can listen to a Sobibor survivor's testimony about the camp and about the famous prisoners' uprising staged there. On a wall opposite the display of the camp uniforms, there is a panel on which are printed Rafael Lemkin's definition of genocide and one picture each representing four genocides - those in Armenia, Rwanda, Cambodia, and Darfur. The audio guide offers a brief amount of information about each genocide and repeats Lemkin's definition.

After this descent into the horrors of the concentration camp and the reminder that there have been genocides both before and after the Holocaust, one begins to proceed through the final rooms of the museum-World Response, Resistance, Rescue, Life After Liberation, a room for survivor testimonies and temporary exhibitions, and Tree of Testimony - finally walking upward again after the previously grim descent and into increasingly well-lit spaces. The final two exhibition rooms-World Response, Resistance, Rescue and Life After Liberation - tell their stories in much the same way as the other rooms in the museum: through photographs, artifacts, and the audio guide. The former room—-World Response, Resistance, Rescue—is careful to tell the stories of diplomats who helped Jews escape, of students who protested the Nazis, and of Jewish resistance such as the Warsaw Ghetto Uprising, but the exhibit makes it clear that the stories of righteous gentiles are few and far between and that most people and most countries at the time did little or nothing to help those the Nazis were persecuting. Life After Liberation demonstrates the challenges that Jews faced after the war as well as 
explaining where they settled: Israel, Canada, Australia, parts of Europe, and the United States, and it contains the previously mentioned "Bluethner piano." The Tree of Testimony, which will be further discussed in Chapter Four, serves as the final stop in one's tour of the permanent exhibition. The visit thus ends with the voices of the survivors ringing in one's ears and a bright shaft of light from the park beckoning one to the lobby.

\section{The Illinois Holocaust Museum \& Education Center}

Another recently built Holocaust museum, which opened on April 19, 2009 one year before the new Los Angeles museum, is the Illinois Holocaust Museum \& Education Center in Skokie, Illinois. Skokie is a predominantly Jewish suburb north of Chicago where between seven and eight thousand Holocaust survivors gradually settled after the war, many leaving downtown Chicago for Skokie for more space and more affordable housing. The Illinois museum's first iteration came about under unique circumstances: In 1976 Frank Collin, the leader of the National Socialist Party of America, a group of Nazi sympathizers, requested that his party be permitted to hold a march in Skokie. The request prompted two years of debate and legislation that found unconstitutional the Village of Skokie's rejecting the group's request to march. Although Collin eventually called off the march, the prospect of the march had prompted outrage amongst Jews and survivors around the world. Skokie-area Holocaust survivors responded with indignation, breaking a relative silence — at least to the public — about their experiences during the war and founding the Holocaust Memorial Foundation of Illinois, the first iteration of what later became a small museum and is today the Illinois Holocaust 
Museum and Education Center. As the museum's executive director Richard S. Hirschhaut explains, "It's not going too far to say that [what happened in] Skokie really catalyzed the way we learn about the Holocaust today and the way we apply lessons of the Holocaust to understanding and learning about contemporary genocide...In the late '70s, Skokie put the whole subject on the map." ${ }^{, 64}$ Here Hirschhaut alludes to the development of Holocaust museums when he states that the events in Skokie served as a catalyst for Holocaust education, for at the time of the controversy, there were no major Holocaust museums in the United States. The idea of learning about the Holocaust through a museum existed —at Yad Vashem and in small collections in cities like Los Angeles and Detroit—-but not in a widespread way as we know to be true today.

Lillian Polus Gerstner, the daughter of two Holocaust survivors, began to volunteer at the first iteration of the museum in 1985, and in 1991 she joined its paid staff as Executive Director. When the state of Illinois mandated Holocaust education in 1990, the museum saw a much greater demand for its services. It ran Holocaust education classes two nights per week, led training sessions, and hosted survivor speakers among other offerings; Gerstner and her small staff could barely keep up. As she explained, the 5,000square-foot facility "could not sustain the need of the community or what would be needed when survivors couldn't be there." ${ }^{, 65}$ Out of these growing concerns, local survivors spoke to J. B. Pritzker, a Chicago-area venture capitalist who is also the President of the Pritzker Family Foundation, about building a new Holocaust museum. Pritzker told them, "raise a million dollars, and then we'll talk." promptly raised one million dollars from a single donor, and Pritzker became committed 
to the idea of the new museum both philanthropically and personally, eventually becoming its Chairman.

Since 1981, the organization has educated school and community groups through its speakers' bureau and museums. The 65,000-foot new facility-stark, white, and modern in appearance-became necessary if the museum were to accommodate far more visitors, especially school children, in the interest of further advancing the Illinois Museum's goal of educating the greater Chicago area about the Holocaust. The museum hired worldrenown architect Stanley Tigerman to create a three-part structure that would accommodate space not only for exhibitions but also for classrooms, a library, a meeting hall, a lunchroom, a hall for personal reflection, and an auditorium — and create a unique architectural statement.

\section{A) Exterior Elements}

One approaches the Illinois museum by turning onto Woods Drive, a quiet street off of Golf Road, a busy thoroughfare that bisects the even busier Skokie Boulevard. One cannot see the museum from either the Boulevard or Golf Road; the only hint of it is a semicircle of concrete embedded in a grassy hillside on which is printed only the words "Remember the Past, Transform the Future." The museum itself is difficult to identify when it finally comes into view on Woods Drive, for it is approached from behind, not from the front, so that it can face east toward Jerusalem. Its large, gray, back wall looks industrial and nondescript. If it did not have its name printed in large letters on the side of the building, one might not notice it at all or mistake it for a warehouse. After driving 
around the back and right sides of the museum one arrives at the front entrance, which is small and painted entirely in black. The black roof over the entry doors has the name of the museum on it in silver block letters, but the entrance looks more like a back door or service entrance.

Oddly, one can only see the entire front of the museum at once by standing at the back of one of the museum's parking lots. It is only from this perspective that one can take in the enormity of the building. The three-story museum resembles two slightly angled steel and concrete buildings connected together at the center by what Tigerman's firm calls "an ineffable and inaccessible space, ${ }^{, 67}$ a lower structure that joins the two. The building on the left is black, the building on the right is white, and the juncture between the two is also white - all color choices that are meant to be symbolic first of evil and despair and then, with the white, of hope. "White is about hope," explains Tigerman, "[In the camps] they made art, they played in orchestras...if you're alive, there's always hope." ${ }^{68}$ The black building features sharp angles, triangular rooftops, and a complete lack of windows, while the white building features rounded rooftops with white sunburst patterns on their vertical, glass surfaces. The juncture or hinge that joins these two distinct spaces uses both angular and rounded lines and is much smaller than either of the two buildings. Two empty columns frame it on either side, creating an unfinished, disconcerting effect. Tigerman designed the columns so that their dimensions would match exactly those of Solomon's Temple in Kings 5-9, and he measured those dimensions in cubits, an ancient form of measurement. ${ }^{69}$ This effort is part of Tigerman's plan to weave subtle Jewish influences into the structure of the museum even though he has not previously designed 
any Jewish buildings such as other museums, a Jewish community center, or a synagogue.

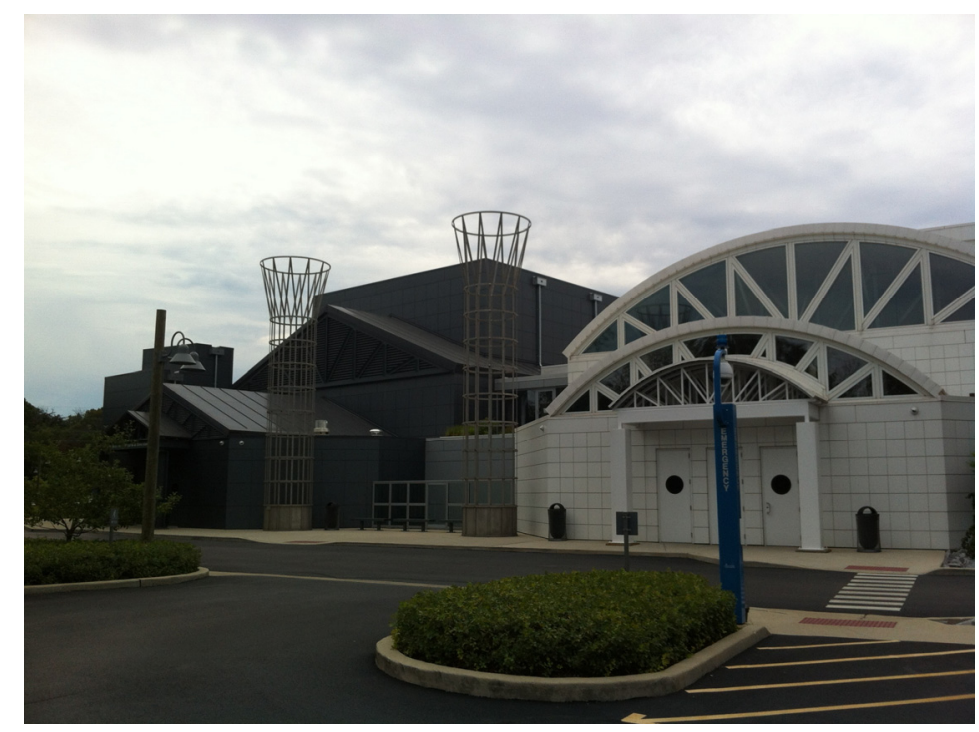

Sievers, Leah Angell. Illinois Holocaust Museum \& Education Center. July 2012.

\section{B) Interior Elements}

\section{i. The Entrance Lobby}

The preliminary entrance lobby to the museum is small and dimly lit, brightened only by friendly volunteers anxious to welcome visitors and by the equally friendly and courteous security staff who monitor the entrance, the metal detector, and the x-ray machine through which all of one's personal items must pass prior to admittance. After passing through security, one arrives in another slightly larger but equally dark lobby. There are an information desk straight ahead and a small glass entrance to the museum's Zev and Shifra Karkomi Permanent Exhibition to the left. To the right, one can see a hallway to the elevator and to what seems to be another, distinctly brighter part of the museum. This lobby is more akin to the Los Angeles museum's lobby, with its mix of dark and light 
colors, but it is not as architecturally distinctive. It is also vastly different from the Holocaust Memorial Museum's vast, bright Hall of Witness with its characteristic brick, steel beams, and distant footbridge.

\section{ii. Legacy of Absence Gallery, the Room of Remembrance, and the Pritzker Hall of Reflection}

In the brighter section of the museum that one can glimpse from the lobby, there is a lobby outside of the exit from the permanent exhibition and a large gift shop. A white, curved stairwell leads upstairs to the Legacy of Absence Gallery, the Room of Remembrance, and the Pritzker Hall of Reflection. The Legacy of Absence Gallery, which is described in greater detail in Chapter Four, is a gallery that exhibits the work of contemporary artists' responses to genocide. The Room of Remembrance is a semicircular space lined from floor to ceiling in warmly-colored, yellowish woods and stone. It is lined with benches where one can sit in contemplation and remembrance of those who lost their lives during the Holocaust. Its curved walls soar to the ceiling and are engraved in black Hebrew and English writing with the names of victims. The space is cozy, comforting, and beautiful, unlike the brutalist aesthetic of the rest of the museum. Two stone pillars stand on either side of the room's centerpiece, a large book enclosed in glass that is open to a page covered in names - the names of the victims. The Pritzker Hall of Reflection is also meant as a space for quiet reflection. Unlike the Room of Remembrance, its materials and color scheme reflect that of the rest of the museum: a spare, modern style with a white, exposed-beam ceiling, black tile floors and cubes (of which there are twelve, to represent the twelve tribes of Israel), and gray stone walls. 
Eighteen square windows punctuate the curved, gray back wall of the room at equal intervals, with each window containing a single votive candle. Museum publications describe the candles as memorial candles meant to be "symbolic of life" that "add

illumination and a message of hope to this hallowed space [the Hall of Reflection], ${ }^{, 70}$ though to this observer, it is a cold and sterile space that feels more empty than hallowed.

\section{iii. The Babi Yar Exhibit}

After leaving the museum's exhibit on Ghettoization, the visitor enters a small room containing information and pictures about the Einsatzgruppen, mobile killing squads that comprised Hitler's first attempt at mass murder, and about the massacre at Babi Yar, where the Einsatzgruppen murdered over 33,000 Jews over the course of two days in September 1941 by shooting them in small groups into a ravine outside of Kiev. The now-iconic photograph of a Nazi soldier taking aim at the back of a woman holding a small child to her chest hangs prominently on the wall, encapsulating the historical information in one terrifying image. Around the corner, one finds a dark, tunnel-shaped exhibit lit only by the flickering light of a television screen. The walls are wallpapered in a black and white pattern that is difficult to discern, especially given that the carpetwhich suddenly changes from the hard institutional carpet used throughout the permanent exhibition to a soft, thick weave-is made in the same pattern. After a moment, though, one begins to understand.

The film shows footage of soldiers shooting people at the edge of what looks like a giant pit or ditch; their bodies crumple and fall into the pit, and the soldiers cover them with 
dirt. The wallpaper and carpet of the exhibition space are made to resemble the mottled color of the soil inside of the pit in the film, so when one watches the film, one has the sensation of watching the murders from within the ravine, only a few yards away from where they are actually taking place. The effect is disorienting and creates an admixture of sensations of victimhood, voyeurism, and guilt. It is from this place of uncertainty and from this feeling of having nearly "witnessed" Babi Yar that one emerges into the museum's exhibit on the Final Solution, where one learns about the Wannsee Conference and about the Nazi plan devised there to exterminate the Jewish people. There is now the distinct and unalterable sense that a certain endpoint has been reached, that there is no way to reverse the trajectory of violence and persecution evidenced so far in the museum.

\section{iv. The Deportation and Boxcar Exhibit}

The museum's exhibition on deportation contains two distinctive elements: a dark, semicircular space in which there is no light save that which comes from a bank of six television screens - and a boxcar. The floors of the semicircular space are cold, dark gray concrete. The walls are bare except where punctuated with steel beams, and there is nowhere to sit. The television screens show pictures of the gates of Auschwitz, of the train tracks approaching Auschwitz, and survivors remembering deportation and the horrifying, long rides in boxcars. At the back of the room, there is a slice of glass that breaks through the concrete, forming a thin, inverted triangular window through which one can see the back of what is clearly one of these very same boxcars. The effect of suddenly seeing up close one of the very same types of railcars so fearfully remembered and documented in the film is startling and unexpected, but one still does not see it in its 
entirety until one emerges from the exhibition on deportation. It looms about seven feet in the air, so one must walk up a steep ramp in order to enter it or take the wheelchair lift up to the train platform if need be. When architect Stanley Tigerman designed the museum, he planned that the railcar would be the centerpiece of the museum, as it would be located in what he called "the cleave," or the central space on which the two halves of the museum are hinged. The cleave is the point at which the museum changes color both inside, in regard to the change in color of the ceiling from black to white, and on the exterior, where one half of the museum is black and the other half white. The railcar's location here is meant to symbolize that with the deportations, especially those that led directly to extermination camps, a juncture or turning point in history is reached: a moment from which the Final Solution is fully implemented and the attempt to destroy completely the Jewish population of Europe and Eastern Europe begins in earnest.

\section{v. Survivor Testimony}

Like the Holocaust Memorial Museum and the Los Angeles museum, the Illinois museum makes extensive use of survivor testimony, but it relies almost exclusively on the testimony of local survivors, which is not the case for the other two museums. All high school students who take tours of the museum hear a live survivor testimony in the museum's Goodman Auditorium, and recorded survivor testimonies are an intrinsic part of the permanent exhibition. Survivors also volunteer in the museum and serve on museum committees, so their voices are heard in many aspects of the museum. As Chief Curator of Collections and Exhibitions Arielle Weininger explained, the permanent exhibition at the Illinois Holocaust Museum "is about survivors, not about the massive 
destruction of European Jewry." ${ }^{, 71}$ Weininger's explanation here highlights a distinctive aspect of the Illinois museum. In many cases, Holocaust survivors conceived of Holocaust museums in their cities, but the museums themselves are thought to be about the Holocaust and about the destruction of European Jewry. For a museum to be about the survivors' stories as they are told against the backdrop of local and Holocaust history marks a departure from what is normative in Holocaust museums. The effect of the museum's prioritization of the survivors is palpable: one leaves the permanent exhibition recognizing survivors' names and voices, having heard them throughout one's tour and in several cases having followed their stories through the museum's narrative. The experience is intimate, for one not only hears the survivors' recorded testimonies but also sees artifacts belonging to those same survivors on display in the museum.

Despite this departure from the norm, however, the original impetus for the Illinois museum did come from survivors. After the war, roughly 8,000 survivors settled in Skokie out of 35,000 Jews in the region, and it is their stories that are told in the museum. One learns about the Holocaust through their eyes and through their voices. As Anita Kassof, the Deputy Director of the Museum of Jewish Heritage: A Living Memorial to the Holocaust in New York City, said, "[this museum and other Holocaust museums] will suffer when the survivors" are gone especially given that live survivor testimony remains the superlative method of "conveying memory authentically."72 Without the survivors, the only available methodologies for delivering testimony to visitors include that which one already finds in museums: recorded testimony, photographs, films, and artifacts. 


\section{vi. The Closing Film}

At the end of one's tour of the museum, there is only one component of the permanent exhibition left to see: a short film, which is shown in a separate room containing enough folding chairs to seat about one hundred people. Barbra Streisand narrates the film, but it relies heavily on the testimony and commentary of Holocaust survivors, of Clemantine Wamariya - a survivor of the Rwandan genocide, and of Carl Wilkins, the only American to remain in Rwanda during the genocide. The film, which will be described in greater detail in a later chapter, connects the Holocaust to the atrocities of today and urges the visitor to take action against contemporary genocide.

\section{C) The Illinois Holocaust Museum \& Education Center: A Tour of the Permanent Exhibition}

To enter the Illinois Holocaust Museum's permanent exhibition, one stands in front of two glass electronic doors that part to reveal a small, dark room that contains several benches and a mostly black-and-white film playing on the wall. The film begins, though, with full-color pictures of street scenes from downtown Chicago: people bustling about on busy streets, trains coming and going, buses and pedestrians navigating crowded urban crosswalks. Soon these scenes fade to show an elderly gentleman standing on a train station platform watching Chicago metro trains pull in and out of the station. The elderly, accented male voice of the film's voiceover says, "My world was pretty much like yours, but then everything changed...We come from a world that was destroyed...How did our world get destroyed? It is the most important story we can ever tell." The film then shows clips from Holocaust-era videos, photographs that flicker 
across the screen, and more voiceovers from what are clearly survivors' voices to illustrate this destruction. The film briefly introduces the concepts of Hitler's rise to power, ghettoization, deportation, and extermination and leaves the viewer with the sense that she is about to hear a deeply personal story about the traumatic events just described.

After watching such a grim and haunting film, it is admittedly a welcome surprise to find that the museum's first exhibit spaces — a section of the museum called "World Before" - are well-lit and bathed in warm colors. These first rooms demonstrate Jewish life before the war through artifacts, photographs, and video testimony, a museological triumvirate employed throughout the permanent exhibition. World Before emphasizes topics such as Jewish education, culture, professional life, home life, life cycle event practices, holidays, and community life. In this exhibition one finds artifacts such as a menorah, Shabbat candlesticks, Kiddush cups, a dreidel, a spice box, and a wimple, and in the background, layered overtop the many artifacts, photographs, and text panels, are the voices of survivors. On a flatscreen television embedded in the wall of World Before, Holocaust survivors tell stories about their lives before the war. "I still remember the smell of my mother's chicken soup," says one woman. Another says, "My mother had a white shawl that she used to wear to synagogue on Yom Kippur, and after services, she would wrap us children in it and bless us." The elderly woman's voice breaks into tears as she explains, "And I still miss that to this day. You miss that...forever." The implication is that the survivors lost their mothers during the Holocaust and under terrible circumstances, so their mourning is both the grief of a child for a beloved parent and the grief of a Jewish child whose rich Jewish religious, community, and family life was torn 
apart. Although the testimonies here say nothing of deportations, starvation, or death camps, they are heart-breaking, deeply troubling, and thoroughly evocative of the irrevocable loss that the Jewish community experiences at the hands of the Nazis. Like the introductory film, these testimonies hint at the information that is to come later in the museum, setting an eerie and hauntingly personal tone.

This change in tone is appropriate here, for the next section of the museum briefly explains the rise of Nazism, then devotes significant space to its exhibition "Life Under the Swastika." Here one learns about what Jewish life was like under Nazi rule, how Jewish families decided to stay in Germany or not, Nazi propaganda and Nazi indoctrination techniques, the Berlin Olympics, how the Nazis took control of Jewish institutions and isolated German Jews, and the 1938 Evian Conference-at which many countries criticized Germany for its treatment of Jews but still did not offer to accept Jewish refugees themselves. One is left with a keen awareness of how difficult the 1930s were for Jews, whether because they were deciding whether to send their children on the kindertransport or because their very livelihoods were being taken away. An exhibition space whose walls are completely lined with Jewish passports further demonstrates these hardships, for on each card, women's middle names are "Sara" and men's middle names are "Israel" in accordance with a Nazi regulation that required Jewish men and women with names of "non-Jewish" origin to be labeled in this way in order to facilitate their being easily identified as Jews. The survivor testimony video played in this exhibit includes survivors' memories about the kindertransport, watching Nazi marches from their apartment windows, and being excluded from German society yet embraced by a 
Jewish community that "came together to provide" the activities and resources that Jews still needed and wanted. One survivor remembers falling down on the playground at her school and getting a large gash on her leg, to which her teacher said, "I'm not going to touch dirty Jewish blood."

After gaining an understanding of both German hostility toward Jews and of the world's resistance to helping them, the museum illustrates these issues further with its exhibits about Kristallnacht—including a floor made of cracked and broken glass—and the world's response to that event. With large reproductions of the front pages of the New York Times, the Chicago Tribune, and the Los Angeles Times-all reporting on Kristallnacht - it is easy to assume that people in the United States knew about the event and would then have cared about the plight of German Jews. The museum tempers this thought by providing information about "Paper Walls" and "The Voyage of the St. Louis," illustrating how difficult it became for Jews to leave Germany and how hostile America was to the idea of permitting Jewish refugees to enter the country.

It is with this sense of doom and frustration in the background that the museum begins to tell the history of the period of 1939 to 1945 . In quick succession, one moves through exhibitions on the German invasion of Poland and other countries, on how France and England declare war on Germany, on the many groups of people—not just Jews—whom the Nazis targeted. An entire panel is devoted to the subject of Nazi "euthanasia" or "mercy killing," its murder of 200,000 handicapped and mentally disabled German citizens. A large photograph of Hitler and his co-conspirators standing in front of the 
Eiffel Tower depicts the spread of Nazi racism, as does an exhibition of yellow Star of David badges labeled with the word "Jew" in multiple languages. One learns about underground groups hiding Jews, especially children. The overall effect of this section of the museum is to impress upon the visitor the depth and level of Nazi persecution. There is the sensation of onslaught, that the Nazis took control over many groups of people and many countries quickly and with ferocity—even murdering their own in the name of racial purity.

A lengthy exhibit on ghettoization illustrates both this ferocity and Jewish attempts to overcome it. The cobblestone floors of the dark exhibit space are paired with brick and barbed wire to illustrate the prisonlike atmosphere of the ghettos, and the survivor testimony video here documents the experience of being relocated to ghettos and of life in the ghettos. One survivor remembers that her parents made her wear layer upon layer of clothing so that she could take more with her to the ghetto. Exhibits on the Warsaw ghetto uprising, the Ringelblum milk canisters, and Jews' attempts to create Jewish religious and cultural life even within the confines of the ghettos and the terrible living conditions there attempt to demonstrate that Jews made efforts to retaliate against the Nazis both nonviolently and violently.

Despite providing this more personally inspiring and fortifying information, however, the museum quickly brings the visitor to an even more grim and horrifying aspect of Holocaust history: Nazi policies of mass murder - the Einsatzgruppen and the Final Solution — and the atrocities committed at Babi Yar, as described earlier. The historical 
trajectory of mass murder now begins to unfold as the museum commences its explanation of deportation with a panel called "Deception" in which "The Hoax of Theresienstadt" is described. Children's artwork from the camp anchors the textual information presented, and film clips excerpted from a staged Nazi film of life in Theresienstadt accompany survivor testimony video. In the video, survivors remember being told that they were being "relocated," then knowing something was wrong when they saw the trains, the Nazi soldiers, and the dogs. One survivor reflects upon how hard it was to believe that an "industry of death was possible." The survivor's words here are rendered even more haunting in the next section of the museum: Deportation.

Though it might seem ironic that the color shift from dark to light occurs just as deportees are arriving in the camps, the museum's approach to the subject of deportation to the camps is to inform the visitor not just about death and victimization but also about survival and resistance. Perhaps the color change is meant to echo this curatorial decision, or vice-versa. The exhibition space on the camps does include extensive information on the Nazi death camps through text panels, maps, a model of Auschwitz Birkenau, and artifacts such as a camp uniform, a model of Belzec kept in a darkened room that is haunted by the voice of Rudolf Reder, one of the few survivors of that camp, and photographs from Auschwitz. It also again presents information on Jewish resistance. The exhibition includes information on Jewish partisans, armed resistance in the ghettos, and a survivor testimony video in which survivors remember the Warsaw Ghetto Uprising. Artifacts displayed here include a backpack that Boris Kacel used during his escape from Buchenwald; a Jewish prayer book that two Jewish men carried 
through various ghettos and camps; a clothespin carved from a tree in Buchenwald; a straw purse made in the Gurs transit camp in October of 1940; the diary of Aron Derman, kept while in hiding as a partisan in the forests of Poland; and a bra that Hannah Messinger made from bits of cloth and string in the Marzdorf labor camp in Germany in 1945. The artifacts humanize the destruction documented in this exhibition without attempting to override the integrity of the tragedy described therein, a difficult balance to achieve.

The next few sections of the permanent exhibition attempt to explain the political and social climates extant in other parts of the world while Jews and others were being imprisoned and murdered in the camps. In an exhibition entitled "Getting the Word Out," one reads about Jan Karski, a Polish resistance fighter whose pleas and eyewitness accounts fell on the deaf ears even of British Foreign Secretary Anothony Eden and United States President Franklin Roosevelt. The message taught here regarding the world's response to information about the camps leaking out of Europe is that it was largely ignored, that the allies fought the world war but did not fight the war against Hitler - prioritizing their own interests over the interests of European Jews who were reportedly being murdered at a rapidly accelerating pace. Another element acknowledged in this portion of the museum is that of collaboration. The museum points out that Nazi collaborators throughout Europe betrayed Jews repeatedly, informing the Nazis where Jews were hiding or simply turning their backs on former Jewish neighbors and colleagues, refusing to help. The world's response, then, was to disregard information about the plight of European Jewry under Nazi rule, to collaborate with 
Hitler by cooperating with the Nazis, and to betray Jews on the individual level as well. The museum tempers this message slightly in its next section, "Rescuers," almost as if to relieve the viewer from dwelling too long on the uncomfortable notion of complicityeither American or European. The exhibition includes photographs of the men and women who did help Jews during the Holocaust. There are photographs of and information about Irina Sendler, Mustafa Hardaga, and the scores of Danish fisherman who helped many Danish Jews escape to Sweden. A video in the exhibit tells the stories of Oskar Schindler and Chiune Sugihara, and it plays testimony of survivors remembering the people who hid or saved them during the war. Prominently displayed are a Righteous Among the Nations Certificate and Medal of the late Franciska and Hipolit Gorski, who hid siblings Irene and Aron Elster, now of Chicago.

Next the permanent exhibit moves from the subject of the Righteous Among the Nations to a small exhibition space on the death marches that took place as Allied forces encroached upon the camps and reveals a map of the destruction of Jewish communities during the Holocaust. Like all other maps in the permanent exhibition, this one too is clear, easy to interpret, and succinct. On this map, there is a bar graph for each country in which Jews died during the Holocaust, with the graph indicating how many Jews lived in a given region before the war and how many actually survived the war. The data is starkly presented and sobering. Equally as sobering is the next section of the museum, "Liberation." Here video plays again, but the testimony is not that of Holocaust survivors - it is the testimony of the liberators, whose words express in raw and deeply honest terms the horrors that they discovered. Opposite the video screen, a greenish- 
brown military jacket hangs next to United States military identification tags, both of which artifacts originally belonged to Chicago native and concentration camp liberator Jules Barrash.

Survivor testimony about the liberation can be found, however, in the next section of the museum, "Return to Life," a section that begins the last phase of the museum, in which one learns about how survivors resettled after the war. In the testimony shown here, survivors discuss not only the moments of their respective liberations but also how they tried to get home and what they discovered if they did finally reach home. There is also a station at which one can pick up earphones and listen to Chicago-area psychologist Dr. David Pablo Boder interviewing survivors in the displaced persons camps immediately after the war. In all of the testimonies, the grief and distress are palpable, serving as intimate reminders of the survivors' collective and irretrievable losses. The impact of the testimony and of the descriptions of the terrible living conditions that Jews suffered in the displaced persons camps becomes even more intense against the backdrop of one of the museum's most affecting exhibits: two walls of photographs of orphaned children from the Kloster Indersdorf Displaced persons camp, each child holding up a name card to help surviving family members locate him or her. It is breathtakingly sad to look at the faces of the children, to read their names, and to doubt that they were ever reunited with their families.

After being exposed to this sadness and grief, there is a bit of consolation to be found in the museum's exhibitions about the Nuremberg Trials and about the Simon Wiesenthal 
Center's work to hold Nazi murderers accountable for their crimes, though the museum does not devote extensive space to this subject. More attention is devoted to the subject of Jewish immigration to Palestine, the Aliyah Bet and clandestine attempts to immigrate to Israel, the birth of the state of Israel, and survivors' acclimation to and participation in Israeli life. A glass case holding artifacts such as a traditional Israeli dress with Yemenite embroidery and a Sephardic Torah case demonstrate further attempts of Jews to participate in making new lives for themselves in Israel. Another television screen shows survivors recalling their respective arrivals in Israel, where "no one wanted to hear about the Holocaust." One survivor remembers how deeply she internalized the sadness of her wartime experiences after arriving in Israel. She explains that one day, her children's preschool teacher told her that she needed to speak with her about a problem. "Your children don't smile," said the teacher. The survivor recalls that she after the Holocaust, she had "forgotten how to smile" and had to "practice in the mirror" how to smile so that she could pass that ability on to her children.

The museum also explains that many Holocaust survivors settled in the United States as well, and it covers an entire wall with certificates of naturalization belonging to Jews who had immigrated there. There are multiple picture of Jews settling in Chicago, but there is also acknowledgement that despite America's claims of liberty and equality, Jews were still not always welcome in some communities or in certain groups. In a poignant example of this point, the museum provides a detailed description of the "Nazi March on Skokie," as discussed earlier in this section. At this point in the museum, there is also a brief exhibit on "Survivor Empowerment," or how survivors around the world began to 
speak out about their experiences during the Holocaust, build memorials, and attend the first worldwide conference of Holocaust survivors in Jerusalem and other conferences like it. One's tour ends with a closing film about contemporary genocides, a film that will be described in greater detail in Chapter Four, after which one emerges into a bright, white lobby and finds the museum's gift shop.

\section{Conclusion}

This chapter has sketched out the elaborate historical backdrop out of which Holocaust museums in the United States arose and described in extensive detail the Holocaust Memorial Museum, the Los Angeles museum, and the Illinois museum. The museums' architectural elements, artifacts, and audiovisual elements — also described here —all participate in effecting remembrance and in telling the story of the Holocaust. It is arguably this latter aspect of the museums that proves most significant, for while Holocaust museums are hardly the first museums to tell a story, they are the first museums to tell the story of the Holocaust. In so doing, the museums create a new narrative of the Holocaust that is different because it is not literary or filmic but museological, and the notion of a museological Holocaust narrative implies concomitantly that while it may share elements characteristic of literary or filmic Holocaust narratives, it may also diverge from them.

In her book From Knowledge to Narrative: Educators and the Changing Museum, the cultural historian and former museum professional Lisa C. Roberts writes about the inherently subjective nature of the museum narrative. Roberts argues, "In any given 
museum, visitors will probably encounter the same raw material: an entryway, exhibits and perhaps a restaurant or gift shop. However, each will come away with an individually unique experience and interpretation because every visitor is engaged in constructing a narrative about what he or she sees." ${ }^{, 73}$ Roberts points to a key tension here: that while it is valuable for a visitor to feel a personal relationship to the museum and to derive something personal from its narrative, the unpredictable nature of the visitor's internally constructed narrative means that the museum must find a way to communicate the key points of its story in an unambiguous way if it wants certain pieces of information to be unambiguous. In a Holocaust museum, there is an ethical pressure placed on this juncture between the museum's narrative and the visitor's created narrative, for the museum prides itself on providing the visitor with accurate information on such topics as the history of the time period, the rise of anti-Semitism, and human rights. There is no accommodation in such a narrative for, to name one more extreme example, Holocaust denial. The narrative's rejection of such an element represents what literature scholar Adam Zachary Newton describes as the "common, though sometimes overlooked, fact about narrative: that the story it tells is a story of storytelling." ${ }^{.74}$ In the museum, what the narrative does not say can be just as significant as what it does say; in that case, as Newton writes, the story that the museum presents makes a statement about how the story of the Holocaust is meant to be told museologically. According to the analysis of the three United States museums presented in this chapter, a Holocaust museum is to tell its story through art, architecture, testimony, artifacts, photographs, technological devices, exhibit labels, and geography. The presence of these many narrative vehicles presents both a rich opportunity for vibrant, detailed storytelling and 
the problem of having many narrative variables. If the museum has a deontic concern with accuracy, then it seems questionable for it to rely upon a multi-variable narrative. The tension here, however, as Newton explains, is that if a narrative sublimates all variables, then it flattens, rectifies, and thus fictionalizes its ethical perspective. ${ }^{75} \mathrm{~A}$ reductionist narrative strategy that posits a singular ethic creates a parallel, false storyexactly the opposite of the claim on truth that the museums want to make unequivocally. The professors of English literature and Holocaust Studies Neil Levi and Michael Rothberg write about this very problem in their anthology, The Holocaust: Theoretical Readings, stating that "as a field of Holocaust representation, narrative is distinguished from poetry and visual culture by the questions it raises about the status of fictions about the Holocaust and about the cognitive, ethical, and political implications of specific narrative forms." ${ }^{, 76}$ The three chapters that follow from here will examine just this: how Holocaust history has been processed distinctively in the museum in response to cognitive debates on the subject, ethical debates, and contemporary debates.

1 Jonathan Sarna, American Judaism: A History (New Haven and London: Yale University Press, 2004), 275.

${ }^{2}$ Historian Jonathan Sarna addreses these shifts in American Jewish life in his chapter "Renewal" (272-355) in his book American Judaism: A History (New Haven \& London: Yale University Press, 2004).

${ }^{3}$ An early version of her work on the subject, "A Reporter at Large: Eichmann in Jerusalem-1," appeared in the February 16, 1963 issue of The New Yorker. In the book 
that followed, Eichmann in Jerusalem: A Report on the Banality of Evil (Penguin Books, 1963), Arendt makes the now-infamous claims that Eichmann was not a "monster" (276) but rather a boring person, that the form of "evil" in which he engaged was at its heart utterly "banal" (252), that he had no real reason for his actions than wanting to better himself and advance in his workplace, and that one reason behind the death of so many Jews during the Holocaust was the cooperation of Jewish leaders with the Nazis in certain situations.

4 Sarna, American Judaism, 310.

${ }^{5}$ Gavriel D. Rosenfeld, Building After Auschwitz: Jewish Architecture and the Memory of the Holocaust (New Haven and London: Yale University Press, 2011), 148.

${ }^{6}$ For a broad look at this subject, see Michael Grunberger's From Haven to Home: 350 Years of Jewish Life in America, Library of Congress: 2004.

7 Jacob Neusner, Death and Birth of Judaism: The Impact of Christianity, Secularism, and the Holocaust on Jewish Faith (New York: Basic Books, Inc., 1987), 275.

${ }^{8}$ Rosenfeld, Building After Auschwitz, 148.

${ }^{9}$ Ruth Seldin, “American Jewish Museums: Trends and Issues," in American Jewish Yearbook (1991): 75.

${ }^{10}$ The following discussion of the events of 1978 is based on Edward T. Linenthal's chronicle of this time period in the introduction to Preserving Memory: The Struggle to Create American's Holocaust Museum (New York: Columbia University Press, 1995).

${ }^{11}$ Linenthal, Preserving Memory, 11.

12 One year earlier, however, in 1977, NBC released a mini-series called Roots after Alex Haley's novel. Faith Davis Ruffins explains that Roots singlehandedly educated the American public about the history of slavery in its own country, caused interest in genealogy to soar, prompted a surge in interest in Black history, and enabled African American museums in cities such as Detroit and Chicago to acquire public funding. Efforts to propose that an African-American museum be built on the Mall in Washington never came to fruition, and it was only in 2012 that construction of such a museum finally began there. ("Revisiting the Old Plantation: Reparations, Reconciliation, and Museumizing American Slavery," in Museum Frictions: Public Cultures/Global Transformations, ed. Ivan Karp et al. Durham and London: Duke University Press, 2006, 396.)

${ }^{13}$ Linenthal, Preserving Memory, 12.

${ }^{14}$ Linenthal, Preserving Memory, 12.

${ }^{15}$ Rosenfeld, Building After Auschwitz, 148.

16 See Rochelle G. Saidel's chapter, "Holocaust Memorialization on the U.S. Government's Agenda," in her book Never Too Late to Remember: The Politics Behind New York City's Holocaust Museum (New York and London: Holmes \& Meier, 1996) for a discussion of President Carter's efforts to establish the President's Commission. Saidel's book focuses on the thirty-odd year history of failed attempts to build a Holocaust memorial in New York City, so she offers that context as being an important component of Carter's decision-making process.

${ }^{17}$ Linenthal, Preserving Memory, 24.

18 Stuart Z. Charme, "Newly Found Jews and the Politics of Recognition," Journal of the American Academy of Religion, Vol. 80, Number 2 (June 2012): 388. 
${ }^{19}$ The Vietnam Veterans Memorial was built at the same time that USHMM was being planned, but it was completed more than a decade earlier - in 1982. Museum scholar James E. Young calls it a "counter-monument" for the way that its premise and its architecture challenge traditional notions of the monument as well as "the capital's [Washington, D.C.'s] more neo-classic, triumphal memorial statuary." For the full text of an interview with him on this subject, see Jennifer Geddes's "An Interview with James E. Young" in The Hedgehog Review: Critical Reflections on Contemporary Culture, "The Uses of the Past," Summer 2007, Volume Nine, Number Two (2007): 68-72. Other valuable critiques of the memorial include Robert Harbison's The Built, the Unbuilt, and the Unbuildable: In Pursuit of Architectural Meaning (Cambridge, Massachusetts: The MIT Press, 1992), 64, in which the author cites its "unemphatic presence" that is like a "seething wound" in the earth. The art historian Lisa Saltzman writes that "if any work of visual art has come to emblematize and influence the cultural activity of memory in the present, it is Maya Lin's 1982 Vietnam Veterans Memorial" because "the prematurely extinguished lives of soldier after soldier can only be registered as a refusal to represent them visually, their identities acknowledged instead in the unrelenting inscription of name after name upon the unforgiving surface of the marble funereal slabs" (Making Memory Matter: Strategies of Remembrance in Contemporary Art, Chicago \& London: The University of Chicago Press, 2006), 7. Here Saltzman reiterates, in the context of Vietnam War memorialization, the difficulty of representing visually the deaths of thousands.

${ }^{20}$ For more information about the importance of the site of the USHMM, see Chapter Nine, "Dislocation: The US Holocaust Memorial Museum" in John Lennon and Malcolm Foley's Dark Tourism: The Attraction of Death and Disaster (Cengage Learning, 2010); Chapter Four, "Auschwitz, Yad Vashem, and Washington, DC: An Overview," in Isabelle Englehardt's A Topography of Memory: Representations of the Holocaust at Dachau and Buchenwald in Comparison with Auschwitz, Yad Vashem, and Washington, D.C. (Bruxelles: Peter Lang, 2002); Chapter Two of Edward T. Linenthal's Preserving Memory: The Struggle to Create America's Holocaust Museum (New York: Columbia University Press, 1995); Chapter Twelve, "Memory and the Politics of Identity: Boston and Washington, D.C.," in James E. Young's The Texture of Memory: Holocaust Memorials and Meaning (New Haven and London: Yale University Press, 1993); and James Ingo Freed's article, "The United States Holocaust Memorial Museum," in James E. Young's collection The Art of Memory: Holocaust Memorials in History (Munich: Prestel-Verlag, 1994). These texts discuss issues that arose over the selection of the Washington Mall as the site for the museum, including but not limited to questions about the propriety of memorializing the World War II deaths of Europeans before there was a memorial on the mall to Americans who died at the time and whether the museum belongs in Washington at all given that other American cities were home to much larger populations of Jewish immigrants.

${ }^{21}$ Joan Branham, "Mapping Tragedy in the United States Holocaust Memorial Museum," in The Tragic in Architecture, ed. Richard Patterson (John Wiley \& Sons Ltd., 2000): 5459.

${ }^{22}$ There was a shadow cast over this feeling of respect, however, in that the museum's prioritization met with the frustration of the African-American community, which was 
"frustrated by the absence of commemoration of their traumatic history on the Mall in Washington," as Michael Rothberg explains in "Fractured Relations: The Multidirectional Holocaust Memory of Caryl Phillips," in After Testimony: The Ethics and Aesthetics of Holocaust Narrative for the Future, ed. Jakob Lothe, et al. (Columbus, Ohio: Ohio State University Press, 2012), 332. It is only now, as of this writing, that the African-American community will finally have its long overdue recognition on the mall in the form of the Smithsonian National Museum of African American History and Culture. This museum will occupy the last available land for building on the mall, adjacent to the Washington Monument, and is scheduled to open in 2015.

${ }^{23}$ Kirk Savage, Monument Wars: Washington, D.C., the National Mall, and the Transformation of the Memorial Landscape (Berkeley, Los Angeles, and London: University of California Press, 2005), 261.

${ }^{24}$ Savage, Monument Wars, 285.

25 The AP, "Design of Holocaust Museum Unveiled," New York Times, May 11, 1985.

26 The AP, "Design."

27 The AP, "Design."

${ }^{28}$ Joseph Giovanni, "Design for the U.S. Holocaust Museum Is Ready," New York Times, May 21, 1987.

${ }^{29}$ The AP, “Agency Approves Plan For Holocaust Museum," New York Times, July 31, 1987.

30 The AP, “Agency Approves."

${ }^{31}$ Judith Miller, "Holocaust Museum: A Troubled Start," New York Times, April 22, 1990.

${ }^{32}$ Miller, "Holocaust Museum."

${ }^{33}$ Holocaust historian Lucy S. Dawidowicz argued instead for a memorial to be built in New York City, home to a significant portion of the Jewish population of the United States - much more so than Washington, D.C. She feared that a "grandiose museum might give the appearance of "celebrating rather than commemorating the Holocaust.", (Miller, "Holocaust Museum") While few others shared her concern to the degree that it halted progress on the museum's progress, Dawidowicz's fear was not without reason. As Holocaust films, literature, memorials, and museums have proliferated in the years since the Holocaust Memorial Museum was in its planning stages, their collective prominence in American popular culture draws and deserves criticism for "popularizing" the atrocity.

${ }^{34}$ Victoria Newhouse, “Is 'The Idea of a Museum' Possible Today?” Daedalus, Vol. 128, No. 3, America's Museums (Summer, 1999), 321. Here Newhouse describes succinctly what was a radical change in the notion of the museum from the celebratory to the disturbing. While Washington, D.C. abounds with memorials, the United States Holocaust Memorial Museum was the first memorial museum in the city, and it set a precedent for other museums with memorial overtones to find homes on the Mall, namely the Smithsonian's National Museum of the American Indian and its forthcoming National Museum of African American History and Culture.

35 The historian Tim Cole critiques the museum's choice here in his book Selling the Holocaust: From Auschwitz to Schindler-How History is Bought, Packaged, and Sold (New York: Routledge, 2000). He writes that beginning with the liberation means that 
"rather than revealing the confusing, banal complexity of an event of ludicrous proportions, it is presented as an event which can not only be comprehended, but also as one which can be understood" (153). Cole is also alluding here to the idea that if one is provided with the relief of the liberation prior to learning about the history of the Holocaust, then that sense of knowing that it would end color's one's perception. In real time, no one knew when the war would end or when or if the camps would be liberatedcertainly not the victims. ${ }^{36}$ Mark Godfrey, Abstraction and the Holocaust (New Haven: Yale University Press, 2007).

${ }^{37}$ For another perspective on the use of abstract representation in a Holocaust museum, see Asher Biemann's translation of The Forward's interview with Luca Zevi, "From Mussolini's Estate to Shoah Memorial: A Conversation with Luca Zevi, Architect of Rome's Holocaust Museum," accessed July 17, 2013, http://forward.com/articles/140533/from-mussolini-s-estate-to-shoah-memorial. Zevi says, "from the modern movement I have learned the need to express architecturally the functions and signifiers that belong to the inner character of a building without any particular obedience to the compositional rules and proper stylistic languages of the past." Here Zevi describes his desire to build a Holocaust museum that does not follow the architectural tenets of any one architectural style. Instead, his design for the Rome museum is a black box inscribed with the names of Italians who were deported during the Holocaust - a shape unlike that of any other Holocaust museum in the world.

${ }^{38}$ Nicholas Wolterstorff, Art in Action: Toward a Christian Perspective (Grand Rapids, Michigan: William B. Eerdmans Publishing Company, 1980), 174.

${ }^{39}$ Wolterstorff, Art in Action, 172.

${ }^{40}$ Monica Bohm-Duchen's collection of essays, After Auschwitz: Responses to the Holocaust in Contemporary Art (London: Lund Humphries Publishers Limited, 1995), includes an especially thorough selection of images of contemporary-artistic interpretations of the Holocaust. The works documented include memorials and monuments, paintings, drawings, and sculptures created from found objects, demonstrating the wide array of materials and forms that contemporary artists employ in their pursuit of self-expression and Holocaust memorialization.

${ }^{41}$ Stephen C. Feinstein, "Witness and Legacy," in Witness \& Legacy: Contemporary Art About the Holocaust, ed. Stephen C. Feinstein (Minneapolis, Minnesota: Lerner Publications Company, 1995), 9.

${ }^{42}$ Feinstein, Witness \& Legacy, 9.

43 In her book The Era of the Witness (Ithaca and London: Cornell University Press, 2006), Annette Wieviorka discusses the change in approach to eyewitness testimony that takes place after the 1960 trial of Nazi war criminal Adolf Eichmann, in which eyewitnesses played a key role. She writes that after the trial, "survivors, whose stories were avoided during the postwar years, became respectable and respected persons in their very identities as survivors... [that there was now] no shame, either collective or individual in being a victim of the Holocaust" (102). Without this transformation in the attitude toward survivors and their stories, museums like the Holocaust Memorial Museum simply would not have access to an extensive body of recorded Holocaust survivor testimony in the way that they do today. The literary critic and Co-Founder and 
Project Director of the Fortunoff Video Archive for Holocaust Testimonies at Yale University, Geoffrey Hartman, refers to this collection of testimonies as a "sacred deposit" in which the interviewer, the videographer, and ultimately, the viewer, participate in a "return of trust" with the survivor, an exchange of mutual respect and consideration that recognizes the trauma so evident in the survivors' words and experiences (Scars of the Spirit: The Struggle Against Inauthenticity, Palgrave Macmillan, 2002, 76-78).

${ }^{44}$ Dori Laub, "Testimony as Life Experience and Legacy," in The Power of Witnessing: Reflections, Reverberations, and Trace of the Holocaust, ed. Nancy R. Goodman et al. (New York and London: Routledge, 2012), 59.

${ }^{45}$ Crispin Paine, Religious Objects in Museums: Private Lives and Public Duties (London and New York: Bloomsbury, 2013), 52-53.

${ }^{46}$ Eilean Hooper-Greenhill, Museums and the Interpretation of Visual Culture (London and New York: Routledge, 2000), 14.

47 Jeffrey Karl Ochsner, "Understanding the Holocaust through the U.S. Holocaust Memorial Museum, Journal of Architectural Education (1984-), Vol. 48, No. 4 (May, 1995), 240.

48 Tim Cole, Selling the Holocaust: From Auschwitz to Schindler: How History is Bought, Packaged, and Sold (New York: Routledge, 2000), 160.

49 "Collections," National Museum of the American Indian, accessed August 26, 2013, http://nmai.si.edu/explore/collections.

50 "Art of the Americas: About the Collections," Museum of Fine Arts Boston, accessed August 26, 2013, http://www.mfa.org/collections/art-americas.

51 “The Hershey Story Collections," The Hershey Story, accessed August 26, 2013, http://www.hersheystory.org/collections.

52 In his book, Selling the Holocaust: From Auschwitz to Schindler: How History is Bought, Packaged, and Sold (New York: Routledge, 2000), Holocaust historian Tim Cole discusses the Holocaust Memorial Museum's concerns about Holocaust denial. He writes that in the museum, "there is an obvious concern on the part of the exhibition designers with authenticity" and that it is "a place which - through the presentation of material evidence - aims to convince us of the reality of the murder of six million European Jews in the face of the claims of Holocaust deniers" (160). Denial is not a problem that other museums confront: no one denies the slaughter of the Native Americans or that Rodin sculpted "The Thinker" or that Milton Hershey perfected the art of mass-producing chocolate. It is only Holocaust museums that must imbue their artifacts with the moral responsibility of providing evidence of the existence of an historical event.

${ }^{53}$ Rosenfeld, Building After Auschwitz, 283.

${ }^{54}$ E. Randol Schoenberg, interview with the author, June 16, 2013.

55 "Mission Statement," Los Angeles Museum of the Holocaust, accessed August 26, 2013, http://www.lamoth.org/the-museum/mission-statement.

56 "Pan Pacific Park: Memorial to the Munich Olympic Victims," Los Angeles Museum of the Holocaust, accessed August 26, 2013, http://www.lamoth.org/exhibitions/virtualtour/pan-pacific-park. 
57 "Shopping at the Grove," The Grove, accessed August 26, 2013, http://www.thegrovela.com/shop.php.

58 "Inside the Museum: Holocaust Monument/ Martyr's Memorial," Los Angeles

Museum of the Holocaust, accessed August 26, 2013, http://www.lamoth.org/exhibitions/virtual-tour.

${ }^{59}$ E. Randol Schoenberg, interview with the author, June 16, 2013.

${ }^{60}$ Eilean Hooper-Greenhill writes about the effect of rapidly advancing technology on museum practice in her book Museums and the Shaping of Knowledge (London and New York: Routledge, 1992). She explains that "new technology is being used in displays to fragment the meaning of the artefact and to introduce many perspectives...In the past, the object on display was accompanied with a label that fixed it in a monolinear frame of reference. A chair was 'Oak, Seventeenth Century'... The human, social, and cultural contexts of these artefacts were rendered invisible by these strategies. Now the many frames of reference that can contextualise material things are displayed along with the things themselves" (204-205). According to Hooper-Greenhill, technology serves as a positive force that makes possible museums' increased capacity for content delivery and contextualization.

61 "Museum Themes," Los Angeles Museum of the Holocaust, accessed August 26, 2013, http://www.lamoth.org/exhibitions/museum-themes.

${ }^{62}$ E. Randol Schoenberg, interview with the author, June 16, 2013.

63 "Inside the Museum: Life After Liberation," Los Angeles Museum of the Holocaust, accessed August 26, 2013, http://www.lamoth.org/exhibitions/virtual-tour.

${ }^{64}$ Lisbeth Levine, "Skokie to Open New Holocaust Museum: Site of Neo-Nazi March That Launched Shoah Education," The Jewish Daily Forward, April 8, 2009, accessed August 26, 2013, http://forward.com/articles/104682/skokie-to-open-new-holocaustmuseum.

${ }^{65}$ Lillian Polus Gerstner, interview with the author, July 3, 2013.

${ }^{66}$ According to Lillian Polus Gerstner, July 3, 2013.

67 "Completed Work: Holocaust Museum," Tigerman McCurry, accessed August 26, 2013, http://tigerman-mccurry.com.

${ }^{68}$ Edward Keegan, "Illinois Holocaust Museum: Chicago/ Tigerman McCurry Architects," Architect: The Magazine of the American Institute of Architects, April 6, 2010.

${ }^{69}$ Edward Keegan, "Illinois Holocaust Museum: Chicago/ Tigerman McCurry Architects." Architect: The Magazine of the American Institute of Architects, April 6, 2010.

${ }^{70}$ See museum handout entitled "Museum Highlights," available on-site at the Illinois Holocaust Museum and Education Center.

${ }^{71}$ Arielle Weiniger (Chief Curator, Collections and Exhibitions, Illinois Holocaust Museum and Education Center), in discussion with the author, Illinois Holocaust Museum Education Center, August 7, 2012.

${ }^{72}$ Anita Kassof (Deputy Director, Museum of Jewish Heritage: A Living Memorial to the Holocaust), in conversation with the author, Museum of Jewish Heritage, New York City, August 10, 2012. 
${ }^{73}$ Lisa C. Roberts, From Knowledge to Narrative: Educators and the Changing Museum (Washington and London: Smithsonian Institution Press, 1997), 137.

${ }^{74}$ Adam Zachary Newton, Narrative Ethics (Cambridge, Massachusetts and London, England: Harvard University Press, 1995), 3.

${ }^{75}$ Newton, Narrative Ethics, 37.

${ }^{76}$ Neil Levi and Michael Rothberg, The Holocaust: Theoretical Readings (New Brunswick, New Jersey: Rutgers University Press, 2003), 325. 


\section{CHAPTER FOUR: HOLOCAUST UNIQUENESS AND HOLOCAUST MEMORY}

In the decades immediately following the Holocaust, a scholarly debate emerged regarding whether the Holocaust could be considered "unique" or unprecedented in world history. At first the very incomprehensibility of the Holocaust drove the arguments, as the Jewish community struggled to understand, assess, and respond to such an enormous tragedy. Over time, however, other developments began to alter the nature of the debate and the way that scholars were coming to understand the Holocaust. ${ }^{1}$ In the 1970 s and 1980s, there arose two major tendencies that affected perceptions of the Holocaust: the tendency to historicize the Holocaust and the tendency to politicize it. The argument that the Holocaust is unique became, then, a reaction against the historicization of the Holocaust and a defensive response designed to protect the Holocaust from the diluting, distorting forces of such elements as "functionalism, modernity, and genocide", and "dejudaizing...Americanizing... and normalizing.", The idea was to prevent the Holocaust from being subsumed into American culture, from being compared to other atrocities, from being used for political or utilitarian goals, and from being distanced from its Jewish nature. As these issues were being examined, heated arguments over whether the Holocaust can be seen as unique ensued, with prominent scholars arguing vehemently for their respective positions. As the debate continued it became less scholarly and increasingly polemical, emotional, contentious, and unfruitful. A resolution was never reached, but since the late 1990s, the debate has receded and no longer dominates Holocaust scholarship in the way that it once did. 
A lack of dominance in the scholarship does not mean, of course, that there are no remnants of the debates. The five Holocaust museums examined in the previous chapters of this dissertation-Yad Vashem, the Jewish Museum Berlin, the United States Holocaust Memorial Museum, the Illinois Holocaust Museum \& Education Center, and the Los Angeles Holocaust Museum — demonstrate the diversity of location, architecture, and emphasis that exists among Holocaust museums worldwide. The question remains as to what influence the debates over uniqueness and memory have had on the museums. This chapter chronicles the nuances of these two debates and then, in the concluding statement, examines whether any remnants of the debates can be identified in Holocaust museums today.

\section{The Uniqueness Debate}

The uniqueness debate raises questions about how broadly or how narrowly to define what has come to be called "the Holocaust;" the problem of comparing the Holocaust to other genocides; and the question of how to address the Holocaust in Jewish life and culture in light of whether the Holocaust is to be seen as unique or universal. ${ }^{4}$ The latter two of these three issues remain of dominant concern today for two reasons. The first reason is that genocides have continued to take place since the time of the Holocaust, increasing the pressure on Holocaust scholarship to take into account arguments about how to represent the Holocaust in the face of these other atrocities and to engage in the task of comparison carefully and sensitively. Second, the problem of how to represent the Holocaust remains of concern because it continues to be addressed in many forms to this day—literary, scholarly, filmic, testimonial, and museological to name a few—all of which bear responsibility for accurate, ethical representation of the Holocaust that 
influences how the American public learns about and comes to understand the Holocaust. Unlike the other forms of remembrance mentioned here, however, only scholars in the field and Holocaust museums have been considering both the issue of Holocaust representation and the fact of ongoing genocides simultaneously. ${ }^{5}$

\section{A) Definition of Terms}

The term "Holocaust" was not originally used to refer to the genocide of eastern European Jews during World War II. In fact, immediately after the war, there was no widely-used term for the genocide in the way that is known today. Over time, though, there emerged a need for a specific term with which to refer to the catastrophe, and there was the idea that the event required a unique descriptor. Eventually three terms emerged to describe the atrocity that the Nazis had perpetrated: Chorban (or also Churban), Shoah, and Holocaust. Chorban is a Hebrew word that means "destruction," and Eastern European Jews first used it in the early 1940s. ${ }^{6}$ Jews also began to use the Hebrew term sho'ah, or 'catastrophe,' to refer to the disaster. The term Shoah is widely used in Israel and in Europe, therefore the official term for Holocaust Remembrance Day is Yom haSho' $a h^{7}$ The term used most commonly in the United States, however, is "Holocaust." This term has Latin and Greek origins and can be found in the Septuagint, an ancient Greek translation of the Hebrew Bible, which employs holokaustos for the Hebrew olah and makes reference to a burnt offering. ${ }^{8}$ With the exception of the USC Shoah Foundation, most major Holocaust institutions in the United States use the term "Holocaust." The historian Peter Novick offers a specific reason for this. He writes that "in the United States, the word 'Holocaust' first became firmly attached to the murder of European Jewry as a result of the [Eichmann] trial," explaining that the word 'Holocaust' 
began to be widely used during the 1960s in connection with the Nazi murder program, not as the result of a gentile plot, but as an import from Israel. [Novick notes that] large numbers of American journalists, covering the Eichmann trials, learned to use the word that Israelis had for many years chosen to translate "shoah" into English." Even though the word "holocaust" with the lower-case $h$ had existed long before World War II, meaning "destruction by fire," the journalists' choice to translate the Israelis' Hebrew, biblical term "shoah" into the now-"English" word "Holocaust" with the capital $H$ brought about the widespread use of the word Holocaust in the United States.

At around the same time that the first terms for describing the Holocaust were emerging, so was the term "genocide." Despite the existence of massacres before the time of the Holocaust, the term genocide did not exist until 1944 with the publication of Rafael Lemkin's Axis Rule in Occupied Europe, in which Lemkin coined the term "genocide," which he derives from the Greek genos (nation/people) and cide (to kill) ${ }^{10}$ and used it to describe the Nazis' carefully planned extermination of European Jewry. ${ }^{11}$ A PolishJewish lawyer who fled Poland just as war broke out there, Lemkin based his understanding of what he came to call "genocide" on his study of the slaughter of the Armenians in 1915 - an event now known as the Armenian Genocide. After the war, he worked diligently to argue for the creation of a convention regarding the prevention of genocide; he was successful in 1948 with the passing of the UN Convention on the Prevention and Punishment of the Crime of Genocide. ${ }^{12}$ The Convention was designed to be "a major pillar in the evolving framework of international humanitarian rules, [and as such] declares genocide a crime under international law. It condemns genocide, whether 
committed in time of peace or in time of war, and provides a definition of this crime."13 That definition is as follows:

In the present Convention, genocide means any of the following acts committed with intent to destroy, in whole or in part, a national, ethnical, racial or religious group, as such:

- (a) Killing members of the group;

- (b) Causing serious bodily or mental harm to members of the group;

- (c) Deliberately inflicting on the group conditions of life calculated to bring about its physical destruction in whole or in part;

- (d) Imposing measures intended to prevent births within the group;

- (e) Forcibly transferring children of the group to another group. ${ }^{14}$

The term has since been used to describe such events as the Armenian Genocide of 1915, the Cambodian Genocide of 1975, the Bosnian Genocide of 1992, the Rwandan Genocide of 1994, and the ongoing genocide in Darfur. ${ }^{15}$ Though the Holocaust was indeed a genocide, the term "genocide" is not used today to title the event. Only the terms described above are used — especially the term Holocaust — and there has been some tension over the inclusion of the term "holocaust" with a lowercase " $h$ " in common parlance. This tension arises from the notion that the word Holocaust can mean only one "unique" thing and that because of this the term should not be co-opted to talk about other events, even if the lowercase " $h$ " is used instead. The Holocaust occupies an important place in Jewish consciousness, so any move seen as relativizing or diluting its importance garners ire and consternation — even if such a "move" takes the form of a museum devoted to memorializing the Holocaust that also acknowledges other genocides. 


\section{B) The Holocaust as a Unique Event: Yehuda Bauer, Elie Wiesel, Michael Berenbaum, and Steven Katz}

\section{i. Yehuda Bauer and Elie Wiesel}

The four scholars named above all bring different perspectives to the uniqueness debate: Yehuda Bauer as an historian, Elie Wiesel as a Holocaust survivor, Michael Berenbaum as a scholar, and Steven Katz as a philosopher. Each has a response to and special consideration of the turmoil associated with the debates about uniqueness, the questions about whom to memorialize and how, and the assimilation of American Jewry about which Holocaust scholar Yehuda Bauer writes in his book Rethinking the Holocaust, an appropriately titled examination of key issues stemming from the event of the Holocaust and its ensuing ramifications. Bauer's ideology here and in his other relevant work positions him as one of the key figures in the debate over Holocaust uniqueness, and in that regard the following section of this chapter begins with an examination of his work. Given that Bauer also engages with Elie Wiesel, the engagement between the two scholars in included in this section as well.

Bauer opens the book with the question, "What Was the Holocaust?"16 This question encapsulates the discussions that swirl around the issue of Holocaust remembrance as it gains traction from the 1960s on. The struggle comes in trying to give shape to and define this monumental event in world history. Bauer asks whether the Holocaust is definable; in doing so, he is not only asking a philosophical question but also a question meant to imply that the task of definition is at work in the philosophical environment around the Holocaust. There is an attempt being made to define the Holocaust; can that be done, and is it a good idea to do so? What words should be used? 
As previously explained in this chapter, the question of what word to use has been troublesome from the very beginning. Should the events of 1939-1945 be called the Chorban, the Shoah, or the Holocaust? What about this new word, "genocide?" Bauer makes a distinction between the concept of genocide and the concept of Holocaust. He writes, "I would suggest retaining the term genocide for 'partial' murder and the term Holocaust for total destruction, ${ }^{, 17}$ articulating a difference to be used depending upon whether the goal of a given destruction is to kill every single person in that group. Bauer adds that the word "Holocaust can be used in two ways: to describe what happened to the Jews at Nazi hands and to describe what might happen to others if the Holocaust of the Jewish people becomes a precedent for similar actions." 18 The Holocaust is "unique," it seems, in that so far in world history the Jews were the first to be targeted for total and complete destruction. As Bauer explains concisely, "Genocide, then, is the planned attempt to destroy a national, ethnic, or racial group using measures like those outlined by Lemkin and the U.N. Convention, measures that accompany the selective mass murder of members of the targeted group. Holocaust is a radicalization of genocide: a planned attempt to physically annihilate every single member of a targeted ethnic, national, or racial group." ${ }^{19}$ Here Bauer emphasizes not just the notion of selectivity in genocide but also the idea that the radical, unmitigated nature of that selectivity during the Nazi era is what comprises the Holocaust and renders it unique.

Bauer also argues that having a definition for the Holocaust—at all, and in comparison to other genocides-demystifies an historical event that is frequently described as "indescribable," as "unrepresentable," and as defying language. He criticizes Holocaust survivor Elie Wiesel for presenting the Holocaust as unexplainable even though Wiesel's 
work also "explains" clearly the grim and terrible realities of concentration camp life and the aftermath of survival. According to Bauer, Wiesel's "readers see the Holocaust shrouded in irrationality and mystification and consigned to an impenetrable mistwhich they inevitably run away. He often expresses his fear that in future generations no one will remember the Holocaust - a prophecy that might be fulfilled if the mystification spread by him and many, many others wins out. ${ }^{20}$ The concern here is that if the Holocaust is seen as ultimately mystifying, as utterly other, and as indefinable, then it becomes not only distant in time from now but also distant in potential understanding. The danger of relegating the Holocaust to a position of radical other is that it could be forgotten. A definition concretizes and names the tragedy in perpetuity. Wiesel, however, does not shy away from arguing for the Holocaust's being so radically different from all other historical events; the closest he comes to articulating a comparison to it is to say in a 1990 interview with French journalist Phillipe de Saint-Cheron, "Personally I compare [the Holocaust] to something greater [than the Exodus from Egypt]: the Revelation on Mount Sinai. It was a kind of anti-revelation...in the sense that everything this Event revealed was anti-something: anti-Messiah, anti-good, anti-life. It was not simply death, but something more. ${ }^{21}$ Even this comparison takes the form of a negation in which the Holocaust is posited as being so grim and so other that it is not the opposite of life — death—but "something more," something so much worse. In a conversation with the public policy scholar Richard D. Heffner, Wiesel argues: "to compare [something] to Auschwitz is wrong. There was only one. There should never be another one...Remember, the Jew was illegal in Germany. It was the law that every Jew, any Jew, not only could, but must, be killed. That didn’t happen to any other people." ${ }^{22}$ Here 
Wiesel demonstrates the singularity of the Holocaust and his feeling that the tragedy that befell the Jewish people is uncomparable. ${ }^{23}$

His feeling that the Holocaust is incomparable does not prevent Wiesel from arguing for the importance of human rights advocacy. In his memoirs, he writes, "as for me, I believe that when human beings suffer I have no right to be elsewhere. How could I have refused to go to the place where the refugees from the Cambodian massacres were dying of hunger and disease?"24 Here Wiesel references the Cambodian genocide, which took place there between 1975 and 1979, and in the same chapter also cites his preoccupation with apartheid in South Africa, terrorism, Hiroshima, and what he calls "the excluded, the rejected, the marginalized." ${ }^{25}$ In describing these other atrocities and instances of hatred, prejudice, and racism, Wiesel does not undermine his arguments for the uniqueness of the Holocaust, but he does inherently argue that the Holocaust is far from the only instance of horrifying violence and horrifying human behavior in history. Despite his arguments for uniqueness, he feels morally bound to visit sites of conscience such as Cambodia and South Africa, and he feels morally bound to read, write, and think about the meaning of this litany of tragedies. Unique though the Holocaust may be according to Wiesel, there is no escaping the moral compulsion to empathize with and support other victims that it brings about.

In indirect response to this notion of the Holocaust enabling a certain attention to other tragedies, Bauer adds another argument in support of the uniqueness of the Holocaust in his speech to the Bundestag, the National Parliament of Germany, on January 27, 1998, 
in which he outlines several reasons why the Holocaust has captured more international attention than any other genocide. ${ }^{26}$ Bauer explains that during the Holocaust, for the first time in history, "people that were descended from three or four of a particular kind of grandparents — in this case Jewish — were condemned to death just for being born.” In addition, he states that it was not just European or Polish or German Jews who were targeted but all Jews, anywhere. The destruction of the Jews was meant to be "universal," not limited geographically, and total. Third, Bauer argues that the Nazis' motivation for targeting and killing Jews was purely ideological—as opposed to being pragmatic — and not grounded in reality. Finally, Bauer states that while the Nazis did not invent brutality or concentration camps, they brought industrialized killing to a different level than ever before. In summarizing his thoughts to his audience, he writes that:

The Holocaust has assumed the role of universal symbol for all evil because it presents the most extreme form of genocide, because it contains elements that are without precedent, because that tragedy was a Jewish one and because the Jews - although they are no better nor worse than others and their sufferings were neither greater nor lesser than those of others-represent one of the nuclei of modern civilization. ${ }^{27}$

Bauer's argument here for the Holocaust's singular role in society and its singular nature in relation to other genocides advocates for the Holocaust's being considered uniquedifferent, in certain specific and significant ways, from all other "forms" of genocides.

Bauer also argues for the uniqueness of the Holocaust in the years prior to his speech to the Bundestag. In his 1995 essay entitled "The Holocaust, Religion and Jewish 
History, ${ }^{, 28}$ Bauer writes that the Holocaust is unique because its perpetrators believed that Jews were devilish and ought to be destroyed in order to "save" the Aryan race; because its victims" only "crime" was to exercise their right to be individuals; because a racist ideology was behind it and was promoted religiously by a radically anti-Semitic intellectual elite; and because it was unprecedented. Even when the temples were destroyed or during the crusades, not all Jews were endangered. During the Holocaust, all Jews were targeted. The Holocaust was not simply one disaster in a continuum of disasters - either in Jewish history or in world history. For Bauer, it was an unprecedented, monumental atrocity with total destruction of the Jews as its goal for no reason other than that they were Jewish. If this is the case, that the singling out of one group of people for total destruction renders the Holocaust unique, then that fact can certainly be stated in Holocaust educational contexts, but it cannot be used to argue that the Holocaust is somehow thus superlative to other genocides. The very notion of a "superlative genocide" is repugnant in and of itself, but for the Holocaust to remain accessible to the public it cannot be placed on a pedestal.

\section{ii. Michael Berenbaum}

Holocaust historian Michael Berenbaum categorizes Bauer's emphasis on the Nazis' goal of total annihilation of the Jews as "locat[ing] the uniqueness of the Holocaust in the intentionality of the perpetrators" and as "emphasiz[ing] intent and ideology" over "results." 29 In other words, Berenbaum suggests that the reasoning behind the goal of complete annihilation is what makes the Holocaust unique, the idea being that the 
Holocaust is unique due to a unique degree of intentionality. As Berenbaum explains, "the Nazis were unrelenting; for twelve years the destruction of the Jewish people was a German priority" and "their annihilation was a policy of state, utilizing all facets of the government. ${ }^{\prime 30}$ Here Berenbaum is also demonstrating that the intentionality is undergirded by the fact that no other government or regime had ever commandeered all of its resources solely for the purpose of killing an entire people — even to the point of directing those resources away from its own needs and toward the endeavor of categorical annihilation. As he states so succinctly, the end result of the Nazis' pursuit of their "goal" was "six million dead, one million of them children — an entire world destroyed, a culture uprooted, and mankind left with new thresholds of inhumanity."”1 Jewish Studies scholar Shaul Magid argues that if this claim to uniqueness is abandoned, then "the Nazi genocide of six million Jews emerges as a tragedy of world-historical proportions, but it is not 'the Holocaust." ${ }^{\prime 32}$ The intention behind the arguments for uniqueness is that the event known as the Holocaust not dissolve into history, not be universalized..$^{33}$

In his work Berenbaum also documents another dimension of the uniqueness debate: as mentioned briefly above, the idea that the Holocaust is unique because of the methods used for and process of annihilation. Berenbaum explains that the Nazi "process of extermination from definition to expropriation to concentration to deportation [to] extermination" ${ }^{\prime 34}$ represents a radical departure from previous destructive norms. It is not that no other regime had ever concentrated or exterminated before; instead, it is that all of these elements were designed, planned, and implemented together and given moral 
credibility within the context of the Nazi ethos. ${ }^{35}$ These nuances and the others cited in this chapter thus far are important, for an understanding of them enables one to make historically accurate distinctions between the Holocaust and other atrocities. It is here, upon this precipice of distinction-making, ${ }^{36}$ that the debate over whether the Holocaust is unique really rests. If distinctions are not made, then space is created for universalizing the Holocaust, for comparing it to other genocides in a way that abandons accuracy and nuance in favor of smooth parallels. The Holocaust historian Deborah Lipstadt writes about this issue in a 1995 article for the New Republic; she states that presenting the Holocaust "as an occasion for teaching lessons in moral reasoning and good (American) citizenship...[and] as a generic inoculation against prejudice...elides the differences between the Holocaust and all manner of inhumanities and injustices. ${ }^{, 37}$ For those who, like Lipstadt, see universalizing the Holocaust as an unsound way to present the subject historically, intellectually, and emotionally, the practice of moral eliding serves no one well. As Lipstadt argues later in the same article, "[comparing the Holocaust to other atrocities] is not a matter of comparative pain —an utterly useless exercise—but of historical distinction. The issue is not who lost more people or a greater proportion of their society, but what was at the root of the genocidal efforts. ${ }^{, 38}$ This discussion of intention and of the roots of genocidal intention is of course a crucial component of Holocaust education, for it is important to understand not only that the Nazis wanted to kill all Jews but also what desire lay behind their intentionality. What lay behind Nazi intentionality, however, was not rational, and this point — that even irrational hatred can fuel genocide - ultimately supports not an argument for uniqueness but the opposite. Irrational and unchecked fear and hatred lie behind many of the most violent examples 
from world history, and while these elements figure prominently during the Holocaust, they do not make it unique.

\section{iii. Steven Katz}

Another strong voice in the uniqueness debate emerges in 1994 with the publication of historian Steven Katz's volume, The Holocaust in Historical Context: The Holocaust and Mass Death before the Modern Age, which "contrasted [the Holocaust] to all prior episodes of mass murder" and "defined the singularity of the Holocaust in the actualized intent of Hitler and the Nazis to exterminate the Jewish people in its entirety." ${ }^{39}$ While these two points have already been discussed above, Katz's work on the issues adds another dimension to the argument. In his chapter "On Defining Uniqueness," Katz writes:

In defending uniqueness, I am not simultaneously endorsing the injudicious claim that the Holocaust is more evil than alternative occurrences of extensive and systematic persecution, organized violence, and mass death. The character of the uniqueness that I am prepared to champion is not tied to a scale, a hierarchy, of evil...This, of course, is not to deny the compelling fact that the Sho'ah was a monumental crime, an astonishing act of cruelty - comprising millions of acts of cruelty - as great as any that has ever taken place. But in acknowledging this, I am not asserting that the Sho'ah is more evil than certain other specific events.... 40

Here Katz carefully and diligently emphasizes that in ascribing uniqueness to the Holocaust, he is in no way granting it moral superiority or engaging in the comparative quantification of evil. As Katz goes on to explain later in the chapter, ${ }^{41}$ he is trying to make the distinction that the Holocaust is unique for "phenomenological and logical 
reasons," not for moral ones. It is unique because of the particular phenomenon of Nazi ideology and Nazi methodology, not because one can say categorically that one death in one atrocity was brought about in a more evil fashion than another.

In this regard, Katz is influenced by the work of the late theologian Arthur A. Cohen in his book The Tremendum: A Theological Interpretation of the Holocaust. In this work Cohen articulates the notion that the Holocaust is a caesura, or break, in history so significant that it comprises a "tremendum," a surpassing of all that has been known before. Cohen writes that "beyond all...considerations...we must return again and again to break our head upon the tremendum of the abyss, a phenomenon without analogue, discontinuous from all that has been...." ${ }^{, 42}$ Here Cohen makes a decisive, impassioned statement regarding Holocaust uniqueness. For him, the Holocaust remains utterly apart from all else, "the death camps...severed from all normative connections to historical precedent and causality." ${ }^{43}$ Even the idea of a precedent does not apply to the Holocaust given the radical nature of its difference. The philosopher Emil Fackenheim, upon whom Katz also relies in his work, argues for this radical differentiation too. In his book To Mend the World, Fackenheim argues against viewing the Holocaust as yet another Jewish destruction. He writes, "the new Jewish crime was not an act...but birth; and with Teutonic consistency the Holocaust was engineered so as to give few...the choice of how to die, and none at all that between life and death. For Judaism, then, the Holocaust is a destruction without adequate precedent: it is new." ${ }^{, 44}$ Fackenheim's point here, that the lack of a choice of how to die or whether to die renders the Holocaust unique, is debatable, though his distinction between not having a choice of whether to die and having a choice between life and death usefully underscores the relentlessness of the Nazi 
pursuit. While it is certainly true that during the Holocaust Jews were targeted for death and that their deaths during the Holocaust were hardly a product of choice with a few exceptions in the case of resistance fighters and the righteous perhaps, it is also true that no one can really choose whether to live or die beyond the obvious scope of suicide.

Katz seems to recognize this problem with the argument too. He also says, like his peers, that intentionality is an important factor in demonstrating the uniqueness of the Holocaust, but here too he makes a distinction. Katz writes that he is not content with the partial definition of genocide including that there is an "intent to destroy," as he feels that a more "rigorous" definition is required, that "the concept of genocide applies only when there is an actualized intent, however, successfully carried out, to physically destroy an entire group." ${ }^{45}$ It is this more rigorous definition, Katz argues, that can be ascribed to the uniqueness of the Holocaust, in which the intent was to eliminate all Jews. ${ }^{46}$ In this way, Katz is arguing against Yehuda Bauer's understanding of genocide and is asking for actualization of the intent to be the determining factor in categorizing an event as a genocide and, ultimately, as unique.

Katz also relies on the work of religious studies scholars Roy and Alice Eckhardt for their balanced yet decisive arguments in support of Holocaust uniqueness. They write, "Among the reasons for the obscuring of the Holocaust and its distinctiveness is the omnipresence of human suffering and violence in our time," ${ }^{47}$ and they offer a new way of naming and understanding the notion of the Holocaust's uniqueness, what they call "unique uniqueness:" 
We may occasionally glimpse a transhistorical level for which, in English, the somewhat cumbersome expression "unique uniqueness" seems required...[because] we are met, not just with an unparalleled happening, or one that is discontinuous with other genocidal acts, but instead with a truly transcending or metahistorical event, an event that twists our journey through space-time by 180 degrees. ${ }^{48}$

Despite the awkward nature of the term "unique uniqueness," it does offer insight into the difficulty of expressing just how separate the Holocaust is from all else. Even the word "unique," with its implication of utter singularity, is not singular or radical enough to express the reversal, as the Eckhardts argue, of our human journey through time and space.

\section{iv. In Summary}

The section above chronicles the major arguments in support of the notion that the Holocaust is unique. Yehuda Bauer emphasizes the singling out of Jews for total destruction. Elie Wiesel argues that the Holocaust is an event on such a scale that it is like revelation but only in its opposite sense: anti-revelation. For Michael Berenbaum, the Holocaust is unique because of the perpetrators' intention to kill all Jews and because they rendered the annihilation as morally credible. Finally Steven Katz presents uniqueness in terms of the phenomenon of Nazi ideology and methodology yielding a unique uniqueness. While these arguments highlight the extreme nature of the Holocaust and articulate some of the most incredible aspects of the Nazi ethos, it is a stretch to argue that these extreme elements, taken individually or together, equate to a general uniqueness of the Holocaust. It is logically possible that every genocide has unique elements that differentiate it from others, thus it is logically impossible that any one 
genocide's unique aspect could somehow outweigh another's unique aspects. It is also logically impossible that the Holocaust is unique simply because if it happened once, it can happen again. The next section of this chapter lays out some of the major arguments against the uniqueness of the Holocaust and emphasizes above all else the immoral nature of the argument that the Holocaust is unique.

\section{B) Against Uniqueness}

Despite Steven Katz's arguments above that support the idea of Holocaust uniqueness, his work also refutes a number of grounds on which the Holocaust is often thought to be unique. First, Katz argues that even though he believes the Holocaust to be unique, he does think that it can be repeated, and he agrees with Yehuda Bauer's argument that if the Holocaust was possible once, it is possible again. ${ }^{49}$ Second, Katz argues that when examined from a quantitative standpoint, the Holocaust is not unique, especially when examined in terms of quantitative proportionality. When the Holocaust is compared to other Jewish atrocities, the proportion of Jews killed is indeed higher, but when examined against the scope of atrocities in world history, there are tragedies such as the Armenian genocide and the Europeans' destruction of New World communities in which an equal or greater percentage of civilians were killed. ${ }^{50}$ Third, Katz concludes that because "numbers alone will not establish the uniqueness of the Sho'ah," then it is "metaphysical conceptions" that are needed to demonstrate the uniqueness of the Holocaust. ${ }^{51}$

It is also metaphysical arguments, however, that challenge the position that the Holocaust is unique. The historian David Stannard, who is known for his book American Holocaust in which he writes about the Native American genocide, argues that "the 
defenders of uniqueness were, in effect, denying all other genocides," that "intent" is not a reasonable "factor for evaluating the qualitative character of a genocide," and that "Jews both inside and outside Israel had embraced uniqueness both for ethnocentric reasons...and...political ones. ${ }^{, 52}$ Here Stannard not only refutes the claims upon which proponents of uniqueness rely but also claims that those claims are used in culturally myopic and self-serving ways. On a similar note, Native American scholar Ward Churchill claimed that uniqueness is akin to Holocaust denial and that arguments for uniqueness are a "“systematic assault...on truth,",53 thereby dismissing claims of uniqueness as presenting the Holocaust falsely and with aggressive attention to presenting it as what it is not. In addition to these objections, Rosenfeld cites a larger problem, writing that "it is hard to escape the conclusion that the recent debate [on Holocaust uniqueness] has done little to advance our understanding of modern genocide and much to hinder it" ${ }^{54}$ and that "the emphatically politicized tone of the debate has diminished its contributions to our understanding of the Holocaust and genocide. ${ }^{.55}$ Here Rosenfeld calls attention to the way that the debate between scholars over the issue of uniqueness has resulted more in attention to the arguing than to the arguments. As he indicates, there are contributions to the field that can be gleaned from the debate, but those, it seems, are at risk of being lost.

Scholar Peter Novick responds to these concerns, writing not only about the issue of Holocaust uniqueness but also about the positive and negative effects of Holocaust remembrance and memorialization. In regard to the question of whether the Holocaust is unique, Novick—like Alvin Rosenfeld—feels that arguments for the uniqueness of the Holocaust are nothing but angry and competitive in nature, that they are devoid of 
intellectual merit, and that they have little or nothing to do with the Holocaust. ${ }^{56}$ To him, the motivations behind the discussion about Holocaust uniqueness are empty and vacuous. The discourse represents a childish competition for attention, not a scholarly exploration of history. There is a need for the Holocaust to be considered "special" for the sake of being considered special, not because of any particular concern for the actual event or even for the people who perished. There is a certain anti-intellectual desperation at work in the argument that the Holocaust is unique that is not only unattractive, offensive, and morally reprehensible in its blatant ignoring of its similarities to certain aspects of other genocides. As Novick asks succinctly, what else can all of this possibly mean except "your catastrophe, unlike ours, is ordinary; unlike ours is comprehensible; unlike ours is representable?" 57 The implication here is that these arguments are not only morally reprehensible but also disrespectful to victims of any tragedy, and while Novick does acknowledge that there are aspects of the Holocaust that are unique or "distinctive," overall he is arguing that these elements alone do not position the Holocaust over and above other traumatic events in world history. Each moment in history is arguably unique, but aside from this rational argument, there is the argument that it is reprehensible to engage in this angling for the claim to the superlative catastrophe. Novick implies that instead of strengthening the place of Holocaust history, that place is instead weakened when arguments for uniqueness are made.

The historian Alon Confino examines the debate from the angle that there is an irony in this discussion of whether the Holocaust is unique or in fact shares elements in common with other atrocities. He writes, 
it is precisely the clear articulation of commonalities that reveals the historically specific...[and] it is about finding the historically specific within a genre of historical events...We explain nothing either by treating all genocides as similar to such a degree as to deny each its historical particularity. By articulating similarities among genocides, comparative genocide studies has made clear also some of the specificities of the extermination of the Jews to its time and place. ${ }^{58}$

In order to achieve understanding, then, both the common and unique elements of genocides must be examined. As Confino also explains, "the Holocaust is not strangely unique. Rather, all pasts are strange, and the historian's task is precisely to elucidate this strangeness, not to overcome it." ${ }^{59}$ If there are differences between the Holocaust and other genocides, then those should be brought to light for the sake of historical accuracy and understanding but not solely for the purpose of capturing and isolating the atrocity.

Another way in which the argument for Holocaust uniqueness harms efforts at Holocaust remembrance is that it creates what Novick calls "Holocaust envy," a jealousy that began to appear when Jews received more attention for "their atrocity" than did other groups such as Japanese Americans, Chinese Americans, Armenian Americans, ${ }^{60}$ and AfricanAmericans to name a few. Despite the presence of these different groups' all needing and wanting their histories to be recognized, it was ultimately the Jews who were the most successful at nationally recognized memorialization. As Novick explains, “...the success of Jews in gaining permanent possession of center stage for their tragedy, and their equal success in making it the benchmark against which other atrocities were judged, produced a fair amount of resentment...."61 This resentment indicates that even if the Jewish community had good intentions in wanting to secure the memory of the Holocaust, the 
argument of uniqueness and the positing of the Holocaust as superior to all other tragedies cause the memorial effort to go awry.

There is also the ethical question that surfaces from the discussion about Holocaust uniqueness, the question of what statement the notion that the Holocaust is unique makes about the validity and significance of other cultures' traumatic pasts. Gavriel Rosenfeld cites historian David Stannard's argument that Jews' exclusive view of the Holocaust indicates their marginalization of others' sufferings, ${ }^{62}$ an argument that seems on its surface to be a serious ethical downside to the exclusivist posture. Rosenfeld refutes Stannard's claim, though, arguing that "it is faulty logic...to claim that by focusing scholarly attention on one nation's sufferings, they 'deny' the sufferings of another." Just because the Jewish community has grappled with Holocaust history through a tense, public debate about Holocaust uniqueness and through public places like museums does not mean that it intends to deny the sufferings of others, but even so the debate about uniqueness has angered other communities that have suffered.

The Armenian community has been especially vocal about its frustration with the Jewish community over the issue of uniqueness. Armenians "were offended by what they saw as Jewish insistence on making the Holocaust 'unique,' while portraying the Armenian genocide as 'ordinary." "64 In addition, Armenians were frustrated that "the designers of the Washington Holocaust Museum went back on earlier commitments to give significant space to the Armenian genocide as part of the background of the Holocaust" and that the museums had "yielded as well to the urgent lobbying of the Israeli government, which was anxious not to offend Turkey, ${ }^{, 65}$ a country that does not recognize the Armenian 
genocide. The Armenians' and other groups' protestations against the assertion of Holocaust uniqueness caused a backlash in the Jewish community—both for and against the argument of uniqueness. Arguments against the Holocaust's being understood as unique include that "the obsession with uniqueness is a "distasteful secular version of chosenness,' which introduces pointless enmity between Jews and other victims;" that "the elaborate arguments for uniqueness are 'intellectually vulgar;"” and that "insistence on...uniqueness...[proceeds] apace with the Holocaust's increasing sacralization." ${ }^{\prime 66}$ There was also the concern that within the Jewish community the Holocaust was becoming the "new" Judaism, that watching Holocaust films, reading Holocaust books, and visiting Holocaust museums had replaced traditional Jewish texts and practices as post-war assimilation increased.

In addition, despite all of his early arguments for the uniqueness of the Holocaust, however, Yehuda Bauer changed his thinking on the issues and ultimately offered the following, differing conclusion that he ultimately linked to the subject of the Armenian genocide: that the Holocaust was not unique because it happened once, so it can be repeated. In a speech at Clark University in 2009, Bauer stated that "if [the Holocaust] had been unique, we could forget about it. ${ }^{, 67}$ Here Bauer views the uniqueness of an event in relation to whether it can be relegated to the past and ultimately forgotten. As this dissertation demonstrates, the Holocaust has not been forgotten; to the contrary, even as recently as two years ago, a new Holocaust museum opened in the United States, with more to come in Europe. Part of the Holocaust's unforgettable nature, Bauer would argue, is that it was an extreme form of genocide ${ }^{68}$ so it has become the paradigmatic genocide that is used to explain and examine all other genocides. As he states at Clark, 
"If you deal with genocides, you have to deal with the Holocaust. You can never run away." Bauer now views the Holocaust as being the furthest point on a continuum that begins with mass violence, moves to genocide, and then moves beyond genocide to Holocaust. It is at this point, Bauer argues, that the word Holocaust means not only the planned extermination of all Jews but also "a generic name for an ideologically motivated planned total murder of a whole people, ${ }^{, 69}$ and he adds that the genocide of the Armenians belongs in this category.

\section{i. In Summary}

Despite Bauer's arguments that the Holocaust cannot be forgotten because it is not unique, the museological instantiation of Holocaust remembrance in cities around the world, and the continued discussion of past and present-day genocides, it is still possible to argue that the Holocaust might be forgotten. How can this be, though, if in the United States, almost every major city has-if not a Holocaust museum —a Holocaust memorial, a center for Holocaust Studies, a university that offers courses on the Holocaust, and/or Holocaust education in secondary schools? There are three major reasons to be concerned that the Holocaust might be forgotten: 1) the demise of the survivor population is imminent; 2) it is unlikely that another Holocaust museum will ever be built in the United States; and 3) American Jewish prioritization of the Holocaust is dwindling and will naturally continue to do so the further removed in time the Holocaust becomes. The debate over the uniqueness of the Holocaust perhaps has less importance now because American Jewish culture has placed the importance on how and where to memorialize the Holocaust over the importance of philosophical debate. Given the inherently alienating 
and overly aggressive nature of arguing to a non-Jewish audience that the Holocaust is unique, no Holocaust museum makes or would make this point overtly even if the museum's senior leadership does feel that the Holocaust is unique. The focus then becomes on how to instantiate Holocaust memory, ${ }^{70}$ a focus that is also far more familiar to non-Jews than the philosophical nuances of a debate on Holocaust uniqueness and to Jews because of the Jewish attention to memory historically, the subject to which this chapter now turns.

\section{It's Jewish to Remember}

Before beginning a discussion of Holocaust memory, it is important to acknowledge that the Jewish interest in memory did not arise only after the Holocaust, so the ways in which Judaism has always prioritized remembrance will be described in the following section. Holocaust museums in the United States emerged, as explained in the opening chapter of this dissertation, in part out of Jewish immigrants' need for a mode of Holocaust memorialization that was broader and more concrete than private, local, small-scale memorial efforts and also from centuries of the Jewish emphasis on remembrance, for there is a long tradition of memorialization and commemoration in Judaism, and there is therefore in Judaism a normative imperative to remember. Jewish holidays and commemorative days such as Passover and Yom HaShoah remind Jews to remember the sacrifices of their ancestors. On Yom Kippur, Jews look back over the preceding year in order to remember and make amends with those whom they have wronged. On Hanukah and Purim, the trials and triumphs of the Jewish people are recalled and celebrated. 
During the Sabbath, Jews retreat from the secular world and remember that there is a world to come.

The Jewish Biblical tradition of remembrance undergirds these holy day practices and instructs the habits of everyday Jewish life. This tradition teaches not just to remember what is good but also to think back on the most difficult times and learn from them. Biblically, remembrance also serves as a catalyst in the relationship between God and the people Israel. He wants them to remember Him, and they must learn to remember Him and His lessons. Early in the Book of Genesis when God makes his covenant with Noah, He says to Noah, "When I bring clouds over the earth, and the bow appears in the clouds, I will remember my covenant between Me and you and every living creature among all flesh, so that the waters shall never again become a flood to destroy all flesh (Gen. 9: 1415)." ${ }^{, 71}$ Here God does not simply say that when a storm is brewing, he will make sure that Noah and his people will not suffer another flood. God says that His remembering the covenant is what will prevent another flood from taking place. Remembrance serves as the hinge upon which God's promise to Noah turns; so powerful is this remembrance that it brings eternal protection to Noah. Also in the Book of Genesis, there is the paradigmatic story of Sarah's difficulty conceiving a child, which she cannot. When God "remembers" her, however, she does conceive (Gen. 21:1). Again God's remembering brings good to humankind. Remembering, it seems, is a powerful force in divine hands, but is human remembrance considered equally as powerful in the Hebrew Bible? 
The answer to this question is that yes, Judaism considers remembrance to be a powerful force in human hands as well as in divine hands. In the Hebrew Bible, the Israelites are commanded to remember. They are to "remember the Sabbath Day and keep it holy" (Ex. 20:8) and to "remember the long way that the LORD [their] God" made them travel in the wilderness in order to "learn what was in [their] hearts" (Deut. 8:2). Remembrance is the first step in keeping the Sabbath, and Moses tells the Israelites that remembrance of the long, difficult journey in the desert is how they will endure hard times in the future, when God is testing them and when they are wondering why God would force them to endure challenges when He has the capacity to remedy the problem. The Israelites can use remembrance to honor God and to understand God, but if they do not remember, they will neglect His sacred days and lack the understanding that the challenge represents a test, not an abandonment.

There are also situations in the Hebrew Bible in which the notion of remembrance is employed more subtly than in the previously cited situations. One such example can be found in the story of Cain and Abel. On one wall of the Hall of Remembrance at the United States Holocaust Memorial Museum, one finds the quotation "Then He [God] said, 'What have you [Cain] done? Hark, your brother's blood cries out to me from the ground" (Gen. 4:10). The context here is Cain's infamous slaying of his brother Abel. In the context of a Holocaust museum, the image of the blood of the dead crying out from the ground is gruesomely, horrifyingly relevant, not just because so many died during that time but also because the Nazis buried so many unceremoniously in deep pits that became massive unmarked graves. God's dialogue with Cain continues beyond the 
moment cited here on the museum's wall; he punishes Cain, who will thus henceforth be a wanderer for whom the earth shall never yield fruitful crops. Cain protests the pain of his punishment and asserts than "any man" who comes across him can kill him, but God responds by punishing Cain again, placing a "mark" on him so that no one will kill him. Here God places on Cain the burden of remembering his crime, and in this way He uses remembrance as a punishment or atonement. Remembrance, then, is not always a vehicle for good; it can also serve as a painful and unrelenting reminder of dark times. The challenge for Cain, who wanted to forget his crime, is to bear the burden of his memories and to learn just how vigorously memory keeps alive those who have gone to their graves. This notion of bearing the burden of memory is a haunting one in the context of the Holocaust Memorial Museum, where one can do little other than learn and remember.

\section{The Memory Debate}

It is against this backdrop of the traditional Jewish attention to remembrance that the post-Holocaust outpouring of national, Jewish, and scholarly interest in memory emerged, and it is to the subject of this outpouring that the chapter now turns. There had been significant scholarly interest in memory before World War II, with the work of Maurice Halbwachs, and after the war with the work of Pierre Nora, Terence Ranger, and Yosef Hayim Yerushalmi, constituting the first major body of work in the field of memory studies, ${ }^{72}$ but the field saw another branch develop in response to the "unmastered past" of the Holocaust. Holocaust scholar Gavriel Rosenfeld defines an unmastered past as "an historical legacy that has acquired an exceptional, abnormal, or otherwise unsettled status in the collective memory of a given society., ${ }^{, 3}$ In the post-war 
era, the Holocaust was just such an unmastered past in Europe and in the United States, and the new work in memory studies by scholars such as Jeffrey Olick, James Young, and Geoffrey Hartman sought to address it. As other scholars also began to contribute to the burgeoning body of work on memory, the term "memory boom" arose to describe the explosion of work in this particular area.

There are multiple reasons why memory studies exploded after the Holocaust. One reason is that the generation of the civil rights movement in the 1960 s was not afraid to confront the past, to challenge morally the decisions and actions of the preceding generation, and to demand accountability. In the 1970s and 1980s, the multicultural movements that developed were interested in securing rights for all peoples, in using memory as a way to end longstanding forms of oppression, and in favoring ecumenicism over nationalism. In addition, the previously separate fields of history and memory began to work in tandem, as the post-modernist deconstructionist impulse inspired the linking of these two elements of the past rather than emphasizing their distinctiveness. When the Cold War ended and people felt more secure about the present, they finally felt comfortable thinking about and considering the morality of the past. Finally, when the Yugoslav civil war took place in the early 1990s, the violence, intense nationalism, and photographs of emaciated prisoners were all reminiscent of the Holocaust and were understood in part in light of the Holocaust. As a result, many countries and even major institutions such as the Catholic Church participated in the memory boom as part of a widespread commitment to acknowledging their unmastered pasts. 
A special sense of urgency and importance characterized the memory work of Germany, and it developed various commemorative activities and structures such as the Jewish Museum Berlin, as described in Chapter Two. When its Memorial to the Murdered Jews of Europe opened on May 10, 2005 in Berlin, its intention was to make the statement that the Holocaust could never be considered merely a part of Germany's past; it must instead be remembered. The starkness of the memorial's aesthetic and its location in central Berlin-2,711 dark rectangular stones of varying size on a sloping plot of five-and-a-half acres of land - are thought to render nearly impossible avoidance of Germany's Nazi past. According to Gavriel Rosenfeld, however, the construction of the memorial has brought Germany's aforementioned sense of urgency to an end, as if to suggest that the necessary remembering in Germany had been completed and that the memory boom there has come to a close. Although other countries - such as Turkey in relation to the Armenian Genocide - have not yet mastered their pasts, there is the concern that they will all eventually follow the same mnemonic trajectory as Germany, that a certain moment of closure will be perceived and perhaps even desired, and that a given country or institution's interest in memory will peak and then wane.

In addition, there is the concern that for today's younger generation, there are threats that loom larger than the past. Rosenfeld cites the threats of Islamic fundamentalism, globalwarming, and nuclear arms development as being of major concern today, especially after 9/11. When considered against these threats, memorializing the past can seem like an unaffordable luxury. In the face of dire predictions about the future, and in response to Germany's memorial history, it becomes worth questioning what the fate of the memory 
boom will be, whether it will peter out or "bust" completely, whether it will land softly or crash. Rosenfeld argues that the memory boom will surely have a soft landing, as it will not evaporate but instead leave behind an infrastructure that includes extensive scholarly work, memorials, and museums that guarantee the institutionalization of memory if not a continued boom per se. The memory boom has been instructional too, as it demonstrates how to institutionalize memory and how to examine the relationship between the injustices of today and the unmastered pasts of yesterday. In light of these questions, this section of the dissertation on Holocaust memory intends to lay out the major arguments of the various strains of memory studies — both before and during the memory boomand to articulate which of those arguments remain pertinent today and in what ways.

\section{A) The First Branch of Memory Studies}

As mentioned above, before the memory boom "officially" began, the scholars who defined the field of memory studies included but were not limited to Maurice Halbwachs, Pierre Nora, Terence Ranger, and Yosef Hayim Yerushalmi-though Halbwachs wrote much earlier than the early 1980s work of Nora, Ranger, and Yerushalmi. As Gavriel Rosenfeld explains, "These early studies, which focused on the role of remembrance in the forging of national or group identity in the modern world (as well as on the alleged threat posed to 'organic' memory by modern forms of historical consciousness), constituted the first major branch of the emerging field of memory studies. This branch's studies addressed a variety of topics, but they were all generally influenced by growing concerns about the weakenings of national or group cohesion in what was increasingly being recognized as a postcolonial and postmodern era." ${ }^{, 74}$ The following analyses of the 
work of Halbwachs, Nora, Ranger, and Yerushalmi address this concern about Jewish history and Jewish memory through the lens of each thinker, each of whom offers a different perspective on the issue. Individually, each provides a new vocabulary or a new perspective on memory, and taken together, the four lay the groundwork on which later scholars, cited later in the chapter, build their equally insightful work.

\section{i. Maurice Halbwachs}

Maurice Halbwachs, a French sociologist who died in Buchenwald, is known for having developed the concept of collective memory. This theory posits memories as existing not just as individual, personal elements but as being connected to a web of other memories that are all supported by an array of structures - aesthetic, philosophical, moral, and so on-and that are all viewed in light of today. As Halbwachs explains, "there are no recollections which can be said to be purely interior, that is, which can be preserved only within individual memory. Indeed, from the moment that a recollection reproduces a collective perception, it can itself only be a collective." ${ }^{, 75}$ Memories, even personal ones, belong to the collective, not just to the individual, even though those belonging to the collective never, of course, experienced the individual's memory.

Halbwachs also makes a distinction between historical memory and autobiographical memory, arguing that historical memories can only be accessed through various forms of documentation or preserved through activities or events designed to acknowledge a particular moment in history. Autobiographical memory, on the other hand, involves a memory of something that one has experienced personally that would inevitably fade if it is not shared with others and reinforced through the group's repeated remembering of the 
event. It is these collective, group activities that cement the original memory and give it the strength to defeat the pressure of the present — the pressure that the more recent, more intensely felt experiences of today place onto memory.

The phenomemon of the group or collectivity is also what "localizes" memories for Halbwachs. He writes that "what makes recent memories hang together is not that they are contiguous in time: it is rather that they are part of a totality of thoughts common to a group...." ${ }^{76}$ A given group holds dear and holds in common a certain set of memories so that the memories become local to that group. That said, this localization also occurs across groups, for the same experience can be shared by multiple people, all of whom may belong to different groups. The memory becomes a part of all of the groups' collective memory systems, and it can only be understood by those who did not experience the memory can locate it within the context of the group. Each memory, it seems, is located within a structure or framework that provides a context within which the group remembers. Historical moments become memorial moments when operating within the framework of a given group's collective memory, where the groups perceives, processes, and locates them both inside and outside of time. The more groups there are that have a particular memory in their collective framework, the better the recollection, as "a recollection is the richer when it reappears at the junction of a greater number of these frameworks, which in effect intersect each other and overlap in part."

For a Holocaust survivor, then, memories from that time period do not simply exist in the mind of the survivor; instead, those memories are related to the memories of other 
survivors and to the collective effect of survivor testimony. In other words, one memory from the Holocaust helps to create a collective impression of the Holocaust, a collective remembrance of that time that belongs to more than the individual. Any person, years later, who participates in Holocaust remembrance through learning, through memorial activities, or through visiting a Holocaust museum — to name a few examples—-becomes part of the collective memory that surrounds the Holocaust and that absorbs and preserves the original memory. One way to apply Halbwachs' concept of collective memory to the museological practices evaluated in this dissertation is to consider that it has enabled Holocaust museums to come into being, for collective memory creates the possibility for those who did not experience a particular event to support its remembrance by remembering and to make reasonable museums' claim to necessity. Without the understanding that a collective is responsible for remembrance because individual memories are inherently connected to other memories and to other individuals, there would merely be a need for the recording of individual memories for posterity—not necessarily for the display and representation of those memories in such a place as a museum. If memory could not be transmitted from the individual to the collective, then there would also not be a way for Holocaust museums to use survivor testimony to create personal, individually communicated Holocaust memory in Jewish and non-Jewish visitors alike. Finally, without the concept of collective memory, there would not be a way to express where aggregated individual memories can abide once the individuals are gone.

\section{ii. Pierre Nora}


Twentieth-century French scholar Pierre Nora is perhaps best known for his essay "Between Memory and History: Les Lieux de Mémoire," ${ }^{, 8}$ in which he argues that there are now only "lieux de mémoire, sites of memory, because there are no longer milieu de mémoire, real environments on memory." ${ }^{, 79}$ Like his predecessor Maurice Halbwachs, Nora views memory and history as being opposed to each other, and he argues that history "eradicates" memory to such a degree that sites of memory are required if memories are to be preserved. There is no environment of memory that will inherently or automatically preserve the memories. Memory, according to Nora, "takes root in the concrete, in spaces, gestures, images, and objects," whereas "history binds itself strictly to temporal communities, to progressions and relations between things. Memory is absolute, while history can only conceive the relative." ${ }^{80}$ Written in 1984 while the United States Holocaust Memorial Museum in Washington, D.C. was still in its early planning stages, Nora's conclusion here that memory requires the concrete predicts the most tangible way that memory of the Holocaust becomes anchored in American culture: through Holocaust museums.

Holocaust museums mediate memory exactly as Nora describes, for the museums allow Holocaust memory to root itself into American culture through their very concreteness and through the "spaces, gestures, images, and objects" housed therein. This rootedness is assumed to bring about permanence, a particularly reassuring sentiment during the decades immediately after the Holocaust. Nora writes, though, that "museums" and other memorial practices such as "archives, cemeteries, festivals, anniversaries...[and] monuments" function as "the boundary stones of another age, illusions of eternity." 
Here Nora points out the dichotomous nature of the way in which Holocaust museums preserve the memory of the Holocaust. They do mark out the edges of another time and delineate for museum-goers that which might otherwise never be known in the first place or that which would be forgotten. On the other hand, they do present an "illusion of eternity" not only by giving a physical home to objects and information in a way that implies their almost-eternal preservation but also by doing the very memorial work that they are so proud to do. In other words, Holocaust museums have taken on the task of Holocaust remembrance so extensively and so well that their very success ironically permits or could permit a certain forgetfulness amongst Jews today who belong to the tertiary generation of witnesses and whore are therefore thrice-removed from the Holocaust: with many Holocaust museums located around the world, why focus on Holocaust remembrance outside the museum if inside the museum's walls, Holocaust memory has been secured? ${ }^{82}$

Nora argues that memorial institutions like museums are nostalgic enterprises that look back on the past with a chilly glance that sweeps across all museum-goers and renders them "identical and equal;" 83 to the museum, all visitors are the same. They are all engaged in the same "ritual," and they are all operating within the confines of a predetermined, deliberate, inorganic rendering of the past that threatens to take the experience of remembering out of the individual and place it onto the museum, an external memory device. His critique here of memorial institutions seems harsh, as if the experience of visiting a Holocaust museum were somewhat useless, but acknowledging the darkest, most critical light in which museums can be seen ultimately serves as a foil 
against which the opposite conclusion can be drawn. As Nora explains, if memory-in this case Holocaust memory-were not threatened, then there would not be the need for such museums. He also argues that if the memories "were to be set free they would be useless" ${ }^{\prime 4}$ and that history would "besiege" them, transforming them in ways that would make them different, unrecognizable, and meaningless. In the end, for Nora it is this "push and pull that produces lieux de mémoire," for these museums, these places of memory, enable the memories that they house to stand outside of history and outside of time, having removed themselves from being tossed about and having given them a home no matter whether the permanence of that home is illusory or not, anticipating the museum's task to convey both history and memory.

\section{iii. Terence Ranger and Eric Hobsbawm}

In The Invention of Tradition, ${ }^{85}$ a collection of essays on the relationships between, ritual, the past, and tradition edited by Terence Ranger and Eric Hobsbawm, Hobsbawn defines the concept of invented tradition as "a set of practices, normally governed by overtly or tacitly accepted rules and of a ritual or symbolic nature, which seeks to inculcate certain values and norms of behavior by repetition, which automatically implies continuity with the past. ${ }^{, 86}$ He goes on to explain that the act of inventing traditions is particularly interesting for the way in which they are responding to the ever-changing world. New traditions are both responses to the present and responses to the past, for they attempt to maintain a connection to the past and to "establish continuity" ${ }^{87}$ with the past despite being new and "invented." New traditions also share with old traditions the hope that they will inculcate a certain practice or message in the relevant community and that they 
will "structure at least some parts of social life within it as unchanging and invariant," thereby creating a sense of permanence that can serve as an anchor to culture and community.

Hobsbawm also argues that traditions are most likely to be invented in times of significant change in a society, when the transformation that is at work "weakens," "destroys," or challenges old patterns and the old traditions that surrounded those societal patterns. Traditions are invented in response to this rapid change and in response to particular needs, and just as the Holocaust constitutes one such challenge to society that caused it to find ways to respond to such a tragedy, so can Holocaust museums be considered new "traditions." As documented in the introduction to this chapter, the postHolocaust memory boom saw a surge of scholarly work on memory that drew on traditional Jewish sources, examined previous scholarly work on memory, and devoted a previously unprecedented level of attention to writing about memory. In addition, in response to the Holocaust and out of concern about Holocaust remembrance, the Jewish community in the United States built Holocaust museums, memorial identity museums devoted (primarily) not only to one particular group of people but also to one particular event in history. The decision to build Holocaust museums and education centers across the country suggests a dissatisfaction with traditional Jewish memorial practices, as mentioned; no matter how extensive these practices were or how focused on the Holocaust, there was still something missing. The community called upon the institution of the museum and invented the tradition of the Holocaust museum as inculcator of Holocaust memory in order to ensure that Holocaust remembrance would never vary, 
dissolve, or become practiced only by the Jewish community. In this sense, it is perhaps inaccurate to say that the rapid societal transformation that the Holocaust brought about "weakened" or "destroyed" traditional Jewish social patterns or practices, as there is much evidence to demonstrate how deeply the Jewish community rallied around the cause of Holocaust remembrance. The Holocaust did, however, present an enormous challenge to world Jewry on many levels, and in this sense the proliferation of Holocaust museums that began in the early 1990s demonstrates that Holocaust remembrance required a powerful, invented tradition with a degree of perceived permanence that had not yet been achieved.

The invented tradition of the Holocaust museum includes elements from all three of what Hobsbawm calls "overlapping types." ${ }^{89}$ Hobsbawm's three types include invented traditions that establish "social cohesion or...real or artificial communities," that establish "institutions," and that have as their "main purpose...the inculcation of beliefs, value systems and conventions of behavior. ${ }^{, 90}$ Holocaust museums create social cohesion and real communities of supporters within the Jewish community and within other groups such as teachers, students, and activists who support not only the cause of memorialization and remembrance but also the notion of an institution that is designed to challenge and change pre-existing knowledge, beliefs, values, and behaviors. The museums devote time and energy to education precisely because commemoration alone is not considered sufficient; an inculcation of a certain value system must be effected alongside commemoration through the combined renderings of history and memory in the museological setting. 


\section{iv. Yosef Hayim Yerushalmi}

Yerushalmi's book, Zakhor: Jewish History and Jewish Memory, ${ }^{91}$ examines Jewish history and Jewish memory from biblical times through the present day, the time of its writing in 1982 . He begins by making clear the depth of the biblical command to remember, noting that in Judaism memory is an imperative, not an option. Of this command, though, Yerushalmi asks a pivotal question, "But what were the Jews to remember, and by what means, $" 92$ for over time there have been different ways for Jews to remember. As he later explains, the rabbis saw the Bible as containing all of Jewish history, and they saw that history as having a specific purpose for the Jewish people. ${ }^{93}$ In the Middle Ages, though, Jews were meant to remember through ritual and through liturgy as a way to bring the past into the present, to bring events of Jewish history into the present day. After the Spanish Expulsion in 1492, Jewish historians began to find meaning in the notion that while events from ancient times should be remembered, so should events from recent- or present-day. In addition, past events also became seen as having value for the future, so in this sense history and memory became more fused at this time instead of being understood as separate entities as before.

A turn away from this fusion of history and memory comes later, when according to Yerushalmi, in the modern period the forces of assimilation prompt many Jews to move away from the ritual and liturgy that had previously anchored Jewish history and Jewish memory and toward a type of Jewish life that prioritizes history over memory. He even goes so far as to equate Jewish history with Jewish faith as a way to illustrate the depth to which this change has occurred, the extent to which Jewish collective memory wanes 
during this time. Yerushalmi wants the Jewish past to be read as Torah so that it becomes Tradition, for he argues that it is only in this context of the "canonical, shared, commanding consensus"94 that Jewish memory can survive. Overall, Zakhor emerges as a text that expresses grave concerns about the future of Jewish memory, as if Yerushalmi could add another line to his original question about what and by what means Jews are to remember so that it would read as, "But what were the Jews to remember, and by what means, and how should that which is remembered be secured?"

As Gavriel Rosenfeld explains, ${ }^{95}$ however, Yerushalmi’s concerns that Jewish history would triumph over Jewish memory fortunately did not materialize. Instead, though, the opposite took place: a memory "boom," the body of scholarly work on memory that had at its core a focus on the need to preserve the memory of the Holocaust. Yerushalmi did not foretell either the boom or the expansiveness of Holocaust memory, nor did he note the Holocaust more than once or the rising attention to Holocaust memory at all. It is for this reason that Rosenfeld sees Zakhor as certainly valuable but not prophetic. As Rosenfeld explains, part of what is valuable about Zakhor lies in Yerushalmi's articulation of the way in which "medieval Jews interpreted the events that befell them in typological form through the prism of preexisting historical precedents," just as after the Holocaust, Jews began to understand contemporary world events through the "traumatic paradigm of the Holocaust." 96 In addition, Yerushalmi's assessment in Zakhor that Jews tend to gravitate "toward mythic views of the past and present," this tendency unfolds after the Holocaust even though the desired understanding of the Holocaust is accurate and thorough, not mythic. 
What Yerushalmi offers that the other thinkers cited here do not is an understanding of the importance of memory in Jewish life over centuries and of the way that Jews examine the present in light of the past. Yerushalmi also emphasizes the process by which by which memory is created in Jewish life, an important perspective for evaluating the evolution of post-Holocaust memorial culture. Even though, as mentioned, the premuseological, post-Holocaust memorial practices ultimately proved insufficient to memorialize the Holocaust to the extent that the Jewish community desired, that insufficiency was only articulated through a lengthy process of memorial practice experimentation and development over several decades. These practices were rewarding and successful; their ultimate insufficiency was not a sign of a lack of integrity or creativity but instead a sign of how monumental the task of memorializing the Holocaust was, how broad a memorial audience was needed, and how deeply instantiated Jews wanted Holocaust memory to become in the United States. Yerushalmi's attention to the value of memorial process underscores the energy, vitality, and devotion to the memorial cause that lies behind the Jewish community's approach to Holocaust remembrance in the sixty-eight post-war years to date.

\section{B) The Second Branch of Memory Studies: Jeffrey Olick, James Young, and Geoffrey Hartman}

\section{i. Jeffrey Olick}

In sociologist Jeffrey Olick's work on the subject of collective memory, ${ }^{98}$ he uses as a starting point Maurice Halbwachs' understanding of this concept, which he (Halbwachs) characterizes as "plural, showing how shared memories can be effective markers of social 
differentiation." 99 Olick identifies two strains within Halbwachs' concept of collective memory, "individualist" and "collectivist" strains, and it is through analysis of these two aspects of collective memory that he posits a slightly different interpretation of the concept. Olick explains that individuals' memories such as the memories of individual Holocaust survivors are indeed part of the memories of a specific group, but they are particular to each individual and are housed within the mind of the individual. He then makes the useful distinction between "collected" and "collective memory" that individual memories are part of what Olick terms "collected" memory, a notion that "locates shared memories in individual minds and sees collective outcomes as aggregated individual processes." ${ }^{, 100}$ Collective memory acknowledges, however, that groups do delineate which individual memories become critical to that group's identity and thus become stored by that group in mnemonic structures other than the brain.

Olick uses the example of trauma to demonstrate how a singular, traumatic event can have a profound effect both on the individual and on the group. On the one hand, the psychological after-effects of a traumatic event perish with the individual who experienced them and cannot be directly inherited. On the other hand, because "there can be genuinely collective traumas," the trauma can indeed be experienced in part even by those who were not present at the original traumatic event. Collective memory acknowledges the possibility of a "ripple effect" in which a trauma such as Auschwitz "remains a trauma for the narratives of modernity and morality" and is "irreducible to individual and aggregated psychology." the trauma of the Holocaust is a trauma within the narrative of the Jewish community 
even thought not all Jews experienced the trauma. In the context of such a trauma such as the Holocaust, the problem then becomes how to manage the equally powerful and equally important forces of both the individualistic and collective as well as the needs of the individuals who feel either the immediate or the collective pull of the trauma. Olick urges using the more specific terms of "individualistic" and "collected" memory so that traumatic memory especially does not simply coagulate under the broad term "collective memory." He writes that "there is no individual memory without social experience nor is there any collective memory without individuals participating in communal life," recommends that "easy distinctions" about memory not be made. Instead, Olick states that it is crucial to understand that the recording of memories - and the memories themselves - indicate how remembering will take place, be documented, and be perceived in the future.

This issue of the relationship between individuals, the collective, the traumatic past, and the future of memorial representation is of special relevance to Holocaust remembrance. As indicated previously, after the Holocaust, memorial efforts took many different forms. As Olick writes, although World War I "created new attitudes toward the present and the past, the Holocaust is said to have produced an even more decisive crisis of representation."103 This crisis of representation has been realized in the extensive network of Holocaust museums built across the United States. Olick cites Holocaust scholar Saul Friedlander, who said that with the Holocaust, "we are dealing with an event which tests our traditional, conceptual, and representational categories, an 'event at the limits." "104 This language of crisis, of being on the brink or edge of all that has been 
known before, is also useful for describing how complex and difficult museum professionals found designing Holocaust museums to be. They were attempting to pay respect to and document the voices of survivors in addition to chronicling the terrible experiences of those who had perished while acknowledging and educating those for whom the experience of the Holocaust resides only in terms of collective memory.

The question was then, and is still today, whether to mark the Holocaust as a "decisive turning point" or to paint it as "one last and most horrible state in a development already under way—one which included recognition of the horrors of colonialism, two world wars, racism, environmental damage, etc—on the road to postmodernity." ${ }^{105}$ If the Holocaust is memorialized as "the decisive turning point," however, then-recall here the uniqueness debate - it is instilled with a certain uniqueness because of its role as a key, unparalleled moment around which world history turns. If it is remembered as one horrible state in a historical procession of horrors, then it is one event in history, a history that, at the time of the writing of this article in 1998, had not yet seen even more tragic events such as Columbine, 9/11, the war in Afghanistan, or the Syrian conflict. While it is useful to be aware that the Holocaust can be perceived in two distinct ways - as a turning point or part of a continuum—such a distinction is not useful because the distinction need not be made. It is possible for the Holocaust to be understood as a turning point in world history at the time that it occurred, but it is important to understand why other events such as the ones mentioned above can and should also be considered turning points for the changes that each have brought about in society. The fact of chemical weapons in Syria does not negate the fact of gas chambers during the 
Holocaust. Unfortunately, the reality of continued instances of violence since the Holocaust only highlight one of the key points of the post-Holocaust era: that the world did not learn from it - after even such a horrible event, there have emerged new ways to commit atrocities. The case builds, then, for inculcating in society a habit of collective memory and collective responsibility, and Holocaust museums invite this practice. Without this sense of collective memory of other groups' tragedies and without a sense of collective responsibility, then as history so clearly demonstrates, violence will remain forever inextinguishable.

\section{ii. James E. Young}

In James Young's two books on Holocaust memory and Holocaust representation, The Texture of Memory: Holocaust Memorials and Meaning (1993) and At Memory's Edge: After-Images of the Holocaust in Contemporary Art and Architecture (2000), he writes extensively about how the Holocaust is remembered in different nations through various memorial forms: monumental, museological, and artistic. In the earlier work, The Texture of Memory, Young emphasizes the plurality and diversity of Holocaust remembrance and representation, writing that every nation, every survivor, and every community has slightly different memories and myriad ways to preserve and/or represent those memories. For Young, Holocaust memory has a "complex texture-its many inconsistencies, faces, and shapes - that sustains the difficulty of our memory-work, not its easy resolution." 106 The many facets and forms of the memories, however, present a formidable challenge not only to museological, artistic, and architectural representation but also to how Holocaust memory is understood on a meta-level. 
As the early scholars of memory have demonstrated, one way to think about memory is in "collective terms," as individual memories that exist in relation to the communities and the immediate, present-day concerns that surround them. Young diverges from that notion, instead arguing that his goal is "to break down the notion of a memorial's 'collective memory' altogether" because he would rather "examine 'collected memory,' the many discrete memories that are gathered into common memorial spaces and assigned common meaning." ${ }^{107}$ In this way, the individual's ownership and experience of the original memory is preserved, and there is no false sense of "shared" memories to suggest that those who did not experience an event can somehow come to feel as though they have. The value of the memory and of the individual is preserved and respected, not devalued by being subsumed into the broader context of the memorial effort.

In addition to diverging from commonly held notions of collective memory, Young also expresses a healthy skepticism about the role of memorial institutions. He aims to heighten awareness of the consequences of relying upon memorial representations of the past, and he cites Pierre Nora's earlier argument that the less memory is experienced inside, the more one relies on memorial structures to perform the memory-work. Memorial structures run the risk of being isolated and removed from daily life, almost fencing off the memories instead of inviting engagement with them, and of only speaking to the past without reflecting on the present. Here Young issues a reminder that if a memorial merely represents the past, houses memories and information, and serves as a reminder, then it must be considered unsatisfactory. The focus should be less on the means of remembrance than on the ends and on the question of how one responds to the 
present in light of the past. What Young proposes here is certainly aligned with the choices that many Holocaust museums have made between the time that he wrote The Texture of Memory — 1993, when the United States' first two Holocaust museums opened - and now, for museums are choosing to address the problem of contemporary genocide as well as social justice concerns such as bullying. The museums seem to concur with Young's idea that Holocaust memory should serve a purpose in today's world, and they seem to support his claim that if after a visit to a Holocaust museum, one "remain[s] unchanged by the recollective act, it could be said that [one has] not remembered at all. ${ }^{108}$ Holocaust museums today assert the importance of making a change in one's life as a result of having learned about the Holocaust and having remembered it.

Despite arguing for the importance of Holocaust memory and for representational forms designed to preserve that memory, Young also cautions against that memory taking the place not only of individual memory-work but also of Judaism. As American Jews assimilated into American cultural and religious life in the decades following the war, and in the wake of the Civil Rights movement and theories about the American "melting pot," they focused more on the Holocaust than on Judaism itself. As Young explains, "in fact, without the traditional pillars of Torah, faith, and language to unify them, the majority of Jews in America have turned increasingly to the Holocaust as their vicariously shared memory." 109 For a time, he argues, remembering the Holocaust becomes American Jews' only commonality and over the next two decades, enough money is dedicated to Holocaust museums that even in 2009 and 2010 two new 
Holocaust museums are built. Young argues that as a result of the financial and other attention, Holocaust museums become community loci for education, activism, and fundraising centered around the Holocaust and nothing else, though the degree to which this occurs now, in 2013, has changed somewhat in light of the increased distance from the Holocaust inherent in the tertiary generation.

In his study of Holocaust memorials and museums around the world, At Memory's Edge, Young posits that memorialization is not a passive effort but an active one, especially now that there is the naturally increasing sense of removal from the events of the Holocaust. Building a memorial, he says, "is a deliberate act of remembrance, a strong statement that memory must be created for the next generation, not simply preserved." $" 110$ Again, memory serves a specific purpose. It is not just recorded and presented but asked to become an actor, a thing with a life of its own that is considered to be capable of promoting the cause of social justice, of invigorating the Jewish community, and of calling attention to contemporary injustices. Is this too much to ask of memory? Young references Saul Friedlander's notion of common versus deep memory as a way to demonstrate two of the effects that memory can have on the memorial efforts of a museum. For Friedlander, common memory coheres into a whole that can have a restorative effect or offer closure, while deep memory represents trauma, that which remains unresolvable. In the museum, the deep memories often surface in the form of survivor testimony, but the common memories are that with which visitors typically leave if the deep memories are not given adequate attention in the permanent exhibitions or if the visitor never hears survivor testimony. The deep memories are also connected to and 
understood in relation to the life lived before the traumatic event that becomes the deep memory, and without that context and its proper conveyance to the visitor, the deep memory and that very context may not survive. If the deep memories do not survive, then they cannot serve as actors, and only common memory would be left— to make general statements and broad conclusions that further bury the deep memories.

\section{iii. Geoffrey Hartman}

Holocaust scholar and Kindertransport survivor Geoffrey Hartman has written extensively about the Holocaust, with a special focus on the subjects of Holocaust representation, Holocaust memory, and Holocaust survivor video testimony. ${ }^{111}$ His attention to survivor video testimony stems both from personal and scholarly interest but also from his work as Co-Founder and Project Director of the Yale Fortunoff Video Archive for Holocaust Testimonies. Hartman's work on the relationship between history and memory—with "memory" in this context implying videotaped survivor testimonies - presents a unique picture of this much-discussed pair of issues that acknowledges but moves beyond some of the traditional historical arguments against testimony and oral documentation. ${ }^{112}$ These traditional arguments include that oral histories such as survivor testimonies can be inaccurate, for they rely on memory, not historical fact per se; that the quality of a testimony depends upon factors beyond control such as whether the interviewee is feeling well that day or how skilled the interviewer is; and that the survivor is either not speaking in her native language, is relying heavily on an interpreter, or is hard to understand. Hartman allows for these critiques but also 
argues that survivor testimonies are best understood for what they are: part of the performance of "the work of mourning"113 that is the legacy of the Holocaust.

Arguably, all that follows the Holocaust—every testimony recorded, every film or book created, every museum built — is part of a mourning that has no foreseeable end. Every expression of remembrance is not just a memory but also an expression of grief. Giving voice to the memories acknowledges that they exist, that they are painful, and that they can be remembered and survived. Hartman adds that "in oral testimonies... a burdened recollection asserts itself and fashions a complex relation to the rupture between the positivism of historical experience and the symbolic stores of collective memory." The testimonies, then, have a role not just as expressions of grief or as anchors of remembrance but also as mediators between history and memory. They report on more than pure historical fact, and they guard against the subsuming of individual memory into generational change and public memory. The testimonies serve as what Hartman calls "extracanonical representations" that are "suspended between history and memory, suspended also between literature and documentary." 115 Suspended outside of time, the testimonies are able to link the past to the future, and, as Hartman explains, they are such a radically different type of "text" that "they cast a shadow on all previous fiction that claims to depict human existence in extremis." ${ }^{116}$ Their aesthetic starkness- the image of a survivor's face on a screen with no embellishments but the occasional question from the interviewer, if that—is indeed like that of a written text, which is similarly spare with its black type on a white page and no other interactions except with the mind of the reader. There is no agenda to a testimony, no architectural or aesthetic or poetic choice to 
be made. The survivors are simply allowed to be witnesses and human beings, not historians or scholars or entertainers. As Hartman writes, "it is important not to sanctify witness accounts but to see them as a representational mode with a special countercinematic integrity;" 117 the recorded testimonies transcend the medium of film. They are not just recordings, but witnesses.

\section{Conclusion}

This chapter has explicated the nuances of the debate over Holocaust uniqueness and the debate over Holocaust memory, relying on the voices of key contributors to both discussions. Within the context of this dissertation, however, these nuances must be examined not only as elements of philosophical discussions but also as they are lived out—or not—in Holocaust museums. In regard to the uniqueness debate, for example, the Holocaust museums studied in this dissertation do not employ the term "unique" in their exhibitions or literature. There is no overt argument in any of the museums' narratives that the Holocaust is in any way superlative when compared to other instances of mass violence or genocide. Even in the museums' exhibitions on modern genocide, there is no direct line of comparison drawn between those genocides and the Holocaust. The presentation of materials is objective, focused on correctly transmitting historical information, and designed to acknowledge that communities other than European Jews have suffered or are suffering atrocities too.

That said, the museums do emphasize the extent to which Jews were sought out for elimination even though they are careful to point out that Jews were not the only group that the Nazis targeted. They explain that the Nazis considered Jews to be vermin and 
that Jews were dehumanized incrementally over time even though they were innocent of any crime. The museums all emphasize the extensive nature of the concentration camp network and the perpetrators' carefully planned, industrialized killing of Jews. If all of these points that the museums emphasize are part of the argument for the uniqueness of the Holocaust even though that word is never used, then does this imply that Holocaust museums support the arguments for uniqueness, or do the museums in any way make any subtle arguments against the notion that the Holocaust is unique?

The museums' exhibitions on modern genocide are the one arena in which an argument against uniqueness could be made, for these exhibitions could develop narratives of comparison are designed to demonstrate that other genocides took place before the Holocaust and — most significantly — continued after it, but they do not suggest that the Holocaust is or is not unique. That decision is left to the visitor, if the notion of uniqueness is even considered and if the act of comparison is even performed. The ethical goal of discussing other genocides has to do with historical accuracyacknowledging that there have been other genocides — and with equitability, not with arguing for uniqueness.

The other ethical ramification of the debates discussed in this chapter has to do with the fact that Holocaust remembrance has, as mentioned, a moral imperative in Jewish life, an imperative made all the more pressing after the Holocaust. The museums thus serve this imperative; they are sanctuaries for memory, repositories of memory, and sites of memory: individual, collected, and collective. They are living memorials to the Holocaust that were invented to help Jews and others remember and mourn. If Yehuda 
Bauer's comment is true that if the Holocaust were unique, then it could be forgotten, then the continued existence of Holocaust museums can arguably serve as evidence that Holocaust museums by implication assert that the Holocaust is not unique. The Jewish community has long feared the recurrence of a genocide against the Jews. If there is concern that the Holocaust could recur, then this fact alone implies that Jews perceive the Holocaust as not being "unique," as being easily repeated, and although the debate about uniqueness is arguably a philosophical one, it is also an ethical debate with ethical ramifications. That ethical ramification is that it is unethical for a museum to present the Holocaust as unique, for doing so means that the death of a Jew during the Holocaust has more meaning than the death of another, and this cannot be so.

The debate over Holocaust memory outlined in this chapter also falls into the category of the philosophical and the ethical. The following chapter focuses on selected ethical debates that have plagued Holocaust museums as they have come into existence in the post-war era, demonstrating that the question of what Holocaust remembrance should look like and how the Holocaust should be represented has plagued Holocaust museums in the past and will continue to do so in the years to come. The demise of the survivor population and the problems of ongoing genocide and resurgent anti-Semitism indicate that Holocaust memory has not seen its final challenge.

\footnotetext{
${ }^{1}$ Gavriel Rosenfeld's essay on Holocaust uniqueness ("The Politics of Uniqueness: Reflections on the Recent Polemical Turn in Holocaust and Genocide Scholarship," Holocaust and Genocide Studies, V13 N1, Spring 1999: 28) outlines the trajectory of this debate. He explains that at first the Holocaust was seen as unique because of its "incomprehensibility" but that over time, when the Holocaust began to be historicized and politicized, a "defensive" response emerged in order to protect the Holocaust from diminishment.
} 
${ }^{2}$ Rosenfeld, "Politics of Uniqueness," 30.

${ }^{3}$ Rosenfeld, "Politics of Uniqueness," 33.

${ }^{4}$ The questions mentioned here are drawn from works such as: Yehuda Bauer's Rethinking the Holocaust (New Haven and London: Yale University Press, 2001), Steven Katz's The Holocaust in Historical Context: Volume One, The Holocaust and Mass Death before the Modern Age (New York and Oxford: Oxford University Press, 1994), Alvin Novick's The Holocaust in American Life (Boston and New York: Houghton Mifflin Company, 1999), and Alan Rosenbaum's Is the Holocaust Unique?: Perspectives on Contemporary Genocide (Boulder, Colorado: Westview Press, 1996) and Israel Charny's forward therein.

${ }^{5}$ One could argue here that the USC Shoah Foundation has responded to both concerns, as it recently began to add the testimonies of Rwandan genocide survivors to its extensive collection of Holocaust survivor testimonies.

${ }^{6}$ David J. Hogan, ed., The Holocaust Chronicle: A History in Words and Pictures, (Lincolnwood, IL: Publication International, Ltd, 2003), 57.

${ }^{7}$ Hogan, Holocaust Chronicle, 57.

${ }^{8}$ Hogan, Holocaust Chronicle, 57.

9 Peter Novick, The Holocaust in American Life (Boston and New York: Houghton Mifflin Company, 1999), 135.

${ }^{10}$ Hogan, Holocaust Chronicle, 508.

${ }^{11}$ Hogan, Holocaust Chronicle, 572.

12 According to attorney John Cooper's comprehensive work on Lemkin, Raphael Lemkin and the Struggle for the Genocide Convention (New York: Palgrave Macmillan, 2008), Lemkin worked tirelessly to pass the Convention. Finally, Cooper writes, "Lemkin had seen many of his ideas triumph. Genocide, the murder of national, ethnical, racial or religious groups, became a crime under international law...but first Lemkin had to ensure that a sufficient number of states ratified the convention in order to make it an enforceable instrument. A new international campaign for ratification was opening" (172). Lemkin died in 1959 and never saw the convention's ratification.

13 "Convention on the Prevention and Punishment of the Crime of Genocide," The United Nations, accessed August 29, 2013, http://www.un.org/millennium/law/iv-1.html.

14"Convention on the Prevention and Punishment of the Crime of Genocide," Human Rights Web, accessed August 29, 2013, http://www.hrweb.org/legal/genocide.html.

15 Today additional criteria are used to predict and define genocide. Gregory H. Stanton, Genocide scholar and president of Genocide Watch - a non-profit organization designed to "predict, prevent, stop, and punish genocide and other forms of mass murder," has developed eight criteria or "stages" of genocide that assist Genocide Watch's pursuit of its goal. The stages are, in chronological order: classification, symbolization, dehumanization, organization, polarization, preparation, extermination, and denial. Stanton explains that the final stage, denial, "always follows a genocide" and is "among the surest indicators of further genocidal massacres" ("The 8 Stages of Genocide," Genocide Watch, accessed August 29, 2013, http://www.genocidewatch.org/genocide/8stagesofgenocide.html.)

${ }^{16}$ Yehuda Bauer, Rethinking the Holocaust (New Haven and London: Yale University Press, 2001), 1. 
${ }^{17}$ Bauer, Rethinking the Holocaust, 10.

${ }^{18}$ Bauer, Rethinking the Holocaust, 10.

${ }^{19}$ Bauer, Rethinking the Holocaust, 12.

${ }^{20}$ Bauer, Rethinking the Holocaust, 15.

${ }^{21}$ Elie Wiesel, Evil and Exile, eds. Elie Wiesel and Philippe de Saint-Cheron, trans. Jon Rothschild (Notre Dame and London: University of Notre Dame Press, 1990), 59.

${ }^{22}$ Wiesel, Elie, Conversations with Elie Wiesel, Elie Wiesel and Richard D. Heffner with Thomas J. Vinciguerra, ed. (New York: Schocken Books, 2001), 94.

${ }^{23}$ Wiesel is adamant about the singularity of the Holocaust in an article he wrote for the New York Times in 1989, stating passionately: "Auschwitz is something else, always something else. It is a universe outside the universe, a creation that exists parallel to creation. Auschwitz lies on the other side of life and on the other side of death. There, one lives differently, one walks differently, one dreams differently. Auschwitz represents the negation and failure of human progress; it negates the human design and casts doubts on its validity" ("Art and the Holocaust: Trivializing Memory," New York Times, June 11, 1989). Here he expresses the radically other nature of Auschwitz and draws into question the very idea of human moral progress, arguing for the uniqueness of the Holocaust given Auschwitz.

${ }^{24}$ Elie Wiesel, And the Sea Is Never Full: Memoirs, 1969-, trans. Marion Wiesel (New York, NY: Schocken Books, 1999), 90.

${ }^{25}$ Wiesel, And the Sea, 94.

26 "Address to the Bundestag," Yehuda Bauer, accessed August 29, 2013, http://mfa.gov.il/MFA/Pages/SearchResult.aspx.

27 "Address to the Bundestag," Yehuda Bauer, accessed August 29, 2013, http://mfa.gov.il/MFA/Pages/SearchResult.aspx.

28 Yehuda Bauer, "The Holocaust, Religion and Jewish History," in Judaism in a Secular Age: An Anthology of Secular Humanistic Jewish Thought, ed. Renee Kogel et al.

(Farmington Hills, MI: International Institute for Secular Humanistic Judaism, 1995), 306-311.

${ }^{29}$ Michael Berenbaum, "The Uniqueness and Universality of the Holocaust," in A Mosaic of Victims: Non-Jews Persecuted and Murdered by the Nazis, ed. Michael Berenbaum (New York and London: New York University Press, 1990), 27.

${ }^{30}$ Berenbaum, Mosaic of Victims, 32.

${ }^{31}$ Berenbaum, Mosaic of Victims, 32.

${ }^{32}$ Shaul Magid, "The Holocaust and Jewish Identity in America: Memory, the Unique, and the Universal," Jewish Social Studies: History, Culture, Society n.s. 18, no. 2 (Winter 2012): 102 .

${ }^{33}$ The Israeli philosopher Adi Ophir argues this point with a theological emphasis in his essay "On Sanctifying the Holocaust: An Anti-Theological Treatise," in Impossible Images: Contemporary Art After the Holocaust, ed. Shelley Hornstein et al. (New York and London: New York University Press, 2003), 195-204. He writes four commandments for what he calls a "new religion," or "a religious consciousness built around the Holocaust" (195): "Thou shalt have no other holocaust before the Holocaust of the Jews of Europe; Thou shalt not make unto thee any graven image or likeness; Thou shalt not take the name of the Holocaust in vain; Remember" (197). These 
commandments, a blend of the "old" and the "new," attest to Ophir's view of the uniqueness of the Holocaust, that it is different from all other atrocities, cannot be represented in any kind of likeness, should not be equated with any other catastrophe, and must never be forgotten.

${ }^{34}$ Berenbaum, Mosaic of Victims, 32.

${ }^{35}$ The Polish sociologist Zygmunt Bauman illustrates this point in his book Modernity and the Holocaust (Ithaca, New York: Cornell University Press, 1989). He writes that "history is fraught with communal and sectarian enmities," but the Holocaust is a specific "product, as it was a failure, of modern civilization," and characteristic of the modern era, "rational, planned, scientifically informed, expert, efficiently managed, co-ordinated" in a way that no other equivalent exists before or since (88-89).

${ }^{36}$ Michael Berenbaum illustrates the degree to which the subject of Holocaust uniqueness represents a precipice for Wiesel. He writes that after Auchwitz, Wiesel "stands at the brink with respect to God. He loves Him and hates Him, he fears Him and yet tries to live without Him. Common to his treatment of God, Israel, and the Holocaust is this standing on the brink. Wiesel is torn by ambivalence as he confronts the void" (The Vision of the Void: Theological Reflection on the Works of Elie Wiesel, Middletown, CT: Wesleyan University Press, 1979, 202). This void, or trememdum, or caesura, represents the chasm into which not only the events of the Holocaust fall but also all that was known before: God, the self, and certainty.

${ }^{37}$ Deborah Lipstadt, "Not Facing History," The New Republic, March 6, 1995.

${ }^{38}$ Lipstadt, "Not Facing History."

${ }^{39}$ Rosenfeld, "Politics of Uniqueness," 37.

40 Steven Katz, The Holocaust in Historical Context: The Holocaust and Mass Death before the Modern Age, Volume I (New York and Oxford: Oxford University Press, 1994) 31.

${ }^{41}$ Katz, Holocaust in Historical Context, 33.

${ }^{42}$ Arthur A. Cohen, The Tremendum: A Theological Interpretation of the Holocaust (New York, New York: Crossroad, 1988), 25.

${ }^{43}$ Cohen, Tremendum, 12.

${ }^{44}$ Emil Fackenheim, To Mend the World, in The Holocaust: Theoretical Readings, ed. Neil Levi et al. (New Brunswick, New Jersey: Rutgers University Press, 2003), 238.

${ }^{45} \mathrm{Katz}$, Holocaust in Historical Context, 128.

${ }^{46}$ In his essay "The 'Unique' Intentionality of the Holocaust" (Modern Judaism, Vol. 1, No. 2, Sep. 1981, 173), Katz uses the example of the Armenian genocide to demonstrate how the Nazis' intention to kill all Jews differs from the Turks' murder of the Armenians. Katz writes, "it was essentially nationalist politics that was at the heart of the campaign of the Young Turks. As a consequence, the anti-Armenianism of the Turks takes on a different character from the anti-Semitism of the Nazis. For example, anti-Armenianism is not expressed in the language of metaphysical evil." Turkish hatred of the Armenians, argues Katz, was grounded in national tensions and not extended to portraying them as a radical form of evil meant to be universally exterminated.

${ }^{47}$ A. Roy Eckardt with Alice Eckardt, Long Night's Journey into Day: Life and Faith After the Holocaust (Detroit, Michigan: Wayne State University Press, 1982), 41.

${ }^{48}$ Eckardt, Long Night's Journey, 44-45. 
${ }^{49}$ Katz, Holocaust in Historical Context, 54-55.

${ }^{50}$ For the information contained in this paragraph regarding quantitative proportionality, see Katz, Holocaust in Historical Context, 65-87.

${ }^{51} \mathrm{Katz}$, Holocaust in Historical Context, 97-99.

52 Rosenfeld, G., "Politics of Uniqueness," 38-40.

${ }^{53}$ Rosenfeld, G., "Politics of Uniqueness," 41.

${ }^{54}$ Rosenfeld, G., "Politics of Uniqueness," 43.

${ }^{55}$ Rosenfeld, G., "Politics of Uniqueness," 47.

${ }^{56}$ Peter Novick, The Holocaust in American Life (Boston and New York: Houghton Mifflin Company, 1999), 9.

${ }^{57}$ Novick, Holocaust in American Life, 9.

${ }^{58}$ Alon Confino, Foundational Pasts: The Holocaust as Historical Understanding (New York, New York: Cambridge University Press, 2012), 142.

${ }^{59}$ Confino, Foundational Pasts, 14.

${ }^{60}$ Novick, Holocaust in American Life, 191-192.

${ }^{61}$ Novick, Holocaust in American Life, 192.

${ }^{62}$ Rosenfeld G., "Politics of Uniqueness," 258.

${ }^{63}$ Rosenfeld G., "Politics of Uniqueness," 259.

${ }^{64}$ Novick, Holocaust in American Life, 192.

${ }^{65}$ Novick, Holocaust in American Life, 193.

${ }^{66}$ Novick, Holocaust in American Life, 198-199.

${ }^{67} \mathrm{See}$ http://www.clarku.edu/offices/mediaservices/videoarchive/playvideo.cfm?id=152 for a recording of this talk, "Holocaust and Genocide: Two Concepts or Part of Each Other?" which Bauer gave at Clark University's International Graduate Student Conference on Holocaust and Genocide Studies on April 23, 2009.

68 In Rethinking the Holocaust, Bauer argues that it is this very extremeness that makes the Holocaust unprecedented. (New Haven and London: Yale University Press, 2001, 50).

69 Yehuda Bauer, A History of the Holocaust (New York, New York: Franklin Watts, 1982), 332.

70 The scholar of Jewish liturgy Rabbi Dalia Marx writes that since the Shoah, "for the first time in two millennia of Jewish history, commemorations of a Jewish tragedy are taking place mainly outside the walls of the synagogue. In understanding Holocaust memorialization, we encounter a long-term trend that may be nothing less than a paradigm change in Jewish consciousness," ("Memorializing the Shoah," in May God Remember: Memory and Memorializing in Judaism, ed. Rabbi Lawrence A Hoffman, Woodstock, Vermont: Jewish Lights Publishing, 2013, 61). These forms of commemorations include visits to concentration camps, Holocaust Remembrance Day ceremonies at schools and cemeteries, and monuments and museums. One of the most significant parts of what Marx calls a paradigm change, however, has to do with how Holocaust memory will be instantiated in the future, once the survivors are gone and now that the United States has, mostly likely, seen its last new Holocaust museum. What will happen once the Jewish community is left with museums, monuments, literature, films, recorded testimonies, and a vast, unpredictable future into which Holocaust memory could dissipate? There is no way to know how closely the Jewish community will hold 
Holocaust memory outside of the museums, even if the museums themselves prove capable of maintaing the memories for the duration.

${ }^{71}$ All biblical citations taken from Tanakh: The Holy Scriptures (Philadelphia and Jerusalem: The Jewish Publication Society), 1985.

${ }^{72}$ Gavriel D. Rosenfeld's article "A Looming Crash or a Soft Landing? Forecasting the Future of the Memory 'Industry,'” (Fairfield University History Faculty Publication, Chicago: Chicago University Press, 2009: 122-158), provides an extensive analysis of the trajectory of memory studies described in this discussion.

73 Rosenfeld, G., "Looming Crash," 126-127.

${ }^{74}$ Rosenfeld, G., "Looming Crash," 139.

${ }^{75}$ Lewis A. Coser, ed., Maurice Halbwachs: On Collective Memory (Chicago and London: The University of Chicago Press, 1992), 169.

${ }^{76}$ Coser, Maurice Halbwachs, 52.

${ }^{77}$ Coser, Maurice Halbwachs, 172.

${ }^{78}$ Michael Rossington and Anne Whitehead, Theories of Memory: A Reader (Baltimore: Johns Hopkins University Press, 2007).

${ }^{79}$ Rossington, Theories, 144.

${ }^{80}$ Rossington, Theories, 146.

${ }^{81}$ Rossington, Theories, 149.

${ }^{82}$ In the introduction to his book, The Texture of Memory: Holocaust Memorials and Meaning (New Haven and London: Yale University Press, 1993), James Young writes that "perhaps the more memory comes to rest in its exteriorized forms, the less it is experienced internally...for once we assign monumental form to memory, we have to some degree divested ourselves of the obligation to remember" (5). It is indeed a question of degree: does the museum take on the task of memorialization to such an extent that it safeguards Holocaust memory and removes that responsibility from the public? To a degree, yes.

${ }^{83}$ Rossington, Theories, 149.

${ }^{84}$ Rossington, Theories, 149.

${ }^{85}$ Eric Hobsbawm and Terence Ranger, The Invention of Tradition (Cambridge: Cambridge University Press, 1983).

${ }^{86}$ Hobsbawm, Invention, 1.

${ }^{87}$ Hobsbawm, Invention, 1.

${ }^{88}$ Hobsbawm, Invention, 2.

${ }^{89}$ Hobsbawm, Invention, 9.

${ }^{90}$ Hobsbawm, Invention, 9.

${ }^{91}$ Yosef Hayim Yerushalmi, Zakhor: Jewish History and Jewish Memory (Seattle and London: University of Washington Press, 1982).

92 Yerushalmi, Zakhor, 5.

93 Yerushalmi, Zakhor, 18-21.

${ }^{94}$ Yerushalmi, Zakhor, 113.

${ }^{95}$ Gavriel D. Rosenfeld, "A Flawed Prophecy? Zakhor, the Memory Boom, and the Holocaust," Jewish Quarterly Review, Volume 97, Number 4, (Fall 2007): 508-520.

${ }^{96}$ Rosenfeld, G., "Flawed Prophecy," 515.

${ }^{97}$ Rosenfeld, G., "Flawed Prophecy," 517. 
98 See especially his essay with Joyce Robbins, "Social Memory Studies: From 'Collective Memory' to the Historical Sociology of Mnemonic Practices," Annual Review of Sociology, Vol. 24 (1998): 105-140, and The Collective Memory Reader, co-edited with Vered Vinitzky-Seroussi and Daniel Levy, Oxford: Oxford University Press, 2011. 99 Olick, "Collective Memory: The Two Cultures," 334.

${ }^{100}$ Olick, "Collective Memory: The Two Cultures," 339-340.

101 Olick, "Collective Memory: The Two Cultures," 344-345.

102 Olick, "Collective Memory: The Two Cultures," 346.

103 Jeffrey Olick and Joyce Robbins, "Social Memory Studies: From 'Collective Memory' to the Historical Sociology of Mnemonic Practices," Annual Review of Sociology, Vol. 24 (1998): 119.

${ }^{104}$ Olick, "Social Memory Studies," 119.

105 Olick, "Social Memory Studies," 119.

106 Young, Texture of Memory, xi.

${ }^{107}$ Young, Texture of Memory, xi-xii.

108 Young, Texture of Memory, 15.

${ }^{109}$ Young, Texture of Memory, 348.

${ }^{110}$ Young, At Memory's Edge, 199.

${ }^{111}$ See his book The Longest Shadow: In the Aftermath of the Holocaust, New York: Palgrave Macmillan, 1996, and his collection of essays, Holocaust Remembrance: The Shapes of Memory, Oxford and Cambridge: Basil Blackwell Ltd, 1994.

${ }^{112}$ In her article on Hartman, Jewish Studies scholar Vivian Liska writes that "while admitting the limitations and insufficiencies of speech to do justice to the horror of the events [of the Holocaust], [Hartman] nevertheless encourages the recovery of individual voices and the recording of concrete particulars of the survivor's specific experiences," ("Winged Words and Wounded Voices: Geoffrey Hartman on Midrash and Testimony," Jewish Quarterly Review, Spring 2013: 135.)

${ }^{113}$ Hartman, Longest Shadow, 79.

${ }^{114}$ Hartman, Longest Shadow, 110.

${ }^{115}$ Hartman, Longest Shadow, 122.

${ }^{116}$ Hartman, Longest Shadow, 123.

${ }^{117}$ Hartman, Longest Shadow, 139. 


\section{CHAPTER FIVE: ENGAGING THE ETHICAL AND THE AESTHETIC}

The previous chapter focused on two debates that emerged after the Holocaust: the debate over whether the Holocaust can be considered unique and the debate over how best to memorialize the Holocaust. As the chapter concludes, the uniqueness debate has not had a major impact on United States Holocaust museums, but the echoes of the memory debate can still be heard today in Holocaust museums. In fact, the creation of Holocaust museums brought a new, sharp, tangible focus to this debate on how best to memorialize the Holocaust, as museum planners confronted the ethical task of memorializing the Holocaust not through books or films but through the combination of aesthetics, narrative, and objects. This chapter examines debates that have taken place over specific ethical issues or ethically contentious artifacts as Holocaust museums in the United States have been created. Special attention is given to the Holocaust Memorial Museum because the arguments had and the decisions made during its years of planning set a precedent for the ethic of display used in other Holocaust museum thereafter. The purpose of this chapter is thus threefold: 1) to provide a sense of the ethical tasks that Holocaust museums face; 2) to focus on the particular ethical issues that the Holocaust Memorial Museum confronted in its development process in order to demonstrate the ways in which it set a precedent for future Holocaust museum practices; and 3) to explain how museums are addressing two areas of special ethical concern for present-day Holocaust museums: the loss of the survivor population and the problem of resurgent anti-Semitism. 
Both of these issues represent significant challenges for the museums. First, although most Holocaust museums already incorporate recorded survivor testimonies in their exhibitions, they rely heavily on the survivors' live presence in the building, as museum tour guides, as speakers, as volunteers, as donors, as board members, and as museum members. Visitors have come to expect to see and hear a survivor when they visit a Holocaust museum, so the loss of the survivor community not only means a loss of firsthand witnesses to the event but also a loss of a group of people that has supported and nourished the museums in every aspect and provided an irreplaceable experience for visitors. Second, at the same time that this loss of the survivor population is taking place, there has been in Europe and the Middle East a resurgent anti-Semitism that has caused deep concern and debate amongst Jews worldwide. Given that Holocaust museums document in detail Nazi-era European anti-Semitism and the long history of antiSemitism before that time, the way that the museums today are confronting the resurgence of this phenomenon bears examination. Both the museums' reactions to the resurgence of anti-Semitism and the loss of the survivors speak to the role that Holocaust museums will play in American society in the years to come.

\section{The Ethical Tasks of Holocaust Museums}

One of the most significant tasks that all Holocaust museums face is how to bring about moral change in the visitor. The museums want visitors to acquire knowledge about the Holocaust, but more importantly they want to instill in museum-goers not just information but also the desire to become more committed to such noble actions as repairing the world, to preventing genocide, and to being upstanders in their 
communities — a tall order indeed. ${ }^{1}$ After visiting a Holocaust museum, the idea is that one should understand not only that there is a "legal and moral culture of rights and obligations largely structured around the notion that one should refrain from harming others" but also that "helping or not helping them is [not simply] a matter of individual inclination" and "is plainly inadequate." 2 Above and beyond the desire to educate visitors about the Holocaust, Holocaust museums are concerned with restructuring visitors' understandings of the degree to which human beings are responsible to one another and responsible for each other's safety and well-being; the museums want to produce good citizens.

As a result of this commitment, of the twelve major Holocaust museums in the United States only the Los Angeles Museum of the Holocaust does not reference a broader ethical and socio-cultural context in its mission statement, "Los Angeles Museum of the Holocaust has a two-fold mission that has remained constant since its inception in 1961: commemoration and education,", which mentions Holocaust "education and commemoration" but does not express a commitment to human rights, genocide prevention, and the condemnation of prejudice and racism as its peer museums do (see below). The museum's President and Acting Executive Director, E. Randol Schoenberg, explains the museum's choice succinctly: “Our primary responsibility is educating people about the Holocaust and commemorating the victims."4 Other Holocaust museumsranging from the Holocaust Memorial Museum and the Illinois Holocaust Museum \& Education Center to the Breman Museum in Atlanta, the Holocaust Museum Houston, and the Florida Holocaust Museum in St. Petersburg - employ the notions of personal 
responsibility for one's actions, proper ethical conduct, and democracy in their mission statements. Examples of three museums' mission statements are as follows, with keywords that represent this broad language in italics: ${ }^{5}$

From the Holocaust Memorial Museum: “The Museum's primary mission is to advance and disseminate knowledge about this unprecedented tragedy; to preserve the memory of those who suffered; and to encourage its visitors to reflect upon the moral and spiritual questions raised by the events of the Holocaust as well as their own responsibilities as citizens of a democracy."

From the Illinois museum: "The Illinois Holocaust Museum \& Education Center is dedicated to preserving the legacy of the Holocaust by honoring the memories of those who were lost and by teaching universal lessons that combat hatred, prejudice and indifference. The museum fulfills its mission through the exhibition, preservation and interpretation of its collections and through education programs and initiatives that foster the promotion of human rights and the elimination of genocide."

From the Holocaust Museum Houston: Holocaust Museum Houston is dedicated to educating people about the Holocaust, remembering the 6 million Jews and other innocent victims and honoring the survivors' legacy. Using the lessons of the Holocaust and other genocides, we teach the dangers of hatred, prejudice and apathy. ${ }^{8}$

These are but three examples, but the pattern is clear. All of these mission statements employ universalist motifs that link the Holocaust to concepts of good citizenship, the dangers of prejudice, and the importance of supporting human rights. It could be argued, then, that Holocaust museums in the United States have not swung more toward the end of the spectrum that argues for the uniqueness of the Holocaust, but to the other- the alternative but also extreme position of universalizing the Holocaust. As Holocaust scholar Alvin Rosenfeld asserts, "the imperative to reorient Holocaust [institutions] in this way is but one more illustration of a growing impatience with the place of the 
Holocaust in American life, which mirrors similar, even more strongly expressed, feelings of dissatisfaction with Holocaust history and memory in parts of Europe and

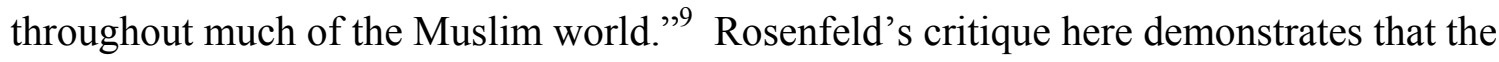
museums' broad mission statements may seem inclusive and even noble on the surface, but they can also be read as being symptomatic of a discomfort with the Holocaust. This discomfort would be in sharp contrast to the overwhelming attention that the Holocaust has received historically in the United States, as documented in earlier chapters.

Rosenfeld does not comment here only on receptivity to Holocaust history and memory in the United States, however. He alludes to the ongoing tension between Jews and Muslims in Europe and in the Arab world and to the fear that universal language in Holocaust museums can only lead not to creating moral change in the visitor but to a diluted understanding of the Holocaust. The objection here is that if the Holocaust must always be paired with universal themes, then the implication is that it cannot be understood and examined in and of itself, that it is meaningless without comparison and contextualization. Regardless of whether the Holocaust is considered "unique" or not, it can and should be examined as a discrete event in world history with a specific chronology and historiography of its own.

\section{Creating a Moral Museum}

James Ingo Freed, the architect of the Holocaust Memorial Museum and until 2005 a

partner of I. M. Pei and Partners, Architects in New York City, ${ }^{10}$ writes about its planning stages, he "says that he wants [the Holocaust Memorial Museum] to engage visitors 'not 
only intellectually, but also viscerally." "11 Peter Mostow elaborates on Freed's notion of the viscerally experienced museum when he writes that:

As with much art, the idea is to impact not just the mind, but also the senses. Perhaps one reason is that memorials aim not so much to convey an abstract intellectual message, as to awaken and expand the visitor's faculty of empathy. The aim not just to help us remember, but also to relive-to identify with the past on a personal, "visceral" level. ${ }^{12}$

Mostow's characterization of a visceral experience posits remembrance and empathy as two of the goals that the designers of this visceral experience wish to invoke or create. He is correct here, but when he adds to this picture the idea that remembrance involves "reliving" the past and "identifying with it," he implies that the experience of a Holocaust museum and the experience of a visceral reaction to such a museum are simulative. It is too much to ask of a museum that it re-create the entire experience of the Holocaust for a visitor, and it would be morally reprehensible — not to mention horrifying and impossible - for a museum to do so or to come even close. To invoke "reliving" the Holocaust as the paradigm or hallmark of a Holocaust museum experience is to violate a deeply engraved code of respect for Holocaust survivors, many of whom suffer daily from this very "reliving," and for those who died, whose lives can never be "re-lived" or with whose ends cannot and should not be "identified." Mostow's sense is correct that in a Holocaust museum, more must be awakened in the visitor than the mind, but the visceral nature of the experience is linked to a moral change in the visitor, not to a reliving. 
Mostow does acknowledge, however, that any kind of memorial "has a moral or valuerelated component." ${ }^{13}$ He explains that there are "two ways memorials also have direct effects on individual moral agents. The first concerns the roles of emotion, empathy, and imagination in moral behavior...[and] the second way...is by changing, for the individual visitor, the cultural-symbolic context in which he or she interprets future moral situations." 14 Here the "individual moral agent" is the visitor to the museum, who, it is assumed, knows little or nothing about the Holocaust in most cases, or whose previous understanding of or intimacy with the material will be underscored and strengthened during her visit to the museum. Mostow rightly identifies a connection between emotion, empathy, imagination, and moral behavior in that it is certainly possible for a person to change her moral behavior or renew her convictions after the museum prompts her to imagine another kind of life at another time, to have emotions about that which she imagines, and to have empathy for not only those who suffered but for those who could suffer or who are suffering.

One challenge to Mostow's correlation here is that, as the literary theorist Ernst van Alphen posits, "in the case of the memory of the Holocaust, imaginative representations are considered not only less effective, but even objectionable, ${ }^{, 15}$ the very idea of imagination in the context of the Holocaust is ethically fraught. Van Alphen writes about the problem of Holocaust literature and art—and architecture and personal experience can be added to this list—yielding "aesthetic pleasure" to the viewer-reader-visitor when the experience of interacting with Holocaust materials should be "barbarous" and should emphasize the facts of that barbarity. ${ }^{16}$ Therefore, there is the idea that a change in 
mindset that can occur after a visit to the museum must not be linked to an imaginary world, only to the world of facts, if it is to be linked ultimately to moral change. If the imagination in question is used as a conduit for empathy and understanding, then it need not be rejected. It is Mostow's second idea above, that memorials can change the "cultural-symbolic context in which he or she interprets future moral situations," that relies on the idea that what is new, what the visitor learns and in part imagines, will remain embedded and will not fade in the months after the museum-goer's visit. If all that the museum accomplishes is creating emotion and empathy or inviting consideration, then it has not guaranteed moral change in the moral agent—it has merely awakened certain sensibilities for as long as they linger. Depending on the disposition of the museum-goer, the awakened emotions and empathy and the habit of consideration could linger for years, or it could dissolve the minute the visitor returns to her everyday life. If the visitor's context - the way that she sees the world — has been changed, then there is greater hope that she might "interpret future moral situations" in new and better ways. The question is, then, how a museum secures a new cultural-symbolic context in the visitor other than viscerally, for as this discussion demonstrates, connecting moral change to feelings remains unreliable at best.

If the museum is successful, though, at securing a new context in which a visitor can evaluate her life and the world around her, then how does the museum expect that this visitor will effect change, and on what level? As demonstrated above, there is the expectation of intra-personal moral change and the expectation that that level of change will have an enduring, far-reaching effect in the museum-goer's life now that she has 
toured the museum. Exhibits on the righteous gentiles, non-Jews who assisted Jews evading the Nazis, serve as one specific example of how Holocaust museums intend to use factual knowledge presented in exhibitions to bring about moral change. ${ }^{17}$ The museum wants the examples of the righteous to show visitors, especially non-Jewish visitors, that they need not, in fact should not, stand by while crimes against the innocent are being perpetrated. The inherent tension in any exhibit on this subject, however, is the tension between wanting to honor the righteous and explain the good that they did without portraying their deeds in way that seems to outweigh or relativize what the Nazis did. Museums typically use the examples of Catholic priests and nuns who hid Jewish children in Catholic orphanages, of Danish citizens who ferried Jews to safety in Switzerland, and Irena Sendler, who helped organized a network of volunteers to help 2,500 escape from the Warsaw Ghetto. Oskar Schindler, a German factory-owner who saved more than 1000 Jews by employing them during the war, is perhaps the bestknown example of the righteous gentile today thanks to Steven Spielberg's 1993 film, Schindler's List, which tells the story of Schindler and his factory.

By telling the stories of these righteous people, Holocaust museums can not only honor those who saved Jews but also make an essential point about the Holocaust that still relates to today's world: that one must "stand up" when wrong is being done. Museums use the word "bystander" to describe the thousands of Germans and others who simply did nothing to oppose the Nazis, to help Jews, or to speak out when they saw crimes being committed before their eyes. Museums then use the term "upstander" to describe what the righteous people were and what we should do today. The examples given above 
of the righteous people are meant to demonstrate that even in the most difficult circumstances, one can still find a way to help those in need. As psychologists John Sabini and Maury Silver conclude in their chapter, "On Destroying the Innocent With a Clear Conscience: A Sociopsychology of the Holocaust," "our appreciation of how hard it is to do right when fate and circumstances conspire to trick us cannot obscure the fact that the measure of human nature is our capacity to do what is right and resist what is wrong."18 The museums' goal is to highlight the dangers of moral indifference and to teach visitors to conceive of themselves as compassionate, just, rational, independent people who make decisions not selfishly but with a conscious effort against immoral ideology. ${ }^{19}$ A byproduct of these goals is that visits to the museums, and especially to the internationally renown Holocaust Memorial Museum, carry an "obligatory status"not in response to a divine commandment whose source is God but to a moral imperative whose source is memory - to make what is arguably a modern-day Jewish pilgrimage. ${ }^{20}$

\section{Ethical Dilemmas at the United States Holocaust Memorial Museum:}

\section{A) The Problem of Location}

One of the first issues that plagued the planning Commission for the Holocaust Memorial Museum was that of location, for prior to its opening in 1993, "critics voiced concerns about the appropriateness of locating a museum of European mass genocide within the Washington Mall, a space of national pedagogy devoted to celebrating the history and achievements of the U.S. nation-state." 21 The concern voiced here is not just about the tension over whether a museum with primarily "European" content belongs in a part of the United States so committed to celebrating its own history. There is also the question of whether it is possible to integrate a European event into the fabric of such a national, 
American space without diluting the integrity of the original event, of the Holocaust. As the historian Omer Bartov explains, the museum's location in the capital of the United States is "highly symbolic," but it has the "potential of universalizing the Holocaust as a phenomenon of major significance for human civilization as a whole. [On the other hand,] the location also ensures that the museum will be visited by very large numbers of people." 22 The fear that Bartov expresses here is that situating the museum in a location with national appeal and in the midst of a network of memorials meant to be meaningful to all Americans will cause it to be subsumed into the culture of the city rather than prioritizing its distinctive Jewish identity, historiographical goals, and Holocaustmemorial role.

James Ingo Freed speaks to the issue of the museum's controversial location in an interview with him from the winter of 1988-89. In the interview James Ingo Freed posits that the Holocaust Memorial Museum is "one of the three most controversial monuments ever to be proposed [in Washington]," with the other two being the FDR monument and the Vietnam Memorial. ${ }^{23}$ It is not just the geographical location of the then-proposed museum that ignites Freed's passion here but also its emotional location in Washington, its non-"sentimental" 24 nature, and the potential effect of this dichotomy on its future success. There were concerns about whether people would actually go to a museum constructed in memory of Jews and of a terrible series of events in world history, none of which took place in the United States and whether visitors happily vacationing in the nation's capital with their children want to see such a museum. ${ }^{25}$ There was also the question of whether the more celebratory, patriotic atmosphere of the Mall would 
swallow up, reduce, and insult the very memory that the museum would be trying so hard to preserve.

Other Holocaust museums, such as the ones discussed in this dissertation, have not had to suffer such tense discussions about their locations-though there were certainly still concerns. When the Illinois museum was being planned, the question became whether to locate the museum in Skokie — where many survivors had settled after the war and still live and where the neo-Nazi march that sparked the creation of the museum's earliest iteration had taken place — or in Chicago's Grant Park, where the city's most famous museums are all located. Being in Skokie would mean proximity to the survivor community and an ingrained sense of history, but Skokie's being a full hour north of Chicago would mean that a museum there would be out of the way for tourists to the city, especially given that it would be inaccessible by public transportation. If the museum were in Chicago, it would be easily accessible to visitors, and it would have the potential to become part of Chicago's urban, museological lansdscape along its coastline. The museum's Director of Special Projects, Lillian Polus Gerstner, who has worked at the museum dating from when it was a small storefront museum in Skokie, wrote on this subject:

Skokie was always the number one choice of location among the founding fathers (and mothers), the survivors who began the Holocaust Memorial Foundation of Illinois. For them Skokie represented the home they had built, where they lived the American dream and raised their families. It was also the site of the attempted neo-Nazi March against which community and education triumphed. Among the new lay leadership whose involvement began with the effort to create a new, state-of-the-art museum and education center, there were many who maintained that being located in Chicago would provide greater visibility, prominence and 
prestige. The problem there was the lack of available property in a good location, and Mayor Daley, while supportive of our efforts, wasn't prepared to donate prime real estate. A few other locations were considered, including other northern suburbs, but Skokie was the best fit. In its favor, in addition to the history of the survivors, was its relatively central location - accessible for both Chicago Public Schools and suburban schools. ${ }^{26}$

Ultimately, museum officials chose to build the museum in Skokie, prioritizing the survivors, access to students, and the presence of local support over visibility, expensive land, and distance from the survivor community.

Like the Illinois museum, the Los Angeles Holocaust museum did not suffer such public contentiousness over its choice of location as did the Holocaust Memorial Museum. The only arguable stumbling block that the museum encountered regarding its location was a request from the Los Angeles City Council that the museum not be open on Saturdays and that an agreement to that effect be written into the museum's fifty-year lease from the city. City officials were afraid that crowds drawn to the museum on Saturdays would place too much stress on the already-crowded parking structure built for the Grove, with which the museum shares parking privileges during the other days of the week. As of July 2011, the City Council agreed to an amendment in the museum's lease that would permit it to be open on Saturdays. The museum had initially agreed to close on Saturdays out of respect for the Jewish Sabbath, which extends from Friday evening to Saturday evening, but it soon decided that closing on Saturdays meant losing access to the most popular day for the public to visit museums. It compromised on its original intention to observe the Sabbath by not asking Jewish staff members to work on Saturdays; the 
museum is also free, so there are no monetary transactions, the presence of which would violate the laws of the Sabbath. Since July 16, 2011, the Los Angeles museum has been open on Saturdays. ${ }^{27}$

\section{B) The Aesthetics of the Museum}

James Ingo Freed writes about the issue of how to create an ethical museum aesthetic for the Holocaust Memorial Museum when he discusses another major issue that those involved in the planning debated: the issue of "potency." ${ }^{28}$ In addition to the problem of whether a "horrifying" museum would even attract visitors, there is the question of about what level of concentration - to borrow a scientific term - to present the information so that the museum is compelling. In other words, how potent should the content of the museum be? Freed writes quite personally about his experience with hearing what emerged as two sides to this debate:

So what you have are some who believe that their historic obligation is to memorialize, and others who say that this building should not deal with lack of perception but with some more positive, upbeat thing that anyone can understand. There was always the unadmitted drive to neutralize, to make it less potent. They would like things to be more heroic, with more marble, more central spaces. I can't deal with this. I have to make a building that allows for horror, sadness. ${ }^{29}$

In Freed's statement here one can feel the aesthetic pull of the trope of the celebratory, "heroic," marbleized museum on the planning process for the Holocaust Memorial Museum, but beneath that aesthetic pull lies a stronger, more haunting current-a current that seeks to drag below the surface the grim and terrible reality of the Holocaust. Freed resists this current, bringing horror and sadness forward as the primary emotional actors 
in the aesthetic experience of the museum — not neutrality or beauty. As he explains, "There is a profound risk of aestheticization with this particular subject, of leaching out the raw power." ${ }^{, 30}$ Freed's unwillingness to abandon the "raw power" of the Holocaust informed not only the architectural decisions that he made while building the museum but also, arguably, the future of Holocaust museum architecture. In designing the Holocaust Memorial Museum the way that he did, Freed set a tone for the future of Holocaust museums and in so doing made a value statement about how the Holocaust is to be approached architecturally in American society and even internationally. ${ }^{31}$

Freed's ethic of $d e$-aestheticization makes an important connection to a key component of Holocaust history: the German "habit" of euphemizing and of finding ways to hide or disguise the truth of German operations during World War II. Freed, then, did not want to "neutralize" the "raw power" of the Holocaust architecturally because he wanted to preserve the integrity of a horrifying event, but he also did not want to reflect German architectural or moral sensibilities in his work or in the museum. It would be unthinkable to laud or model German architectural motifs in a Holocaust museum, and the thenevolving understanding of museum ethics included a sensitivity to the problem of exact reproduction. Freed did not want the Holocaust Memorial Museum to become another way to hide the truth from the American public by using "methodologies of construction" $^{32}$ that reinvigorated the German aesthetic of disguise, nor did he want to go as far as to recreate a gas chamber or the exact architectural appearance and proportions of a given concentration camp. Freed put his intentions into practice by relying on 
abstract symbolism rather than reconstructing the exact shapes and forms used in Holocaust-era structures. ${ }^{33}$

\section{C) The Problem of Representation}

Inside of Freed's symbolic and abstract building, however, are meant to be an instructive narrative and exhibitions that represent the Holocaust - a museum, one that "is principally didactic in intent, providing information and descriptions of the diverse events, primarily from 1933 to 1945 , that constituted the Holocaust. $" 34$ Visitors are meant to learn about the Holocaust from the museum through architectural, narrative, filmic, and artifact-based modes of representation. None of these forms can be the Holocaust, so instead they represent the Holocaust. The question then becomes about how literally representation should be effected, and whether representation is even an ethically acceptable means of remembrance. ${ }^{35}$ How close can Holocaust representation get to the actual Holocaust, and how close should it get? Holocaust scholar Berel Lang posits that the opposite of representation is not the abstract but the literal, or "the object as it is before or apart from being re-presented."36 Here representation can mean that an object, such as a yellow star of David badge, can represent facts and themes from the Holocaust. The badge can represent the fact that the Nazi regime forced Jews to wear it as a way to identify them quickly as Jews, and it can be more broadly representative of Nazi persecution, prejudice, and anti-Jewish legislation. In Holocaust museums, representations that are more literal, such as a re-casting of a tombstone, must be carefully documented as such in order to avoid accusations of "fabrication" that stem from the practice of Holocaust denial. Similarly, Holocaust museum architecture can hint 
at or allude to architectural features of Holocaust-era structures, but recreating them would challenge what Lang calls "the limits of representation." At the Holocaust Memorial Museum, the notion that there are limits to what can be ethically represented informed the decision to place graphic images behind chest-high barriers so that visitors could decide whether to view them or not. In a similar vein, there is no replica of a gas chamber at the museum even though gas chambers are discussed in the permanent exhibit. Such a reproduction would have, for this museum at least, crossed the limits of representation. ${ }^{37}$

\section{D) The Use of Artifacts}

One of the most problematic manifestations of the notion of an ethic of representation in Holocaust museums concerns the use of artifacts. The French philosopher Emmanuel Levinas writes about the notion of the object of representation in his book Totality and Infinity, explaining that, "in clarity an object which is first exterior is given that is, is delivered over to him who encounters it as though it had been entirely determined by him. In clarity the exterior being presents itself as the work of the thought that receives it. ${ }^{338}$ As Levinas demonstrates here, there is a complex relationship between an object and he who views or receives it; there is an encounter taking place between the object and the viewer, with the viewer bringing his thought to bear upon the object whatever that thought may be. The use of artifacts in a Holocaust museum is not, therefore, mere representation of an event, person, or moment from Holocaust history but instead the tense interplay between the object, what that object represents, what the object represents to the viewer, and what that reception ultimately accomplishes in the viewer. There is no 
one single message that an artifact will have, as that artifact is always subject to the viewer's reception of it and is thus open to whatever ethical determination the viewer brings to bear upon it.

For Holocaust museums, there is another central difficulty that accompanies the acquisition of artifacts aside from the problem of representation described above: there are far fewer Holocaust-era artifacts - from the victims, the survivors, and the perpetrators - in existence than there are artifacts from other less violent, less destructive periods of history. ${ }^{39}$ When totalitarian regimes such as the Nazi party set out to destroy a portion of a population, in the process they loot, confiscate, and destroy sacred and ordinary objects - in part to exercise their power and in part to destroy evidence of their regimes. The people whom they target are deprived of their possessions and left powerless to reclaim them. The artifacts that do survive are few, and they are often not in good condition. ${ }^{40}$ These challenges render Holocaust museums' task of locating and displaying authentic artifacts more difficult than the same task is for more conventional museums. The existence of these obstacles also imbues the artifacts that do find their way into Holocaust museums' collections with a greater "moral weight," for their use is evidence that behind the artifact lies the entrustment of it to the museum, that there is a survival story inherent in the artifact, and that there is a potential volatility behind its use in the museum. ${ }^{41}$ The idea that artifacts have moral weight takes on added significance when one considers that the traditional definition of a museum is that it is an "institution in which objects... are the principal means of communication. ${ }^{, 22}$ The artifacts not only bear moral weight but also institutional weight and an obligation to be the primary drivers 
of the museum's narrative. ${ }^{43}$ They are seen as links between the visitor and "the inhabitants of previous worlds and experiences, as connections between the tangible and intangible or visible and invisible worlds." ${ }^{44}$ In a Holocaust museum, artifacts connect the living to the dead. ${ }^{45}$ The historian Mike Wallace cautions against relying too heavily on artifacts despite their power. He argues that "focusing on objects can foster empiricism, make you forget that artefacts [sic] don't speak loudly to untutored ears, and lead to the fetishization of things: industrial machines become lovely objets when presented in gleaming isolation for their original man-eating context."46 The museum has the responsibility to represent the Holocaust through artifacts in a way that does not glamorize them but instead explains their significance clearly and accurately.

Holocaust museum scholar Edward T. Linenthal writes extensively about the use of artifacts — approximately one thousand ${ }^{47}$ in all—displayed at the Holocaust Memorial Museum. Small artifacts shown in the exhibitions include but are not limited to toothbrushes, bowls, anti-Semitic journals, Torah fragments, musical instruments, dolls, drawings, identity cards, and a doctor's smock, ${ }^{48}$ and their use is designed to evoke individual stories in the midst of the larger Holocaust narrative at work in the museum. This tension between the individual stories and the museum's more universal Holocaust narrative surfaces poignantly in a situation that occurred in the Holocaust Memorial Museum's planning stages, one that demonstrates the depth to which artifacts can prompt disagreement about this tension between the museological narrative and the individual. In a design meeting on June 20, 1991 during which a tense discussion arose about the potential display of small items made by inmates in the camps, ${ }^{49}$ items that are 
representative of the individuals who created them and expressive of their own unique personalities and skills. The concern voiced at this meeting included the following arguments for inclusion of the artifacts: that such items illustrate the "'spiritual resistance" "present in the very camps that deprived survivors of almost every aspect of their personhood and that the artifacts would make personal the alienating world of the camps for visitors already struggling to relate to the idea of the camp system. Arguments against using personal artifacts in this portion of the museum included that most inmates would not have thought to make such items and that the artifacts were inappropriately sentimental. None of the arguments above are wrong, per se, making the decision about whether to display the objects even more difficult. The museum staff also wrestled with the knowledge that many survivors considered these small artifacts to be an example of (non-violent) resistance in the camps, disproving the common assumption that they died "like sheep going to the slaughter," obedient and oblivious. At issue here, then, is not just historical accuracy or metonymic representation but the very way that Jews are perceived by the public in response to the museum's narrative and displays.

Representation, then, becomes not simply a curatorial task in Holocaust museums but a moral task as well, one in which a proper understanding of Jews' capacity for resistance during the war is at stake. ${ }^{50}$ The conversations about how to use artifacts in the museum in light of the looming specter of Holocaust denial or in response to concerns about the perception of Jews' resistance are just two of many that took place during the Holocaust Memorial Museum's planning stages, but both sets of issues demonstrate that no artifact stands apart from the moral narrative of the museum. 
Another debate about representation and the use of artifacts that caused enormous friction among museum staff took place in regard to the decision about whether to include human hair that the Nazis had shorn from the heads of female Holocaust victims in the museum's permanent exhibition. The museum had access to nine kilograms of human hair from the State Museum at Auschwitz. Some felt that using the hair would be a good idea because doing so would create a complete, very personal story of the Nazis' assault on human beings and their bodies, especially on women's bodies. Others felt that exhibiting human hair outside of Auschwitz would violate the sanctity and sacredness of these remnants of human life, remove them from their memorial environment, and - even worse - cause the museum to create an exhibit memorable primarily for its grotesque, upsetting nature. Museum staff and survivors assisting with the project argued emotionally over this problem, but Holocaust survivor Dr. Helen Fagin made an argument that brought about a shift in the group's ability to make a decision. She said that "any display of hair would show 'insensitivity and a violation of feminine identity,' and that, for all she knew, the hair displayed could be from members of her family."51 After hearing this statement, the museum decided to keep the hair in its permanent collection storage facility but not display it out of respect for survivors' feelings. There were still lingering concerns, however, that displaying the hair would be an unparalleled way for the museum to communicate the stark reality of the Holocaust. This debate, indirectly perhaps, has influenced other Holocaust museums, for almost none of them exhibit human hair or human remains of any kind, especially not on the large scale originally proposed at the Holocaust Memorial Museum. 
What then emerges as residual from this debate about whether to use human hair is a concern about how and to what degree the museum exhibits the most gruesome aspects of the Holocaust. The question of how to provide visitors with accurate information about the Holocaust in a museum setting can be explored pedagogically and with attention to the question of which media a museum could use for the communication of information. The question of to what degree to tell the "truth" of the Holocaust moves beyond questions of representation and into the realm of a different ethic than an ethic of accuracy—an ethic of aesthetic representation, as mentioned earlier in this chapter. In other words, if the museum is trying to communicate that "the extermination process ...'didn't conclude with just the death of the victims, but...had to include their processing and the auctioning off of the products of their bodies, ${ }^{, 52}$ then it has to make a choice about how deeply the visitor is meant to know this fact—in her mind only or more viscerally. The debate over whether to use human hair shows that there is disagreement about the degree of aesthetic pleasure that should be achieved in the delivery of a given piece of information in the museum. Seeing a picture of mounds and mounds of human hair would certainly be horrible, especially if one is learning the information for the first time, but it is quite arguably horrifying to stand inches from a pile of nine kilograms of human hair and then to learn that it was shorn from Holocaust victims to make yarn and socks. The experience of the real hair in enormous quantity — because quantity is also at issue here and does alter the aesthetic effect—is more aesthetically disconcerting, it seems, than the experience of a picture of the hair or of a small clipping of hair - not in terms of historical accuracy but in terms of its visceral, moral, indelible effect on the visitor. 
When the Holocaust Memorial museum staff members opposed to the use of the real hair argue that the museum can still educate visitors about the horrors of the Holocaust without using the hair and those in favor of using the hair argue that the Holocaust can never be seen as too upsetting, they reveal two different museological and ethical concerns. One issue is that of information delivery, and the other issue is that of effect. Using the situation above as an example, one could argue that yes, visitors to the museum can indeed learn about the Nazis' dehumanizing and looting the living and the dead without an exhibit of human hair. One can also argue that there is a significant difference between a photograph of hair and mounds of real hair. Photographs can be horrifying and disturbing, and respect for that fact is given serious consideration at the museum. It could also be argued, however, that in this case, seeing vast amounts of hair would be jarring and gruesome even if the viewer had no idea from where it came. Being separated from the actual mounds of hair even by a glass wall would still allow the effect of the hair to be extraordinarily powerful. ${ }^{53}$ The question for the museum was whether an understanding of the Holocaust requires the intensely potent experience of being so close to the hair.

This tension between a Holocaust museum's need to create compelling, informative exhibits that also respect the experiences of the victims and the survivors also surfaces strongly in the debate over how to use boxcars - the railway cars used during deportations to transport Jews to the camps - in the museums' exhibitions. Many Holocaust museums have a boxcar in their permanent exhibitions. Yad Vashem, the Illinois Holocaust Museum, the Holocaust Memorial Museum, the Holocaust Museum 
Houston, the Virginia Holocaust Museum, the Florida Holocaust Museum, and the Holocaust Memorial Center all have authentic Nazi-era boxcars on display. The Los Angeles museum and the Virginia Holocaust Museum have replicas of boxcars in their permanent exhibitions. Symbols of both the industrialized killing that characterized the Nazi era and of the deportations that brought so many to their deaths, the boxcars are remnants of "the low-tech but high-efficiency means on which the 'Final Solution' depended." $" 54$

Today the boxcars are an expected component of Holocaust museums. Religious studies scholar Oren Stier argues that the consistent use of the boxcars in museums and visitors' ensuing expectation of them results in their being iconized and idolized, thereby reducing their sacredness and their sanctity. ${ }^{55}$ The problem, explains Stier, is that "for a boxcar to function effectively in a memorial context, it must both encompass and resist identification with the victims who once (may have) occupied its inner space;" the visitor must be able to understand the boxcar historically while not equating his life experiences with those of the victims. ${ }^{56}$ The use of boxcars presents this problem because in many museums, one can actually enter the boxcar, not just look at it from a distance, as at Yad Vashem. When the Holocaust Memorial Museum was being planned, the reason for using a boxcar in its permanent exhibition was, according to exhibition designer Ralph Appelbaum, to give visitors a chance to "experience" the Holocaust. ${ }^{57}$ At the Holocaust Memorial Museum, one can actually enter the boxcar and walk through it or experience being in it. Over time, however, this notion that the visitor could "experience" the 
Holocaust has fallen out of favor. The common understanding is that any pretense of shared "experience" is not only artificial but also morally objectionable.

The art historian Andrea Liss describes her experience of walking into the boxcar at the Holocaust Memorial Museum in moral terms, as a moment of trespassing, of violating the privacy of those who were subject to traveling or even dying in the boxcar. Liss writes:

The railcar marks this perhaps necessary point of trespass...[and] it is the staging of the trampling on the others' privacies that tears at me-my own little trespass and the risk that it conflates in some small way with the original act of violence, the perpetrator's steps. The complex status of the artifact itself calls forth these doubled crossings. ${ }^{58}$

Here Liss finds disturbing and unsettling the idea of herself as in some small, remote way engaging with the boxcar as the perpetrator and in so doing violating the memory and the experience of those who suffered deportation therein. She also explains that the boxcar "demonstrates the tense and difficult role that artifacts are asked to perform in bearing witness to the Shoah: to be objects of empathy and historical proof" and uses the terms "traumatic remnant" and museum planners' notion of the "object survivor" to indicate the magnitude of the boxcar's effect. ${ }^{59}$ The inanimate artifact here—-the boxcar—performs the work of both empathy evocation and historical documentation in the museum, so it must at once be displayed sensitively yet starkly enough to communicate the truth of its role in the Holocaust. What Liss draws into question here is whether it is ultimately too much of a violation to invite visitors into the boxcar, a dilemma that the museum address by not requiring visitors to enter it. It provides a path into the boxcar as well as a way to 
walk around it, leaving the choice to the visitor and in so doing giving each visitor a difficult decision to make.

\section{How Museums Today Use Survivor Testimony}

Since the Holocaust, Holocaust memory has taken up residence in multiple locations: in Holocaust museums and monuments, in literature, in film, and in artifacts. The most authentic and proximate form of Holocaust memory, however, can be found in the eyewitnesses: in the survivors who give testimony, in the recordings made of those testimonies, and in the hearts and minds of those who hear the testimonies. The creation of Holocaust memory in any of its forms, however, relies upon "the ever-changing perspectives in the cycles of life of the survivors, and their personal memories" as its primary source. ${ }^{60}$ As William Robert explains in his essay "Witnessing the Archive: In Mourning, ${ }^{, 61}$ Holocaust survivors are witnesses whose testimonies are addressed to an other, "an other to whom [they] are bound by the bond of an infinite ethical responsibility." ${ }^{\circ 2}$ This ethical responsibility includes the responsibility of the witness to respond to the initial call to testify—modeling herself, as Robert explains, after Abraham's response ("Here I am") to God's call in Genesis 22:1 - to speak, and to speak truthfully. Giving testimony also implies the ethical responsibility that all survivors who give testimony share: the responsibility to speak on behalf of the dead. It is an act of mourning that is on the one hand impossible and on the other hand the only possible way to represent those who can no longer represent themselves.

Holocaust museums have thus always functioned as a second home for survivors and as places where they can bear witness, giving testimony to groups of visitors to the museum 
and to individuals too. The museums have also traditionally served as conduits through which schools and other organizations can arrange to have a survivor speaker visit their institution and give testimony to their particular audience. Over time, however, as survivors have aged and passed on, there are fewer living survivors in general and even fewer who are able to give testimony. The museum community has long been sensitive to the issue of the imminent demise of the survivor population, committing time, energy, and resources to ensuring that survivors' voices are heard in multiple ways in and through Holocaust museums. As Anita Kassof, the Deputy Director of the Museum of Jewish Heritage: A Living Memorial to the Holocaust in New York City, said, "[the museum and other Holocaust museums] will suffer when the survivors" are gone, especially given that live survivor testimony remains the superlative method of "conveying memory authentically."63 Without the survivors, the only available methodologies include that which one already finds in museums: recorded testimony, photographs, films, and artifacts. The shift from live survivor testimonies to only recorded testimonies will also be both a literal shift from in-person testimonies to recorded testimonies and a philosophical shift from immediate contact with survivors to what Berel Lang today calls the "possibility of immediate contact"64 and will eventually perhaps call the "impossibility of immediate contact."

With this shift from the use of live testimony to the use only of recorded testimony comes a specific system of ethics that responds to the inherent tension between the recorded testimony and the viewer of that testimony. Communications scholar Amit Pinchevski writes that the recorded testimonies "capture the uniqueness and authenticity of the 
storyteller... and at the same time allow for public participation and intergenerational communication., ${ }^{, 65}$ The recorded testimonies are therefore crucial elements of a museum's pursuit of authentic, meaningful, intimate engagement with the Holocaust for the visitor. In her essay, "Regarding the Recording: The Viewer of Video Testimony, the Complexity of Copresence and the Possibility of Tertiary Witnessing, ${ }^{, 66}$ Caroline Wake takes the notion of participation and communication with the survivor one step further; she argues that "viewing video testimony is in fact a form of tertiary witnessing," not a primary or secondary form of witnessing. ${ }^{67}$ In tertiary witnessing, she explains, the viewer experiences the testimony as though it were live even though it is a recording; Wake calls this the "liveness effect" of tertiary witnessing. ${ }^{68}$ The sense of immediacy described here is illusory, however emotionally intimate the viewer may feel with the testifier. Wake argues that there is a "double missing" at work here, for the viewer misses the testifier once, for the testifier is already in the past, and again, when the testifier discusses the past within the context of the recorded past. ${ }^{69}$ An "ethics of the visible" is at work here for the "videos bestow a visibility upon the primary witness, which neither erases them nor reproduces them as a spectacle," just as there is also an "ethics of separation" operating. ${ }^{70}$ In this ethic of separation, the testifier becomes separated from his or her testimony, for the testimony survives beyond the survivor and in so doing bestows the ethical importance of the testimony on the recording more so than on either the testifier or the viewer. The recording then in turn has three ethical functions, Wake argues. The first ethical function is that the recording relieves the survivor of the burden of retelling his or her story repeatedly. The second function is that the absence of a live speaker gives the viewer space in which to have inappropriate or 
unethical responses to the testimony without harming the testifier, and third, the recording frees the testifier from the viewer's need to repeat answers. There is no repeated injury done to the testifier in a recording. In all, the recordings seem to serve a positive ethical function. One exception to this rule, however, has to do with what Wake describes as a debate about the "ethics of circulation," the dilemma created when it is possible for testimonies to be over-produced or too widely and easily circulated thanks to the world wide web and the immediate, mass information distribution characteristic of today's technologies. Museums maintain significantly more control over their recorded testimonial content than does a website, but they do not have control over the degree to which their visitors are familiar with recorded testimonies. Given that the reliance on recorded testimonies will only increase as more survivors die, museums do well to consider their testimonies more as "human remains",71 than as mere "recordings."

Two institutions that are not Holocaust museums have also been integral components of this effort to record and preserve Holocaust survivor testimonies: the University of Southern California's Shoah Foundation: The Institute for Visual History \& Education, which has an archive of nearly 52,000 survivor testimonies, ${ }^{72}$ and the Yale Fortunoff Video Archive for Survivor Testimonies, which contains over 4,400 testimonies. There is a difference, however, between the important archival work done to preserve testimonies and live testimonies. In the museum setting, school tours often include a live survivor testimony, and it is this experience that students often cite as the most deeply affecting of all the components of their museum visits. In her book Prosthetic Memory: The Transformation of American Remembrance in the Age of Mass Culture, Alison 
Landsberg writes about creating a permanent sense of memory ${ }^{73}$ in people who did not experience a given event firsthand. Survivor testimonies can be powerful enough to create, in Landsberg's terms, prosthetic memory, or the attachment of a memory to a person who has little or no relation to the event, the people whom the event affected, or the place in which the event occurred. This permanence, prosthetic though it may be, can create an internalization of Holocaust memory even in those for whom the Holocaust initially has no relevance. The question for museums today is: when survivors are no longer able to give live testimony, will their recorded testimonies prove to have the same capacity for permanent alteration? The next section of this chapter examines the ways in which museums are anticipating this question and what efforts are being made to ensure that survivors' voices are still heard in Holocaust museums.

\section{A) The United States Holocaust Memorial Museum—Survivor Testimony}

USHMM's oral history collection contains more than 9,000 testimonies by survivors and by others involved in the Holocaust. One can also visit the museum, meet Holocaust survivor volunteers, hear live survivor testimonies at least once if not twice per week, and hear recorded testimonies where they are integrated into the museum's permanent exhibitions. At USHMM, survivor testimonies are also incorporated into the museum's permanent exhibitions in two especially compelling ways: in its exhibition "Voices from Auschwitz" and in its amphitheater at the end of the museum tour. Voices from Auschwitz is an unconventional museum exhibit in that it is meant to be heard, not seen. The title of the exhibit is etched into glass walls that surround a rectangular space made of Jerusalem stone. Visitors sit on benches built into the walls and listen to survivors' 
voices speaking about their experiences in Auschwitz. There are no photographs or television screens in the exhibition. One is merely meant to listen to the testimonies in what becomes a quiet, intimate setting very different from the more information- and object-driven mode of the rest of the museum. There is the sense that one is being spoken to directly and very personally here.

On the other hand, survivor testimony is presented quite differently later in the museum, for at the very end of the museum tour there is a large Jerusalem-stone amphitheater ${ }^{74}$ with a floor-to-ceiling screen onto which is projected the testimony of Holocaust survivor Gerda Weissman Klein and her husband Kurt Klein, as described in Chapter Three. The presentation of the testimony on such a large screen compels the visitor to watch for at least a moment, and many visitors do sit on the amphitheater's benches, intending perhaps to watch the testimony in its entirety. More interesting to observe, however, are the visitors who remain standing on the outskirts of the seating area. Many seem stopped in their tracks, drawn into the testimony so deeply that they are unable to move- - even to sit down. Though the delivery format is different in this space in the museum and is decidedly more visual than in the more intimately designed Voices from Auschwitz, the effect is similar if not the same: the testimony functions as a one-on-one conversation between the survivor and the visitor to the most superlative degree possible for a recreation of the survivor-visitor interaction. In both testimonial exhibitions cited in this section, the visitor is literally surrounded by the sound of the survivors' voices; the visitor is enveloped in the survivors' memories. One important factor in each of these exhibits is the degree to which the museum has control over the testimonies that are used therein. 
Unlike in a live survivor testimony, in recorded exhibition testimonies the museum chooses which survivors' voices are used, which excerpts from their recorded testimonies would suit the museum's needs best, and how to make them available to the visitor. The use of testimony, then, is not contrived per se but controlled, and it is controlled in order to meet well the goals of having survivors' voices heard and represented in the museum and of creating in the visitor a certain intimacy or sense of kinship with the survivor. In Landsberg's terms, the powerful recorded testimonies serve as catalysts for the grafting on of Holocaust memory to the visitor, with the hope being in this context that a permanent memory will be created in the visitor.

When a museum chooses a recorded testimony, however, it must also take into consideration the risk involved in choosing one survivor's testimony over another's and the risk of choosing one representative voice. The literature scholar Jeremy Hawthorn writes in an essay on the ethics of Holocaust narrative that :

Accounts of individuals risk transforming the exception (survival) into the representative example. More disturbingly, any attempt to make the experience of a single survivor somehow representative of the fate of thousands - or millions - may unintentionally reduce victims to a uniformity that is worryingly reminiscent of the Nazi assertion that all racial Untermensch [sub-humans] are essentially the same...Imagine how we ourselves would feel were we to know that our own life and fate were to be preserved only through the memory of the life and fate of a friend or contemporary who would somehow "represent us."

The tension here is how to avoid giving the impression that all survivors had similar experiences while still using survivor testimony in a meaningful way in the museum. Museum best practices include trying to include video testimony from a wide range of 
survivors and not prioritizing any one survivor speaker over another. As will be seen in the next section of this chapter, only the Los Angeles museum has made an unrivaled effort to represent the widest possible range of voices.

\section{B) Survivor Testimony in The Los Angeles Museum of the Holocaust and the Illinois Holocaust Museum and Education Center}

In the penultimate exhibition room of the Los Angeles museum, there are folding chairs set up for visitors who listen to one of the survivor speakers, who speak on Sundays through Thursdays. All other survivor testimonies in the museum, however, are recorded, not live, and are accessible only through the audio guides, so one must stand in front of an exhibit, press the number on the audio guide that matches the exhibit, and proceed to stand in front of the exhibit to hear the testimony clip, watch the given film clip, or hear another bit of information that the device provides. In April 2012, however, the museum unveiled a new, major exhibition of survivor testimonies: a seventy-screen video sculpture that displays over 52,000 survivor testimonies continuously throughout the year. Each screen shows a different speaker, the audio to which is available on the individual audio guide given to each visitor upon entry to the museum. The testimonies rotate through all 52,000-plus testimonies until the rotation of speakers begins over again. Even though the speakers are not faceless in this exhibition, they are nameless unless one finds the name on the iPod Touch. Ultimately, though, despite the thousands of testimonies presented in this exhibit, there is still no way here to heed Jeffrey Hawthorn's reminder, mentioned in the previous section of this chapter, that the voices of the dead 
need to be heard too- - through readings of surviving letters, poems, and recollections about them from survivors.

In addition, like the Los Angeles museum and as described in Chapter Three, the Illinois museum makes extensive use of survivor testimony. All high school students who take tours of the museum hear a live survivor testimony in the museum's Goodman Auditorium, and recorded survivor testimonies are an intrinsic part of the permanent exhibition. Survivors also volunteer in the museum and serve on museum committees, so their voices are heard in many aspects of the museum. As Curator Arielle Weininger explained, the permanent exhibition at the Illinois museum "is about survivors, not about the massive destruction of European Jewry."76 Weininger's statement is entirely accurate. The original impetus for the museum came from the post-war community of roughly 8,000 Skokie-area Holocaust survivors out of 35,000 Jews in the region, and it is their stories that are told in the museum. One learns about the Holocaust through their eyes and through their voices, that is: through the voices of survivors who represent the victims and the survivors scattered around the world. There thus exists what the philosopher Paul Ricoeur calls "an intermediate level of reference between the poles of individual memory and collective memory, where concrete exchanges operate between the living memory of individual persons and the public memory of the communities to which we belong."77 In the case of a Jewish visitor, that visitor does serve as the exchange between the individual memory of the survivor and the collective memory of the Holocaust operative in the Jewish community. In the case of a non-Jewish visitor, who may or may not have access to a collective memory of the Holocaust, the exchange 
between the survivor and the visitor invites and causes the visitor to join the community of collective memory of the Holocaust, thereby further instantiating Holocaust memory into society, enabling it to reach corners of society that it had not before, and-in theory - thus assuaging slightly the fear of the loss of Holocaust memory.

\section{How Museums Today Address Contemporary Anti-Semitism}

In the Holocaust museums studied in this dissertation, there is extensive information provided to the visitor regarding the rise of anti-Semitism ${ }^{78}$ in Europe before World War II, and there is also extensive information provided about how that anti-Semitism manifest itself against Jews during the war. In the permanent exhibitions of all three museums, however, there is no acknowledgement that anti-Semitism continues to exist today, a fact that seems odd given the extensive attention to the subject of Nazi-era antiSemitism and to the history of anti-Semitism prior to World War Two and given the continued existence of anti-Semitism since the war. Through exhibitions on modern genocide, all three museums acknowledge that violence and prejudice continue to thrive and even escalate into genocide, but there is no concomitant discussion of present-day anti-Semitism. The following section of this chapter is designed to demonstrate the museums' attitudes toward the subject of present-day, resurgent anti-Semitism and to elucidate the tensions that limit museums' interest in the subject.

\section{A) The United States Holocaust Memorial Museum}


At the Holocaust Memorial Museum, the only way to learn that anti-Semitism remains an ongoing problem in today's world is to visit either or both of the Holocaust Memorial Museum's semi-permanent exhibitions, A Dangerous Lie: The Protocols of the Elders of Zion or State of Deception: The Power of Nazi Propaganda, both of which are located on the basement level of the museum. For the former exhibit, the museum specifically chooses not just to educate visitors about the actual text of the Protocols, its content, its history, and its uncovering as fraudulent but also to explain that the lies perpetrated therein are still disseminated around the world and even in the United States - through school textbooks, television programs, and of course the internet. An introductory panel to the exhibit states, "Yet even in the aftermath of the Holocaust antisemitism remains a continuing threat." It goes on to connect the continuing influence of the Protocols of the Elders of Zion with the "resurgence of anti-Semitism today," demonstrating near the end of the exhibit in a section called "Hate and the Internet" that the internet has "made it easy to use the Protocols to spread hatred of Jews." Museum Director Sara Bloomfield speaks about hate, technology, and anti-Semitism in an interview for the museum's online series, "Voices on Anti-Semitism," its podcast featuring different viewpoints on anti-Semitism today. She says,

Teaching people about the Holocaust explains that antisemitism is a very dangerous problem, and that not only can it be carried to ultimate consequences, but it was in recent history. Technological progress seems to be fairly inevitable, but that does not mean moral progress is. The Nazis were a very advanced, educated we could call them a progressive society. In fact, they would have almost defined their social engineering as a sign of their progress. And, I think one of the lessons that as we move into this very interconnected, globalized twenty-first century, that we are learning is the power of hate. I mean, hatred can spread as quickly, you know, as an Internet virus. So I do think that this psychological need for hatred is 
something we better be facing up to about our species, and if we don't we will do so at our own peril. ${ }^{79}$

Here Bloomfield makes several key points, including that technology and morality can be mutually exclusive and that Nazism arose in an advanced, educated society. That said, her language on hatred - "the power of hate"-is an example of the universalizing to which Alvin Rosenfeld so strongly objects, as mentioned earlier. While hate can certainly spread quickly, anti-Semitism yesterday or today cannot be reduced to reductionist notions of "hatred." There is a distinction to be made between hatred and, as the Nazis did, wanting to eradicate all Jews from the earth.

Like Bloomfield, the museum's exhibition State of Deception: The Power of Nazi Propagand $a^{80}$ also tries to connect historical information to the present-day through a discussion of the relationship between technology, morality, and anti-Semitism. In State of Deception, visitors learn about the many forms of Nazi propaganda against the Jews and about how that propaganda was disseminated. They also learn about how hate speech and propaganda are used today, though the exhibit demonstrates this not only regarding anti-Semitism but also as they pertain to other minority groups and as they relate to the pursuit of democracy. The exhibit raises questions about whether a democratic state can place limits on freedom of speech, whether hate speech can be said to incite genocide, whether there is a difference between hate speech and incitement to genocide, and whether hate speech can be considered a crime. The exhibit focuses on themes such as "Making A Leader," "Rallying the Nation," "Indoctrinating Youth," "Defining the Enemy," and "Deceiving the Public," and it includes artifacts such as toy 
soldiers designed to look like Hitler and Nazi soldiers, a Hitler youth armband, and pages from anti-Semitic children's schoolbooks likening Jews to poisonous mushrooms.

Pictures of key Nazi figures abound, as does film footage from Nazi marches, Hitler's speeches, and Nazi filmmaker Leni Riefenstahl's propaganda films.

It is only in the very last section of the rather extensive exhibit that one finds any information about anti-Semitism or anti-Semitic propaganda today. Prior to this final moment of the exhibition, all of the information relates to the Nazis' use of propaganda at the time of the Holocaust. At the very end, though, one's eye is drawn to a flat-screen television. Against a white background, images of newspaper headlines flicker across the screen, with headlines such as "Can Journalism Kill?" from the October 27, 2000 issue of the New York Times. There are other headlines about the use of radio broadcasting in the dissemination of hate speech in Rwanda and one that reads "Iran's New President Says Israel "Must Be Wiped Off the Map." Next to the television screen, there are two panels with text and photographs, one about four Rwandans - the publisher of a Hutu-owned tabloid, the two co-founders of a talk-radio station, and singer-songwriter Simon Bikindi — and one panel featuring Mahmoud Ahmadinejad, the President of Iran. The panel about Rwanda explains how the four men used newspapers, radio broadcasts, and even popular music to incite genocide against Rwandan Tutsis. The panel about Ahmadinejad shows his picture and states that despite his calling for the destruction of Israel, "no judicial action has been taken against him." A final panel attempts, like the brochure, to connect the Nazi propaganda covered in the exhibit to today's world, posing questions such as "What types of propaganda are most problematic? What is the best 
way for societies and individuals to expose and counter deceptive messages? What limits should there be on speech and when? What is the cost [of placing limits on free speech]?” The visitor is left with these powerful and thought-provoking questions, though not, of course, with their answers.

Despite the presence of these two panels and the acknowledgement that anti-Semitism exists at least in the context of the President of Iran, it is only in a brochure found at the entrance to the exhibit that one finds more specific information stated in a forceful way. The brochure, entitled "Antisemitism: A Continuing Threat," quickly explains the meaning of the word anti-Semitism and its use during the Nazi era, then states:

Today, there are signs of increasing antisemitism across Europe and the Islamic world, including hate speech, violence targeting Jews and Jewish institutions, and denial of the Holocaust. Militant Islamic groups with political power used language suggestive of genocide regarding the State of Israel. The president of Iran declared the Holocaust a "myth" and called Israel a "disgraceful blot" that should be "wiped off the map." The Palestinian terrorist organization Hamas pledges in its founding covenant to "obliterate" Israel.

The information presented here is strikingly more direct and concise than any of the information found at the end of the exhibit. Valuable as this knowledge may be toward educating visitors that virulent anti-Semitism still exists today, it is located on the back of a brochure - a brochure that is one of many presented at the entrance to the exhibit and that a visitor may or may not even notice, let alone take the time to read. It is safe to say that most visitors to the museum do not learn in the museum that anti-Semitism continues to threaten Jews today. 


\section{B) The Los Angeles Museum of the Holocaust and the Illinois Holocaust Museum and Education Center}

At the Los Angeles museum, there is no mention of ongoing anti-Semitism whatsoever, though as described above in the section on modern genocide, the museum does indicate that other genocides have occurred since the Holocaust. The museum certainly addresses the subject of anti-Semitism as it pertains to the Holocaust era, as does the Illinois museum, but the only indication that anti-Semitism continues to exist today either in the United States or abroad is a map of neo-Nazi groups in the United States at the Illinois

museum. E. Randol Schoenberg, ${ }^{81}$ the museum's current President and Acting Executive Director, wrote in an e-mail that “our [the museum's] primary responsibility is educating people about the Holocaust and commemorating the victims. Providing the tools to combat present-day anti-Semitism is an obvious byproduct and benefit of the work that we do, but it cannot be our sole focus. There are many other organizations that try to fight anti-Semitism, such as the Anti-Defamation League or the Museum of Tolerance. However, in some sense, I subscribe to my grandfather Arnold Schoenberg's view that it is impossible to fight anti-Semitism, and that our resources should not be wasted in that often futile effort." ${ }^{, 82}$ He later clarified his position here, writing in another e-mail:

an anti-Semite coming through our museum is likely to remain an antiSemite. What our museum can do is teach the people who are not antiSemitic, to help them grow and learn to be better citizens with a greater understanding of history and how the world works. The museum is designed to help make good people better. It probably cannot do much to help turn around the others. To use my grandfather's terms, I see the 
Museum as fighting FOR something, not AGAINST. We provide education for those who are open to learning the truth about the worst crime in the history of humankind. They will be the leaders and the decision-makers of tomorrow. In the end, strengthening the understanding, empathy and resolve of the people who are open and receptive may be the best bulwark against those who, for whatever reason, find the need to attack Jews. ${ }^{83}$

Schoenberg, an ADL Regional Board Member, is hardly alone, however, in thinking that it is not the job of a Holocaust museum to concern itself with present-day anti-Semitism, though the Los Angeles museum does partner with the ADL for programs and cohosts ADL events in the museum. In an interview, Rick Hirschhaut of the Illinois museum, who worked for the ADL for twenty years before coming to the museum ten years ago, stated that "the work [of the museum] is unfinished" and that "we haven't overcome the evils of hate," but he also said that "there is more for [the museum] to do in other areas," that "anti-Semitism is a human problem," not one specific to this museum, and that addressing the problem anywhere in the museum is "not for [him]." ${ }^{84}$ Michael Grunberger, Director of Collections at the Holocaust Memorial Museum, stated, "that's the ADL's job," meaning that it is not the responsibility of the museum but the responsibility of the Anti-Defamation League to confront resurgent anti-Semitism. ${ }^{85}$

\section{Conclusion}

As demonstrated earlier in the discussion of the Holocaust Memorial Museum's debates about whether to include other genocides in the museum, some of the concerns about this inclusion are that doing so detracts from the original intention of the museum, dilutes the integrity of the Holocaust, and opens the door for any group that has suffered to argue for its place in the museum. Alvin Rosenfeld expresses another layer of concern for the 
Holocaust Memorial Museum, asking, “As the museum grows and matures, however, will its conceptual base broaden, in familiar American fashion, to embrace a wider sense of its mission?" ${ }^{\prime 86}$ Here Rosenfeld wonders whether the pioneering spirit that has long characterized America will pervade the walls of a Holocaust museum, causing the museum's mission to expand over the years rather than remaining focused on its original goals—an eventuality commonly referred to as "mission creep."

The Holocaust Memorial Museum's project director during its planning stages, Michael Berenbaum, challenged these claims of Americanization and mission-expansion by arguing that the museum's decision to be inclusive — especially by creating the Committee on Conscience - is being hyperanalyzed. Berenbaum argued that "the 'Holocaust is only "Americanized" insofar as it is explained to Americans and related to their history with ramifications for future policy. The study of the Holocaust can provide insights that have universal import for the destiny of all humanity. A national council funded at taxpayers' expense to design a national memorial does not have the liberty to create an exclusively Jewish one in the restricted sense of the term, and most specifically with regard to audience." ${ }^{87}$ Berenbaum clearly sees the museum as being built for Americans, not just for Jews and not just according to Jewish concerns and appetites. In a sense, all Holocaust museums have since confronted the same issue of audience even though none of them are also located in Washington, D.C. They need to appeal somehow to an audience other than Jews, for if they do not, they will not survive financially. In a way, museums' use of the language of tolerance and their habit of inclusiveness stems from this concern. That said, the issue of drawing in visitors is different from the issue of how visitors are encouraged to connect to the history of the Holocaust once they are 
inside the museum and so that the Holocaust makes an indelible mark on the visitor. In other words, a museum can create superlative exhibitions, programming, and rhetoric designed to have universal appeal and to draw visitors from every corner of a given city, and it can be successful in these efforts, but once the visitors tour the Holocaust exhibitions of the museum, does the history of the time period and the stories of the people affected during it remain a radical other, or is the information presented in such a way that it lodges itself permanently in the mind and body of the visitor?

This question is extremely difficult to answer, as one challenge that Holocaust museums confront is how to gather qualitative information from visitors about their experiences at the museum. In one instance, Yad Vashem did ask visitors to complete a survey designed for this purpose that asked them to choose one or more concepts from a list of emotions if the words applied to how they felt by the end of their visit. The terms included: sadness, thoughtfulness, anger, melancholy, and revenge. The museologist Paul Williams explains that even though it was possible to quantify the qualitative datathe results indicated that $56 \%$ of respondents experienced sadness, $50 \%$ thoughtfulness, and $43 \%$ anger - there is no way to know "whether these feelings were already formed or changed as a result of the museum visit.. ${ }^{, 88}$ There is also no way to know whether the feelings at the time of the visit change in any way over time or are brought to bear upon the future unless the same visitors are followed for decades after the visit, a task that proves nearly impossible. As Williams asks, "What then should we make of the link between visitor response and social action that forms the often-stated raison d'être for memorial museums, ${ }^{, 89}$ especially if it so difficult to know whether or how short-term responses transform into long-term commitments to social justice? 
${ }^{1}$ The political scientist Mitchel Gerber explains that the task of combatting moral indifference means "articulat[ing] a compelling argument exhorting individuals to make the critical transition from ethically indifferent and passive bystanders to active moral agents and rescuers in disparate contexts of genocide" ("Reconstituting Political Philosophy after the Holocaust: Toward the Prevention of Genocide," in The Double Binds of Ethics after the Holocaust: Salvaging the Fragments, ed. Jennifer L. Geddes et al. (Palgrave Macmillan, 2009), 157). In the museological environment, the "context of genocide" is first and foremost to educate visitors about the Holocaust and in so doing underscore the moral difference between bystanders and the righteous.

${ }^{2}$ Norman Geras, The Contract of Mutual Indifference: Political Philosophy After the Holocaust (London and New York: Verso, 1998), 58.

3 "Mission Statement," Los Angeles Museum of the Holocaust, accessed September 4, 2013, http://www.lamoth.org/the-museum/mission-statement/.

${ }^{4}$ E. Randol Schoenberg, e-mail message to author, July 24, 2013.

${ }^{5}$ All italics mine.

6 "Mission Statement," United States Holocaust Memorial Museum, accessed September 4, 2013, http://www.ushmm.org/museum/mission/.

7 "About the Museum: Mission Statement," Illinois Holocaust Museum \& Education Center, accessed September 4, 2013, http://www.ilholocaustmuseum.org/pages/about_the_museum/2.php.

8 “Our Mission," Holocaust Museum Houston, http://www.hmh.org/au home.shtml, accessed August 17, 2013.

${ }^{9}$ Alvin Rosenfeld, The End of the Holocaust (Bloomington and Indianapolis: Indiana University Press, 2011), 249.

${ }^{10}$ Pei Cobb Freed \& Partners, Architects, LLP, accessed September 4, 2013, http://www.pcf-p.com/.

${ }^{11}$ Peter Mostow, "'Like Building on top of Auschwitz:' On the Symbolic Meaning of Using Data from the Nazi Experiments, and on Non-Use as a Form of Memorial," in Journal of Law and Religion, Vol. 10, No. 2 (1993-1994), 409.

${ }^{12}$ Mostow, "Like Building," 409.

${ }^{13}$ Mostow, "Like Building," 409.

${ }^{14}$ Mostow, "Like Building," 410.

${ }^{15}$ Ernst van Alphen, Caught by History: Holocaust Effects in Contemporary Art, Literature, and Theory (Stanford, California: Stanford University Press, 1997), 17.

${ }^{16}$ Van Alphen, Caught, 17.

${ }^{17}$ Holocaust museums are not the only museums that strive to bring about moral change in the visitor. The art educator Kipi Rawlins explains that during the 1960s, museums of all kinds began to favor community involvement and renew their commitments to education, embracing the task of becoming more socially and culturally relevant than the "repressive, hierarchical" culture of the 1950s had permitted. Museums became less the elitist "cabinets of curiosities" that they had been and more places of education and 
personal transformation. (Kipi Rawlins, "Educational Metamorphosis of the American Museum,” Studies in Art Education, Vol. 20, No. 1 (1978): 10.)

18 John Sabini and Maury Silver, Moralities of Everyday Life (Oxford, England: Oxford University Press, 1982), 87.

${ }^{19}$ David H. Jones, Moral Responsibility in the Holocaust: A Study in the Ethics of Character (Lanham, Maryland: Rowman \& Littlefield Publishers, Inc., 1999), 223.

${ }^{20}$ Michael Morgan, "Jewish Ethics after the Holocaust" in Contemporary Jewish Ethics and Morality: A Reader, ed. Elliot Dorff et al. (Oxford and New York: Oxford University Press, 1995), 194-195.

${ }^{21}$ Grieg Crysler and Abidin Kusno, "Angels in the Temple: The Aesthetic Construction of Citizenship at the United States Holocaust Memorial Museum," Art Journal, Vol. 56, No. 1, Aesthetics and the Body Politic (Spring, 1997): 52.

${ }^{22}$ Omer Bartov, "Chambers of Horror: Holocaust Museums in Israel and the United States," Israel Studies, Volume 2, Number 2 (Fall 1997): 70.

${ }^{23}$ James Ingo Freed, "The United States Holocaust Memorial Museum," Assemblage, No. 9 (Jun., 1989): 59-60.

${ }^{24}$ Freed, "United States," 59.

${ }^{25}$ The answer to this question is that, yes, people visiting Washington would come to this museum. According to the museum's quarterly statistics as of December 12, 2012, over 34.8 million people have visited the museum since its opening in April 1993 ("Press Kits: Facts and Figures - Visitors to the Museum," United States Holocaust Memorial Museum, accessed September 4, 2013, http://www.ushmm.org/museum/press/kits/details.php?content=99-general).

${ }^{26}$ Lillian Polus Gerstner, e-mail to the author, August 9, 2013.

27 "News: L. A. Museum of the Holocaust Receives City Council Approval to Open Doors on Saturday," Los Angeles Museum of the Holocaust, accessed September 4, 2013, http://www.lamoth.org/news--events/news/detail/126/.

${ }^{28}$ Freed, "United States," 61.

${ }^{29}$ Freed, "United States," 61.

${ }^{30}$ Freed, "United States," 62.

31 Freed created what the art historian Joan R. Branham calls spatial and "experiential constructs" in the museum that "walked the blurry line between artificial construct and historical presence." (Joan R. Branham, "Sacrality and Aura in the Museum: Mute Objects and Articulate Space," The Journal of the Walters Art Gallery, Vol. 52/53 (1994/1995): 45.

${ }^{32}$ Freed, "United States," 63.

${ }^{33}$ In Unwanted Beauty: Aesthetic Pleasure in Holocaust Representation (Urbana and Chicago: University of Illinois Press, 2007), Brett Ashley Kaplan writes about the pressure on Holocaust museum architects not to reproduce the "fascist architecture" of the Nazi era or to hyper-monumentalize the Holocaust. Their challenge is to create a structure that does not glorify the Holocaust while still designing a building that reflects in some way the serious nature of the museum's content. The design of a Holocaust museum is not to be like other museums, but it must also not reproduce the exact architectural forms of a concentration camp watchtower, for example, and recreate the very structures of oppression. 
${ }^{34}$ Jeffrey Karl Ochsner, "Understanding the Holocaust through the U.S. Holocaust Memorial Museum," Journal of Architectural Education (1984-), Vol. 48, No. 4 (May, 1995): 240.

${ }^{35}$ The biblical prohibition against making graven images challenges the very notion of visual representation, and the art historian Lisa Saltzman writes about this issue in her book Anselm Kiefer and Art After Auschwitz (Cambridge, England: Cambridge University Press, 1999). She writes that "the Second Commandment does not simply proscribe that God should not be portrayed. What the Second Commandment implies is that God cannot be portrayed" (19) and that it "speaks against the worshipping of images" (20). The danger for museums is that while they may not be exhibiting works of art that attempt to depict God, they are exhibiting artifacts such as concentration camp uniforms and Jewish star badges, both of which are now paradigmatic images of the Holocaust. Even if these objects and others like them are exhibited ethically, who can know how far into worship a visitor's gaze veers? Museums can control exhibitions, but they cannot control all that lies behind a gaze.

36 Berel Lang, Holocaust Representation: Art Within the Limits of History and Ethics (Baltimore and London: The Johns Hopkins University Press, 2000), 51.

${ }^{37}$ There is, however, a reproduction of a gas chamber at the Virginia Holocaust Museum in Richmond, Virginia.

${ }^{38}$ Emmanuel Levinas, Totality and Infinity: An Essay on Exteriority, trans. Alphonso Lingis (Pittsburgh, Pennsylvania: Dusquene University Press, 1969), 123.

${ }^{39}$ In her lecture at Northwestern University in 1977, "The Holocaust as Historical Record," the Holocaust historian Lucy Dawidowicz spoke about the difficulty that Jews experienced in hiding and preserving paper documents during the Holocaust. She said, "The Jewish documents are far fewer in number and, in contrast to most archival sources, contain a larger proportion of personal papers than of official records...Under German persecution... [records were maintained] with caution and discretion... Nevertheless, the Jews in the ghettos were resolute in their determination to leave a documentary record for posterity, even if they themselves did not expect to survive" (in Dimensions of the Holocaust, ed. Elliot Lefkovitz, Evanston, Illinois: Northwestern University Press, 1977, 23). Creating historical records was for Jews not just an act of historical preservation but also an act of remembrance and of quiet rebellion.

40 A special example of the destruction of Jewish possessions and sacred objects is the case of the hundreds of Torahs that were seriously damaged during the war. These pasul (defective) sefer Torahs were rescued, preserved by the Memorial Scrolls Trust, and then given to synagogues and museums to serve as reminders of the Holocaust. The ethic of display for a pasul Torah includes that it be kept in a quiet place such as a corner out of the way of crowds, be marked in such a way that it would not be mistakenly read, and be protected from the elements. (Kassel Abelson, "Display of a Pasul Torah in a Museum Case," The Committee on Jewish Law and Standards of the Rabbinical Assembly, June 4, 1997.)

41 Paul Williams, Memorial Museums: The Global Rush to Commemorate Atrocities, ed. Paul Williams (Oxford and New York: Berg, 2007), 25. 
42 Kenneth Hudson's chapter, "Attempts to Define 'Museum," in Representing the Nation: A Reader-Histories, heritage and museums [sic], eds. David Boswell et al. (London and New York: Routledge, 1999), 374.

43 One artifact that almost always figures prominently in the narrative of a Holocaust museum is the boxcar. Oren Stier's essay on the subject of integrating boxcars into Holocaust museum narratives - "Different Trains: Holocaust Artifacts and the Ideologies of Remembrance" in Holocaust and Genocide Studies, Volume 19, Number 1, Spring 2005: (81-106) - explains the notion of "emplacement," or how artifacts are engaged and employed in memorial settings. The essay documents the boxcar emplacement practices of four Holocaust museums: the Dallas Holocaust Memorial Center, the United States Holocaust Memorial Museum, the Florida Holocaust Museum, and Yad Vashem. At USHMM, visitors walk though the boxcar and can see its insides. At Yad Vashem, the boxcar is part of a memorial structure that extends far out from a cliff, rendering the boxcar untouchable and precariously poised. These varying "ideologies" and practices of remembrance give rise to equally variable approaches to Holocaust memorialization regarding whether Holocaust memory should be made intimate to the visitor or kept at a certain distance.

${ }^{44}$ Richard Cohen, "Self-Image Through Objects: Toward A Social History of Jewish Art Collecting and Jewish Museums" in The Uses of Tradition: Jewish Continuity in the Modern Era, ed. Jack Wertheimer (Cambridge, Massachusetts and London: Harvard University Press, 1992), 205.

${ }^{45}$ For a detailed critique of another museological option to the artifact-based museum, see Oren Baruch Stier's article "Virtual Memories: Mediating the Holocaust at the Simon Wiesenthal Center's Beit Hashoah-Museum of Tolerance," Journal of the American Academy of Religion, Vol. 64, No. 4, Thematic Issue on "Religion and American Popular Culture" (Winter, 1996), 831- 851. Here Stier concludes that the Museum of Tolerance's reliance not upon artifacts but primarily upon audio-visual technology contributes, in large part, to "tradition and memory [being] largely ignored, pushed to the sidelines in favor of a multi-media spectacle that ultimately fails to mediate much of anything" (848).

${ }^{46}$ Mike Wallace, "Changing media, changing messages," in Museum, Media, Message, ed. Eilean Hooper-Greenhill (London and New York: Routledge, 1995), 110.

${ }^{47}$ Unless indicated otherwise, the following discussion of the use of artifacts at the Holocaust Memorial Museum is drawn from Edward T. Linenthal's Preserving Memory: The Struggle to Create America's Holocaust Museum (New York: Columbia University Press, 1995), 189. As of 11/04/2013, the museum owned 17, 825 objects, with an average of five or six new objects acquired per week. ("Press Kits: Facts and FiguresCollections and Reference Services," United States Holocaust Memorial Museum, accessed November 4, 2013, http://www.ushmm.org/information/press/press-kits/unitedstates-holocaust-memorial-museum-press-kit/.

${ }^{48}$ Linenthal, Preserving Memory, 189.

${ }^{49}$ Linenthal, Preserving Memory, 190.

${ }^{50}$ In his essay "Museums as Contact Zones," James Clifford writes about his experience consulting for a group of Tlinglit elders and museum staff at the Portland Museum of Art in Portland, Oregon in 1989, a story worth recalling here because it illustrates the complex relationship between artifacts, the cultures of which they are a part, and the 
representation of the past through the artifacts. The elders had been invited to participate in planning discussions for a reinstallation of the museum's Northwest Coast Indian collections. As Clifford explains, "the curatorial staff...expected the discussions to focus on the objects of the collection," but the elders "seemed to use them as aides-mémoires, occasions for the telling of stories and the singing of songs." By the end of the meeting, the curators understood that while they had been looking at the objects as "art," for the Tlinglit, the objects were "'records,' 'history,' and 'law,' inseparable from myths and stories expressing ongoing moral lessons with current political force." The question for the museum staff then became how to exhibit the objects in an art museum in a way that respected their mythical, narrative, and ethical role in Tlinglit culture - a tall order indeed. (James Clifford, "Museums as Contact Zones," Representing the Nation: A Reader-Histories, heritage and museums, ed. David Boswell et al. (London and New York: Routledge, 1999), 435-437).

${ }^{51}$ Linenthal, Preserving Memory, 214-215.

${ }^{52}$ Linenthal, Preserving Memory, 211-212.

53 The debate about whether to use human hair at the Holocaust Memorial Museum exemplifies what anthropologist and museologist Sharon Macdonald describes in her book The Politics of Display: Museums, Science, Culture (London and New York: Routledge, 1998), 231: "Studies in this book have identified the multiple players and sometimes contradictory agendas which may be involved in exhibition-making, the socio-political milieux within which exhibitions take on their meanings, ways in which particular display strategies may articulate with these, and perspectives from which visitors may interpret displays." All of these factors - from the multiple players to the differing agendas to the perspectives of a diverse visitorship - are at work in the debate here.

${ }^{54}$ Berel Lang, Holocaust Representation: Art within the Limits of History and Ethics, (Baltimore and London: The Johns Hopkins University Press, 2000), 96-97.

${ }^{55}$ Oren Stier, Committed to Memory: Cultural Mediations of the Holocaust (Amherst and Boston: University of Massachusetts Press, 2003), 39-40.

${ }^{56}$ Stier, Committed to Memory, 214.

${ }^{57}$ Tim Cole, Selling the Holocaust: From Auschwitz to Schindler-How History is Bought, Packaged, and Sold, (New York: Routledge, 2000), 161.

${ }^{58}$ Andrea Liss, Trespassing Through Shadows: Memory, Photography \& the Holocaust (London \& Minneapolis: University of Minnesota Press, 1998), 71.

${ }^{59}$ Liss, Trespassing, 71-72.

${ }^{60}$ Dalia Ofer, "The Past That Does Not Pass: Israelis and Holocaust Memory," Israel Studies, Volume 14, Number 1 (Spring 2009): 29.

${ }^{61}$ William Robert, "Witnessing the Archive: In Mourning" in Religion, Violence, Memory, and Place, ed. Oren Baruch Stier et al. (Bloomington and Indianapolis: Indiana University Press, 2006), 37-50.

62 Robert, "Witnessing the Archive," 38.

${ }^{63}$ Interview with the author, August 10, 2012 at the Museum of Jewish Heritage, New York City.

64 Berel Lang, Post-Holocaust: Interpretation, Misinterpretation, and the Claims of History (Bloomington and Indianapolis: Indiana University Press, 2005), 77. 
${ }^{65}$ Amit Pinchevski, "Archive, Media, Trauma," in On Media Memory: Collective Memory in a New Media Age, eds. Motti Neiger et al. (Palgrave Macmillan: 2011), 257. ${ }^{66}$ Caroline Wake, "Regarding the Recording: The Viewer of Video Testimony, the Complexity of Copresence and the Possibility of Tertiary Witnessing," History \& Memory, Vol. 25, No. 1 (Spring/Summer 2013), 111-144.

${ }^{67}$ Wake, "Regarding," 111.

${ }^{68}$ Wake, "Regarding," 126.

${ }^{69}$ Wake, "Regarding," 130.

${ }^{70}$ Wake, "Regarding," 132.

71 I borrow this phrase from Clifford Chanin, Education Director of the 9/11 Memorial Museum. In a talk at the Museum of Jewish Heritage-A Living Memorial to the Holocaust on March 5, 2013, Chanin explained that he uses the phrase "human remains" to describe the recorded phone calls that victims made from the World Trade Center Towers and from the hijacked airplanes to their loved ones. These phone calls are not simply referred to as "recordings."

72 The Shoah Foundation is currently working with the University of Southern California's Institute for Creative Technologies to create Holocaust survivor holograms: three-dimensional holograms of Holocaust survivors that will preserve their images and their testimonies in perpetuity. The images of the survivors are not broadcast onto a screen but into open space so that one can interact with them and ask them questions. The intention is for the holograms to be used in classrooms, at business conferences, and in situations in which there is the need for an "expert opinion on subjects when real people can't be there to do so." The article also states that the holograms could be used in still other arenas, explaining that "they could even be used as teaching tools for people studying to become therapists who aren't quite ready to work with a real, emotionally troubled person." (The AP, February 2, 2013 (1:18 p.m.), "Holograms retelling Holocaust survivors' stories," USA Today, http://www.usatoday.com/story/news/nation/2013/02/02/holocaust-holograms-survivorsstories/1886075/.)

${ }^{73}$ Alison Landsberg, Prosthetic Memory: The Transformation of American Remembrance in the Age of Mass Culture (New York: Columbia University Press, 2004), 113.

${ }^{74}$ The museum's use of Jerusalem stone in both Voices from Auschwitz and in its amphitheater resonates with meaning. Barbara Mann writes about American Jewish institutions' frequent use of Jerusalem stone in her book Space and Place in Jewish Studies (New Brunswick, New Jersey, and London: Rutgers University Press, 2012). She explains that "in addition to the more overt reference to the distant center [Jerusalem]...the presence of Jerusalem stone...may also represent another type of portable homeland, an allusion to the locative mobility of Judaism's institutions - a wink and a nod that suggests 'Jersualem is here.' (57)." To the unwitting viewer, the use of the stone is unremarkable except perhaps for its beauty. To the knowing viewer, however, the stone links the testimonies to Jerusalem regardless of whether the survivor who is speaking lives there or has even been to Israel. The stone implies a permanent and unbreakable connection between survivors of the Holocaust, the land of Israel, and the museum. 
${ }^{75}$ Jeremy Hawthorn, "The Face-to-Face Encounter in Holocaust Narrative," in After Testimony: The Ethics and Aesthetics of Holocaust Narrative for the Future, ed. Jakob Lothe et al. (Columbus, Ohio: Ohio State University Press, 2012), 144.

${ }^{76}$ Illinois Holocaust Museum, interview with the author, August 7, 2012.

${ }^{77}$ Paul Ricoeur, Memory, History, Forgetting, trans. Kathleen Blamey and David Pellauer (Chicago \& London: University of Chicago Press, 2004), 131.

${ }^{78}$ The British scholar of Judaism and Christianity Hyam Maccoby defines the term "antiSemitism" in his essay "Anti-Judaism and Anti-Semitism." He writes: "It is generally agreed that the term anti-Semitism should be used not in its purported sense of 'antagonism to Semites' but as the equivalent to 'Judaeophobia' or 'Jew hatred"' and "is thus parallel to Anglophobia or Francophobia, and means a hatred of Jews at the paranoid level" (Arthur A. Cohen and Paul Mendes-Flohr, eds, Contemporary Jewish Religious Thought: Original Essays on Critical Concepts, Movements, and Beliefs, (New York, New York: The Free Press, 1987), 14).

79 "Voices on antisemitism," Sara Bloomfield, United States Holocaust Memorial Museum, accessed September 3, 2013, http://www.prx.org/pieces/17854/transcripts/17854.

${ }^{80}$ The museum defines propaganda as "biased information designed to shape public opinion and behavior." ("Resources: What is Propaganda?," United States Holocaust Memorial Museum, accessed September 4, 2013, http://www.ushmm.org/propaganda/resources.)

${ }^{81}$ Schoenberg is a practicing attorney in the Los Angeles area. His biography ("E. Randol Schoenberg," accessed September 4, 2013, http://www.bslaw.net/schoenberg.html), reports that he has litigated prominent cases including Republic of Austria v. Altmann, for which he sought return of six famous Klimt paintings to Maria Altmann, from whose family the Nazis seized the paintings. The biography reports that, "after persuading the United States Supreme Court that Maria Altmann could sue Austria for return of the paintings, Schoenberg agreed to arbitrate the dispute in Austria. In January 2006 the arbitration panel decided that the paintings, valued at over $\$ 325$ million, should be returned to Mrs. Altmann." Schoenberg has been a member of the Board of Directors of the Los Angeles museum for more than a decade.

${ }^{82}$ Randol Schoenberg, e-mail to the author, July 24, 2013.

${ }^{83}$ Randol Schoenberg, e-mail to the author, July 25, 2013.

${ }^{84}$ Richard Hirschhaut, interview with the author, June 16, 2013.

${ }^{85}$ Michael Grunberger, interview with the author, Washington, D.C., May 2, 2012.

${ }^{86}$ Alvin Rosenfeld, The End of the Holocaust (Bloomington and Indianapolis: Indiana University Press), 66.

${ }^{87}$ A. Rosenfeld, End, 67.

${ }^{88}$ Paul Williams, Memorial Museums: The Global Rush to Commemorate Atrocities

(Oxford: Berg Publishers, 2007), 146.

89 Williams, Memorial Museums, 146. 


\section{CHAPTER SIX: TWENTIETH-CENTURY GENOCIDE AND UNITED STATES HOLOCAUST MUSEUMS}

There are three essential reasons why Holocaust museums today continue to address the subject of modern genocide in their permanent exhibitions: genocides and mass violence took place before the Holocaust, were taking place while the Holocaust Memorial Museum was being planned, and have continued to occur since. When the United States Holocaust Memorial Museum opened on April 22, 1993 — with what Elie Wiesel saw as its mission, "confronting hate, preventing genocide and promoting human dignity"1_ it was directly confronted with the problem that ethnic cleansing, rape, torture, concentration, and mass killings were taking place in Bosnia-Herzogovinia to a degree not seen since the Holocaust. At the ceremony marking the museum's opening, Wiesel turned and said to then-President Bill Clinton, "We cannot tolerate the excruciating sights of this old new war...Mr. President, this bloodshed must be stopped." ${ }^{2}$ Clinton did not respond directly to Wiesel's request, but he did say, "we learn again and again that the world has yet to run its course of animosity and violence... ethnic cleansing in the former Yugoslavia is but the most brutal and blatant and ever-present manifestation of what we also see" in other instances of violence and oppression around the world. ${ }^{3}$ The juxtaposition between Wiesel's heartfelt plea to Clinton, Clinton's evasion of the request, and the sight of 68-year-old Holocaust survivor Marcia Krause wandering through the rain "amid the 8,000 guests with a sign hanging from her neck bearing her maiden name and hometown in Poland in a futile search for family members" served as a stark, chilling reminder of the inadequacy of the post-Holocaust mantra, "Never Again," to prevent future genocides and of the enormity of the human loss inherent in a genocide. ${ }^{4}$ 
This sentiment of concomitance with other genocides renders the subject inescapable for Holocaust museums small or large. Philosophically, the fact of seemingly unremitting genocide collides with (1) the conviction that it is immoral to differentiate the Holocaust as "unique" over and above all other genocides and (2) the grief and fear that accompany the imminent loss of Holocaust memory as survivors die. This collision yields the inescapable compulsion to document other genocides and a feeling of moral obligation to do so. In other words, if it is morally unacceptable to argue publicly that the Holocaust is unique, and if there is both fear and sadness about a world without the memorializing witness of Holocaust survivors, then there will be varying degrees of acknowledgement of other genocides in Holocaust museums and an attempt to instantiate Holocaust memory through subjects that are perceived to be relevant today. Arguments against including modern genocide suggest that introducing the subject of modern genocide into a Holocaust museum's permanent exhibition space or programming "space" is problematic because doing so can be seen as representing an intrusion upon the sanctity of the very event that is meant to have prominence in the museum. In this way, documentation of other genocides can be seen as eroding or dissolving the integrity of the Holocaust exhibitions, as can mission statements that employ a broad language of tolerance and "inclusiveness" instead of focusing solely on Holocaust commemoration and education. At the same time, for museums concerned about how to remain relevant in a world that is increasingly fast-paced, digital, and removed in time from the Holocaust, exhibitions on recent and current genocides and on human rights violations could be crucial to preserving relevance and to drawing younger visitors. This chapter documents the tensions related to the inclusion of the subject of modern genocide in 
Holocaust museums, the ways in which Holocaust museums today present modern genocide, and the implications of the museums' decisions in this arena.

\section{The United States Holocaust Memorial Museum: From Memory to Action}

When the Holocaust Memorial Museum was in its planning stages, the staff faced an ethical dilemma over whether to include other genocides in the museum's exhibitions that was problematic, inflammatory, and tense. The crux of the debate had to do with the Armenian genocide, which began in Turkey in 1915 when the Young Turks, the political party leading the Ottoman Empire, killed over 1.5 million Armenians. As Linenthal explains, the "argument that recognition and representation of the Armenian genocide was part of the commission's responsibility surfaced in their first meeting in February 1979, when Raul Hilberg declared that 'it would not be a fulfillment of the overall task' to ignore Armenians or other victims." ", The conversation about whether to include the Armenian genocide in the museum grew from here, and the voices arguing for and against the inclusion were loud and distinct.

The Armenian community argued that "somewhere, somehow, the Armenian genocide, at least as backdrop, has a role in [the Holocaust Memorial Museum's] work" and that if the museum's planning committee determined that it did not, then it was "indeed in trouble...[for] who will listen if not [a Holocaust museum]?"6 The pressure was immediately put onto the planning committee to take responsibility for the history of other genocides, and that pressure continued over time. In 1980, museum council member Set Momjian told the council of "his hope that 'all peoples who have been the victims of genocide can look forward to a completed museum and an educational 
program that will tell the complete story of man's inhumanity to man,"' and he then promptly pledged one million dollars to the museum on behalf of the Armenian community in the United States. ${ }^{7}$ Again, tremendous pressure was brought to bear on the museum to be "inclusive" and "representative" of other groups against whom genocides had been perpetrated.

There were also arguments against including the Armenian genocide in the museum. Yaffa Eliach said that "she was willing to include the millions of non-Jewish victims of the Nazis [such as Jehovah's Witness, homosexuals, and Roma-Sinti], but not events that took place in 1915. She worried about the slippery slope of inclusion on non-Holocaustrelated genocides." 8 By using the term "slippery slope" she means to question how the museum could represent only one non-Holocaust genocide without then being equally obligated to mention others, especially current or ongoing genocides. Miles Lerman expressed the same fear and "spoke for the concerns of many when he worried about extending Holocaust memory too far backward. [He said that] 'if you are introducing the Armenian tragedy to the Holocaust, why not the tragedy...of the Cambodians? Why not the tragedy of the American Indians?",9 Eliach and Lerman are justified in pointing out that it would indeed be a tall order for one museum to do justice to the history of so many different peoples, and they are justified in questioning whether, on a practical level, it is ever wise to take on such an enormous task. In addition to these philosophical problems, the council also felt pressure from the Turkish government, which denied and still denies to this day that any genocide against the Armenians ever occurred and which was vehemently opposed to the inclusion of the Armenian genocide in the museum. 
"Monroe Freedman, the council's first acting executive director, recalled, 'As much as anyone wanted to be represented in the museum, that's how much the Turkish government wanted the Armenians out. There was pressure on us, and pressure on the White House Staff working with us...."10 As Freedman demonstrates, the museum was caught between the two sides of a deeply contentious political debate.

It was also caught between contentious internal debates, complicating matters further. In response to the arguments cited above that resisted including the Armenian genocide in the museum, there were more voices on the council in favor of including the Armenians. Holocaust scholar Yehuda Bauer pointed out that "the 'denial of other people's genocides would expose [the museum] to a tremendous wave of criticism, and would be morally absolutely contemptible."'11 Here Bauer brings two important concerns to light: the concern about how the museum, which had yet to be even built, would be perceived by the public both in its planning stages and after it opened, and the concern about the moral integrity of a decision to omit the Armenian genocide. Michael Berenbaum, the Holocaust scholar who was then Project Director at the museum, also advocated for inclusion, arguing that "exclusionary policies" would be

'a historical mistake which undermines the integrity of this...exhibition, and a pedagogical mistake which diminishes our ability to reach out and to include groups who naturally can see in the Holocaust a sensitive metaphor to their own experience. These groups include Native Americans and Blacks and their exclusion because of the Armenian question is idiocy. It is also short sighted for our visitors and our critics will ask again and again as they have in the past what about Native Americans? The Cambodians? Furthermore, it undermines our professional standing among those who have studied the Holocaust and genocide and it evinces the politicization of our mission. ${ }^{12}$ 
Berenbaum's fear here has to do in part with alienating a museum audience already experiencing the alien. If the average visitor is not Jewish and knows little about the Holocaust, then the history and the people presented in the museum are radically different to what the visitor has ever known. If the visitor has never been to a museum before, then the experience of being in the building and the experience of what would be a radically different, "raw" structure are also deeply alien to the visitor's previous experiences and potentially in contrast to her expectations. As Ochsner writes, "the difficulty of achieving any kind of identification in the Holocaust Museum - that is, overcoming the otherness of those involved in the Holocaust—returns to the difficulty of overcoming the distance between our own lives and the experience of life in central and eastern Europe before World War II." ${ }^{, 13}$ Bridging this gap between the self and the other represents one of the greatest challenges of any Holocaust museum pedagogically speaking, but in the context of the debate about whether to include other genocides, the challenge takes on moral overtones too. The question becomes, "just how does the museum's pedagogical address open up access to the moral imperative that visitors apply their experience of the museum to their contemporary lives, without specifying what the visitors should do?"14 The museum should be instructive but not overly didactic, and in this way should give rise to thoughtful reflection and to the sensitivity of which Berenbaum spoke, for if the visitor finds nothing of herself in the museum, then the opportunity for her to inhabit a "sensitive metaphor" dissolves, and the museum remains irrelevant to her. These pedagogical "mistakes" pale in comparison, though, to Berenbaum's concerns about the museum's becoming yet another example of how marginalized non-white, non-American cultures and their histories can be in the United 
States. In addition, Berenbaum wanted the museum to be professional, to respond to the needs of collective memory, and not to be a mere function of politics.

In some ways, the Committee ultimately agreed with him on one level, as the development and existence of the Holocaust Memorial Museum's Committee on Conscience attests. The museum describes the Committee's history as follows:

When the President's Commission on the Holocaust recommended in 1979 the creation of a living memorial to the victims of the Holocaust, it observed that no issue "was as perplexing or as urgent as the need to insure that such a totally inhuman assault as the Holocaust - or any partial version thereof - never recurs." To address that need, the President's Commission recommended creation of a Committee on Conscience, a committee of the Museum's Council.

The Museum opened in 1993, and shortly thereafter, Leo Melamed, whose family fled Nazism, formally proposed the establishment of the Committee on Conscience as a standing committee to his fellow members of the United States Holocaust Memorial Council. His proposal received unanimous approval in $1995 \ldots$. The Committee on Conscience mandate is to alert the national conscience, influence policy makers, and stimulate worldwide action to confront and work to halt acts of genocide or related crimes against humanity.... ${ }^{15}$

The unanimous acceptance of the proposal, however, should not be taken to mean that the path to the official establishment of the proposed committee was at all smooth. When the idea for the Committee was first explored in the 1980s, museum council members Terence Des Pres, the Holocaust scholar, and Ingeborg G. Mauksch, the nurse and humanitarian who escaped pre-war Austria by immigrating to the United States, ${ }^{16}$ raised concern about the role of on-site surveys in documenting potential or existing genocides. 
First, Des Pres argued that such surveys were incredibly difficult though they were crucial to establishing credibility, and Maukusch said that "an effort to evaluate genocidal situations must include on-site surveys whenever possible." ${ }^{, 17}$ Their prioritization of establishing credibility for the museum and making accurate assessments of genocidal "hot-spots" set a high ethical, professional, and academic standard for the future Committee on Conscience from the outset, also demanding by implication significant time, money, and energy for the endeavor.

At a meeting in New York City on July 23, 1980, the subcommittee appointed to articulate the function of the Committee debated a wide range of ideas. Des Pres said that it should pass the Genocide Convention; Arthur Davis, Mario Cuomo, Willard Fletcher, Eli Zborowski, and Mauksch argued that it should not be affiliated with the government at all; Fletcher added that it should be modeled after Amnesty International; Harry Cargas countered that it should be modeled after the Nobel Foundation and that it should give an annual award "for those who help to or actually expose incidents of genocide;" and Davis and Bayard Rustin argued that the Committee should be affiliated with the government in order to attract the right caliber of person to serve on it. ${ }^{18}$ As the diversity of ideas that emerged from this meetings demonstrates, the subcommittee members faced a difficult task here: determining what a Committee on Conscience should do, what it should look like, and whether it should it be affiliated with the government, the very government it might need to criticize if a genocide were to take place and the Committee were to be dissatisfied with the government's response. 
After almost a decade of debate, research, exploration, and the eventual opening of the Holocaust Memorial Museum, the museum formed what it called the Ad Hoc Exploratory Group, a subcommittee of board members asked to make final decisions regarding the Committee on Conscience. The group met at the museum on December 6, 1993, but by the time of its next meeting, on May 24, 1994, the Rwandan genocide had taken place. The subcommittee grappled with how to react. Committee member Hyman Bookbinder, the Washington lobbyist who served as the Washington representative for the American Jewish Committee for nineteen years, ${ }^{19}$ was passionate. He said,

We are survivors, or colleagues of survivors, who every chance we get, we make speeches about why Roosevelt didn't do things, why people weren't be alerted [sic], why, in the face of information, nothing was done. Well, how the hell can we make those kinds of speeches and seem to be rather calm about what kind of vehicle we need, whether it should be with the structure, or not within the structure. Those are so unimportant compared to the determination of judgment to be made consistent with what we said 12 years ago. ${ }^{20}$

Here Bookbinder referred to the original subcommittee's discussions in the early 1980 s that the Committee will "research genocidal and potential genocidal situations and present to members... wherever it is possible, make fact finding or on-site surveys to determine credibility... [and] will issue statements to the President of the United States, the American Congress, members of the press, religious and civic leaders in order to motivate both government and private institutions to take such action as necessary."21 Bookbinder wanted the committee to act on the promises it had made to alert the government and the public in the event of a genocidal situation, but more importantly, he 
was urging the committee not to be hypocritical. If the museum was critical of Roosevelt and of wartime bystanders, then the only moral option was now to cry out - and act - in support of Rwanda.

As it evolved, the Committee on Conscience has acknowledged other genocides through hosting speakers, supporting fact-finding missions, commissioning studies, and providing extensive content on its website: recorded eyewitness testimonies, maps, photographs, podcasts, and learning resources. It was ultimately not until decades later, in May of 2009, that the Committee on Conscience opened an exhibition on modern genocide entitled "From Memory to Action" that was, according to Jackie Scutari, the Program Coordinator for the museum's Center for the Prevention of Genocide, originally intended only for a five-year run, but as of May 2013 there were no plans to remove the exhibit. ${ }^{22}$ While various departments in the museum use the exhibit for their educational and training programs and to prompt discussion about "concepts such as moral responsibility, ${ }^{, 23}$ the typical visitor only sees the exhibition after exiting the museum's permanent exhibition, if at all, and without a guide or facilitator. After arriving on a landing, one can see to the right the main lobby of the museum, the Hall of Witness, and to one's left, a small gift shop next to the entrance to From Memory to Action. The museum's website describes the exhibition as follows:

[From Memory to Action is] an interactive installation that uses cutting edge technology and compelling eyewitness stories to invite visitors to join a growing community of people taking action against genocide. Located in the Museum's Wexner Center, the installation introduces visitors to the concept and law of genocide, to three contemporary cases of genocide - Rwanda, Srebrenica in Bosnia-Herzegovina, and the Darfur region of Sudan — and to eyewitness testimonies from activists, survivors, 
rescuers, journalists, humanitarian aid workers, and more. It also poses the question to each visitor: "What will you do to meet the challenge of genocide? 24

From Memory to Action ${ }^{25}$ is constructed in a room about the size of a typical living room. When one enters, one sees to the left a series of three text ribbons - one each for Rwanda, Bosnia, and Darfur. Taken together, they reveal a comparative method of presenting the subject. ${ }^{26}$ At the top, there are thematic titles such as "Scapegoating," "Armed Conflict," and "Preparation." If one stands in front of the titles and reads downward, one learns about how each of the three regions experienced this particular element. The ribbons stretch about halfway around the room, stopping just before an exit doorway. Here one has two choices: to circumnavigate the exhibit three times in order to read about each individual genocide horizontally and linearly, or to read vertically and thematically, thus reading about three genocides at once under each theme. On the wall on the other side of the exit, one finds giant digital panels on a wall referred to as the "Pledge Wall" and a long desk-like area with chairs in front of it. One is meant to sit at the desk and fill out a card that reads "TAKE ACTION: What will you do to meet the challenge of genocide today," write an answer on the card, and put it into a slot in the desk. As the website explains, visitors are supposed to "make a personal pledge to take action, share ideas about possible actions, and witness the growing community of people who care about preventing and responding to genocide."27 (One can also make a pledge through the Committee on Conscience's website and view other pledges there, so the notion here is to create a virtual, global pledge community.) The pledges, of which the museum had collected over 160,000 as of May $2013,{ }^{28}$ are then processed digitally so that 
they appear on the large screen on the wall behind the desk, though the museum has no way of knowing whether individuals follow through on their pledges. On the Pledge Wall's section of the Committee's website ${ }^{29}$, there is a repeating loop that displays sample pledge cards, ostensibly filled out by visitors. A few examples of pledge card statements include: "Never Again should mean Never Again," "I will remember what I have seen today," "I pledge to always treat others with the respect they deserve and do my best to be a better person," and "I promise to treat others fairly." Other pledges mention taking actions such as writing letters to government officials, blogging about genocide, and teaching (high-school age) students about genocide. One reads, "I will use my law degree to protect women's rights and gender equality." These pledges provide an interesting glimpse into visitors' understanding of what it means to try to "prevent" or, as the exhibit asks, "meet the challenge of genocide today." The law student responds to the relationship between genocide and violence against women. Others react to the important and problematic relationship between memorialization and genocide prevention. Some want to take on greater personal moral responsibility in their lives as a result of what they have learned about modern genocide from this exhibit and from the rest of the museum, through which they have typically already been.

On the other side of the room in front of the text ribbons, there is a large, shiny table with multiple television screens dangling overhead. The "table" is actually a giant touchscreen computer; it looks like an oversized iPhone but without the "app" icons. Visitors are allowed to touch the screen, and when they do, links to testimonies from genocide survivors, military personnel who were "on the ground" in countries in crisis, and so on 
appear. (These testimonies also play on the overhead monitors mentioned above.) Each testimony has a bar code that one can scan onto the paper card that one is given upon entering the exhibit. The paper card stores the information from the table, and at home one can go to the exhibit's website, type in the code from the paper card, and retrieve the digital data that one "stored." Finally, in addition to From Memory to Action, the Holocaust Memorial Museum has one more exhibit on Darfur, which it calls "Genocide Emergency: Darfur, Sudan." One finds this exhibit if one leaves From Memory to Action and walks through a small exhibition on the Nuremberg trials. Genocide Emergency implores visitors to be aware of genocide, and in a statement stenciled on the wall, it argues that all countries and the entire "civilized world" should be concerned about genocide. The exhibit includes factual information about Darfur and labeled photographs from a museum staffer's visit to the region.

The curator of From Memory to Action was Bridget Conley-Zilkic, who writes about its creation in her essay "What Do You Want? On Witnessing Genocide Today." ${ }^{30}$ Here Conley explains that the goal of the exhibition was to encourage visitors to stay in the museum just a little bit longer to learn about contemporary genocide. The challenge was then one of what Conley calls "proximity," or how to understand "where one is in relation to a threat of genocide" given that for any visitor in the museum at that moment, there is not a real threat of genocide, knowledge of the subject is limited, and the authority to prevent genocide is nil. ${ }^{31}$ Conley explains the dilemma another way, writing that "Balancing the call to action with respect for the alterity of such violence is the struggle of proximity." 32 The problem that Conley identifies here, that the museum must 
find a way to connect the visitor to the material presented and to a desire to act despite the chasm of alterity, or the sense of otherness inherent in the visitor's gaze. Only perhaps a genocide survivor or survivor of other violence would not feel distant from the time periods and types of violence represented in the museum, both in the permanent exhibition on the Holocaust and in From Memory to Action. In From Memory to Action, the use of testimony and the use of the pledge wall are intended to create the sense of proximity for which Conley strives.

Besides creating exhibitions, the Committee on Conscience and the museum sponsor publications and hosts events on the subject of modern genocide, always with highprofile speakers and other participants. Along with the American Academy of Diplomacy and the Endowment of the United States Institute of Peace, in 2008 the museum sponsored former Secretary of State Madeleine Albright and former Secretary of Defense William S. Cohen—co-chairs of the Genocide Prevention Task Force-in their writing of Preventing Genocide: A Blueprint for U.S. Policymakers. ${ }^{33}$ Written on the occasion of the sixtieth anniversary of the Convention on the Prevention and Punishment of the Crime of Genocide and on the twentieth anniversary of the United States' ratification of the treaty, the blueprint intends to equip the United States and its international partners with the information required to "take preventive action [and]...to forestall the specter of future cases of genocide and mass atrocities. ${ }^{34}$ In more than one hundred pages, Albright and Cohen cover topics ranging from developing early warning systems to reversing escalation to creating an international network for sharing information that could lead to the prevention and cessation of genocide. In addition to 
these more pragmatic governmental and military endeavors, the blueprint also recommends a "revolution in conscience" and reminds policymakers that religious institutions and religious leaders can "provide timely warning about threats in remote areas...and can act as catalysts for preventive action in their communities. ${ }^{35}$ There is no mention of museums or of Holocaust museums in the blueprint, but as will be demonstrated later in this chapter, Holocaust museums today—especially the Holocaust Memorial Museum — are clearly participating in what could be called the attempt to create a "revolution in conscience."

To this end, on October 5, 2011 the Holocaust Memorial Museum published a report, Developing A Public Early Warning System for Genocide and Mass Killing, that summarizes the findings of the museum's Sudikoff Annual Interdisciplinary Seminar on Genocide Prevention. ${ }^{36}$ Seminar participants included Michael Abramowitz of the Holocaust Memorial Museum's Committee on Conscience, Roberta Cohen of the Brookings Institution, John McLaughlin of Johns Hopkins University and the Former Deputy Director and Former Acting Director of Central Intelligence, and genocide scholar Benjamin Valentino of Dartmouth College. The official report indicates that "participants discussed the need for [an early warning system], investigated how the system might be structured, and identified the key costs and challenges of creating and maintaining the system. ${ }^{37}$ The need for such an early warning system remains because, as the scholar of peace and conflict studies Alex Bellamy explains, even though there is international, legal consensus that it is wrong to kill innocent, non-combatant civilians and that genocide is wrong and should be prevented, "mass killing remain[s] a recurrent 
feature of world politics, sometimes perpetrators avoid punishment...civilian immunity sometimes fails to inhibit behavior and...perpetrators are able to secure sufficient legitimacy. ${ }^{, 38}$ Despite efforts to the contrary, genocide persists and its perpetrators often escape punishment, often because the perpetrators are seen as legitimate authorities who challenge social norms or deny that they are being violated. ${ }^{39}$ Israel Charny, the renown genocide scholar and Director of the Institute on the Holocaust and Genocide, Jerusalem, writes poignantly about the persistence of genocide. He states,

since life makes no sense to me unless it is for serving life, beginning with my own safety and health and also the safety and health of others, I am happy and devotedly committed to advancing efforts (my own as well as those of others) to work toward genocide prevention. Even though we are not going to make it [prevent genocide] in our time, or perhaps ever, this is the only way I want to live and die. ${ }^{40}$

His view here is startling: a preeminent scholar in the field writing that he does not think that a way to prevent genocide could ever be found in his lifetime — or even at all— though it is still worth trying. Charny does explain in his article that he thinks that genocide can be "stopped to a significant extent" if there were to be an "International Peace Army (IPA) sponsored by a world government that operates rationally, based on verified news reports and scientific assessments of risks to human lives...[that would] respond to reports of the beginning of mass murders or gathering threats of imminent mass murder and would move rapidly and promptly to the scene," but he does not think that the world is ready to commit to the creation of such an army; it is still too immoral and too power-hungry. ${ }^{41}$ Charny is not alone in feeling both cynical about the possibility of stopping genocide and certain about ways to stop it. Dr. Denis Mukwege, the Medical 
Director at the Panzi Hospital in the Congo where he and his staff treat women who are victims of sexual violence wrote in a letter published on Nicolas Kristof's New York Times blog on November 2, 2013: "We do not need more proof of what is happening, we need action to stop it, action to arrest those responsible for these crimes against humanity and to bring them to justice. We need unanimous condemnation of the rebel groups who are responsible for these acts, and we need concrete action with regard to member states of the United Nations who support these barbarities from near or afar." ${ }^{, 42}$ Mukwege and Charny both underscore the need for a unified, action-based approach to genocide prevention that can address genocidal action or the threat of such action in situ, not from afar. Holocaust museums can provide genocide education, but they are not equipped as genocide prevention organizations that can provide in situ military or humanitarian aid. What they can do is serve as a catalyst for action.

On April 23, 2012 the Holocaust Memorial Museum hosted United States President Barack Obama when he chose the museum as the location for his speech on preventing mass atrocities that announced the creation of a new Atrocities Prevention Board. In his speech, the President spoke not only about his administration's work toward the goal of genocide prevention but also about Israel and anti-Semitism. He said, “....anti-Semitism has no place in a civilized world...so when efforts are made to equate Zionism to racism, we reject them. When international fora single out Israel with unfair resolutions, we vote against them. When attempts are made to delegitimize the state of Israel, we oppose them. When faced with a regime that threatens global security and denies the Holocaust and threatens to destroy Israel, the United States will do everything in our power to 
prevent Iran from getting a nuclear weapon. ${ }^{, 43}$ Given the Holocaust Memorial Museum's commitment not only to the Holocaust but also to providing information about other genocides, the decision to deliver this speech at the museum is a logical one, though as will be discussed later in this chapter, the museum does not offer much comment on anti-Semitism today except at the very end of the two non-permanent exhibitions on its basement level, as mentioned earlier. Obama also acknowledges that the rallying cry of the post-Holocaust era, "Never Again," has not prevented the deaths of thousands of innocent people.

In addition to the blueprint and Obama's speech, in July of 2012 the museum hosted a conference, Imagine the Unimaginable: Ending Genocide in the $21^{\text {st }}$ Century, at which the hallmark events were Madeleine Albright and Ambassador Richard S. Williamson's talk, "The United States at R2P: From Words to Action,",44 the release of poll results on "US Attitudes and Awareness of Genocide;" and former Secretary of State Hillary Rodham Clinton's keynote address. Albright and Williamson, a diplomat, lawyer, and senior fellow at the Chicago Council of Global Affairs, spoke about how R2P has been applied and how its norms could function better in the international community. On the following day, the market research and consulting firm Penn Shoen Berland presented the results of it poll, with its CEO Mark Penn leading the discussion. The poll's driving question had been "What inspires people to take action against genocide and under what circumstances should the US engage to prevent it?" Conducted between June $30^{\text {th }}$ and July $10^{\text {th }}, 2012$ from telephone interviews with 1000 Americans selected at random from the general population, the poll's results included information such as: nearly one in two 
Americans are able to define the term genocide correctly, the majority of those polled are concerned about genocide because of moral principles and sympathy for the victims, and the majority are familiar with seven of eight twentieth-century genocides- the exception being the Armenian genocide. ${ }^{45}$ Its key findings reveal that Americans think that genocide is preventable, that the US plays a serious role in stopping it but that international bodies bear an even greater responsibility, and that the US should be involved in Syria along with a coalition. They also feel that military intervention, tolerance education, and arrests are the most effective ways to prevent or stop genocide. In her keynote speech at the event, Secretary Clinton notes what she says the museum does "so well...it brings us face to face with a terrible chapter in human history and it invites us to reflect on what that history tells us and how that history should guide our

path forward,"46 and she thanks the museum's Committee on Conscience for "bringing attention to contemporary cases of extreme violence against civilians." Despite complimenting the museum here, Clinton also states that "despite all we have learned and accomplished in the last 70 years, 'never again' remains an unmet, urgent goal" and categorizes the need to confront the problem of ongoing genocide in terms of moral obligation.

\section{The Los Angeles Museum of the Holocaust: Conflict Over Armenia}

Another Holocaust Museum in the United States that speaks to the subject of the place of modern genocide in Holocaust museums is the Los Angeles Museum of the Holocaust. As described earlier, the Los Angeles Museum does include a brief exhibit on modern genocide at the end of its permanent exhibition space. The exhibit consists of four 
pictures, one each of the genocides in Armenia, Rwanda, Cambodia, and Darfur and a panel printed with Lemkin's definition of genocide. The museum's audio guide offers a bit more information about each genocide, and it repeats Lemkin's definition, but there is no mention of genocides other than the Holocaust elsewhere in the museum, and the subject was not addressed at either of the museum's previous locations. Former museum Executive Director Mark Rothman explained that the museum "was always dedicated to the history of the Holocaust, its precursors, and its aftermath" and that it had never included information on modern genocide because "it shares urban space with the Museum of Tolerance and [because not mentioning] modern genocide fits organically with its mission." Rothman also identified what he called "a little bit of a shift" in thinking that contributed to the museum's decision to include information about modern genocide in its new location. He said that this "shift in inclusiveness" is "based on the intellectual principle that the Holocaust defined the subject or idea of modern genocide." Rothman added that “Lemkin's definition of genocide was based on the Armenian genocide, and his publication came out at the height of the Holocaust. ${ }^{47}$ He [Lemkin] was Jewish, and he was informed by the Holocaust. You wouldn't have a concept of modern genocide without the Holocaust." Shoenberg explained that he did not want an exhibit on modern genocide to be located at the end of the museum, where it would be the final note upon with the visitor experience would rest, but he did want to provide a moment in the museum for "compare and contrast" so that visitors could contextualize the Holocaust in world history. ${ }^{48}$ 
When asked whether the LAMH had seen any reaction or backlash from the Armenian community about the way in which the subject is presented, Rothman said no, but he did add that there had been a significant reaction from the Turkish government. Rothman explained that when the museum created a Garden of the Righteous, it invited the relevant countries each to sponsor the planting of a tree in the garden to honor its righteousness during the Holocaust. Turkey sponsored a tree, and as Rothman explained, "it was a positive relationship until they heard the audioguide [description of the Armenian genocide] and got very unhappy." In response to the Turkish government's consternation over the museum's use of the term "genocide," the museum agreed to rewrite the audio guide's text on the subject to place the genocide "in a larger context." The museum's current Acting Executive Director E. Randol Schoeberg explained, "We met with the Turkish consul and made some very minor edits to the audio guide in response to his concerns. But the text essentially remained the same."49 The museum's audio guide has since described the events of 1915 in the Ottoman Empire without using the word "genocide." The text reads in part:

the overall result of the conflict was a catastrophe for the Armenians. The total number of Armenians killed is widely disputed. Armenians believe that upwards of 1.5 million were killed while The Republic of Turkey estimates the total to be 300,000 . Several senior Ottoman officials were put on trial in Turkey in 1919-20 in connection with atrocities during the Armenian conflict. ${ }^{50}$

In the same exhibition's introductory audio text, however, the narrator states: "Only two decades before the Nazis began their extermination of the Jews, as many as 1.5 million Armenians died in an internal conflict in the Ottoman Empire that many people consider 
a genocide." ${ }^{51}$ It is surprising that the Armenian community has not objected more strongly to the museum's description and lack of use of the term genocide given that there is such strong opposition amongst Armenians to Turkish denial. For example, in his July 19, 2013 New York Times Op-Ed “Turkey’s Human Rights Hypocrisy,” Armenian Genocide scholar Taner Akçam ${ }^{52}$ wrote about the hypocrisy of Turkey's calling the civilian massacres in Syria "attempted genocide." He writes, “Turkey's desire to champion human rights in [the Middle East] is a welcome development, but...as long as Turkey continues to deny crimes committed against non-Turks in the early 1900s...its calls for freedom, justice and humanitarian values will ring false." ${ }^{, 53}$ Even one hundred years after the genocide, its denial still raises the ire of scholars, Armenians, and human rights activists; to this day the Turkish government denies that a genocide took place against the Armenians and dismisses all evidence to the contrary. Despite this knowledge, the Los Angeles museum only hints at the idea that "some" consider the "atrocity" a genocide, and after the rewriting of the audioguide text, Turkey did not withdraw its sponsorship of the tree or respond to the museum negatively in any other way.

In addition to the small exhibit on modern genocide, the Los Angeles Museum's Education Director Ilaria Benzoni-Clark explained that during the 2011-2012 school year the museum is experimenting with talking about modern genocide on its high school tours. She wrote via email, "We have also just introduced a genocide piece to our high school tour, where students reflect upon the definition of genocide and what motivated its inception. They also discuss contemporary genocide and steps they could take to get 
involved. This new piece has not yet been implemented but new docents have been trained to incorporate it in their tours. We will evaluate it this year and see how it fits in our current tours. ${ }^{, 54}$ Since that time, no major changes to the school tours have taken place.

One other way that the museum addresses the subject of modern genocide is through its monthly lecture series entitled "Let's Talk About It: New Conversations on the Holocaust." On January 6, 2012, the museum hosted Dr. Beth Meyerowitz, Professor of Psychology and Preventive Medicine at the University of Southern California, who studies Rwandan genocide survivors. Including Dr. Myerowitz in the lecture series represents an attempt to explore contemporary genocide within the context of the museum; that said, one lecture does not represent what could be called a major commitment to the subject or a concerted effort to attract an audience interested in genocides other than the Holocaust. This incorporation of the subject of modern genocide into the docent-led tours, the inclusion of the subject in a lecture series that is in name about the Holocaust, and the presence of a small exhibit in the permanent exhibition simply represents a cautious, limited effort to acknowledge that there have been genocides before and since the Holocaust. These efforts, even combined, do not affect the general mission of the museum, to provide education about and memorialization of the Holocaust.

Unlike the other museums discussed in this section, The Los Angeles Museum of the Holocaust does not employ the broad language of tolerance and understanding that so 
many of its peers do. Its mission statement calls for Holocaust commemoration and education — nothing more. While it does acknowledge other genocides in a small exhibition, as described in Chapter One, the Los Angeles museum cannot be accused of relativizing or Americanizing the Holocaust based on this one nod to modern genocide. In fact, the museum's architectural motifs, exhibitions, and mission are all distinctly in keeping with the traditional, respectful aesthetic and philosophical tropes of the Holocaust as a genre despite its innovations. The museum's website even claims that the Holocaust is "the most tragic event in human history," made explicitly in the museum itself nor made easily accessible on the website.

In the end, there are a number of reasons why the Los Angeles has chosen not to employ a broader terminology or focus more than it does on other genocides. First, the museum is located but a few miles from its theoretical competitor, the Museum of Tolerance, which is highly focused on notions of tolerance and understanding and addresses extensively the subject of other atrocities in world history. Second, the museum's current iteration reflects the focus and mission that it has had since its inception, so it is even now staying true to its roots, so to speak. Third, it seems to want to evoke the Jewish nature of the Holocaust with special care and attention. The museum's decision to place a mezuzah on every doorpost demonstrates that it wants to be understood as a Jewish place from the moment one crosses its threshold, as demonstrated in its exhibition space entitled "The World That Was," which is devoted to the task of depicting Jewish life before the Holocaust. (Certain Holocaust museums, such as the Museum of Tolerance and the Virginia Holocaust Museum, have no such exhibition whatsoever.) Finally, the Los Angeles museum is located on a small plot of land, and its interior space is much 
smaller than the Holocaust museums found in other major and even minor cities. These space constraints place a physical limit on the museum's narrative and force museum leaders to limit the scope of materials to include in its permanent exhibitions. What remains to be seen is how this museum, whose mission speaks only to the Holocaust and which argues that the Holocaust is the most tragic event in world history will evolve, especially as its museological brethren around the country make very different decisions.

\section{The Illinois Holocaust Museum \& Education Center: Remaining Relevant}

When the Illinois Holocaust Museum \& Education Center was still very much in its planning stages, museum staff members met with community leaders in and around Chicago and museum professionals across the country to ask them what they thought a twenty-first century Holocaust museum should be. The Illinois museum staff knew that they wanted the Holocaust to be the core of the museum, but they also felt that they had to address the subjects of modern genocide and human rights in order to remain relevant —a feeling that the leaders with whom they met consistently corroborated. As Richard Hirschhaut, the museum's executive director, explained, the staff and the survivors involved in the planning process wanted to "create contemporary relevance through other genocides [without becoming] a genocide museum," ${ }^{, 56}$ a museum that focused more on the subject of genocide than on the Holocaust. Hirschhaut said that while this subject "could have been an area of concern," it was not, because "the survivors were aligned with the idea of the Holocaust and connecting it with genocides that have followed and preceded. ${ }^{357}$ In addition, in 2005 the Illinois state mandate on Holocaust education underwent an amendment to include the study of genocide as well, so the new mandate influenced how the museum proceeded in regard to genocide 
education. Museum staff report that in recent years, teachers at the high school level have increased demand for genocide education, explaining that when they teach about the Holocaust, their students ask them questions about Darfur and Rwanda that they find difficult to answer. Like the Los Angeles Museum, though, the Illinois Museum prioritizes Holocaust commemoration and remembrance, but it also identifies broader goals that involve translating Holocaust history into "universal lessons" that work against "hatred, prejudice, and indifference." It also strives to provide programming that will "foster the promotion of human rights and the elimination of genocide." These are indeed lofty goals, so how will the museum accomplish them, and by what means?

Kelley Szany, the museum's Associate Director of Education \& Genocide Initiatives, explains that while the museum does not make policy—it raises awareness and provides education - it does have the responsibility to educate the public on the history of genocide, early warning system strategies, and the definition of genocide in the interest of creating a "durable," educated community. The museum wants to accomplish more than just reacting to other genocides during genocide awareness month or worse- once a genocide has begun and the killing has already begun to take place. It wants to take proactive steps. Szany acknowledged that as a Holocaust museum, there is a struggle to balance the museum's identity while making such a serious commitment to modern genocide education, especially in light of recent scholarly concerns about diluting or universalizing the Holocaust. In its genocide education programs, the museum does not, however, make comparisons between the Holocaust and other genocides; it teaches about behaviors, history, facts, and patterns. As Szany said, the key for the museum is to 
communicate to its audience that it is always vigilant in regard to genocide and that it continues to be a proactive not reactive institution. To this end, the museum prides itself on having good relationships with Chicago-area Armenian, Sudanese, and Cambodian communities to name a few, and it has the full support of the superintendent of the Chicago archdiocese in regard to Holocaust education for Catholic students and teachers alike. The museum strives to continue to foster these relationships and to continue to partner with other cultural museums and centers in the area. Szany's hope for the museum's future is that it will become more of a national voice or leader and that it becomes seen as an institution that is maintaining well the balance between education about the Holocaust and education about other genocides. The Board and leadership of the museum share these goals for the most part, but one stumbling block to the museum's achieving the balance described above is that public programming on modern genocide is not as robust it could be. Given how few traveling exhibitions exist on the subject of modern genocide, how difficult it can be to attract to them a wide audience, and how resistant the Board can be to exhibitions about violence to women, a common event in modern genocide and thus a common topic especially of photographic exhibitions on modern genocide, a museum cannot rely solely on external sources if it is seriously committed to modern genocide education. The Board of the museum rejected, for example, the proposal to bring to the museum a photo exhibition about Rwandan children born of rape. It has supported, though, the museum's partnering with Chicago's National Museum of Mexican Art for a film screening of Granito: How to Nail a Dictator, a film about the genocide of almost 200,000 Mayans in Guatemala in the 1980s. 
In the past, the museum worked to accomplish its goals by focusing on education reform in the state of Illinois. It takes pride in its passage of the Holocaust Education Mandate, in 1990, when Illinois became the first state to require Holocaust Education in public schools, and in its 2005 expansion of this mandate to create the Holocaust and Genocide Education Mandate, which requires Illinois schools to teach about all genocides. ${ }^{58}$ The museum also holds a yearly student essay contest in which high school students highlight an individual whose actions were a positive contribution during a genocide, describe a situation in which the student took a stand against bullying, or explain how the student acted as an upstander. In addition, the museum hosts yearly Student Leadership Days in which nominated, accepted high school students participate. The program is designed "to increase awareness and knowledge of the Holocaust and genocide and to challenge participants to think about lessons that can be learned from the past," with the goal being that "students will learn strategies for raising awareness of genocide, engaging in activities that promote global understanding [and]... learn to use their voices to take a stand against prejudice and indifference." The intention is that the students' participation will underscore the idea that citizens of any age can play a role in combating prejudice and indifference. ${ }^{59}$ In that interest, the program — and one like it designed for slightly younger students—-features Holocaust education, Holocaust survivor speakers, and keynote speakers such as Carl Hobert, Founder and Executive Director of the Axis of Hope Center for International Conflict Prevention in Boston, MA, Emmanuel Habimana, a child survivor of the Rwandan genocide who is active in Rwanda assisting other survivors, and Dr. Mukesh Kapila, the former head of the United Nations in Sudan. For teachers, the museum offers summer institutes on teaching the Holocaust and on teaching 
"Genocide \& Human Rights," but they must have completed the museum's Holocaust education institute in order to participate in the Genocide \& Human Rights Institute. Teachers can also borrow "Teaching Trunks" from the museum, choosing between various topics as they are indicated to be appropriate for certain age groups. All of the trunks offer Holocaust education materials, and there is a new trunk designed for secondary educators called "On Our Watch: Genocide and Human Rights."

The museum's permanent exhibition focuses exclusively on the Holocaust, with the exception that it mentions other genocides in the film that concludes one's tour of the permanent exhibition. Early in the film, narrator Barbra Streisand explains that while there were other genocides before the Holocaust - mentioning the Armenian genocide by name here- "mechanized murder" had not previously take place on the scale that it did during the Holocaust, and a Holocaust survivor states that "the Holocaust specifically is a Jewish story, but genocide, genocide is a world-wide story." Later in the film, the genocide in Bosnia is mentioned on two occasions as the narrator explains again that "genocide is a world-wide story." The Rwandan genocide receives the most extensive amount of coverage in the film, as interviews with Carl Wilkins ${ }^{61}$ and Clemantine Wamariya ${ }^{62}$ comprise several minutes of footage. Wilkins, a middle-aged white man who was the only United States citizen to remain in Rwanda during the genocide, tells the audience, "Genocide stems from the kind of thinking [that says] 'My world would be better without you in it." Wamariya, an African-American woman in her mid-twenties, speaks softly and gently about her experiences during the Rwandan genocide and about her hopes for the future. The film ends with the question, "How do we take this 
knowledge [about genocide] and turn it into action?" and then the phrase "Now it's up to you" appears in white across the now-dark screen. The implication is clear: now that one has been through the museum, learned about the Holocaust, and come to understand that there are and have been other genocides, one must take action. What kind of action or how to take action is not delineated, however. The message is that every human being has personal responsibility for violence prevention and that single voices taken together can be quite powerful and quite capable of bringing about change.

The subject of modern genocide is raised in only one other place in the museum: on the second floor in a gallery space called the "Legacy of Absence Gallery," which is devoted exclusively to exhibiting contemporary artistic responses to genocides and other atrocities. The museum's Legacy of Absence gallery on its second floor exhibits contemporary artists' responses to genocides and other atrocities, including Cambodia, Rwanda, Argentina, and the Soviet Gulag. The hope here is that the exhibition will bring attention to other genocides and attract audiences interested in contemporary art. Museum staffers are proud that the Illinois museum is the only Holocaust museum in the United States to have a contemporary art gallery, and they feel that this gallery makes them unique. Its curator is Clifford Chanin, who is currently the education director of the 9/11 Memorial Museum but continues to assist the Illinois museum with curating Legacy of Absence. In 2014, the exhibition will undergo some changes, maintaining the same themes but having a different outward appearance. Chief Curator of Collections and Exhibitions Arielle Weininger would also like the museum to develop an exhibit on the Armenian genocide in time for the $100^{\text {th }}$ anniversary of the atrocity in 2015 , but she 
explained that because no such exhibit exists at another institution, the museum would have to self-generate the exhibition. Limitations of staff, time, and funding could therefore render this exhibition nearly impossible to create.

In conclusion: all of the partnerships, exhibitions, and educational programming described here give evidence of the Illinois museum's concerted effort to promote genocide awareness, and when examined in the aggregate, they do suggest a Holocaust museum that is stretching beyond the boundaries of Holocaust information and education and toward a multi-cultural, human rights-oriented place in the Chicago cultural arena. There is a distinction to be made here, however, between the impression that the secondary and tertiary offerings of the museum gives - traveling exhibitions being secondary, for example, and a partnership or leadership day being tertiary—and the impression that the museum's primary offerings give. The primary offerings of the museum are comprised of the permanent exhibition and, at least for now, live survivor testimonies. Despite the existence of secondary and tertiary layers attentive to human rights and genocide education, the presence of the museum's closing film on modern genocide, and the Legacy of Absence gallery, the museum's overwhelming impression has only to do with the Holocaust. The dark and foreboding entrance, the extensive use of haunting survivor testimony, the intimate and unusual artifacts, and the brutalist architecture: they leave the visitor unable to escape the history, the memories, and the shadows of yesteryear. Given that the overwhelming majority of its visitors will never experience the secondary or tertiary offerings, it is in the layer of primary offerings that 
the real identity of the museum lies, therefore there is no doubt: this is a museum of the Holocaust.

\section{Conclusion}

Given this discussion of how Holocaust museums address the subject of modern genocide, it bears noting that the idea of addressing the subject of international human rights in general is not particular only to Holocaust museums. ${ }^{63}$ International human rights law scholar Jennifer Orange and museologist Jennifer Carter write in their article for Curator that museums around the world are "responding to an evolving human rights culture through their missions, exhibitions, and programming initiatives" and that this "new museology" is designed "to [intervene] in order to reclaim or safeguard universal human rights. ${ }^{, 64}$ Museums such as the District Six Museum in Cape Town, South Africa; the International Slavery Museum in Liverpool, England; the National Underground Railroad Freedom Center in Cincinnati, Ohio; and the Kigali Memorial Museum in Kigali, Rwanda are but a few of the museums that are participating in this museology of human rights. These museums and others, including Holocaust museums, are trying to influence visitors' knowledge base regarding human rights and human rights violations, and they are trying to move visitors from apathy or ignorance to action. According to Orange and Carter, however, museums on the whole have not yet perfected the art of measuring the effectiveness of their human rights-oriented exhibitions and programming, leaving a dearth of information even from museums that do implement a museology of human rights. Orange and Carter encourage museums to partner with established human rights organizations in order to evaluate whether the new museologies 
that they employ are producing the desired results and to use multiple means of engaging visitors.

There are several reasons why Holocaust museums in the United States have not engaged in the more extensive exhibitions and programming and in the creation of partnerships, as Orange and Carter recommend. First, because all Holocaust museums are limited financially to varying degrees, there is always the consideration to be made of how to allocate valuable resources. Typically those resources not needed for overhead costs are given to Holocaust-specific exhibitions: reference here the Los Angeles Museum of the Holocaust's small modern genocide exhibit buts its large, expensive Tree of Testimony and related partnership with the Shoah Foundation as one example. Only a museum as well-funded as the United States Holocaust Memorial Museum with an entirely separate branch devoted specifically to the subject of modern genocide can create an exhibition as large as From Memory to Action and host conferences and speakers of the type and scope that the Holocaust Memorial Museum does.

Despite these efforts, however, and the efforts of the museum in regard to Holocaust education, it still draws criticism today. Almost exactly twenty years after its founding, on the occasion of the twentieth anniversary of the Holocaust Memorial Museum, the Editorial Board of the Washington Post published a piece that challenged the museum on the issue of genocide prevention and on the museum's effectiveness in that regard. The piece reads, "You could look at the Rwanda genocide of 1994, the terrible killings in Darfur, Syrian dictator Bashar al-Assad's ongoing slaughter of his own people-a slaughter that the United States is doing little to prevent - and conclude that the museum 
has failed at its second mission. A fairer reading would be: There's still a lot of work to do. ${ }^{.65}$ While there is truth in this statement, that the museum has not prevented future genocides and that there is still much work to be done to prevent genocide, ${ }^{66}$ there is a better truth to be had from the Post's observations. That truth is: that not even a 265,000 square-foot museum located in the capital city of the United States of America that required over 168 million dollars to be built, that has attracted over thirty million visitors since it opened, that has what is arguably the most powerful permanent Holocaust exhibition in the world, that has extensive resources and programming, and that has an entire separate branch devoted exclusively to addressing the subject of genocide can prevent genocide. Given that this is true, then it is worth considering: if the Holocaust museum cannot prevent genocide, then what role will it have in the future aside from continued Holocaust memorialization?

\footnotetext{
${ }^{1}$ Editorial Board, "Unfinished Business at the Holocaust Museum," Washington Post, April 24, 2013.

2 Diana Jean Schemo, "Holocaust Museum Hailed as Sacred Debt to Dead," New York Times, April 23, 1993.

${ }^{3}$ Schemo, "Holocaust Museum," New York Times, April 23, 1993.

${ }^{4}$ Schemo, "Holocaust Museum," New York Times, April 23, 1993.

${ }^{5}$ Linenthal, Preserving Memory, 229.

${ }^{6}$ Linenthal, Preserving Memory, 229.

${ }^{7}$ Linenthal, Preserving Memory, 231.

${ }^{8}$ Linenthal, Preserving Memory, 229.

${ }^{9}$ Linenthal, Preserving Memory, 232.

${ }^{10}$ Linenthal, Preserving Memory, 232.

${ }^{11}$ Linenthal, Preserving Memory, 235.

${ }^{12}$ Linenthal, Preserving Memory, 235.

${ }^{13}$ Jeffrey Karl Ochsner, "Understanding the Holocaust through the U.S. Holocaust Memorial Museum," Journal of Architectural Education, Vol. 48, No. 4 (May, 1995): 242.
} 
${ }^{14}$ Elizabeth Ellsworth, "The U.S. Holocaust Museum as a Scene of Pedagogical Address," symplokē, Vol. 10, No. 1/2, The Sites of Pedagogy (2002): 25.

15 "About the Center for the Prevention of Genocide," United States Holocaust Memorial Museum, accessed September 5, 2013, http://www.ushmm.org/genocide/about/.

${ }^{16}$ Ingeborg Grosser Mauksch Obituary," accessed August 23, 2013, http://www.obitsforlife.com/obituary/379725/Mauksch-Ingeborg.php.

17 Archivist Object ID number: 2006.024/bx. 1. Institutional Archives: Box 1. Committee on Conscience: Records Re: Establishing the Committee, 1980 \& 19971998. Folder: Committee on Conscience Exploratory Committee 1980 Miscellaneous. Minutes of the Meeting of the United States Holocaust Memorial Council, Dec 10, 1980.

${ }^{18}$ Archivist Object ID number: 2006.024/bx. 1. Institutional Archives: Box 1. Committee on Conscience: Records Re: Establishing the Committee, 1980 \& 19971998. Folder: Conscience Meeting July 23, 1980.

19 "Hyman Bookbinder, Colorful Advocate for Jewish Causes, Dies at 95," The Washington Post, accessed August 23, 2013, http://articles.washingtonpost.com/2011-0722/local/35267083 1 honor-holocaust-victims-civil-rights-jewish-issues.

20 From USHMM Institutional Archives: Box 1, Committee on Conscience: Records Re: meetings of the 'Ad Hoc Exploratory Group on the Committee on Conscience.' Dec. 1993-Oct. 1994. Archivist's Object ID No. 2003.193/bx. 1. Folder called Ad Hoc Exploratory Group 5/24/1994, in a meeting of the group at USHMM on that date (41). ${ }^{21}$ Archivist Object ID number: 2006.024/bx. 1. Institutional Archives: Box 1. Committee on Conscience: Records Re: Establishing the Committee, 1980 \& 19971998. Folder: Conscience Meeting, November 19, 1980.

22 Jackie Scutari, e-mail to the author, May 28, 2013.

23 Jackie Scutari, e-mail to the author, May 28, 2013.

24 "About the Installation," United States Holocaust Memorial Museum, accessed September 5, 2013, http://www.ushmm.org/genocide/take_action/installation.

${ }^{25}$ I took a private tour of this exhibition in early spring of 2010 with then-exhibition curator Dr. Bridget Conley-Zilkic, Project Director for the Committee on Conscience. Timothy Hensley, Director of the Virginia Holocaust Museum's Carole Weinstein Library \& Archives; Ambassador Randy Bell (ret.), President of the First Freedom Center in Richmond, Virginia; and Dr. Isabelle Kinnard Richman, then Vice President for Education at the First Freedom Center, were also present. Mr. Hensley had organized the tour in light of his role in planning a new permanent exhibition on modern genocide for the Virginia Holocaust Museum, and the tour was to be followed by a meeting with Mike Abramowitz, the Director of the Committee.

${ }^{26}$ Recent scholarship might disagree with this practice of comparison. Sheri P.

Rosenberg writes that "while many early studies have focused on comparative analysis of specific cases, an increasing number of scholars have taken the broader view of genocide as a complex and dynamic process" ("Genocide Is a Process, Not an Event," Genocide Studies and Prevention, Volume 7, Number 1, Spring 2012: 16-23). In the same volume of the journal, Rosenberg's colleague Henry C. Theriault explains, "a decade ago, scholars referred to the field as 'comparative genocide studies' and emphasized the notion that the range of cases of genocide, including the Holocaust, should be understood as part of a broad phenomenon through analysis of the similarities (and differences) 
among various cases... [but] the 'comparative' modifier has in recent years been dropped, perhaps in recognition of the broadness of the field" ("Against the Grain: Critical Reflections on the State and Future of Genocide Scholarship," Genocide Studies and Prevention, Volume 7, Number 1, Spring 2012: 123-144).

27 "Pledge Wall: About the Pledge Wall," United States Holocaust Memorial Museum, accessed September 5, 2013, http://www.ushmm.org/genocide/take_action/action/pledge\#/browse.

28 Jackie Scutari, e-mail to the author, May 28, 2013.

29 "Pledge Wall: About the Pledge Wall," United States Holocaust Memorial Museum, accessed September 5, 2013, http://www.ushmm.org/genocide/take_action/action/pledge\#/browse.

${ }^{30}$ Bridget Conley-Zilkic, "What Do You Want? On Witnessing Genocide Today," The Power of Witnessing: Reflections, Reverberations, and Trace of the Holocaust/ Trauma, Psychoanalysis, and the Living Mind, ed. Nancy R. Goodman et al. (New York and London: Routledge, 2012).

${ }^{31}$ Conley-Zilkic, "What Do You Want," 321.

32 Conley-Zilkic, "What Do You Want," 321.

${ }^{33}$ Madeleine Albright and William S. Cohen, Preventing Genocide: A Blueprint for U.S. Policymakers (The United States Holocaust Memorial Museum, The American Academy of Diplomacy, and the Endowment of the United States Institute of Peace, 2008).

${ }^{34}$ Albright and Cohen, Preventing Genocide, ix.

${ }^{35}$ Albright and Cohen, Preventing Genocide, 99-100.

${ }^{36}$ United States Holocaust Memorial Museum, Developing A Public Early Warning System for Genocide and Mass Killing, October 5, 2011, Washington, D.C.

${ }^{37}$ United States Holocaust Memorial Museum, Developing, 1.

38 Alex Bellamy, "Massacres and Morality: Mass Killing in the Age of Civilian Immunity," Human Rights Quarterly 34 (2012): 927-928.

39 Bellamy, "Massacres and Morality," 932-933.

40 Israel Charny, "Requiem for the Prevention of Genocide in Our Time: Working toward an Improbable Possibility but Not Giving Up," Genocide Studies and Prevention, Volume 7, Number 1 (Spring 2012): 119.

${ }^{41}$ Charny, "Requiem," 108-109.

${ }^{42}$ Denis Mukwege, November 2, 2012 (8:49p.m.), "Dr. Mukwege Fights Back," On the Ground, http://kristof.blogs.nytimes.com/, accessed August 20, 2013, http://kristof.blogs.nytimes.com/2012/11/02/dr-mukwege-fights-back/?_r=0.

${ }^{43}$ Obama, Barack, "Remarks at the United States Holocaust Memorial Museum on Preventing Mass Atrocities," April 23, 2012, Washington, D.C., The White House: Office of the Press Secretary, accessed September 6, 2013, http://www.whitehouse.gov/the-press-office/2012/04/23/remarks-president-united-statesholocaust-memorial-museum.

44 "R2P" is an acronym for the "historic" commitment that world leaders who attended the International Coalition for the Responsibility to Protect at the 2005 United Nations World Summit "made...to protect populations from genocide, war crimes, ethnic cleansing and crimes against humanity." (International Coalition for the Responsibility to 
Protect, http://www.responsibilitytoprotect.org/index.php/about-rtop/learn-about-rtop, accessed August 21, 2013).

${ }^{45}$ All information related to this poll can be found through Penn Schoen Berland, 1110 Vermont Ave NW, Suite 1200, Washington, D.C., 20005.

${ }^{46}$ Hillary Rodham Clinton. "Imagine the Unimaginable: Ending Genocide in the 21st Century: Keynote Address by Secretary of State Hillary Rodham Clinton," July 24, 2012, Washington, D.C., accessed September 6, 2013, http://www.ushmm.org/genocide/endgenocide/transcript/clinton.php. All citations and references to her remarks can be found here.

${ }^{47}$ Here Rothman is referring to Lemkin's 1944 book, Axis Rule in Occupied Europe. (Interview with the author, February, 2012.)

${ }^{48}$ E. Randol Schoenberg, interview with the author, June 16, 2013.

${ }^{49}$ E. Randol Schoenberg, e-mail to the author, August 20, 2013.

${ }^{50}$ Los Angeles Museum of the Holocaust audioguide text \#526, E. Randol Schoenberg, e-mail to the author, August 20, 2013.

${ }^{51}$ Los Angeles Musem of the Holocaust audioguide text \#525, E. Randol Schoenberg, email to the author, August 20, 2013.

${ }^{52}$ Akçam is the first Turkish to acknowledge publicly the Armenian Genocide, which he does in his book The Young Turks' Crime Against Humanity: The Armenian Genocide and Ethnic Cleansing in the Ottoman Empire, Princeton and Oxford: Princeton University Press, 2012. The book relies heavily on sources from the Ottoman and chronicles the history of the genocide. In the concluding chapter, Akçam writes, "I believe that regardless of how one describes it, a moral admission must be made: a recognition of the truth that a wrongful act took place, one so large and serious as to be deserving of moral opprobrium. Unless grounded on the assumption that the events of 1915 were due to morally and ethically indefensible actions of the part of the Ottoman government, no serious and productive discussion of the events in question can take place" (451). His emphasis here is on the need for Turkey to admit responsibility for its actions, actions that under no circumstances can be considered ethical. It is only after this admission that progress can be made on how Turkey should proceed in acknowledging its past, assisting survivors, and addressing its future in regard to the genocide.

${ }_{53}$ Taner Akçam, “Turkey's Human Rights Hypocrisy,” New York Times, July 19, 2012.

${ }^{54}$ Ilaria Benzoni-Clark, e-mail to the author, January 12, 2012.

55 "Museum Themes," Los Angeles Museum of the Holocaust, accessed September 4, 2013, http://www.lamoth.org/exhibitions/museum-themes/.

${ }^{56}$ Richard Hirschhaut, interview with the author, July 2, 2013.

${ }^{57}$ Richard Hirschhaut, interview with the author, July 2, 2013. In this discussion about the survivors' support for addressing other genocides in the museum, Hirschhaut explained that even more pressing than this was the idea of creating a LEED-certified museum. He described achieving this certification as an "ethical imperative" upon which everyone agreed. As a result of this commitment, the museum now has Gold status, the second-highest ranking that a LEED-certified building can have. 
58 "About the Museum: Museum History," Illinois Holocaust Museum \& Education Center," accessed September 6, 2013, http://www.ilholocaustmuseum.org/pages/about_the_museum/2.php.

59 "For $9^{\text {th }}$ to $11^{\text {th }}$ Grade," Illinois Holocaust Museum and Education Center, accessed September 6, 2013, www.ilholocaustmuseum.org/pages/for_9th_11th_grade/429.php. 60 "Trunk Focus," Illinois Holocaust Museum \& Education Center, accessed September 6, 2013, http://www.ilholocaustmuseum.org/pages/trunk_focus/303.php.

${ }^{61}$ Carl Wilkins is the former head of the Adventist Development and Relief Agency International in Rwanda and was the only American who stayed in Rwanda after the genocide there began. He is currently the head of World Outside My Shoes, an educational non-profit organization.

${ }^{62}$ Clemantine Wamariya is a Rwandan genocide survivor who was six years old when the genocide began. After living in refugee camps for six years, Wamariya and her sister settled in Chicago, where they were reunited with their parents a year later. Wamariya is a graduate of New Trier High School in Winnetka, IL, the Hotchkiss School in Lakeville, CT, and Yale University. In 2011, President Obama appointed her to the Board of the United States Holocaust Memorial Museum in Washington, D.C.

${ }^{63}$ In addition, the very idea of an international, universally accepted notion of human rights remains somewhat elusive despite efforts to the contrary such as the UN Declaration cited earlier. In his extensive, two-part work The Philosophy of Human Rights (St. Paul, Minnesota: Paragon House, 2001), the philosopher Patrick Hayden writes, "The key questions are, what constitutes an integrated definition of national interest, and what value should be placed on having an international system that acts to prevent the sort of brutal behavior we have been observing in the 1990s? These questions of course lead into order as a justification for intervention. There is a component of morality to order, after all, as well as a quasi-moral notion that imputes to great powers a responsibility to ensure a relatively orderly national system" (489). Here Hayden underscores the difficulty of creating a global, united approach to genocide prevention, and he questions what would be the value of such an effort. On the surface, prevention and intervention would appear to be moral requirements for any civilized nation, but Hayden demonstrates that the idea of "national interest" is not an inherently altruistic one, thereby making all the more challenging the task of developing a national and from international commitment to human rights.

${ }^{64}$ Jennifer A. Orange and Jennifer J. Carter, "'It's Time to Pause and Reflect': Museums and Human Rights, Curator: The Museum Journal, Volume 55, Number 3 (July 2012): 259.

${ }^{65}$ Editorial Board, "Unfinished Business at the Holocaust Museum," Washington Post, April 24, 2013.

${ }^{66}$ The New York Times columnist Nicholas D. Kristof wrote about this issue of genocide repeating itself and of how much more can be done to prevent it in his June 21, 2013 article for the same paper. In the article, "Darfur in 2013 Sounds Awfully Familiar," written from the Abgadam Refugee Camp in Chad, he writes, "it is now ten years since the Darfur genocide began, and we in the news have mostly tired of the issue. It's no longer news that the Sudanese government is slaughtering its people. Yet our silence empowers Sudan's leaders to pick up where they left off." It is against this silence that 
Kristof writes, and it is against silence that the Holocaust Memorial Museum is also working. The museum, subdued and grim though it may be, is not ultimately a quiet place. It is a place that loudly proclaims the injustices of history and that asks its visitors to be vocal about injustice too. Kristof concludes by unwittingly echoing Elie Wiesel's request to President Clinton when he writes, "In the mid-2000s, an ambitious senator from Illinois complained eloquently that the White House was too silent in the face of evil in Darfur. Is it too much to ask that President Obama recall his own words - and speak out again?" 


\section{CONCLUSIONS AND PERSPECTIVES}

The previous chapters of this dissertation have attempted to chronicle the development of post-Holocaust memorial culture in Europe and the United States with a special emphasis on the role of Holocaust museums in Jerusalem, Berlin, Washington, Chicago, and Los Angeles in instantiating Holocaust memory. Important post-Holocaust debates over the uniqueness

of the Holocaust, Holocaust memory, and museological ethics have also been traced here. An effort to delineate the museums' approaches to three particular subject areas - the imminent loss of the survivor population, modern genocide, and resurgent anti-Semitismhas also been made, and the final chapter concludes with the question of what role Holocaust museums will have in the future, aside from memorializing the Holocaust, as they try to achieve contemporary relevance.

This dissertation strives to demonstrate that Holocaust museums are not just museological places but ethical ones and that every aspect of their existence-from the artifacts they include to their architecture to how they are situated in scholarly debates - is infused with ethical adjudication. Given the thesis of this dissertation - that Holocaust museums have come to a crossroads as they face the day when there will no longer be living survivors, a world tense with genocidal activity, and a Jewish community in distress over continued, virulent anti-Semitism - it has been important to try to establish the history of postHolocaust memorial practices, an understanding of the development of Holocaust museums, and an awareness of the ethical practices of the museums. The path that Holocaust museums will take in the future is grounded in the decisions and practices of earlier 
generations and it grows out of the tremendous love and respect that museum staff, supporters, and visitors have always had for the victims and survivors of the Holocaust. It was the survivors who were the impetus for all three United States museums examined in this dissertation, and it is in their name that the future of the museums must unfold. The pages that follow here offer a concluding look at the three issues mentioned above and suggest, in the end, an ethical framework through which one might evaluate the museological trajectory of Holocaust remembrance.

\section{A Day Without Survivors}

As mentioned in earlier chapters, the three Holocaust museums examined closely in this dissertation - the United States Holocaust Memorial Museum, the Illinois Holocaust Museum \& Education Center, and the Los Angeles Museum of the Holocaust—all incorporate recorded survivor testimony and live survivor testimony into their exhibitions and programming. As the survivor population ages, there will be fewer and fewer survivors available to speak in the museums, volunteer as docents, and serve as board members. One day, there will be none. While museums will find new docents and new board members, none of them will ever be authentic, first-hand witnesses to the Holocaust who can offer poignant live testimony, and more difficult, none of them will again be amongst us, living as they do not just in service of Holocaust museums but as parents, siblings, grandparents, spouses, and friends.

Holocaust survivor Sylvia Richman of Tampa, Florida was born in Krakow, Poland in 1938. During the war she lived for a time in the Lemberg (Lvov) ghetto with her mother and father 
until her father was sent to Janowska. Richman and her mother escaped from the ghetto there together but became separated, and she (Richman) spent the next two years in a convent outside of Warsaw. She was eventually reunited with her family, and they moved to the United States. Richman feels strongly that after she and her fellow survivors are gone, children will learn about the Holocaust best from "a combination of museums and teachers." She also wants survivor testimonies to be online so that they are easily accessible around the world. Like many survivors, she believes that recording testimony is of paramount importance, especially in light of the steadily aging population. Kurt Bronner, a survivor of Bergen-Belsen who now lives in Encino, California, gives testimony regularly in the Burbank, California school system and at the University of California Los Angeles. He wants Holocaust memory to be kept alive, "that it should never happen again," but he is deeply concerned about anti-Semitism today, stating, "it's still happening; it's very hurtful for the survivors to see this going on." ${ }^{2}$ Bronner witnesses contemporary incidents of antiSemitism with particular anger and pain. The memories of his father dying in his arms in Bergen-Belsen are all too fresh, as are the memories of the day that he saw his mother for the last time, being beaten by Nazi soldiers.

Survivors like Richman, Bronner, and thousands of others have recorded their testimonies to be preserved for posterity, but it is their live witness not only to the past but to the present that carries with it a deep ethical force. Would that survivors' reactions to contemporary anti-Semitism were being recorded too, for it is from their perspective that the anger, the hurt, the fear, and the sorrow of watching history repeat itself can be best expressed. There is no way to prevent survivors from dying or to defeat the march of time, but the survivors' 
witness today can be recorded and used in Holocaust museums, and it is not. A Holocaust museum that is struggling to remain relevant might find ways to include contemporary witness, for exposing visitors to survivor testimony that specifically addresses present-day problems makes relevant not only the survivors themselves but also the work of the museum without having to rely on the often-criticized, bland platitudes of tolerance and inhumanity to create that relevance.

\section{Holocaust Museums and Genocide Today}

The concern about relevance has long existed for Holocaust museums. As mentioned, even before the Holocaust Memorial Museum opened, the planning committee wondered aloud whether anyone would actually want to visit a museum about the Holocaust, and it turned out that they did — by the hundreds of thousands per year. Since the museums' respective inceptions, the survivors' presence gave the museums relevance, for they embodied the connection between the past and the present. As museums like the Holocaust Memorial Museum added exhibitions on modern genocide and as museums like the Illinois museum and the Los Angeles museum made brief acknowledgements of the subject, modern genocide became the catalyst for relevance. It was through exhibitions on contemporary atrocities that Holocaust museums could in theory make connections between the Holocaust and other, more recent genocides, attract a slightly younger and different audience, and establish relationships with other organizations and communities. This only happened to a noticeable degree at the Holocaust Memorial Museum, not necessarily because of its exhibition From Memory to Action but because of its Committee on Conscience and that organization's accessibility to high-profile speakers and relationship with the museum. 
Indeed, at the Illinois museum and the Los Angeles museum, the subject of modern genocide is given cursory attention at best.

In addition to the lack of effectiveness described here, this reliance on modern genocide to create relevance has angered scholars who object to these exhibits on the grounds that they universalize the Holocaust. Alvin Rosenfeld argues against museums' reliance upon a broad, "inclusive" language of human rights and social justice to create meaning and relevance. ${ }^{3}$ He writes that:

Admirable in themselves, these goals originate in contemporary American social and political agendas that look to the Holocaust chiefly for pragmatic and didactic reasons, as a catalyst for moral education and social action. The idea, a recognizably American one, is to use the Nazi genocide of the Jews for programs that will derive some good from all that bad. The aim may be commendable, but in working to attain it, will the overwhelmingly destructive history of the Holocaust be accurately remembered and still at the center of concern? ${ }^{4}$

The problem that Rosenfeld identifies here is, he suggests, that the Holocaust is reduced and palliated when subsumed under the broader category of human rights and social action for the sake of remaining relevant, palatable, and attractive to visitors. Only the Los Angeles museum has emerged as a Holocaust museum that has made no such efforts at "tolerance education" and instead has focused completely on the Holocaust with no other pretense in mind. As time passes, the Los Angeles museum will demonstrate whether the Holocaust can be "accurately remembered" and internalized in the visitor for its very "destructiveness" without being overtly related to other themes, peoples, or historical events in an effort to create meaning and instantiation for visitors and longevity for the museum. 


\section{Resurgent Anti-Semitism}

For an institution like that of the Holocaust museum that seeks remembrance and contemporary relevance, one of the most ironic omissions is the lack of information presented about present-day anti-Semitism. Almost all Holocaust museums educate the visitor about anti-Semitism before and during the Holocaust, but there is no mention of whether anti-Semitism simply vanishes after the war-and it does not. Immediately after the war, as mentioned in chapter one, Jews returning from hiding and from the camps still encountered virulent anti-Semitism in the DP camps and when they tried to return to their homes. Later the Six Day War in 1967 raised concern in the Jewish community as well, but as Michael Berenbaum writes in the introduction to his book, Not Your Father's Antisemitism: Hatred of the Jews in the $21^{\text {st }}$ Century: "in the 1990s, it seemed as if peace in Israel was but a matter of time and Jews could be 'normal' people, a nation whose survival was granted and who could thrive with opportunity and without being the target of hatred. Israel was productive and prosperous, secure and stable, and Jews everywhere were experiencing the joys of freedom." This respite from chronic anxiety about Jewish survival and hatred of Jews did not last, however. As Berenbaum explains, this period of promise soon dissolved: "the peace process collapsed; the hope of Oslo was replaced by the dismal reality of Intifada II, which now seems tame in comparison to the activities of militant Islam. Antisemitism has exploded within the Muslim world...Political anti-Zionism has fueled hatred within the Arab world, and religious anti-Judaism has propelled political opposition to Israel."6 Given this stark and frightening portrayal of the vigorous resurgence of antiSemitism, it seems worth asking why Holocaust museums - museums that chronicle not only the rise of anti-Semitism in the early twentieth century but also its horrible, irreparable 
culmination in the Holocaust - would not be scrambling to make clear to visitors that the problem remains today.

As mentioned in Chapter Five, senior museum staff at the Holocaust Memorial Museum, the Los Angeles museum, and the Illinois museum all feel that the Anti-Defamation League should bear the responsibility of educating the public about anti-Semitism. No matter how successful the ADL's programming could be and no matter how extensive its online resources for teachers and community members, if the Holocaust Memorial Museum alone sees over one million visitors per year who do not receive information that anti-Semitism did not cease to exist in 1945 , then a major opportunity is lost. Visitors to Holocaust museums typically emerge from their experiences deeply affected and profoundly influenced; not educating them that the hatred to which they bore witness in the museum still exists today not only in the Arab world but in Europe means forgoing 1) the chance at contemporary relevance that museums so urgently require and 2) an opportunity to preserve the singularity of the Holocaust while creating relevance.

Why then are Holocaust museums not taking a more aggressive approach to acknowledging the problem of resurgent anti-Semitism? In discussing this issue with Michael Berenbaum in an interview on July 24, 2013, he suggested that one reason is that the human rights community is presently experiencing a crisis in regard to Israel, so the normal alliances between Jewish organizations and human rights organizations are not as strong now as in the past. The Jewish community is also divided over Israel's presence in and policies regarding the West Bank and the Gaza Strip, with some arguing that Israel is an apartheid state oppressing the Palestinians and others arguing that the Palestinians and factions within the 
Arab world must recognize Israel's right to exist within certain borders. Berenbaum pointed out that in addition to this bifurcation amongst Jews, there is another problem within the Jewish community today: a lack of investment in the Holocaust as part of Jewish life. He cites Birthright Israel, an organization that takes American Jewish college students on free trips to Israel, for not sufficiently investing in the Holocaust because students' only exposure to the Holocaust is a quick morning's visit to Yad Vashem on one day of the trip. Unlike their parents and grandparents, then, young American Jews today are not growing up with the same investment in the Holocaust as their parents and grandparents.

In an interview with Alvin Rosenfeld on May 14, 2013, he cites two more reasons for Holocaust museums' lack of attention to the subject of resurgent anti-Semitism. First Rosenfeld argues that in the United States, anti-Semitism is not a significant threat except on college campuses. A report from the ADL released on July 22, 2013 states that there were

a total of 927 anti-Semitic incidents across the U.S. in 2012 including assaults, vandalism and harassment, marking a 14 percent decline from the 1,080 incidents reported in 2011 [and that] the 2012 total included 17 physical assaults on Jewish individuals, 470 cases of harassment, threats and events, and 440 cases of vandalism. ${ }^{7}$

A decline in anti-Semitic incidents is certainly good, but there is still reason to view college campuses in the United States as worthy of serious concern about anti-Semitism there. Rosenfeld also argues that there is a problem in contemporary intellectual discourse that conversations about anti-Semitism in the Arab world are limited—in an environment in which no subject should be off-limits—and that expressing concern on the subjects merits the label of "Islamaphobe." Thoughtful scholarly discourse on resurgent anti-Semitism is thus 
lacking at the time when it is needed most, especially when the research that is being done demonstrates that, as Gunther Jikeli writes in his article "Antisemitism among Young European Muslims, ${ }^{\prime 8}$ while there are different categories of anti-Jewish hostility such as the persistence of "classic anti-Semitic attitudes" or negative opinions of Jews in regard to Israel, there is one that stands out. That category is one in which there are no specific arguments for why Jews are worthy of hostility, so "[the young people studied] reveal a normalization of negative views of Jews and show the true character of antisemitism: Jews are hated because they are Jews." ${ }^{\text {It }}$ is this kind of blind, irrational hatred, imposed unjustifiably upon Jews collectively that results in an anti-Semitism that does not, as Berenbaum writes, look like the anti-Semitism of earlier generations. It is critical for Holocaust museums to teach visitors that the forms and faces of hatred are mutable, especially in a world in which the perpetrators are not just adults but often, and unexpectedly, children.

\section{Conclusion}

Lest this chapter imply nothing but a grim future for Holocaust museums given the loss of the survivors, the seemingly irrepressible nature of genocidal activity, and the deep hatred of Jews looming over Europe and the Arab world, in conclusion I shall offer an ethical framework through which a favorable and productive future of Holocaust museums could be postulated: what might be called an ethic of attempt. Charles Mathewes writes about this particularly Jewish form of ethics in his book Understanding Religious Ethics. He writes that there is in Jewish ethics "the idea...that there is a tacit obligation to act lifnim mishurat hadin - beyond the line of the law, beyond the bare minimum. That is to say, the rabbis recognize a "morality of aspiration.",10 Holocaust museums participate in this task of 
aspiring to accomplish more than the minimum of what is required, and in so doing they engender concrete, Jewish, human imperatives. Just as the Holocaust memorial attempts to reach beyond architecture or beyond art, so do Holocaust museums strive to accomplish more than what traditional museology has required of museums. When post-Holocaust memorial practices proved insufficient and when Washington supported the idea, a major Holocaust museum in the nation's capital came into being — not a memorial or a book or a film or anything that had been done before. This was a momentous occasion, but because there had only been one Holocaust museum built in the world before that —and a small one at that, Yad Vashem-museum planners found themselves in the proverbial uncharted territory. Their strong ethic of attempt, of acting beyond what was required, led them to plan the new museum with assiduous attention to detail and to ethical nuance and with the goal of representing what many at the time argued was largely unrepresentable. Their ethic of attempt also led them to establish the precedent that Holocaust museums in the United States would not just be memorial institutions that provide a history of the Holocaust; they would also revolutionalize museum architecture, advocate for social change, represent the unthinkable, create multi-variable narratives, and, eventually, address other atrocities as well. They would chronicle the past but also serve as a prophetic voice in society, a voice with a distinctive sense of moral obligation and a keen ability to foresee future challenges. No other type of memorial—or other—museum had occupied such a place in the world before or chosen to look so far into the future to examine the issue of how the murder of innocent people could ever be stopped. The ethic of attempt demonstrated here has and will continue to prompt Holocaust museums to explore this issue, for it is unethical for them to perform the 
bare minimum, which in this case would constitute memorializing the Holocaust and only the Holocaust.

In addition, the idea of a consistent, long-term practice of attempt in relation to Holocaust museums is significant because the effects of museological memorial practice cannot be measured immediately or even quantified. The work of a Holocaust museum can take years or even decades to be manifested in a society. The question is not simply whether the museum inspires visitors to work toward genocide prevention or speak out against injustice; the question is also how the museum functions in society, in culture, in specific communities, and in the cities in which they are located. The ethic of attempt thus requires the need for patience and a willingness to pursue the cause of remembrance while holding temporarily at bay the desire for immediate answers and immediate outcomes. Implicit here is then the idea that Holocaust museums have by implication and by necessity had to decide that the moral commitment to memorialization constitutes an attempt worth the risk inherent in needing to observe the effects of the museum over time.

Finally, the ethic of attempt that informs all other aspects of the museums must also be permitted to perform its work in regard to resurgent anti-Semitism. Anti-Semitism today has pushed beyond its early forms and into new ones, fearlessly transforming itself into a globalized, multi-variable organism. As Daniel Jonah Goldhagen writes in his article "The Globalization of Anti-Semitism," today the "demonology about Jews" flows quickly in and out of Europe and the Middle East and has been "institutionalized in the United Nations and other governmental and non-governmental international institutions." ${ }^{\prime 1}$ This demonology has pushed far beyond its 1945 boundaries. If Holocaust museums are to be true to the ethic 
of attempt that has prompted them to go beyond the line of the law and that has enabled them to occupy a special place in American society as museological prophets, then the time has come to act on their moral obligation not only to the past but also to the future.

\footnotetext{
${ }^{1}$ Interview with the author, December 11, 2012.

${ }^{2}$ Interview with the author, January 16, 2013.

${ }^{3}$ Alvin Rosenfeld, The End of the Holocaust (Bloomington and Indianapolis: Indiana University Press, 2011), 247.

${ }^{4}$ Rosenfeld, A., End of the Holocaust, 247.

${ }^{5}$ Michael Berenbaum, introduction to Not Your Father's Antisemitism: Hatred of the Jews in the $21^{\text {st }}$ Century, by Michael Berenbaum (St. Paul, Minnesota: Paragon House: 2008), xix.

${ }^{6}$ Berenbaum, Not Your Father's, xix.

7 “ADL Audit," Anti-Defamation League, accessed September 11, 2013, http://www.adl.org/press-center/press-releases/anti-semitism-usa/adl-audit-us-antisemitic-incidents-declined-14-percent.html\#.UjCK1Osqhq4.

${ }^{8}$ Gunther Jikeli, "Antisemitism amoung Young European Muslims," in Resurgent Antisemitism: Global Perpectives, 267-307, ed. Alvin Rosenfeld (Bloomington and Indianapolis: Indiana University Press, 2013), 296.

${ }^{9}$ Jikeli, "Antisemitism," 296.

${ }^{10}$ Charles Mathewes, Understanding Religious Ethics (Wiley Blackwell: 2010), 46.

${ }^{11}$ Daniel Jonah Goldhagen, "The Globalization of Anti-Semitism," in Old Demons, New Debates: Anti-Semitism in the West, ed. David I. Kertzer (Holmes \& Meier Publishers, Inc.: 2005), 181.
} 


\section{BIBLIOGRAPHY}

Abelson, Kassel. "Display of a Pasul Torah in a Museum Case," The Committee on Jewish Law and Standards of the Rabbinical Assembly, June 4, 1997.

Akçam, Taner. The Young Turks' Crime Against Humanity: The Armenian Genocide and Ethnic Cleansing in the Ottoman Empire. Princeton and Oxford: Princeton University Press, 2012.

Agar, Herbert. The Saving Remnant: An Account of Jewish Survival. New York, New York: The Viking Press, 1960.

Albright, Madeleine and William S. Cohen. Preventing Genocide: A Blueprint for U.S. Policymakers. The United States Holocaust Memorial Museum, The American Academy of Diplomacy, and the Endowment of the United States Institute of Peace, 2008.

Alpers, Svetlana. "The Museum as a Way of Seeing." In Ivan Karp and Steven Levine, eds. Exhibiting Cultures: The Poetics and Politics of Museum Display, edited by Ivan Karp and Steven Levine, 25-32. Washington, D.C.: Smithsonian Institution Press, 1991.

Akcam, Taner. “Turkey’s Human Rights Hypocrisy.” New York Times, July 19, 2012.

Amishai-Maisels, Ziva. Depiction and Interpretation: The Influence of the Holocaust on the Visual Arts. Oxford: Pergamon Press, 1993.

AP. “Agency Approves Plan For Holocaust Museum.” New York Times. July 31, 1987.

AP. "Design of Holocaust Museum Unveiled.” The New York Times. May 11, 1985.

Appel, Dora. Memory Effects: The Holocaust and the Art of Secondary Witnessing. New Brunswick, New Jersey: Rutgers University Press, 2002.

Arendt, Hannah. Eichmann in Jerusalem: A Report on the Banality of Evil. New York: Viking Press, 1963.

---. Essays in Understanding 1930-1954: Formation, Exile, and Totalitarianism. New York: Schocken Books, 1994.

Assis, Yom Tov. And I Shall Dwell Among Them: Historic Synagogues of the World. Aperture Foundation, Inc, 1995.

Assman, Aleida. "Collective Memory and Cultural Identity." New German Critique, No. 65. Cultural History/ Cultural Studies (Spring- Summer, 1995): 125-33. 
Azoulay, Ariella. "With Open Doors: Museums and Historical Narratives in Israel's Public Space.” In Museum Culture: Histories Discourses Spectacles, edited by Daniel J. Sherman and Irit Rogoff, 85-109. Minneapolis: University of Minnesota Press, 1994.

Badone, Ellen and Sharon R. Roseman. Intersecting Journeys. The Anthropology of Pilgrimage and Tourism. Urbana and Chicago: University of Illinois Press, 2004.

Bartov, Omer. "Chambers of Horror: Holocaust Museums in Israel and the US." Israel Studies Volume 2, No. 2 (1997): 66-87.

Bates, Donald L. "The Age of the Line." In Lineage: The Architecture of Daniel Libeskind, edited by Elly Bloom. The Jewish Museum of Australia, 2000.

Bauer, Yehuda. American Jewry and the Holocaust: The American Joint Distribution Committee, 1939-1945. Detroit: Wayne State University Press, 1981.

---. A History of the Holocaust. New York, New York: Franklin Watts, 1982.

---. "Holocaust and Genocide: Two Concepts or Part of Each Other?" Paper presented at the International Graduate Student Conference on Holocaust and Genocide Studies at Clark University, Worcester, Massachusetts, April 23, 2009.

---. "The Holocaust, Religion and Jewish History." In Judaism in a Secular Age: An Anthology of Secular Humanistic Jewish Thought, edited by Renee Kogel and Zev Katz. Farmington Hills, MI: International Institute for Secular Humanistic Judaism, 1995.

---. The Jewish Emergence from Powerlessness. Toronto and Buffalo: Toronto University Press, 1979.

---. Out of the Ashes: The Impact of American Jews on Post-Holocaust European Jewry. Pergamon Press, 1989.

---. Rethinking the Holocaust. New Haven and London: Yale University Press, 2001.

Bauman, Zygmunt. Modernity and the Holocaust. Ithaca, New York: Cornell University Press, 1989.

Bellamy, Alex. "Massacres and Morality: Mass Killing in the Age of Civilian Immunity," Human Rights Quarterly 34 (2012) 927-958.

Benjamin, Walter. Illuminations: Essays and Reflections. New York: Harcourt, Brace \& World, 1968.

Bennett, Jill. Emphatic Vision: Affect, Trauma, and Contemporary Art. Stanford:

Stanford University Press, 2005.

Bennett, Tony. The Birth of the Museum. London: Routledge, 1995. 
Berenbaum, Michael. "The Uniqueness and Universality of the Holocaust." In A Mosaic of Victims: Non-Jews Persecuted and Murdered by the Nazis, ed. Michael Berenbaum, 20-36. New York and London: New York University Press, 1990.

---. Introduction to Not Your Father's Antisemitism: Hatred of the Jews in the $21^{\text {st }}$

Century, by Michael Berenbaum, xix. St. Paul, Minnesota: Paragon House: 2008.

---. The Vision of the Void: Theological Reflection on the Works of Elie Wiesel, Middletown, CT: Wesleyan University Press, 1979.

---. The World Must Know: The History of the Holocaust as Told in the United States Holocaust Memorial Museum. Boston, New York, Toronto, and London: Little, Brown and Company, 1993.

Bergson, Henri. Matter and Memory. New York: Cosimo Inc., 2007.

Berkovits, Eliezer. Faith After the Holocaust. New York: Ktav Publishing House, Inc., 1973.

Bernard-Donals, Michael and Richard Glejzer. Between Witness and Testimony: The Holocaust and the Limits of Representation. Albany: SUNY Press, 2001.

Biemann, Asher. Inventing New Beginnings: On the Idea of Renaissance in Modern Judaism. Stanford, California: Stanford University Press, 2009.

Blumenthal, Michael and multiple contributing authors. Discovering the Jewish Museum Berlin. Stiftung Jüdisches Museum Berlin, 2001.

Bohm-Duchen, Monica, ed. After Auschwitz: Responses to the Holocaust in Contemporary Art. London: Lund Humphries Publishers Limited, 1995.

Boym, Svetlana. The Future of Nostalgia. New York, NY: Basic Books, 2001.

---. "Nostalgia and Its Discontents." The Hedgehog Review: Critical Reflections on Contemporary Culture, Summer 2007, Vol. 9, No. 2: 7- 18.

Branham, Joan. "Mapping Tragedy in the US Holocaust Memorial Museum." In The Tragic in Architecture, edited by Richard Patterson. John Wiley \& Sons Ltd., 2000: 5459.

---. "Sacrality and Aura in the Museum: Mute Objects and Articulate Space." The Journal of the Walters Art Gallery, Vol. 52/53 (1994/1995): 33-47.

Brenner, Michael. After the Holocaust: Rebuilding Jewish Lives in Postwar Germany. Princeton, New Jersey: Princeton University Press, 1997. 
Brockhau, Gudrun. "The Emotional Legacy of the National Socialist Past in Post-War Germany," in Memory and Political Change, eds. Aleida Assman and Linda Shortt, Palgrave Macmillan: 2012.

Brody, Richard. "The Inadequacy of Berlin's 'Memorial to the Murdered Jews of Europe," July 12, 2012, http://www.newyorker.com/online/blogs/movies/2012/07/theinadequacy-of-berlins-memorial-to-the-murdered-jews-of-europe.html.

Brown, Robert McAfee. "The Holocaust as a Problem in Moral Choice," in The Dimensions of the Holocaust, Elliot Lefkovitz, ed. Evanston, Illinois: Northwestern University Press, 1977.

Burnett, Ron. Cultures of Vision: Images, Media, and the Imaginary. Bloomington: Indiana University Press, 1995.

Carrier, Peter. Holocaust Monuments and National Memory Cultures in France and Germany since 1989. New York: Berghahn Books, 2005.

Casey, Edward. Remembering: A Phenomenological Study. Bloomington and Indianapolis: Indiana University Press, 1987 and 2000.

Cassierer, Ernst. An Essay on Man. New Haven and London: Yale University Press, 1944.

Cesarani, David. 'Challenging the 'Myth of Silence': Postwar responses to the destruction of European Jewry." In After the Holocaust: Challenging the Myth of Silence, edited by David Cesarani and Eric J. Sundquist. London and New York: Routledge, 2012.

Chametzky, Peter. "Not What We Expected: the Jewish Museum Berlin in Practice." museum and society, Nov. 2008. 6(3): 216-254.

Charmé, Stuart Z. "Newly Found Jews and the Politics of Recognition." Journal of the American Academy of Religion, Vol. 80, Number 2, June 2012: 387-410.

Charny, Israel. "Requiem for the Prevention of Genocide in Our Time: Working toward an Improbable Possibility but Not Giving Up," Genocide Studies and Prevention, Volume 7, Number 1 (Spring 2012): 108-122.

Chidester, David and Edward T. Linenthal. American Sacred Space. Bloomington: Indiana University Press, 1995.

James Clifford. "Museums as Contact Zones." In Representing the Nation: A ReaderHistories, heritage and museums, edited by David Boswell et al. London and New York: Routledge, 1999.

Clinton, Hillary Rodham. Talk given at the U.S. Holocaust Memorial Museum ForwardLooking Symposium on Genocide Prevention, Washington, D.C., July 24, 2012. 
Cohen, Arthur A. and Paul Mendes-Flohr, eds. Contemporary Jewish Religious Thought: Original Essays on Critical Concepts, Movements, and Beliefs. New York, New York: The Free Press, 1987.

Cohen, Arthur A. The Tremendum: A Theological Interpretation of the Holocaust. New York, New York: Crossroad, 1988.

Cohen, Boaz. "The Children's Voice: Postwar Collection of Testimonies from Child Survivors of the Holocaust." Holocaust and Genocide Studies, Vol. 21, No. 1, Spring 2007: 73-95.

Cohen, Beth B. Case Closed: Holocaust Survivors in Postwar America. New Brunswick, New Jersey and London: Rutgers University Press, 2007.

Cohen, Erik. "Pilgrimage and Tourism: Convergence and Divergence." In Journeys to Sacred Places, edited by E.A. Morinis. Westport, Conn: Greenwood Press, 1992.

Cohen, Richard. "Self-image through Objects: Toward a Social History of Jewish Art Collecting and Jewish Museums." In The Uses of Tradition: Jewish Continuity in the Modern Era, edited by Jack Werthheimer. Cambridge, Massachusetts and London: Harvard University Press, 1992.

Cohen, Roger. "A Jewish Museum Struggles to be Born: Berlin's Efforts to Honor Lost Millions Are Mired in Dissent." New York Times. August 15, 2000.

Cole, Tim. Selling the Holocaust: From Auschwitz to Schindler-How History is Bought, Packaged, and Sold. New York: Routledge, 2000.

Coleman, Simon, and John Elsner. Pilgrimage Past and Present in the World Religions. Cambridge: Harvard University Press, 1995.

Confino, Alon. Foundational Pasts: The Holocaust as Historical Understanding. Cambridge: Cambridge University Press, 2012.

---. Germany as a Culture of Remembrance: Promises and Limits of Writing History. Chapel Hill: University of North Carolina Press, 2006.

Bridget Conley-Zilkic. "What Do You Want? On Witnessing Genocide Today." In The Power of Witnessing: Reflections, Reverberations, and Trace of the Holocaust/ Trauma, Psychoanalysis, and the Living Mind, ed. Nancy R. Goodman and Marilyn B. Myers, 319-332. New York and London: Routledge, 2012.

Cooper, John. Raphael Lemkin and the Struggle for the Genocide Convention. New York: Palgrave Macmillan, 2008.

Coser, Lewis A. Ed. Maurice Halbwachs: On Collective Memory. Chicago and London: The University of Chicago Press, 1992. 
Crane, Susan. Museums and Memory. Stanford: Stanford University Press, 2000.

---. "Memory, Distortion, and History in the Museum." History and Theory, Vol. 36, No. 4, Theme Issue 36 (Dec., 1997): 44-63.

Coser, Lewis A., trans. Maurice Halbwachs: On Collective Memory. Chicago and London: University of Chicago Press, 1992.

Crysler, Grieg and Abidin Kusno. "Angels in the Temple: The Aesthetic Construction of Citizenship at the United States Holocaust Memorial Museum." Art Journal, Vol. 56, No. 1, Aesthetics and the Body Politic (Spring, 1997): 52-64.

Dawidowicz, Lucy S. The Holocaust and the Historians. Cambridge, Massachusetts and London, England: Harvard University Press, 1981.

---. "The Holocaust as Hisotrical Record," in Dimensions of the Holocaust, Elliot Lefkovitz, ed. Evanston, Illinois: Northwestern University Press, 1977.

Dekel, Irit. "Mediated Space, Mediated Memory: New Archives at the Holocaust Memorial Berlin." On Media Memory: Collective Memory in a New Media Age, eds. Motti Neiger, Oren Meyers and Eyal Zandberg, Palgrave Macmillan: 2011.

---. Mediation at the Holocaust Memorial in Berlin. Palgrave Macmillan: 2013.

Diner, Hasia. The Jews of the United States: 1654 to 2000. Berkeley, Los Angeles, London: University of California Press, 2006.

---. We Remember with Reverence and Love: American Jews and the Myth of Silence after the Holocaust, 1945-1962. New York and London: New York University Press, 2009.

Dinnerstein, Leonard. America and the Survivors of the Holocaust. New York, New York: Columbia University Press, 1982.

Domansky, Elisabeth. "A Lost War: World War II in Postwar German Memory," in Thinking About the Holocaust: After Half a Century, ed. Alvin Rosenfeld, Bloomington and Indianapolis: Indiana University Press, 1997.

Douglas, Ana and Thomas Vogler. Witness and Memory: The Discourse of Trauma. New York and London: Routledge, 2003.

Durkheim, Emile. The Elementary Forms of Religious Life, translated by Karen E. Fields. New York: The Free Press, 1995.

Eade, John, and Michael J. Sallnow. Contesting the Sacred: The Anthropology of Christian Pilgrimage. London: Routledge, 1991. 
Eckardt, A. Roy and Alice Eckardt. Long Night's Journey into Day: Life and Faith After the Holocaust. Detroit, Michigan: Wayne State University Press, 1982.

Editorial Board. "Unfinished Business at the Holocaust Museum." Washington Post, April 24, 2013.

Editors of the $P A J$. "Berlin's New Jewish Museum: An Interview with Tom

Freudenheim." PAJ: A Journal of Performance and Art, Vol. 22, No. 2, Berlin 2000. (May, 2000): 39-47.

Edwards, Allison and Lawrence Sullivan. Stewards of the Sacred. American Association of Museums in cooperation with the Center for the Study of World Religions, Harvard University, 2004.

Eididin, Ben. Jewish Community Life in America. New York, New York: Hebrew Publishing Company, 1947.

Eisen, Robert. "Midrash in Emile Fackenheim's Holocaust Theology." The Harvard Theological Review, Vol. 96, No. 3 (Jul., 2003): 369-392.

Ellsworth, Elizabeth. "The U.S. Holocaust Museum as a Scene of Pedagogical Address." symploke, Vol. 10, No. 1/2, The Sites of Pedagogy (2002): 12-31.

Engelhardt, Isabelle. A Topography of Memory: Representations of the Holocaust at Dachau and Buchenwald in Comparison with Auschwitz, Yad Vashem, and Washington, D.C. Bruxelles: Peter Lang, 2002.

Erlanger, Steven. "Israel Dares to Recast a Story Set in Stone." New York Times, February 13, 2005.

Fackenheim, Emil L. The Jewish Return into History: Reflections in the Age of Auschwitz and a New Jerusalem. New York: Schocken Books, 1978.

---. To Mend the World. In The Holocaust: Theoretical Readings, edited by Neil Levi and Michael Rothberg, 237-240. New Brunswick, New Jersey: Rutgers University Press, 2003.

Fehrs, Jorg. Discovering the Jewish Museum Berlin. Berlin: Jüdisches Museum, 2001.

Feingold, Henry L. "Who Shall Bear Guilt for the Holocaust? The Human Dilemma." In The American Jewish Experience, edited by Jonathan D. Sarna. New York \& London: Holmes \& Meier, 1986.

Feinstein, Margarete Myers. Holocaust Survivors in Postwar Germany: 1945-1957. New York, New York: Cambridge University Press, 2010. 
---. "Jewish Women Survivors in the Displaced Persons Camps of Occupied Germany: Transmitters of the Past, Caretakers of the Present, and Builders of the Future." Shofar: An Interdisciplinary Journal of Jewish Studies, Vol. 24, Number 4, Summer 2006: 67-89.

Feinstein, Stephen. Absence/ Presence: Critical Essays on the Artistic Memory of the Holocaust. Syracuse, NY: Syracuse University Press, 2005.

---. "Witness and Legacy," Witness \& Legacy: Contemporary Art About the Holocaust, Stephen C. Feinstein, Ed. Minneapolis, Minnesota: Lerner Publications Company, 1995

Field, Cynthia R. and Nathan Glazer. The National Mall. Rethinking Washington's Monumental Core. Baltimore: Johns Hopkins University Press, 2008.

Field, Cynthia R. "When Dignity and Beauty Were the Order of the Day: The Contribution of Daniel H. Burnham." In The National Mall. Rethinking Washington's Monumental Core, edited by Nathan Glazer and Cynthia R. Field. Baltimore: Johns Hopkins University Press, 2008.

Finder, Gabriel N. "Yizkor! Commemoration of the Dead by Jewish Displaced Persons in Postwar Germany." In Between Mass Death and Individual Loss: The Place of the Dead in Twentieth-Century Germany, edited by Alon Confino, Paul Betts, and Dirk Schumann. New York and Oxford: Berghahn Books, 2008.

Fogelman, Eva. "Coping with the Psychological Aftermath of Extreme Trauma." In Life Reborn: Jewish Displaced Persons 1945-1951, Conference Proceedings, Washington, D.C. January 14-17, 2000: 92, edited by Menachem Z. Rosensaft. A project of the United States Holocaust Memorial Museum and the Second Generation Advisory Group in association with The American Jewish Joint Distribution Committee

Freed, James Ingo. “The United States Holocaust Memorial Museum.” Assemblage, No. 9 (Jun., 1989): 58-79.

Freedberg, David. The Power of Images: Studies in the History and Theory of Response. Chicago: University of Chicago Press, 1989.

Freedman, Samuel G. Jew vs. Jew: The Struggle for the Soul of American Jewry. New York, New York: Simon \& Schuster, 2000.

Friedländer, Saul. "Memory of the Shoah in Israel: Symbols, Rituals, and Ideological Polarization." In The Art of Memory: Holocaust Memorials in History, edited by James Young. The Jewish Museum, New York: Prestel, 1994.

Friese, Heidrun. Identities: Time, Difference, and Boundaries. New York and Oxford: Berghahn Books, 2002.

Gadamer, Hans-Georg. Truth and Method. London and New York: Continuum Publishing Group, 2004. 
Gay, Ruth. Safe Among the Germans: Liberated Jews After World War II. New Haven and London: Yale University Press, 2002.

---. Unfinished People: Eastern European Jews Encounter America. New York and London: W. W. Norton \& Company, 1996.

Geddes, Jennifer. "Banal Evil and Useless Knowledge: Hannah Arendt and Charlotte Delbo on Evil after the Holocaust." Hypatia vol. 18, no. 1 (Winter 2003), 104-115.

---. Evil After Postmodernism: Histories, Narratives, Ethics. London and New York: Routledge, 2001.

---. “An Interview with James E. Young." The Hedgehog Review: Critical Reflections on Contemporary Culture, "The Uses of the Past," Summer 2007, Volume Nine, Number Two, 2007: 68-72.

Geertz, Clifford. The Interpretation of Cultures. Selected Essays by Clifford Geertz. New York: Basic Books, 1973.

Genizi, Haim. American's Fair Share: The Admission of Resettlement and Displaced Persons, 1945-1952. Detroit: Wayne State University Press, 1993.

Geras, Norman. The Contract of Mutual Indifference: Political Philosophy After the Holocaust. London and New York: Verso, 1998.

Gerber, Mitchel. "Reconstituting Political Philosophy after the Holocaust: Toward the Prevention of Genocide," in The Double Binds of Ethics after the Holocaust: Salvaging the Fragments, Jennifer L. Geddes, John K. Roth, and Jules Simon, eds. Palgrave Macmillan, 2009.

Giebelhausen, Michaela. "The Architecture IS the Museum.” In New Museum Theory and Practice: An Introduction, edited by Janet Marstine. Malden, MA: Blackwell, 2006.

Giere, Jacqueline. "We're On Our Way, but We're Not in the Wilderness." In The Holocaust and History: The Known, the Unknown, the Disputed, and the Reexamined, edited by Michael Berenbaum and Abraham J. Peck. Bloomington and Indianapolis: Indiana University Press, 1998.

Giovanni, Joseph. "Design for the U.S. Holocaust Museum Is Ready." New York Times. May 21, 1987.

Gitlitz, David M. and Linda Kay Davidson. Pilgrimage and the Jews. Westport, Ct.: Praeger, 2006.

Godfrey, Mark. Abstraction and the Holocaust. New Haven: Yale University Press, 2007.

Goldberg, Harvey E. Jewish Passages: Cycles of Jewish Life. Berkeley and Los Angeles: University of California Press, 2003. 
Goldhagen, Daniel Jonah. "The Globalization of Anti-Semitism." In Old Demons, New Debates: Anti-Semitism in the West, edited by David I. Kertzer, 179-184. Holmes \& Meier Publishers, Inc.: 2005.

Goldhill, Simon. Jerusalem: City of Longing. Cambridge, Massachusetts and London, England: The Belknap Press of Harvard University Press, 2008.

Gordon, Albert I. Jews in Suburbia. Boston: Beacon Hill Press, 1959.

Goren, Arthur A. "A Golden Decade for American Jews: 1945-1955." In The American Jewish Experience, edited by Jonathan Sarna. New York and London: Holmes \& Meier, 1986.

Gottschalk, Max and Abraham G. Duker. Jews in the Post-War World. New York, New York: The Dryden Press, 1945.

Gourevitch, Philip. “Washington's Holocaust Theme Park,” Harper’s (July 1993): 56-57.

Greenberg, Irving. "Cloud of Smoke, Pillar of Fire: Judaism, Christianity, and Modernity after the Holocaust." In Auschwitz: Beginning of a New Era? Reflections on the Holocaust, edited by Eva Fleischner. New York: KTAV Publishing House, Inc., 1974.

Greenberg, Yitzchak. Judaism and Modernity: Realigning the Two Worlds. Address at the Lookstein Center for Jewish Education Principals' Seminar, 2004. Transcript edited by Zvi Grumet. Accessed September 15, 2013. http://www.targumshlishi.org/looksteinPersp2006.pdf.

Grossman, Atina. "Entangled Histories and Lost Memories: Jewish Survivors in Occupied Germany, 1945-49.” In We Are Here: New Approaches to Jewish Displaced Persons in Postwar Germany, edited by Avinoam J. Patt and Michael Berkowitz. Detroit: Wayne State University Press, 2010.

Grossman, Grace Cohen. Jewish Art. Hugh Lauter Associate, Inc.: 1995.

---. Jewish Museums of the World. Hugh Lauter Levin Associates, Inc.: 2003

Gruber, Ruth Ellen. Virtually Jewish: Reinventing Jewish Culture in Europe. Berkeley and Los Angeles: University of California Press, 2002.

Gruber, Samuel. "Jewish Identity and Modern Synagogue Architecture.” In Jewish Identity in Contemporary Architecture, edited by Angeli Sachs and Edward van Voolen Prestel-München. Berlin, London, New York: 2004.

Grunberger, Michael. From Haven to Home: 350 Years of Jewish Life in America. Library of Congress: 2004. 
Hansen, Miriam Bratu. "Schindler's List is not Shoah: Second Commandment, Popular Modernism, and Public Memory." In Visual Culture and the Holocaust, edited by Barbie Zelizer. New Brunswick: Rutgers University Press, 2000.

Hansen-Glucklich, Jennifer. "Holocaust Memories: Visuality and the Sacred in Museums and Exhibits." PhD diss., University of Virginia, 2011.

Harbison, Robert. The Built, the Unbuilt, and the Unbuildable: In Pursuit of Architectural Meaning. Cambridge, Massachusetts: The MIT Press, 1992.

Hartman, Geoffrey. Holocaust Remembrance: The Shapes of Memory. Oxford, England and Cambridge, Massachusetts: Blackwell Publishers, 1994.

---. The Longest Shadow: In the Aftermath of the Holocaust. New York: Palgrave MacMillan, 1996.

---. Scars of the Spirit: The Struggle Against Inauthenticity. Palgrave Macmillan, 2002.

Hawthorn, Jeremy. "The Face-to-Face Encounter in Holocaust Narrative." In After Testimony: The Ethics and Aesthetics of Holocaust Narrative for the Future, edited by Jakob Lothe, Susan Rubin Suleiman, and James Phelan, 143-161. Columbus, Ohio: Ohio State University Press, 2012.

Hayes, Peter. Ed. Lessons and Legacies: The Meaning of the Holocaust in a Changing World. Evanston, IL: Northwestern University Press, 1991.

Helmreich, William. Against All Odds: Holocaust Survivors and the Successful Lives They Made in America. New York, New York: Simon \& Schuster, 1992.

---. "Against All Odds: Survivors of the Holocaust and the American Experience." In The Holocaust and History: The Known, the Unknown, the Disputed, and the Reexamined, edited by Michael Berenbaum and Abraham J. Peck. Bloomington and Indianapolis: Indiana University Press, 1998.

Henry, James Pepper. "Challenges in Managing Culturally Sensitive Collections at the National Museum of the American Indian." In Stewards of the Sacred, edited by Lawrence E. Sullivan and Alison Edwards. Washington, DC: American Association of Museums, 2004: 105-112.

Hirsch, Marianne. "Surviving Images: Holocaust Photographs and the Work of Postmemory." The Yale Journal of Criticism, Vol 14, No 1 (2001): 5-37.

Hoare, Liam. "A Bittersweet Holocaust Memorial in Berlin,” The Forward, June 21, 2013, http://blods.forward..com/forward-thinking/179059/a-bittersweet-holocaustmemorial-in-berlin/.

Hobsbawm, Eric and Terence Ranger. The Invention of Tradition. Cambridge: Cambridge University Press, 1983. 
Hogan, David J. The Holocaust Chronicle: A History in Words and Pictures.

Lincolnwood, IL: Publication International, Ltd, 2003.

Hooper-Greenhill, Eilean. Museum, Media, Message. London and New York: Routledge, 1995.

---. Museums and the Interpretation of Visual Culture. London and New York: Routledge, 2000.

---. Museums and the Shaping of Knowledge. London and New York: Routledge, 1992.

Hubert, Henri, and Marcel Mauss. Sacrifice: Its Nature and Functions [1898]. Translated by W.D. Hall. Chicago: University of Chicago Press, 1964.

Hudson, Kenneth. "Attempts to Define 'Museum."' In Representing the Nation: A Reader-Histories, heritage and museums, edited by David Boswell and Jessica Evans. London and New York: Routledge, 1999.

Hutton, Patrick. History as an Art of Memory. Hanover and London: University Press of New England, 1993.

Huyssen, Andreas. Present Pasts. Urban Palimpsests and the Politics of Memory. Stanford, CA: Stanford University Press, 2003.

----. Twilight Memories: Marking Time in a Culture of Amnesia. New York: Routledge, 1995.

Hyman, Paula. "From City to Suburb: Temple Mishkan Tefila of Boston." In The American Synagogue: A Sanctuary Transformed, edited by Jack Werthimer. Cambridge: Cambridge University Press, 1987.

Jelin, Elizabeth. "The Politics of Memory: The Human Rights Movement and the Construction of Democracy in Argentina." Latin American Perspectives, Vol. 21, No. 2, Social Movements and Political Change in Latin America: 1 (Spring, 1994): 38-58.

Jencks, Charles. The Iconic Building. New York: Rizzoli Press, 2005.

---. The Language of Post-Modern Architecture. 4th edition. New York: Rizzoli, 1984.

---. Visual Culture. London: Routledge, 1995.

Jewish Museum Berlin. Discovering the Jewish Museum Berlin. Berlin: Stiftung Jüdisches Museum Berlin, 2001.

Jikeli, Gunther. "Antisemitism amoung Young European Muslims" In Resurgent Antisemitism: Global Perpectives, edited by Alvin Rosenfeld, 267-307. Bloomington and Indianapolis: Indiana University Press, 2013. 
Jockusch, Laura. "Chroniclers of Catastrophe: History Writing as a Jewish Response to Persecution Before and After the Holocaust." In Holocaust Historiography in Context: Emergence, Challenges, Polemics, \& Achievements, edited by David Bankier and Dan Michman. New York and Oxford: Berghahn Books, 2008.

---. Collect and Record!: Jewish Holocaust Documentation in Early Postwar Europe. New York, New York: Oxford University Press, 2012.

---. "A Folk Momument to Our Destruction and Heroism: Jewish Historical Commissions in the Displaced Persons Camps of Germany, Austria, and Italy." In We Are Here: New Approaches to Jewish Displaced Persons in Postwar Germany, edited by Avinoam J. Patt and Michael Berkowitz. Detroit: Wayne State University Press, 2010.

Jones, David H. Moral Responsibility in the Holocaust: A Study in the Ethics of Character. Lanham, Maryland: Rowman \& Littlefield Publishers, Inc., 1999.

Jones, Lindsay. The Hermeneutics of Sacred Architecture: Experience, Interpretation, Comparison. Cambridge: Harvard University Press, 2000.

Kaplan, Brett Ashley. Unwanted Beauty: Aesthetic Pleasure in Holocaust Representation. Urbana-Champaign: University of Illinois Press, 2007.

Katz, Steven T. The Holocaust in Historical Context: The Holocaust and Mass Death before the Modern Age, Volume I. New York and Oxford: Oxford University Press, 1994.

---. “The 'Unique' Intentionality of the Holocaust.” Modern Judaism, Vol. 1, No. 2 (Sep. 1981): 161-183.

Kee, Howard Clark. "Defining the First-Century C.E. Synagogue: Problems and Progress." In Evolution of the Synagogue: Problems and Progress, edited by Howard Clark Kee and Lynn H. Cohick. Harrisburg, PA: Trinity Press International, 1999.

Keegan, Edward. "Illinois Holocaust Museum: Chicago/ Tigerman McCurry Architects." Architect: The Magazine of the American Institute of Architects, April 6, 2010. http://www.architectmagazine.com/cultural-projects/holocaust-museum-skokieillinois.aspx.

Kelner, Shaul. Tours That Bind: Diaspora, Pilgrimage, and Israeli Birthright Tourism. New York and London: New York University Press, 2010.

Kirshenblatt-Gimblett, Barbara. Destination Culture: Tourism, Museums, and Heritage. Berkeley, Los Angeles, and London: University of California Press, 1998.

---. "Exhibitionary Complexes." In Museum Frictions: Public Cultures/Global Transformations, edited by Ivan Karp, Corinne A. Kratz, Lynn Szwaja, and Tomas Ybarra-Frausto . Durham and London: Duke University Press, 2006. 
Klein, Julia. "From the Ashes, A Jewish Museum." The American Prospect. February 12, 2001. Accessed September 15, 2013. http://prospect.org/article/ashes-jewish-museum.

Klein, Kerwin Lee. "On The Emergence of Memory in Historical Discourse." Representations 69 (Winter 2000): 127-50.

Kligerman, Eric. Sites of the Uncanny: Paul Celan, Specularity, and the Visual Arts. Berlin: Walter De Gruyter, 2007.

Koshar, Rudy. From Monuments to Traces: The Artifacts of German Memory, 18701990. Berkeley and Los Angeles: University of California Press, 2000.

Krauthammer, Charles. "Holocaust Museum.” Washington Post. April 23, 1993.

Krinsky, Carol H. Synagogues of Europe: Architecture, History, Meaning. Mineola, New York: Dover Publications, Inc. 1985.

Kristof, Nicholas D. "Darfur in 2013 Sounds Awfully Familiar." New York Times. June $21,2013$.

Kugelmass, Jack and Jonathan Boyarin. From a Ruined Garden: The Memorial Books of Polish Jewry. Indianapolis: Indiana University Press, 1998.

Ladd, Brian. The Ghosts of Berlin: Confronting German History in the Urban Landscape. Chicago: University of Chicago Press, 1997.

Lakoff, George and Mark Johnson. Metaphors We Live By. Chicago: The University of Chicago Press, 1980.

Landsberg, Alison. Prosthetic Memory: The Transformation of American Remembrance in the Age of Mass Culture. New York: Columbia University Press, 2004.

Lang, Berel. Holocaust Representation: Art Within the Limits of History and Ethics. Baltimore and London: The Johns Hopkins University Press, 2000.

---. Post-Holocaust: Interpretation, Misinterpretation, and the Claims of History. Bloomington and Indianapolis: Indiana University Press, 2005.

Laqueur, Thomas. “The Holocaust Museum.” Threepenny Review No. 56 (Winter, 1994): $30-32$.

Laub, Dori. "Testimony as Life Experience and Legacy." In The Power of Witnessing: Reflections, Reverberations, and Traces of the Holocaust, Nancy R. Goodman and Marilyn B. Meyers, eds. New York and London: Routledge, 2012.

Lavsky, Hagit. "The Experience of the Displaced Persons in Bergen-Belsen: Unique or Typical Case?" In We Are Here: New Approaches to Jewish Displaced Persons in 
Postwar Germany, edited by Avinoam J. Patt and Michael Berkowitz. Detroit: Wayne State University Press, 2010.

---. New Beginnings: Holocaust Survivors in Bergen-Belsen and the British Zone in the Germany, 1945-1950. Detroit: Wayne State University Press, 2002.

LeGoff, Jaques. History and Memory. Translated by Steven Rendall and Elizabeth Claman. New York: Columbia University Press, 1992.

Lennon, John J. and Malcolm Foley. Dark Tourism. Cengage Learning, 2010.

Levi, Neil and Michael Rothberg. The Holocaust: Theoretical Readings. New Brunswick, New Jersey: Rutgers University Press, 2003.

Levinas, Emmanuel. Totality and Infinity: An Essay on Exteriority. Translated by Alphonso Lingis. Pittsburgh, Pennsylvania: Dusquene University Press, 1969.

Levine, Lisbeth. "Skokie to Open New Holocaust Museum: Site of Neo-Nazi March That Launched Shoah Education." Forward.com. Accessed September 15, 2013, http://forward.com/articles/104682/skokie-to-open-new-holocaust-museum/.

Lewis, Michael J. "The Idea of the American Mall." In The National Mall. Rethinking Washington's Monumental Core, edited by Nathan Glazer and Cynthia R. Field. Baltimore: Johns Hopkins University Press, 2008.

Libeskind, Daniel. "Between the Lines: Extension to the Berlin Museum, With the Jewish Museum.” Assemblage, No. 12 (August, 1990): 18-57.

---. Daniel Libeskind: Radix-Matrix. Architecture and Writings. Munich: Prestel-Verlag, 1997.

---. The Space of Encounter. London: Thames \& Hudson Ltd, 2001.

Liebman, Charles S. and Eliezer Don-Yehiya. Civil Religion in Israel. Berkeley, Los Angeles, London: University of California Press, 1983.

Linenthal, Edward T. "The Boundaries of Memory: The United States Holocaust Memorial Museum.” American Quarterly Vol. 46, No. 3 (September, 1994): 406- 433.

---. "Locating Holocaust Memory: The United States Holocaust Memorial Museum." In American Sacred Space, edited by David Chidester and Edward T. Linenthal. Bloomington: Indiana University Press, 1995.

---. Preserving Memory: The Struggle to Create America's Holocaust Museum. New York: Columbia University Press, 1995.

Lipstadt, Deborah E. The American Press \& the Coming of the Holocaust 1933-1945. New York: The Free Press, 1986. 
---. "Not Facing History.” The New Republic, March 6, 1995.

Liska, Vivian. "Winged Words and Wounded Voices: Geoffrey Hartman on Midrash and Testimony." Jewish Quarterly Review (Spring 2013): 133-140.

Liss, Andrea. Trespassing Through Shadows: Memory, Photography \& the Holocaust. London \& Minneapolis: University of Minnesota Press, 1998.

Long, Rose-Carol Washton, Matthew Baigell, and Milly Heyd. Jewish Dimensions in Modern Visual Culture: anti-Semitism, assimilation, affirmation. Hanover and London: University Press of New England, 2010.

Lord, Gail Dexter and Barry Lord, Eds. The Manual of Museum Planning, $2^{\text {nd }}$ Edition. Walnut Creek, California: Altamira Press, 1999.

Maccoby, Hyam. "Anti-Judaism and Anti-Semitism." Arthur A. Cohen and Paul Mendes-Flohr, eds. In Contemporary Jewish Religious Thought: Original Essays on Critical Concepts, Movements, and Beliefs, edited by Arthur A. Cohen and Paul MendesFlohr, 14-18. New York, New York: The Free Press, 1987.

Macdonald, Sharon. The Politics of Display: Museums, Science, Culture. London and New York: Routledge, 1998.

Macdonald, Sharon and Gordon Fyfe. Theorizing Museums: Representing Identity and Diversity in a Changing World. Cambridge: Blackwell, 1996.

Magid, Shaul. "The Holocaust and Jewish Identity in America: Memory, the Unique, and the Universal." Jewish Social Studies: History, Culture, Society n.s. 18, no. 2 (Winter 2012): 100-135.

Maleuvre, Didier. Museum Memories. Stanford: Stanford University Press, 1999.

Mankowitz, Zeev W. Life Between Memory and Hope: The Survivors of the Holocaust in Occupied Germany. Cambridge, England: Cambridge University Press, 2002.

Mann, Barbara. Space and Place in Jewish Studies. New Brunswick, New Jersey, and London: Rutgers University Press, 2012.

Margalit, Avishai. The Ethics of Memory. Cambridge, Massachusetts and London, England: Harvard University Press, 2002.

Margry, Peter Jan. Shrines and Pilgrimage in the Modern World. New Itineraries into the Sacred. Amsterdam: Amsterdam University Press, 2008.

Marx, Dalia. "Memorializing the Shoah." In May God Remember: Memory and Memorializing in Judaism, edited by Rabbi Lawrence A Hoffman, Woodstock, Vermont: Jewish Lights Publishing, 2013. 
Mathewes, Charles. Understanding Religious Ethics. Wiley Blackwell: 2010.

Miller, Judith. "Holocaust Museum: A Troubled Start.” New York Times. April 22, 1990.

Milton, Sybil. In Fitting Memory: The Art and Politics of Holocaust Memorials. Detroit: Wayne State University Press, 1991.

Minow, Martha. Between Vengeance and Forgiveness: Facing History after Genocide and Mass Violence. Boston: Beacon Press, 1998.

Moore, Deborah Dash. "Jewish Migration in Postwar America: The Case of Miami and Los Angeles." In The American Jewish Experience, edited by Jonathan Sarna. New York and London: Holmes \& Meier, 1986.

---. To the Golden Cities: Pursuing the American Jewish Dream in Miami and Los Angeles. New York, New York: The Free Press, 1994.

Morgan, Michael. "Jewish Ethics after the Holocaust." Contemporary Jewish Ethics and Morality: A Reader, edited by Elliott N. Dorff and Louis Newman, 194-211. Oxford and New York: Oxford University Press, 1995.

Mostow, Peter. "'Like Building on top of Auschwitz:' One the Symbolic Meaning of Using Data from the Nazi Experiments, and on Non-Use as a Form of Memorial." Journal of Law and Religion, Vol. 10, No. 2 (1993-1994): 403-431.

Muller, Beate. "Trauma, Historiography and Polyphony: Adult Voices in the CJHC's Early Postwar Child Holocaust Testimonies." History \& Memory, Vol. 24, No. 2, Fall/Winter 2012, 157-195.

Mukwege, Denis. "Dr. Mukwege Fights Back." http://kristof.blogs.nytimes.com/, accessed August 20, 2013.

Mumford, Lewis. The Culture of Cities. San Diego: Harcourt Brace \& Company, 1970.

Muschamp, Herbert. "Shaping a Monument to Memory." New York Times. Accessed September 15, 2013. http://www.nytimes.com/1993/04/11/arts/architecture-viewshaping-a-monument-to-memory.html?pagewanted $=$ all \&src=pm.

Myers-Feinstein, Margarete. "Re-imagining the Unimaginable: Theater, memory, and rehabilitation in the Displaced Persons Camps." In After the Holocaust: Challenging the Myth of Silence, edited by David Cesarani and Eric J. Sundquist. London and New York: Routledge, 2012.

Nathenson, Cary. "Chrismukkah as Happy Ending?-The Weihnukka Exhibition at the Jewish Museum Berlin as German-Jewish Integration Fantasy." Journal of Jewish Identities, January 2013, 6 (1). 
Neusner, Jacob. Death and Birth of Judaism: The Impact of Christianity, Secularism, and the Holocaust on Jewish Faith. New York: Basic Books, Inc., 1987.

Newhouse, Victoria. Art and the Power of Placement. New York: Monacelli Press, 2005.

---. “Is 'The Idea of a Museum' Possible Today?” Daedalus, Vol. 128, No. 3, American's Museums (Summer, 1999): 321-326.

Newton, Adam Zachary. Narrative Ethics. Cambridge, Massachusetts and London, England: Harvard University Press, 1995.

Nora, Pierre. "Between Memory and History: Les Lieux de Memoire." Representations 26 (1989): 7-24.

Novick, Peter. The Holocaust in American Life. Boston and New York: Houghton Mifflin Company, 1999.

Obama, Barack. Remarks at the United States Holocaust Memorial Museum on Preventing Mass Atrocities, Washington, D.C. April 23, 2012.

http://www.whitehouse.gov/the-press-office/2012/04/23/remarks-president-united-statesholocaust-memorial-museum.

Ochsner, Jeffrey Karl. "Understanding the Holocaust through the U.S. Holocaust Memorial Museum." Journal of Architectural Education, Vol. 48, No. 4 (May, 1995): 240-249.

Ofer, Dalia. "The Community and the Individual: The Different Narratives of Early and Late Testimonies and Their Significance for Historians." In Holocaust Historiography in Context: Emergence, Challenges, Polemics, \& Achievements, edited by David Bankier and Dan Michman. New York and Oxford: Berghahn Books, 2008.

---. "The Past That Does Not Pass: Israelis and Holocaust Memory." Israel Studies, Volume 14, Number 1, Spring 2009, 1-35.

---. "The Strength of Remembrance: Commemorating the Holocaust During the First Decade of Israel." Jewish Social Studies, Volume 6, Number 2, Winter 2000 (New Series): $24-55$.

---. "We Israelis Remember, But How? The Memory of the Holocaust and the Israeli Experience." Israel Studies, Volume 18, No. 2, Summer 2013, 70-85.

Olick, Jeffrey K., Vered Vinitzky Seroussi, and Daniel Levy. The Collective Memory Reader. Oxford: Oxford University Press, 2011.

---. "Collective Memory: The Two Cultures." Sociological Theory, Vol. 17, No. 3 (Nov., 1999): 333-348. 
---. Guilt and Defense: On the Legacies of National Socialism in Postwar Germany. Harvard University Press, 2010.

---. In the House of the Hangman: The Agonies of German Defeat, 1943-1949. University of Chicago Press, 2005.

---. The Politics of Regret: On Collective Memory and Historical Responsibility. Routledge, 2007.

Olick, Jeffrey and Joyce Robbins. 'Social Memory Studies: From 'Collective Memory' to the Historical Sociology of Mnemonic Practices." Annual Review of Sociology, Vol. 4 (1998): 105-140.

Olick, Jeffrey. States of Memory: Continuities, Conflicts, and Transformations in National Retrospection (Politics, History, and Culture). Duke University Press Books, 2003.

Ophir, Adi. "On Sanctifying the Holocaust: An Anti-Theological Treatise." In Impossible Images: Contemporary Art After the Holocaust, Shelley Hornstein, Laura Levitt, and Laurence J. Silberstein, eds., New York and London: New York University Press, 2003.

Orange, Jennifer A. and Jennifer J. Carter. "'It's Time to Pause and Reflect': Museums and Human Rights." Curator: The Museum Journal. Volume 55, Number 3 (July 2012): 259-266.

Ouroussoff, Nicolai. New York Times, "A Forest of Pillars, Recalling the Unimaginable," May 9, 2005.

Paine, Crispin. Religious Objects in Museums: Private Lives and Public Duties. London and New York: Bloomsbury, 2013.

Parry, Ross. Museums in a Digital Age. London: Routledge, 2010.

Pearce, Caroline. Contemporary Germany and the Nazi Legacy: Remembrance, Politics and the Dialectic of Normality. New York: Palgrave Macmillan, 2008.

Phillips, Kendall R. and G. Mitchell Reyes, eds. Global Memoryscapes: Contesting Remembrance in a Transnational Age. Tuscaloosa: University of Alabama Press, 2011.

Pinchevski, Amit. “Archive, Media, Trauma." In On Media Memory: Collective Memory in a New Media Age, eds. Motti Neiger, Oren Meyers, and Eyal Zandberg. Palgrave Macmillan: 2011.

Porat, Dina. "First Testimonies on the Holocaust: The Problematic Nature of Conveying and Absorbing them, and the Reaction in the Yishuv." In Holocaust Historiography in Context: Emergence, Challenges, Polemics, \& Achievements, edited by David Bankier and Dan Michman. New York and Oxford: Berghahn Books, 2008. 
Prell, Riv-Ellen. Fighting to Become Americans: Jews, Gender, and the Anxiety of Assimilation. Boston: Beacon Press, 1999.

Rabinowitz, Dorothy. New Lives: Survivors of the Holocaust Living in America. New York, New York: Alfred A. Knopf, 1976.

Rawlins, Kipi. "Educational Metamorphosis of the American Museum." Studies in Art Education, Vol. 20, No. 1 (1978): 4-17.

Ricouer, Paul. Memory, History, Forgetting. Translated by Kathleen Blamey \& David Pellauer. Chicago and London: Chicago University Press, 2004.

Robert, William. "Witnessing the Archive: In Mourning." In Religion, Violence, Memory, and Place, edited by Oren Baruch Stier and J. Shawn Landres. Bloomington and Indianapolis: University of Indiana Press, 2006.

Roberts, Lisa C. From Knowledge to Narrative: Education and the Changing Museum. Washington and London: Smithsonian Institution Press, 1997.

Rosen, Alan. The Wonder of Their Voices: The 1946 Holocaust Interviews of David Boder, Oxford University Press: 2010.

Rosenbaum, Alan S. Is the Holocaust Unique?: Perspectives on Comparative Genocide. Boulder, Colorado: Westview Press, 1996.

Rosenberg, Sheri P. "Genocide Is a Process, Not an Event." Genocide Studies and Prevention, Volume 7, Number 1, Spring 2012: 16-23.

Rosenfeld, Alvin H. ed. The End of the Holocaust. Bloomington and Indianapolis: Indiana University Press, 2011.

Rosenfeld, Gavriel D. Building After Auschwitz: Jewish Architecture and the Memory of the Holocaust. New Haven and London: Yale University Press, 2011.

---. "A Flawed Prophecy? Zakhor, the Memory Boom, and the Holocaust." Jewish Quarterly Review, Volume 97, Number 4 (Fall 2007): 508-520.

Rosenfeld, Gavriel D. and Asher Biemann, trans. "From Mussolini's Estate to Shoah Memorial: A Conversation with Luca Zevi, Architect of Rome's Holocaust Museum," accessed July 17, 2013, http://forward.com/articles/140533/from-mussolini-s-estate-toshoah-memorial.

Rosenfeld, Gavriel D. "A Looming Crash or a Soft Landing? Forecasting the Future of the Memory 'Industry." Fairfield University History Faculty Publications, Chicago: University of Chicago Press (2009): 122-158. 
---. "The Politics of Uniqueness: Reflections on the Recent Polemical Turn in Holocaust and Genocide Scholarship.” Holocaust and Genocide Studies, V13 N1 (Spring 1999): $28-61$.

Rossington, Michael and Anne Whitehead. Theories of Memory: A Reader. Baltimore: The Johns Hopkins University Press, 2007.

Roth, John K. "If God was silent, absent, dead, or nonexistent, what about philosophy and theology? Some aftereffects and aftershocks of the Holocaust." In After the Holocaust: Challenging the Myth of Silence, edited by David Cesarani and Eric J. Sundquist. London and New York: Routledge, 2012.

Rothberg, Michael. "Fractured Relations: The Multidirectional Holocaust Memory of Caryl Phillips." In After Testimony: The Ethics and Aesthetics of Holocaust Narrative for the Future, edited by Jakob Lothe, Susan Rubin Suleiman, and James Phelan, 331-349. Columbus, Ohio: Ohio State University Press, 2012.

Rothstein, Edward. "Holocaust Museums In Israel Evolve." New York Times, September 4, 2012.

Rubenstein, Richard L. After Auschwitz: Radical Theology and Contemporary Judaism. Indianapolis, New York, and Kansas City: The Bobbs-Merrill Company, Inc., 1966.

Ruffins, Faith Davis. "Revisiting the Old Plantation: Reparations, Reconciliation, and Museumizing American Slavery." In Museum Frictions: Public Cultures/Global Transformations, edited by Ivan Karp, Corinne A. Kratz, Lynn Szwaja, and Tomas Ybarra-Frausto. Durham and London: Duke University Press, 2006.

Sabini, John and Maury Silver. Moralities of Everyday Life. Oxford, England: Oxford University Press, 1982.

Sacks, Jonathan. Crisis and Covenant: Jewish thought after the Holocaust. Manchester and New York: Manchester University Press, 1992.

Saidel, Rochelle G. Never Too Late to Remember: The Politics Behind New York City's Holocaust Museum. New York and London: Holmes \& Meier, 1996.

de Saint-Cheron, Philippe. Evil and Exile. Notre Dame and London: University of Notre Dame Press, 1990.

Saltzman, Lisa. Anselm Kiefer and Art After Auschwitz, Cambridge, England: Cambridge University Press, 1999.

---. Making Memory Matter: Strategies of Remembrance in Contemporary Art, Chicago \& London: The University of Chicago Press, 2006.

Sandell, Richard. Museums, Society, Inequality, London and New York: Routledge, 2002. 
Sarna, Jonathan. American Judaism: A History. New Haven and London: Yale University Press, 2004.

Savage, Kirk. Monument Wars: Washington, D.C., the National Mall, and the Transformation of the Memorial Landscape. Berkeley, Los Angeles, and London: University of California Press, 2005.

Schein, Ada. "Everyone Can Hold a Pen': The Documentation Project in the DP Camps in Germany." In Holocaust Historiography in Context: Emergence, Challenges,

Polemics, \& Achievements, edited by David Bankier and Dan Michman. New York and Oxford: Berghahn Books, 2008.

Schemo, Diana Jean. "Holocaust Museum Hailed as Sacred Debt to Dead.” New York Times, April 23, 1993.

Schwarz, Jan. "A Library of Hope and Destruction: The Yiddish Book Series 'Dos poylishe yidntum' (Polish Jewry) 1946-1966." In Polin: Studies in Polish Jewry, Volume Twenty: Making Holocaust Memory, edited by Gabriel N. Finder, Natalia Aleksiun, Antony Polonsky, and Jan Schwarz. Oxford and Portland, Oregon: The Littman Library of Jewish Civiliation, 2008.

Segev, Tom. The Seventh Million: The Israelis and the Holocaust. New York, New York: Hill and Wang, 1993.

Shephard, Ben. The Long Road Home: The Aftermath of the Second World War. New York: Alfred A. Knopf, 2011.

Seldin, Ruth R., ed. American Jewish Yearbook. New York: American Jewish Committee and Philadelphia: The Jewish Publication Society, 1991.

Shapiro, Edward S. A Time For Healing: American Jewry Since World War II. Baltimore and London: Johns Hopkins University Press, 1992.

Silverman, Lois H. The Social Work of Museums. London and New York: Routledge, 2010 .

Sinefman, Susanna. "Formed and Forming: Contemporary Museum Architecture." Daedalus, Vol. 128, No. 3 (Summer 1999): 297-320.

Sandahl, Jette. "Disagreement Makes Us Strong?" Curator: The Museum Journal, Volume 55, Number 4 (October 2012): 467-468.

Staub, Michael E. Torn at the Roots: The Crisis of Jewish Liberalism in Postwar America. New York: Columbia University Press, 2002.

Stier, Oren Baruch. Committed to Memory: Cultural Mediations of the Holocaust. Amherst, MA: University of Massachusetts Press, 2003. 
---. "Different Trains: Holocaust Artifacts and the Ideologies of Remembrance." Holocaust and Genocide Studies 19.1 (2005): 81-106.

Stier, Oren Baruch. "Virtual Memories: Mediating the Holocaust at the Simon Wiesenthal Center's Beit Hashoah-Museum of Tolerance." Journal of the American Academy of Religion, Vol. 64, No. 4, Thematic Issue on "Religion and American Popular Culture" (Winter, 1996): 831- 851.

Sturken, Marita. Tangled Memories: The Vietnam War, the AIDS Epidemic, and the Politics of Remembering. Berkeley: University of California Press, 1997.

Swatos, Jr., William H. and Luigi Tomasi. From Medieval Pilgrimage to Religious Tourism. The Social and Cultural Economics of Piety. Westport, CT: Praeger, 2002.

Tanakh: The Holy Scriptures. Philadelphia and Jerusalem: The Jewish Publication Society, 1985.

Taylor, Mark C. Disfiguring: Art, Architecture, Religion. Chicago: University of Chicago Press, 1992.

Theriault, Henry C. "Against the Grain: Critical Reflections on the State and Future of Genocide Scholarship." Genocide Studies and Prevention, Volume 7, Number 1, (Spring 2012):123-144.

"The Architecture and Art of the United States Holocaust Memorial Museum." United States Holocaust Memorial Museum. Accessed September 15, 2013. http://www.ushmm.org/museum/a_and_a/.

"Developing A Public Early Warning System for Genocide and Mass Killing." United States Holocaust Memorial Museum. Accessed September 15, 2013. http://www.ushmm.org/genocide/analysis/details.php?content=2011-10-05

Van Alphen, Ernst. Caught by History: Holocaust Effects in Contemporary Art, Literature, and Theory. Stanford, California: Stanford University Press, 1997.

Van Gennep, Arnold. The Rites of Passage. Translated by Monika B. Vizedom and Gabrielle L. Caffee. Chicago: University of Chicago Press, 1960.

Vanhoozer, Kevin J. Cambridge Companion to Postmodern Theology. Cambridge: Cambridge University Press, 2003.

Vice, Sue. Representing the Holocaust. London, Portland, Oregon: Vallentine Mitchell, 2003.

Vidler, Anthony. "“Building in Empty Space:"” Daniel Libeskind's Museum of the Voice," in Daniel Libeskind: The Space of Encounter, 222-224. London: Thames \& Hudson Ltd, 2001. 
---. Warped Space. Art, Architecture, and Anxiety in Modern Culture. Cambridge, MA: MIT Press, 2000.

Vinciguerra, Thomas J., ed. with Elie Wiesel and Richard D. Heffner. Conversations with Elie Wiesel. New York: Schocken Books, 2001.

Wake, Caroline. "Regarding the Recording: The Viewer of Video Testimony, the Complexity of Copresence and the Possibility of Tertiary Witnessing." History \& Memory, Vol. 25, No. 1 (Spring/Summer 2013): 111-144.

Wallace, Mike. "Changing media, changing messages." Museum, Media, Message, Eilean Hooper-Greenhill, London and New York: Routledge, 1995.

Ward, Janet. "Monuments of Catastrophe. Holocaust Architecture in Washington and Berlin." In Berlin-Washington, 1800-2000. Capital Cities, Cultural Representation, and National Identities, edited by Andreas W. Daum and Christof Mauch. Cambridge: Cambridge University Press, 2005.

Weinberg, Jeshajahu. "Introduction." In The World Must Know: The History of the Holocaust as Told in the United States Holocaust Memorial Museum. Edited by Michael Berenbaum. Boston: Little, Brown, 1993.

Wiesel, Elie. After the Darkness: Reflections on the Holocaust. Schocken Books: 2002. ---. And the Sea Is Never Full: Memoirs, 1969-. Translated by Marion Wiesel. New York, NY: Schocken Books, 1999.

---. “Art and the Holocaust: Trivializing Memory.” New York Times. June 11, 1989.

Weissberg, Liliane. "Memory Confined." Cultural Memory and the Construction of Identity, eds. Dan Ben-Amos and Liliane Weissberg, Detroit: Wayne State University Press, 1999.

Weissman-Joselit, Jenna. The Wonders of America: Reinventing Jewish Culture, 18801950. New York: Henry Holt and Company: 1994.

Werthimer, Jack. "The Turbulent Sixties.” In The American Jewish Experience, edited by Jonathan Sarna. New York and London: Holmes \& Meier, 1986.

White, Hayden. Metahistory: The Historical Imagination in $19^{\text {th }}$ - Century Europe. Baltimore: Johns Hopkins Univeristy Press, 1973.

Whitfield, Stephen J. In Search of American Jewish Culture. Hanover and London: University Press of New England, 1999.

Wiesel, Elie. After the Darkness: Reflections on the Holocaust. Schocken Books: 2002. 
---. And the Sea Is Never Full: Memoirs, 1969-. Translated by Marion Wiesel. New York, NY: Schocken Books, 1999.

---. “Art and the Holocaust: Trivializing Memory." New York Times. June 11, 1989.

---. "Words from a Witness." Conservative Judaism Vol. 21, 9 (Spring 1967): 40-48.

Wieviorka, Annette. The Era of the Witness. Ithaca and London: Cornell University Press, 2006.

Williams, Paul. Memorial Museums: The Global Rush to Commemorate Atrocities. Oxford: Berg Publishers, 2007.

Wischnitzer, Rachel. Synagogue Architecture in the United States: History and Interpretation. Philadelphia: The Jewish Publication Society of America, 1955.

Wise, Michael Z. Capital Dilemma: Germany's Search for a New Architecture of Democracy. New York: Princeton Architectural Press, 1998.

Wolterstorff, Nicholas. Art in Action: Toward a Christian Perspective. Grand Rapids, Michigan: William B. Eerdmans Publishing Company, 1980.

Yerushalmi, Yosef Hayim. Zahkor: Jewish History and Jewish Memory. Seattle: University of Washington Press, 1982.

Young, James E. At Memory's Edge: After-Images of the Holocaust in Contemporary Art and Architecture. New Haven and London: Yale University Press, 2000.

---. "Daniel Libeskind's Jewish Museum in Berlin: The Uncanny Arts of Memorial Architecture.” Jewish Social Studies Vol. 6 No. 2, (Winter 2000): 1-23.

---. The Texture of Memory: Holocaust Memorials and Meaning. New Haven and London: Yale University Press, 1993.

Zelizer, Barbie. Remembering to Forget: Holocaust Memory Through the Camera's Eye. Chicago: University of Chicago Press, 1998.

Zertal, Idith. From Catastrophe to Power: Holocaust Survivors and the Emergence of Israel. Berkeley, Los Angeles, and London: University of California Press, 1998. 